San Jose State University

SJSU ScholarWorks

Master's Theses

Master's Theses and Graduate Research

Fall 2016

\title{
Zircon Geochemical and Isotopic Constraints on the Evolution of the Mount Givens Pluton, Central Sierra Nevada Batholith
}

Callie Sendek

San Jose State University

Follow this and additional works at: https://scholarworks.sjsu.edu/etd_theses

\section{Recommended Citation}

Sendek, Callie, "Zircon Geochemical and Isotopic Constraints on the Evolution of the Mount Givens Pluton, Central Sierra Nevada Batholith" (2016). Master's Theses. 4777.

DOI: https://doi.org/10.31979/etd.qtj4-39rc

https://scholarworks.sjsu.edu/etd_theses/4777

This Thesis is brought to you for free and open access by the Master's Theses and Graduate Research at SJSU ScholarWorks. It has been accepted for inclusion in Master's Theses by an authorized administrator of SJSU ScholarWorks. For more information, please contact scholarworks@sjsu.edu. 


\author{
A Thesis \\ Presented to \\ The Faculty of the Department of Geology \\ San José State University \\ In Partial Fulfillment \\ of the Requirements for the Degree \\ Master of Science
}

by

Callie Sendek

December 2016 
(C) 2016

Callie Sendek

ALL RIGHTS RESERVED 
The Designated Thesis Committee Approves the Thesis Titled

ZIRCON GEOCHEMICAL AND ISOTOPIC CONSTRAINTS ON THE EVOLUTION OF THE MOUNT GIVENS PLUTON, CENTRAL SIERRA NEVADA BATHOLITH

\author{
by \\ Callie Sendek \\ APPROVED FOR THE DEPARTMENT OF GEOLOGY
}

SAN JOSÉ STATE UNIVERSITY

December 2016

$\begin{array}{ll}\text { Jonathan Miller, Ph.D. } & \text { Department of Geology } \\ \text { Robert Miller, Ph.D. } & \text { Department of Geology } \\ \text { Jade Star Lackey, Ph.D. } & \begin{array}{l}\text { Geology Department, Pomona } \\ \text { College }\end{array}\end{array}$ 


\section{ABSTRACT \\ ZIRCON GEOCHEMICAL AND ISOTOPIC CONSTRAINTS ON THE EVOLUTION OF THE MOUNT GIVENS PLUTON, CENTRAL SIERRA NEVADA BATHOLITH \\ by Callie Sendek}

The Late Cretaceous Mount Givens pluton, located in the central Sierra Nevada batholith, is noteworthy for its large size $\left(\sim 1400 \mathrm{~km}^{2}\right)$ and relative compositional and textural homogeneity. The pluton is characterized by a $30 \mathrm{~km}$ wide, ellipse-shaped northern lobe (ca. 98-91 Ma) that connects with a long mass (ca. 95-91 Ma) about $15 \mathrm{~km}$ wide and extends $50 \mathrm{~km} \mathrm{SE}$. Zircon trace elements and $\mathrm{d} 18 \mathrm{O}$ and eHf from a sample suite representative of the observable petrologic diversity of the pluton document significant heterogeneities. All zircons have high Ti-in-zircon model temperatures (850$1000{ }^{\circ} \mathrm{C}$ ), pronounced negative Eu anomalies, and concave down MREE and HREE patterns, indicating initial melts were undersaturated in zircon and that zircon growth occurred during ascent or emplacement of Mount Givens magmas. Zircon trace elements record appreciable variation, and suggest that crystal transfer was ongoing throughout pluton growth. Significant variations in $\mathrm{O}$ and Hf isotopes require mixing of multiple, isotopically distinct sources. Longitudinal variation in both systems suggests increasing mantle contributions in the eastern portion of the pluton. A clear decrease in isotopic variability at all scales in post-95 Ma samples indicates that later magmas were more thoroughly mixed prior to emplacement. This increase in zircon isotopic homogeneity paired with the narrow timespan of intrusion hints that the inner portion of the northern lobe may have existed as a large melt reservoir. 


\section{ACKNOWLEDGMENTS}

I would first and foremost like to thank my thesis advisor and mentor Dr. Jonathan Miller. During my time at San Jose State University he has continuously gone out of his way to provide me with opportunities to advance my scientific career. I could not have made it through all of the challenges posed by this work without his consistent guidance and assurance. I would also like to thank my committee members Dr. Bob Miller and Dr. Jade Star Lackey. Bob has taught me nearly everything I know about the structural geology of plutons, and has undoubtedly made me a better field geologist. Jade Star took me on my first trip to Yosemite, and opened my eyes to the wonders of the Sierra Nevada batholith and zircons. I am so grateful to have received input from such knowledgeable and enthusiastic scientists.

This research would have been impossible without the assistance of staff and faculty at the labs where analysis took place. I would like to thank Jade Star Lackey and Jonathan Harris for assistance with XRF analyses at Pomona College. Thank you to Matt Cobel, Jorge Vasquez, and Marsha Lidzbarski for their help with mount preparation and SHRIMP analysis at the USGS-Stanford SHRIMP analytical facility. Thank you to John Valley and Kouki Kitajima at University of Wisconsin Madison SIMS lab. Thank you to Gareth Davies and Bas Van der Wagt at VU Amsterdam, and to Robyn van der Velde who hosted me during my stay in the city. This research was funded by NSF Grant \#0948679.

There are many individuals at San José State University who have provided me with technical and emotional support throughout this process. I would like to thank 
Alphonse Odisho, Ginny Smith, and Leslie Blum for their expertise, help, and friendship. I would like to thank my field assistants, Kaai Johnson and Wes Dugan, for their help during one of the most intimidating portions of this project. Thank you to my lab assistant Dustin Williams, whose calm support was incredibly helpful during the difficulties encountered during analytical work. I would also like to thank all of the friends I have made at San Jose State who have always been around to listen and provide advice through my education here. I cannot image getting through this process without them. Finally, I would like to thank my family for their continual support of my education and well-being. 


\section{TABLE OF CONTENTS}

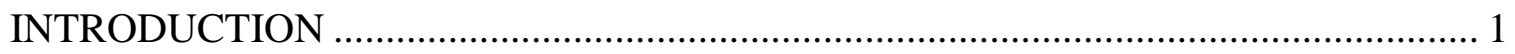

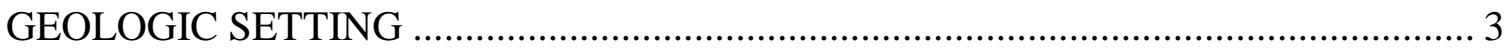

GEOCHEMICAL AND ISOTOPIC ANALYSIS OF ZIRCON …………………......... 10

Lutetium-Hafnium Isotopes in Zircon ............................................................. 10

Oxygen Isotopes in Zircon............................................................................. 12

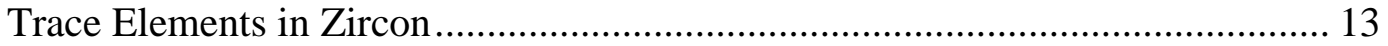

Zircon Saturation Thermometer.................................................................... 13

$\mathrm{Ti}$ in Zircon Thermometry .............................................................................. 14

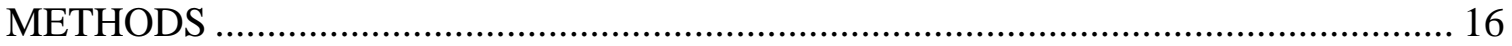

Zircon Separation and Imaging ......................................................................... 16

Whole Rock Geochemistry …………............................................................... 18

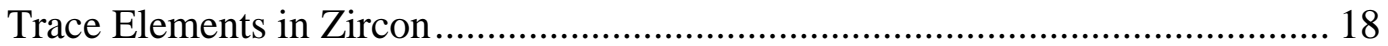

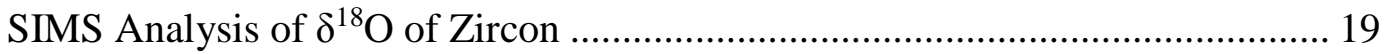

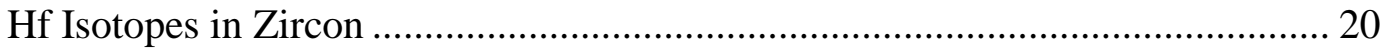

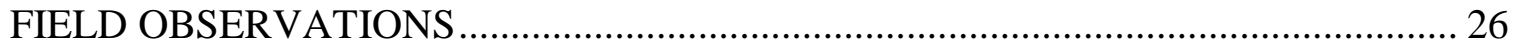

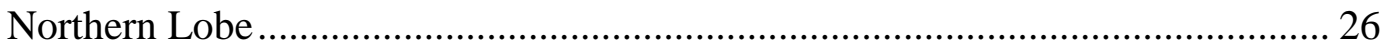

Equigranular Granodiorite ………………………………………...... 27

Porphyritic Granodiorite ....................................................................... 27

Granodiorite of Cow Meadow …………………………...................... 28

Aplite of Jackass Rock........................................................................ 29

Enclaves of the Northern Lobe ............................................................. 29

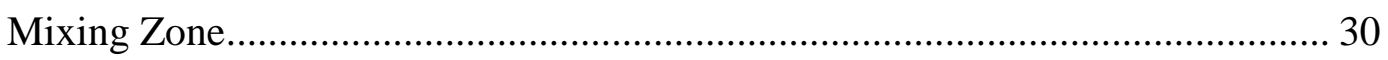

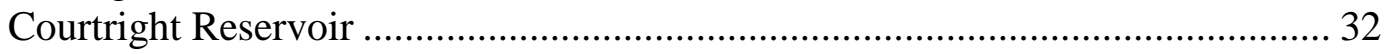

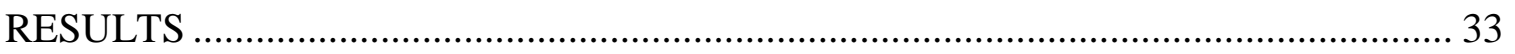

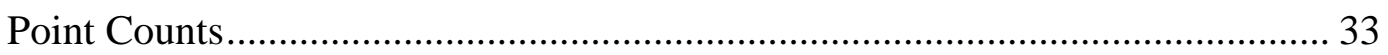

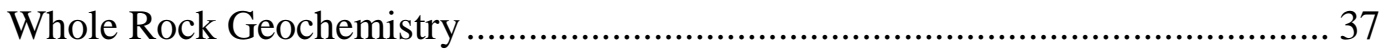

Zircon Thermometry ……………………………......................................... 37

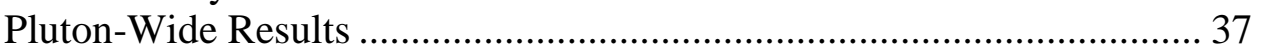

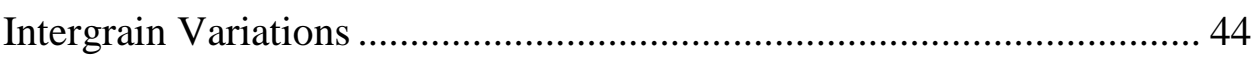

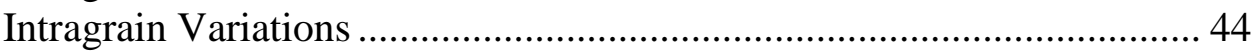

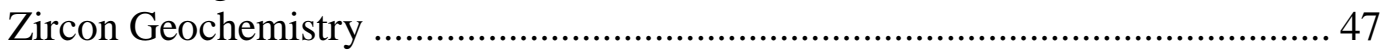


Intercrystalline Variations........................................................ 55

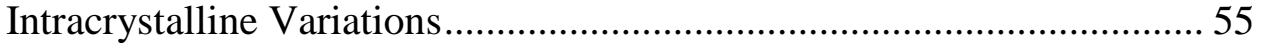

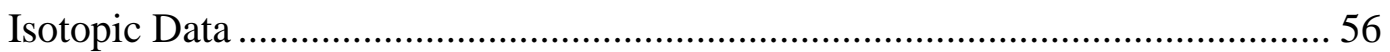

Longitudinal Variation.................................................................. 59

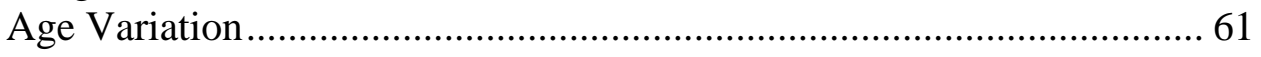

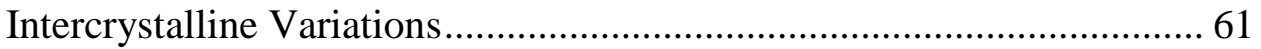

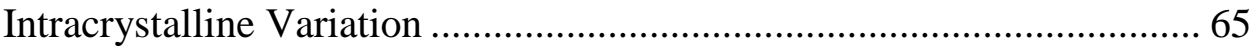

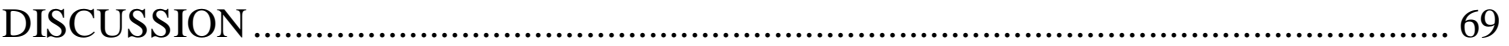

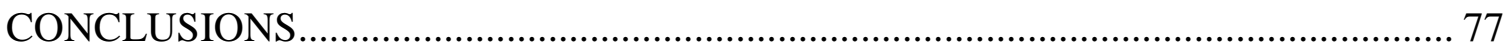

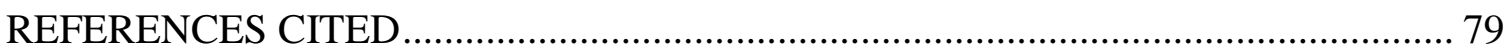

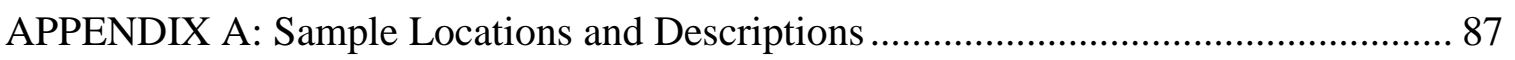

APPENDIX B: Cathodoluminescence Images with Indexed Analysis Spots ................. 88

APPENDIX C: Cathodoluminescence Images with $\delta^{18} \mathrm{O}, \varepsilon \mathrm{Hf}$, and Trace Element

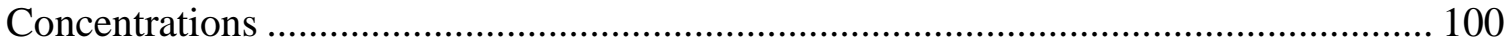

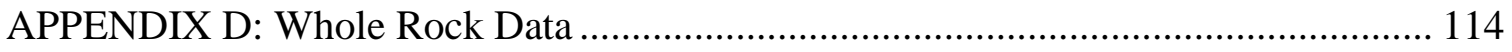

APPENDIX E: SHRIMP Trace Element in Zircon Data............................................ 117

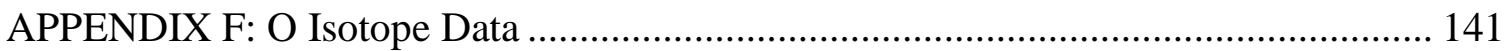

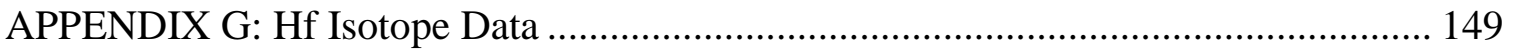

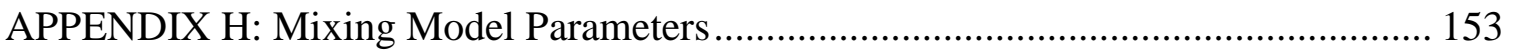




\section{LIST OF TABLES}

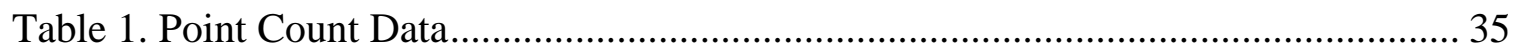




\section{LIST OF FIGURES}

Figure 1. Generalized map of the Sierra Nevada batholith......................................... 4

Figure 2. Geologic map of Mount Givens pluton and surrounding intrusions .................. 6

Figure 3. Map of U-Pb CA-ID-TIMS ages within the Mount Givens pluton.................... 9

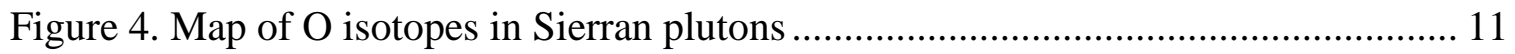

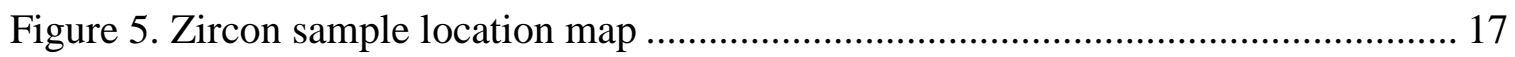

Figure 6. External error plot for 91500 zircon standard ......................................... 20

Figure 7. External error plot for JG1 zircon standard .......................................... 22

Figure 8. External error plot for R33 zircon standard........................................... 23

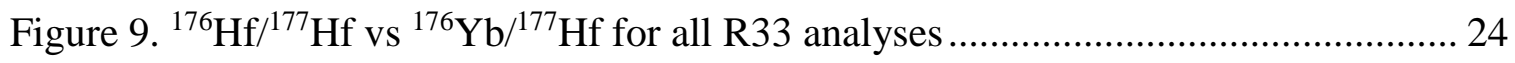

Figure 10. R33 Standard measurements for entire Hf analytical session ...................... 25

Figure 11. External error plot for Plešovice zircon standard. .................................... 26

Figure 12. Representative rock textures in the northern lobe .................................. 28

Figure 13. Magmatic interactions in central mixing zone ...................................... 31

Figure 14. Mafic enclaves and schlieren near Courtright Reservoir ............................. 33

Figure 15. QAP diagram showing modal mineralogy of Mount Givens samples ........... 36

Figure 16. Whole rock major element geochemistry …...................................... 38

Figure 17. Whole rock trace element geochemistry …............................................. 39

Figure 18. Chondrite normalized whole rock REE plots........................................ 40

Figure 19. Histogram of calculated Ti-in-zircon temperatures for entire sample suite.... 41

Figure 20. Ti-in-zircon $\left(\mathrm{T}_{\mathrm{tiz}}\right)$ temperature profiles for different rock types................... 42

Figure 21. Schematic zircon temperature profile across northern lobe ........................ 43

Figure 22. Ti-in-zircon temperature measurements for porphyritic samples. ................ 45 
Figure 23. Ti-in-zircon temperature measurements for equigranular samples............... 46

Figure 24. Ti-in-zircon temperature measurements for compositional outliers ............... 46

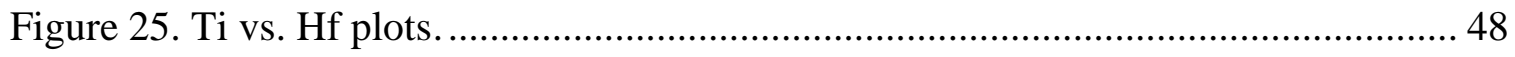

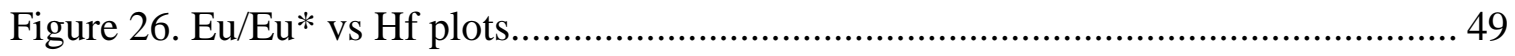

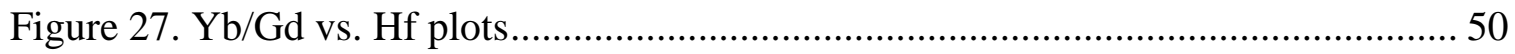

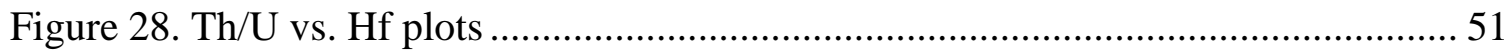

Figure 29. REE in zircon plots separated by rock type .......................................... 52

Figure 30. Rank order plot of zircon Hf concentration.......................................... 52

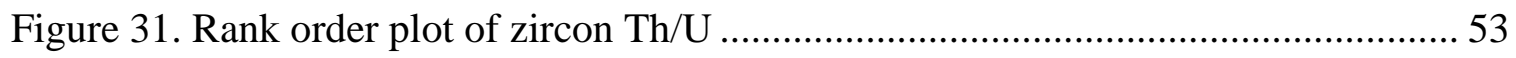

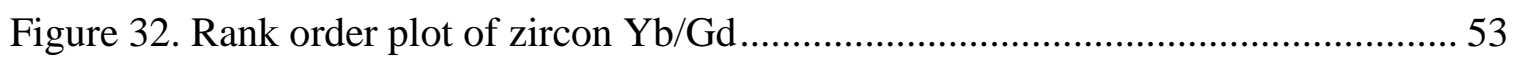

Figure 33. Rank order plot of calculated Ti-in-zircon temperatures ............................. 54

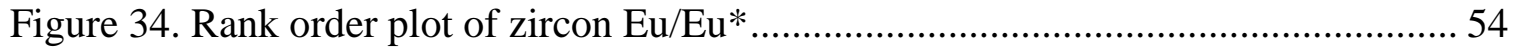

Figure 35. Intracrystalline variation in zircon trace elements.................................. 56

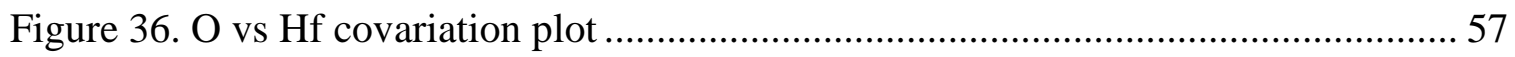

Figure 37. Variation of isotopes with bulk rock composition .................................... 58

Figure 38. Variation of isotopes along Panthalassan-North American boundary ........... 60

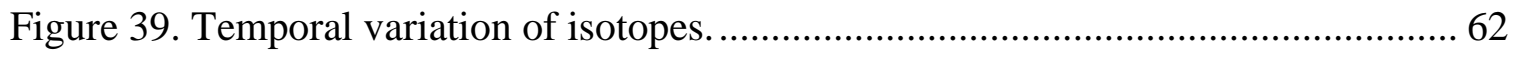

Figure 40. Covariant $\delta^{18} \mathrm{O}$ and $\varepsilon H f$ plot showing isotopic differences in pre- and post-95

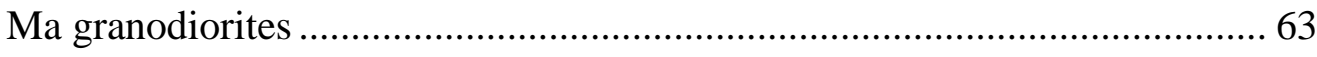

Figure 41. Variation of isotopes across Panthalassan-North American boundary,

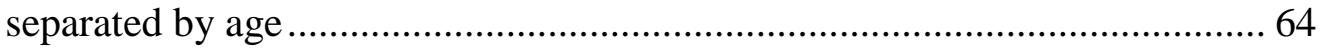

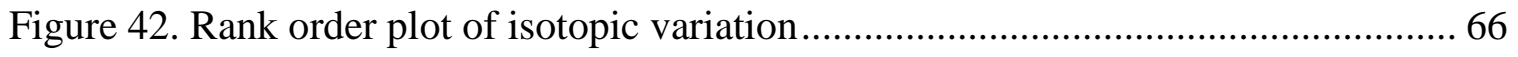

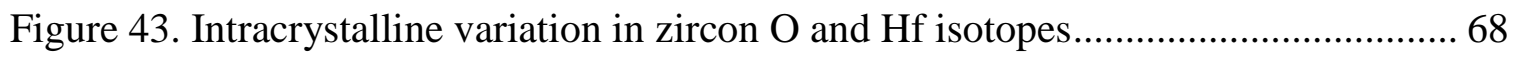

Figure 44. Mixing model for zircon isotopic compositions of Mount Givens samples....74 


\section{INTRODUCTION}

Magmatic arcs are important recorders of crustal growth, and large, silicic arc plutons have been extensively studied to understand the complex processes of magma generation, transport, emplacement, and magmatic processing at convergent margins (Bateman and Nokleberg; 1978; Kistler et al., 1986; Sawka, 1988; Hill, 1988; Bateman, 1992; Coleman et al., 1995; Tobisch et al., 1995; Paterson et al., 1996; Barth et al., 1997; Matzel et al., 2006; Paterson et al., 2011; Lackey et al., 2012). Early models of these plutons as large magma chambers and closed system fractional crystallization (e.g. Buddington 1959; Bateman and Chappell, 1979; Petford et al., 2000) have largely been replaced by ones that involve incremental emplacement by injection of multiple batches of magma into the crust (Brown and McClelland, 2000; Miller and Paterson, 2001; Mahan et al., 2003; Glazner et al., 2004; Žák and Paterson, 2005). This shift in understanding was largely brought about by the wide spread of zircon ages (hundreds of ka to tens of Ma) obtained for individual plutons by high precision $\mathrm{U}-\mathrm{Pb}$ thermal ionization mass spectrometry (TIMS) dating (Coleman et al., 2004; Matzel et al., 2006; Memeti et al., 2010; Davis et al., 2012; Frazer et al., 2014).

Although generally accepted, several aspects of the incremental emplacement model are still unclear. Vigorous debate is ongoing concerning the size of individual magma batches and where they acquire their fundamental chemical and petrologic characteristics. Some workers suggest that plutons grow by sheet-like intrusion of small pulses, which cool rapidly upon emplacement (Mahan et al., 2003; Glazner et al., 2004; Cruden et al., 2005; Bartley et al., 2006; Matzel et al., 2006). In this model, thermal 
constraints dictate that each small magma batch acts essentially as a closed system. Any variations in geochemical and isotopic composition in the pluton must therefore be attributed to changes in source material, rather than to interaction with other magmas during transport and/or emplacement, or in mid-shallow crustal arc magma chambers. In contrast, field evidence of magma mixing and uniform ages across volumetrically large units within some of the large intrusive suites have led others to argue that enough heat is present in the system to allow for interaction of disparate magmas at the site of emplacement (Harper et al., 2005; Hirt, 2007; Burgess and Miller, 2008; Economos et al., 2010; Memeti et al., 2010; Lackey et al., 2012). In this model, mid-crustal magma mixing and fractional crystallization can account for observed petrologic, geochemical and isotopic trends.

The accessory mineral zircon provides an excellent tool to investigate fundamental questions about magma genesis and evolution during pluton growth. Zircon is a robust recorder of its magmatic environment during crystallization, including temperature, geochemical, and isotopic information. Furthermore, the mineral's physiochemical resilience (Watson, 1996; Hawkesworth and Kemp, 2006) and the slow diffusion rates of important elements within its crystal lattice (Cherniak, 1995; Watson and Cherniak, 1995) allow zircon to preserve primary magmatic signatures even after being subjected to extreme thermal conditions (Page et al., 2007). Examining variation in zircon trace element and isotopic geochemistry across a pluton, within an individual sample, and within individual crystals (e.g. Claiborne et al., 2010) allows a better understanding of the scale of magma homogeneity, and the nature of magma mixing and 
interactions. When paired with age data, this information can produce a detailed record of changing magmatic conditions, and can clarify the extent of interaction between distinct magmas.

The Sierra Nevada batholith provides an excellent record of magmatic arc development in Mesozoic North America (Bateman, 1992; Ducea, 2001). This study aims to use the geochemical and isotopic information recorded in zircon to examine the magmatic history of the Mount Givens granodiorite, in the Central Sierra Nevada batholith. The Mount Givens pluton has been recognized for its relative petrologic homogeneity despite is large size (Bateman and Nokleberg, 1978; Bateman, 1992). By analyzing a sample suite representative of the observable petrologic diversity of the pluton, zircon data will demonstrate if this apparent lack of variability also applies to the geochemical and isotopic signatures of the magma. Measurable variations, paired with age data, will be used to assess how magmatic conditions changed over time, and to evaluate the implications for incremental emplacement of the Mount Givens pluton.

\section{GEOLOGIC SETTING}

The Sierra Nevada batholith (Fig. 1) was formed during Mesozoic subduction of the Farallon plate beneath the western margin of the North American continent (e.g. Hamilton, 1969; Kistler and Peterman, 1973; Bateman, 1974; 1992). In the Late Cretaceous, several large-volume intrusions were emplaced in the area now forming the crest of the Sierra Nevada at the peak of a large magmatic 'flare-up' (Coleman and Glazner, 1997; Ducea, 2001; DeCelles et al. 2009). Most of the plutons emplaced during this magmatic event exhibit compositional zonation, with inner units becoming 
progressively more felsic and porphyritic (Bateman, 1992). Although originally viewed as having formed via fractional crystallization of large magma chambers, more recent zircon $\mathrm{U}-\mathrm{Pb}$ geochronology has demonstrated evidence for incremental emplacement over periods of up to ten million years (Coleman et al., 2004; Memeti et al., 2011; Davis et al., 2012).

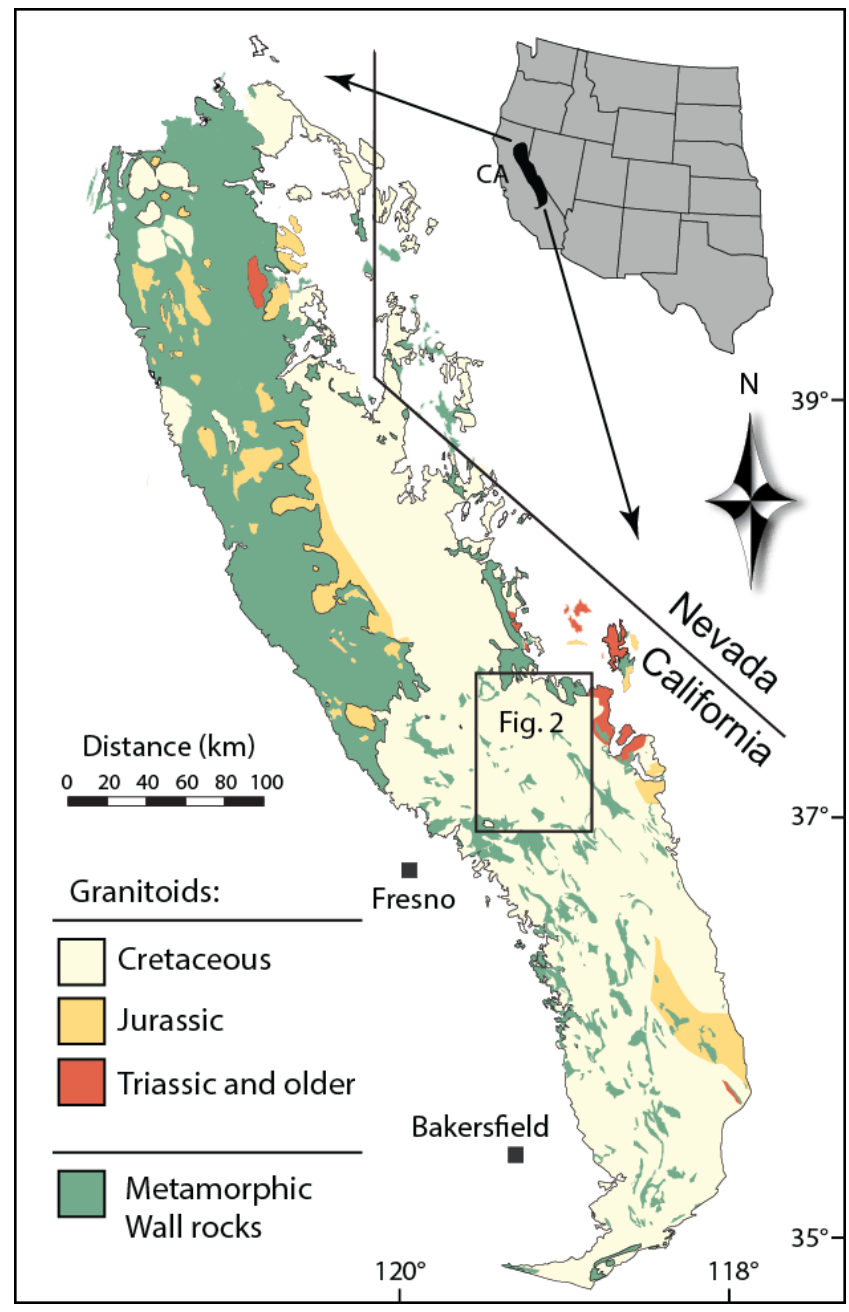

Figure 1. Generalized map of the Sierra Nevada batholith. Green represents metamorphic wall rock, and colors represent ages of granitoid rocks. Rectangle marks the area surrounding the Mount Givens pluton shown in Figure 2. Modified from Lackey et al. (2008). 
The Mount Givens pluton lies in the central Sierra Nevada Mountains (Fig. 1), where it intrudes the 106 to 97 Ma Shaver Lake intrusive suite to the west, and is separated from the Cretaceous John Muir intrusive suite to the east by the Goddard Pendant (Fig. 2). It is comparable in size to the zoned intrusive suites of the Sierra Crest, stretching $80 \mathrm{~km}$ in a northwest-southeast orientation, with an average width of $15 \mathrm{~km}$. The northern portion of the Mount Givens pluton is a 30-km-wide, bulbous lobe that contains the majority of the pluton's petrologic diversity (Bateman and Nokleberg, 1978). Aluminum-in-hornblende thermobarometric data suggest the pluton cooled at $3.3 \pm 0.3$ kbar ( 11-13 km) (Ague and Brimhall, 1988). Paleomagnetic data indicate a postcooling tilt of $10^{\circ}$ about an axis parallel to regional fabrics $\left(\sim 320^{\circ}\right.$; Gilder and McNulty, 1999).

The northern lobe can be divided into four main phases: equigranular, porphyritic, the granodiorite of Cow Meadow, and the aplite of Jackass Rock. As with the zoned intrusive suites of the Sierra Crest, there are broad-scale mafic to felsic and equigranular to porphyritic gradations moving inwards (Bateman and Nokleberg, 1978). This pattern is interrupted by the granodiorite of Cow Meadow, a horseshoe shaped exposure of equigranular, hornblende-biotite granodiorite within the more felsic, porphyritic unit. The external contact of the granodiorite of Cow Meadow has been mapped as intrusive, while the inner one is generally described as gradational (Bateman and Nokleberg 1978; McNulty et al., 2000). The southern portion of the Mount Givens pluton has been mapped as equigranular granodiorite, with the exception of a tongue of porphyritic 
material extending from the north, and several small aplite bodies near Courtright Reservoir (Fig. 2) (Bateman and Nokleberg, 1978; Bateman, 1992; McNulty et al., 2000).

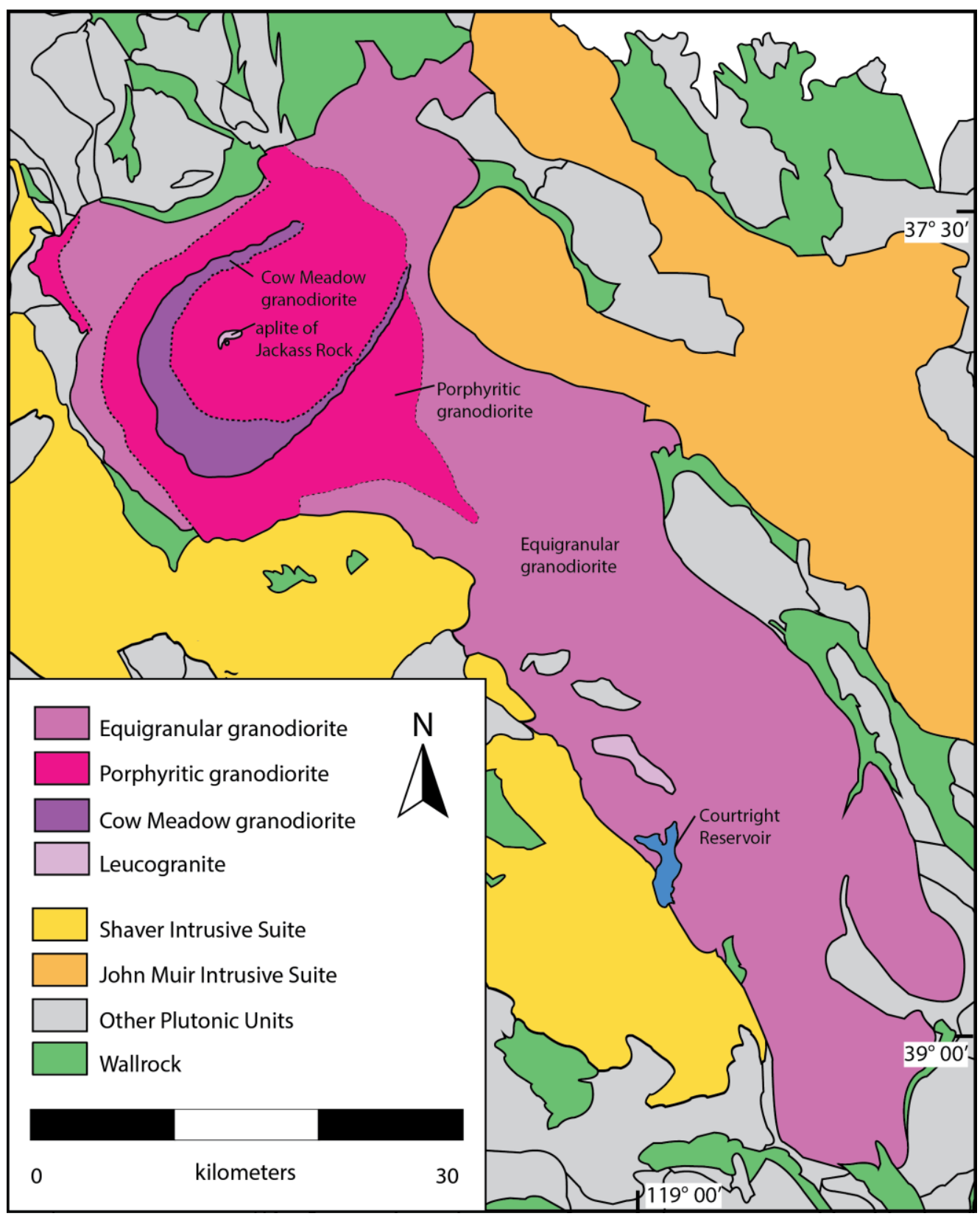

Figure 2. Geologic map of Mount Givens pluton and surrounding intrusions. Modified from Frazer et al. (2014). 
Early field and petrologic studies of the pluton noted the compositional and textural similarities between the northern lobe of Mount Givens and the zoned intrusive suites of the Sierra Crest. Petrographic and geochemical analysis of a sample transect through the northern lobe documented decreases in abundance and size of mafic minerals moving inwards, complimented by an increase in abundance and size of potassium feldspar and quartz (Bateman and Nokleberg, 1978). The trends all reverse at the contact with the Cow Meadow granodiorite, but continue moving inwards from there. Bateman and Nokleberg (1978) use this pattern as evidence of solidification of the Mount Givens granodiorite from a large magma body by fractional crystallization. The two aplitic units in the northern lobe and to the south were proposed as cooling centers that were the final felsic products of crystallization. Bateman (1992) explained the alternation of textural phases by folding of the pluton during expansion after emplacement of a stratified chamber with the megacrystic phase overlying the equigranular rocks.

Using a combination of magmatic foliation and anisotropy of magnetic susceptibility data from throughout the pluton, McNulty et al. (2000) proposed a multistage intrusion model. Their model divided the pluton into three "chambers" (northern, central, and southern), which were fed by north-south feeder dikes. Relatively short estimates of emplacement times were calculated based on floor down-drop as the hypothesized emplacement mechanism (McNulty et al., 2000; Petford et al., 2000). According to McNulty et al. (2000), initial voluminous magmatism produced the equigranular phase, which formed the southern chamber, and part of the central and northern chambers. Subsequent magmatism led to underplating of the megacrystic phase 
in the northern lobe, and lateral flow from the lobe into the central chamber. The granodiorite of Cow Meadow was a product of renewed magmatism that caused expansion and doming in the northern lobe. It ascended to its current location during a ring fracturing event that also juxtaposed the equigranular and megacrystic phases at the current level of exposure.

Recent $\mathrm{U}-\mathrm{Pb}$ chemical abrasion isotope dilution thermal ionization mass spectrometry (CA-ID-TIMS) dates from the Mount Givens pluton span over 7 million years, from $97.92 \pm 0.06$ to $90.87 \pm 0.05$ Ma (Fig. 3; Frazer et al., 2014). These dates show little overlap with previous multigrain $\mathrm{U}-\mathrm{Pb}$ ages that gave a range of $88-93 \mathrm{Ma}$ (Stern et al., 1981; Tobisch et al., 1993). This inconsistency may suggest an even longer period of pluton assembly, or may be due to $\mathrm{Pb}$ loss problems in earlier analyses that did not employ chemical abrasion (Frazer et al., 2014). The age spread for individual phases precludes rapid emplacement of each in discrete magmatic pulses, contradicting the emplacement scenario suggested by McNulty et al. (2000). Instead the northern lobe follows a normal younging inward pattern. Frazer et al. (2014) suggest that this may be due to "magmatic cycling", with exterior equigranular units cooling rapidly after emplacement into low-temperature host rock, and porphyritic textures in the core of the lobe forming during prolonged residence near the solidus.

The vast majority of the Mount Givens pluton lies directly to the east of the Panthalassan-North American boundary, a proposed major lithospheric suture dividing the North American crust to the east and accreted oceanic terranes to the west (Fig. 4). The boundary was originally proposed by Kistler (1990) on the basis of roof pendant 


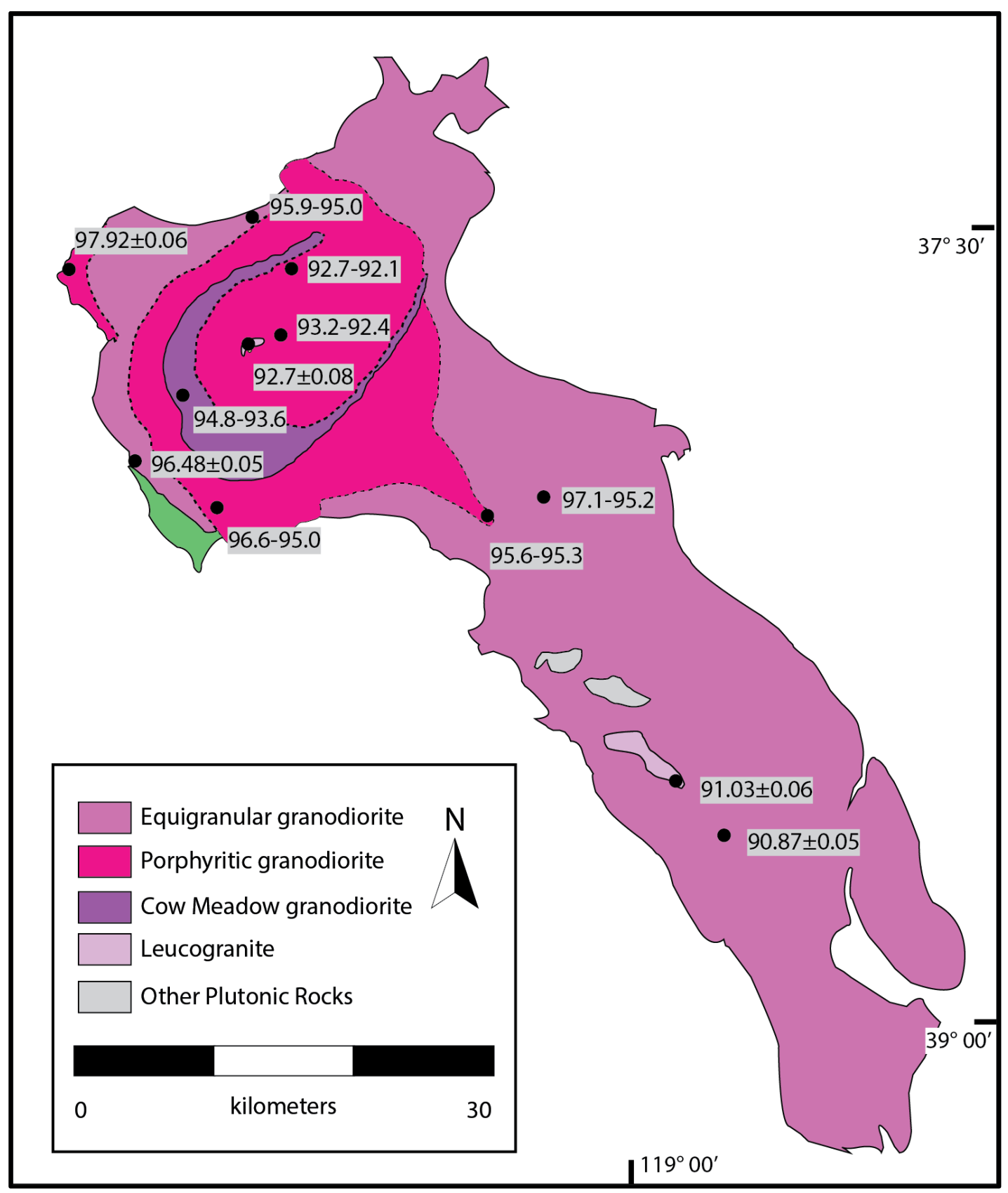

Figure 3. Map of U-Pb CA-ID-TIMS ages within the Mount Givens pluton. Listed ages are based on the interpretations of Frazer et al. (2014). Modified from Frazer et al. (2014). 
lithologies and the geochemical and whole rock $\mathrm{Sr}$ and $\mathrm{O}$ isotopic characteristics of intruded plutons. It has since been shifted eastward by Lackey et al. (2008) with the addition of zircon $\delta^{18} \mathrm{O}$ data (Fig. 4). Consistent isotopic ratios across compositionally variable suites suggest that limited crustal recycling was involved in the magmatism of the Sierra Crest plutons (Coleman and Glazner, 1997; Wenner and Colemen, 2004). Exceptions, including the Johnson Porphyry of the Tuolumne intrusive suite, fall on mixing curves between a mantle endmember and Proterozoic crust. A $1 \%$ increase in $\delta^{18} \mathrm{O}$ on the western margin of the Mount Givens pluton may suggest a crustal control on $\delta^{18} \mathrm{O}$, with western magmas showing increasing incorporation of the more highly altered Panthalassan lithosphere (Lackey et al., 2008).

\section{GEOCHEMICAL AND ISOTOPIC ANALYSIS OF ZIRCON}

\section{Lutetium-Hafnium Isotopes in Zircon}

Radiogenic ${ }^{176} \mathrm{Hf}$ is formed from the beta decay of ${ }^{176} \mathrm{Lu}$, and has a half-life of approximately 37 billion years. Hf is more incompatible than Lu during partial melting in the mantle, and is concentrated in the crust. Over time, this leads to relatively radiogenic ${ }^{176} \mathrm{Hf} /{ }^{177} \mathrm{Hf}$ ratios in the depleted mantle compared with continental crust, which generally has unradiogenic ratios, owing to low time-integrated $\mathrm{Lu} / \mathrm{Hf} .{ }^{176} \mathrm{Hf} /{ }^{177} \mathrm{Hf}$ ratios are commonly reported as a deviation from the chondritic uniform reservoir (CHUR) in epsilon units (parts per ten thousand). The Lu-Hf system is particularly useful in zircon because of the high compatibility of Hf relative to Lu in the crystal 


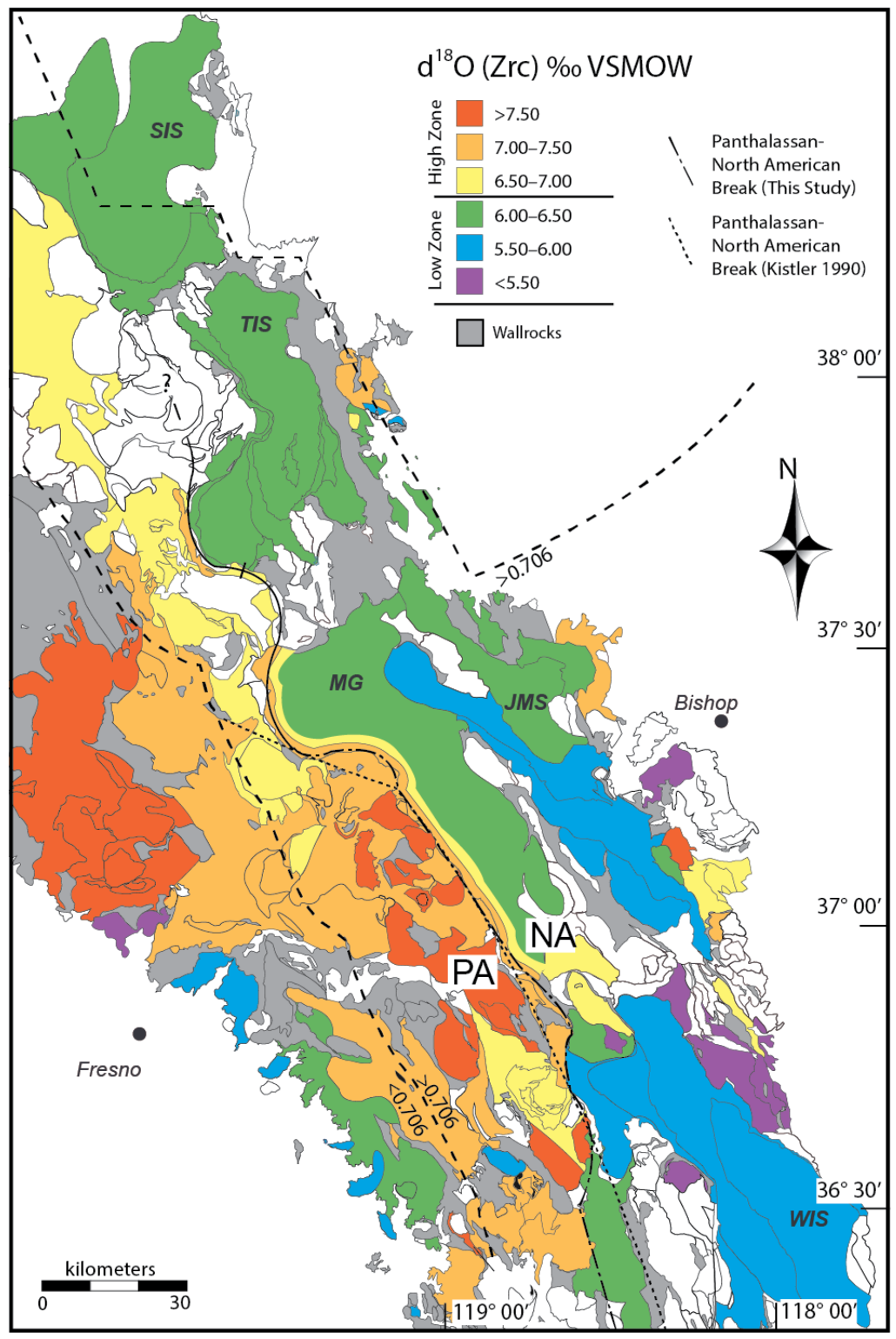

Figure 4. Map of $\mathrm{O}$ isotopes in Sierran plutons. Also included are the $\mathrm{Sr}_{\mathrm{i}} 706$ line and proposed locations of the Panthalassan-North American lithospheric boundary from Lackey et al. (2008) and Kistler (1990). JMS- John Muir intrusive suite; MG- Mount Givens pluton; NA- North American lithosphere; PA- Panthalassan lithosphere; SISSonora Pass intrusive suite; TIS- Tuolumne intrusive suite; WIS- Whitney intrusive suite. Modified from Lackey et al. (2008). 
lattice. Thus, radiogenic Hf accumulation due to in situ parental decay is negligible, and ${ }^{176} \mathrm{Hf} /{ }^{177} \mathrm{Hf}$ ratios in zircon reflect those of the parental magma (Kinny and Maas, 2003; Hawkesworth and Kemp, 2006). Because radiogenic isotopes decay with time, there is inherent ambiguity when interpreting epsilon values. For example, a low $\varepsilon H f$ magma could represent either mixing of a mantle melt with unradiogenic crustal material, or melting of mantle derived material that had aged in the crust (Hawkesworth and Kemp, 2006). The extent of the involvement of crustal material can be evaluated independently by $\mathrm{O}$ isotope measurements.

\section{Oxygen Isotopes in Zircon}

Stable O isotopes undergo mass fractionation, and, like Hf isotopes, can be used to examine possible magmatic source components. The ratio between the two most common isotopes of $\mathrm{O}$ is commonly expressed in delta notation, calculated as the deviation from ${ }^{18} \mathrm{O} /{ }^{16} \mathrm{O}$ of Vienna Standard Mean Ocean Water (VSMOW) multiplied by a thousand, and reported in parts per mil (Sharp, 2007). Zircons crystallized from the mantle have spatially and temporally consistent $\delta^{18} \mathrm{O}$ values of $5.3 \pm 0.3 \%$ (Valley, 2003). Near surface, low temperature water-rock interactions generally increase $\delta^{18} \mathrm{O}$ in rocks. More rarely, high temperature interactions with meteoric water decrease rock $\delta^{18} \mathrm{O}$ (Valley et al., 2005). Oxygen diffusion in zircon is sufficiently slow to retain magmatic $\delta^{18} \mathrm{O}$ signatures during subjection to surficial weathering and metamorphism (Watson and Cherniak, 1995; Valley, 2003). Therefore, zircons with $\delta^{18} \mathrm{O}$ values differing from those of the mantle can be assumed to have crystallized from a magma that was derived from, or had assimilated, crustal material. This record of surface alteration is often not present 
in the radiogenic record because the timescales are too short for partitioning of parent and daughter (Valley et al., 2005; Hawkesworth and Kemp, 2007).

\section{Trace Elements in Zircon}

The trace element concentrations in a melt are strongly affected by the processes of melt formation, mixing, and crystallization. Rare earth element (REE) behavior in silicic systems is primarily controlled by minor phases such as garnet, titanite, hornblende, and apatite. Because ionic radius decreases with increasing atomic number, heavy rare earth elements (HREE) are more compatible than light rare earth elements (LREE). REE are incorporated into zircon by a coupled substitution with yttrium and

phosphorous, $(\mathrm{REE}+\mathrm{Y})^{+3}+\mathrm{P}^{+5}=\mathrm{Zr}^{+4}+\mathrm{Si}^{+4}$ (Belousova et al., 2002). The inclusion of certain REE, particularly Eu and Ce, into zircon is also affected by magmatic redox conditions (Trail et al., 2012). The melt source exerts initial control over REE abundances in a magma, with different source compositions producing characteristic REE patterns. Following partial melting, REE abundances can be altered by magmatic processes, often behaving predictively during melt evolution (Barth and Wooden, 2010).

\section{Zircon Saturation Thermometer}

The zircon saturation thermometer, initially described by Watson and Harrison (1983) and recently reevaluated by Boehnke et al. (2013), allows calculation of saturation temperature $\left(\mathrm{T}_{\mathrm{zrn}}\right)$ based on bulk rock peraluminosity and the partitioning of $\mathrm{Zr}$ between zircon and the melt. The peraluminosity parameter, $\mathrm{M}=(\mathrm{Na}+\mathrm{K}+2 \mathrm{Ca}) /(\mathrm{Al} \cdot \mathrm{Si})$, describes a ratio of network formers to network modifiers, and acts as a proxy for 
chemical processes that control zircon dissolution. The relationship is described by the following equation:

$$
\ln \left(\mathrm{D}_{\mathrm{Zr}}\right)=\frac{10108}{\mathrm{~T}(\mathrm{~K})}-1.16(\mathrm{M}-1)-1.48
$$

Where $\mathrm{D}_{\mathrm{Zr}}$ is the distribution coefficient of $\mathrm{Zr}$ between zircon and the melt, and $\mathrm{T}$ is temperature in Kelvin. Interpretation of $\mathrm{T}_{\mathrm{zrn}}$ is dependent upon zircon saturation conditions within the melt. In initially saturated melts, $\mathrm{T}_{\mathrm{zrn}}$ provides a maximum zircon crystallization temperature, which can be assumed equivalent to the initial magmatic temperature. In initially undersaturated melts, $T_{z r n}$ provides a minimum estimate of initial magmatic temperature, as it underestimates the actual zircon crystallization temperature due to the increase in $\mathrm{Zr}$ concentration from fractionation of modal minerals (Harrison et al., 2007).

\section{Ti in Zircon Thermometry}

Incorporation of Ti into zircon has been experimentally demonstrated to be directly related to crystallization temperature, making it a valuable thermometer for measuring magmatic temperatures (Watson and Harrison, 2005; Watson et al., 2006). Because Ti primarily substitutes for $\mathrm{Si}$ in the crystal lattice, the activities of both $\mathrm{SiO}_{2}$ and $\mathrm{TiO}_{2}$ in the melt affect this partitioning (Ferry and Watson, 2007). The following equation governs the relationship between Ti concentration in zircon, magma temperature, $\mathrm{a}_{\mathrm{SiO} 2}$, and $\mathrm{a}_{\mathrm{TiO} 2}$ :

$$
\log (\text { ppm Ti })=(5.711 \pm 0.072)-\frac{(4800 \pm 86)}{\mathrm{T}(\mathrm{K})-\log \left(\mathrm{a}_{\mathrm{SiO}_{2}}\right)+\log \left(\mathrm{a}_{\mathrm{TiO}_{2}}\right)}
$$


Estimating thermodynamic activities is complicated by the fact that many zircons did not grow in equilibrium with the final crystallized assemblage. Complex zonation in most crystals records changing magmatic conditions that likely included variations in the activities of both $\mathrm{SiO}_{2}$ and $\mathrm{TiO}_{2}$. Temperature calculations presented here use asio2=1 and $\mathrm{aTiO}_{2}=0.5$. Several studies have suggested a higher value for aTiO2 (Hayden and Watson, 2007; Claiborne et al., 2010). However, Mount Givens samples show a lack of MREE depletion in whole rock REE patterns and of MREE and HREE enrichment in zircon REE patterns. These trends suggest that titanite was a late crystallizing phase that was not concurrent with zircon crystallization. Calculating temperatures with an a $\mathrm{S}_{\mathrm{SiO} 2}=1$ is common due to the ubiquitous presence of quartz. If this is an overestimate, it will act to offset error incurred from an underestimate of aTiO2, as the activities have opposing effects on the calculated temperature.

The Ti in zircon thermometer has a slight pressure dependence, estimated at 5-10 ${ }^{\circ} \mathrm{C} / \mathrm{kbar}$ (Ferry and Watson, 2007; Ferriss et al., 2008). The thermometer is calibrated to a pressure of $10 \mathrm{kbar}$, approximately $6.6 \mathrm{kbar}$ higher than the crystallization pressure of the Mount Givens granodiorite as calculated by Al-in-hornblende thermobarometry. This difference may result in an overestimation of magmatic temperature by approximately $30-60{ }^{\circ} \mathrm{C}$. However, this error has no effect on relative temperature differences within the zircon population, and calculations using this thermometer produce reasonable magmatic temperatures (Claiborne et al., 2010). 


\section{METHODS}

\section{Zircon Separation and Imaging}

In total, thirty-five samples were collected for petrographic, geochemical, and isotopic analysis (See Appendix A for comprehensive list of locations and descriptions). Fourteen samples were prepared for zircon in-situ analysis (Fig. 5). Zircons were separated at San José State University using standard separation techniques. Samples were first crushed in a jaw crusher, and then pulverized in a steel disk mill to reduce grain size to less than $1 \mathrm{~mm}$. Zircons were separated from other minerals using a Wilfley table, magnetic separation, and two heavy liquid separations (Bromoform and Methylidodide). Finally, zircons were hand-picked and mounted and polished in 1" epoxy rounds at Stanford University. Mounts were imaged with cathodoluminescence (CL) on the scanning electron microscope at Stanford University in order to image zonation and internal structure to pick spots for analysis targets (see Appendices B and C for zircon CL images). Mounts were also imaged in transmitted light to identify inclusions that might affect analysis. 


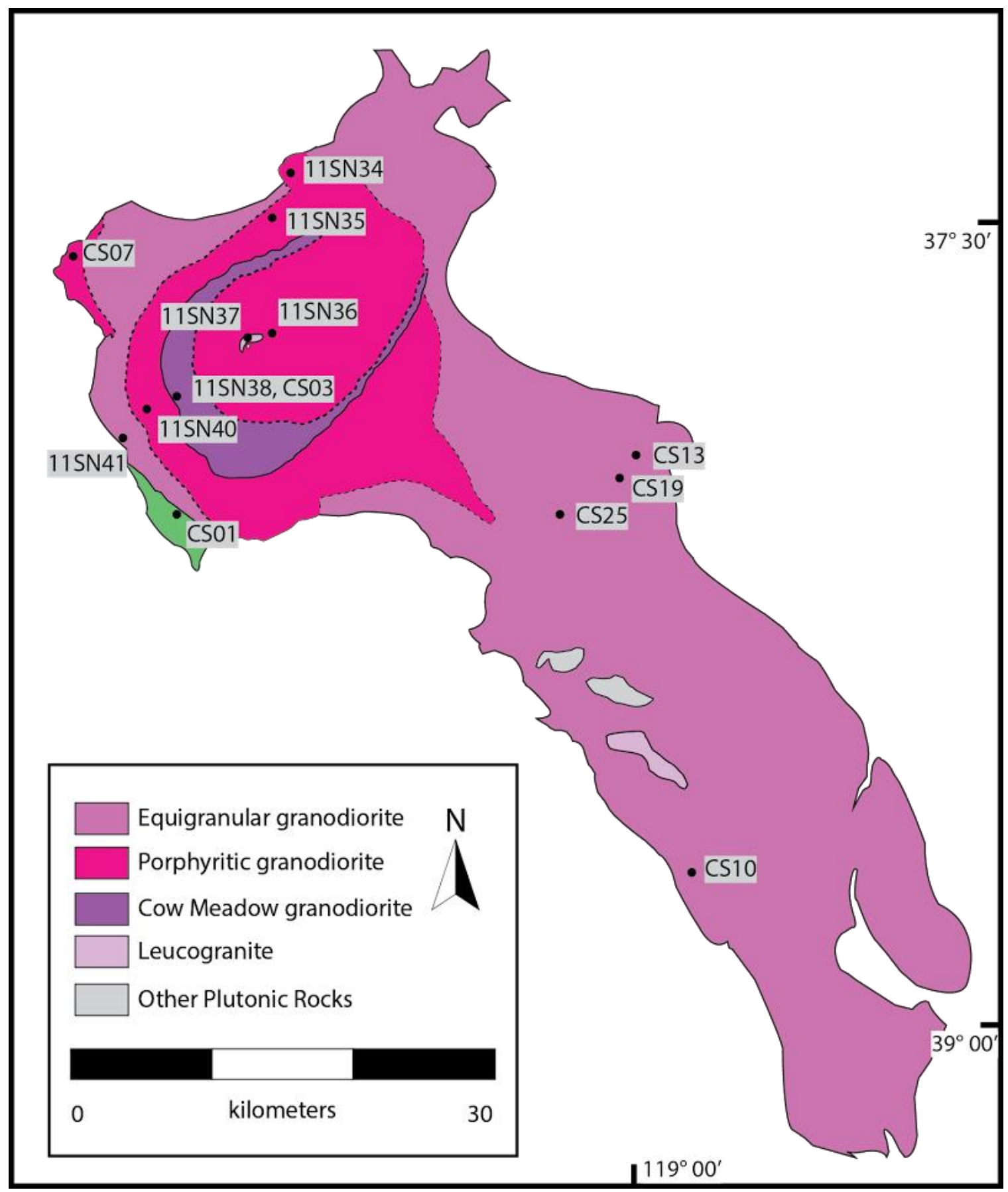

Figure 5. Zircon sample location map. See Appendix A for full list of sample locations and descriptions. 


\section{Whole Rock Geochemistry}

Whole rock analysis of major and trace elements was completed at the Washington State University (WSU) GeoAnayltical Lab and the Pomona College XRF Lab. Fractions of coarsely crushed rock were separated prior to pulverization, and weathered chips were removed prior to sample preparation for XRF and ICP-MS. Samples with a "CS" prefix were sent as coarsely crushed rock to WSU for both XRF and ICP-MS characterization. Samples with an "11SN" prefix were first analyzed at the XRF Lab at Pomona College, and then powders were sent to WSU for complementary ICP-MS data. Sample preparation at Pomona College followed an identical procedure to the one used at WSU. Powders were prepared in a shatter box with a tungsten-carbide head, and then diluted with Li-Tetraborate in a 2:1 ratio. Double fusion in graphite crucibles was used to make glass beads. Analytical procedures for both labs follow similar protocols (see Lackey et al., 2012).

\section{Trace Elements in Zircon}

In situ trace element data in zircon was obtained using the Sensitive HighResolution Ion Microprobe-Reverse Geometry (SHRIMP-RG) at the joint StanfordUSGS facility. Analytical procedures are analogous to those described in Claiborne et al. (2010) and Barth and Wooden (2010). The secondary beam was produced using a 1.5$2.5 \mathrm{nA} \mathrm{O}^{2-}$ primary beam. The beam produced a spot size of approximately $20 \mu \mathrm{m}$. Mass resolution on this machine is approximately 11000 at $10 \%$ peak height. Each analysis began with a 30 second raster period, followed by sequential analysis of the elements of interest (30 in total). Concentrations were calculated relative to the MADDER standard 
(Barth and Wooden, 2010), and corrected for during offline data reduction performed using the SQUID 2 software package (Ludwig, 2009). Counts from each element were ratioed to ${ }^{30} \mathrm{Si}^{+}$counts to account for variation in beam intensity. Measurements were screened for inclusions (usually evident by high Fe or Al concentrations), which were removed from the overall dataset.

\section{SIMS Analysis of $\delta^{18} \mathrm{O}$ of Zircon}

Values for $\delta^{18} \mathrm{O}$ of zircon was measured at University of Wisconsin-Madison using the CAMECA IMS 1280 with Faraday collection cups. Mounts were polished to remove trace element spots and implanted O from the SHRIMP analyses, then gold coated to mitigate charging. Analyses were located in the same zones as trace element spots to provide correlation between the two data sets. Analyses followed the routine described in Kita et al. (2009). A $\sim 15 \mathrm{~nm}$ spot size was achieved with a $\mathrm{Ce}^{+}$beam of $\sim 2$ nA. Secondary ions were accelerated across a $10 \mathrm{keV}$ charge differential, and passed through a $40 \mathrm{eV}$ energy slit to enter the mass spectrometer. Mass resolution of the instrument is approximately 2200. Total analysis time is approximately 3.5 minutes, including 10 seconds of presputtering and 120 seconds of automated secondary ion

centering. Integrated measurements of $\mathrm{O}$ isotopes occurs in 20 cycles. ${ }^{16} \mathrm{OH} /{ }^{16} \mathrm{O}$ was monitored to ensure no targets were hydrated, which would cause erroneous isotopic composition.

The standard 91500, with an accepted value of 10.07\%o (Valley, 2003), was used to monitor instrumental mass bias and consistency. External precision for the entire run 
had a two standard deviation (2SD) value of $0.4 \%$ (Fig. 6). All O data, including standard measurements, are reported in Appendix D.

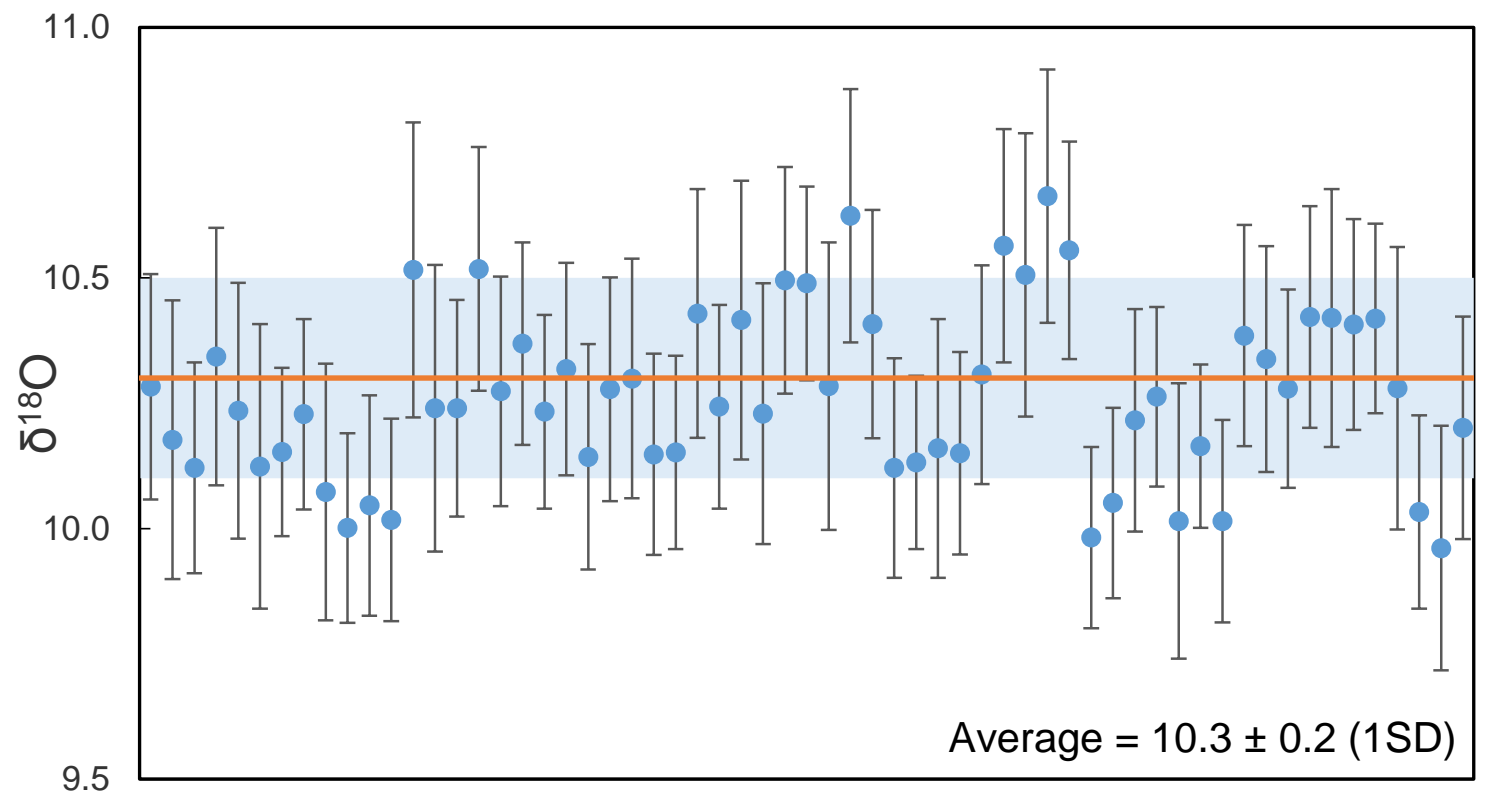

Figure 6. External error plot for 91500 zircon standard. Individual analysis errors are two standard error (2SE). The orange line and blue shading indicate the average $\delta^{18} \mathrm{O}$ and 1SD for all 91500 analyses. Accepted value for 91500 is $10.07 \%$ (Valley, 2003).

\section{Hf Isotopes in Zircon}

Following trace element and $\mathrm{O}$ isotopic analysis, grains were analyzed for $\mathrm{Hf}$ isotopic composition on the Thermo-Finnigan Neptune multi-collector, inductively coupled, plasma mass-spectrometer at the Vrije Universiteit, Amsterdam. Measurements for this study were made on the first two days of a five day analytical session. Material was ionized using a $193 \mathrm{~nm}$ Lambda Physik excimer laser ablation system. The laser was operated at an energy of $7 \mathrm{~J} / \mathrm{cm}^{2}$ with a pulse frequency of $7 \mathrm{~Hz}$ to produce a spot size of $49 \mu \mathrm{m}$. The laser operated in a He atmosphere, and a mixed He and Ar carrier gas 
transported ablated material to the plasma source. Ablation runs lasted between 30 and 90 1-second cycles depending on grain depth, which was monitored by the ${ }^{180} \mathrm{Hf}$ signal. The average ${ }^{176} \mathrm{Hf}$ signal intensity for typical runs was between 250 and $300 \mathrm{mV}$. Sixty second blank corrections preceded each analysis.

Because laser ablation is an in-situ technique, isobaric interferences on ${ }^{176} \mathrm{Hf}$ by ${ }^{176} \mathrm{Yb}$ and ${ }^{176} \mathrm{Lu}$ must be corrected by monitoring interference-free isotopes of the same elements. Both ${ }^{171} \mathrm{Yb}$ and ${ }^{173} \mathrm{Yb}$ were measured to correct the ${ }^{176} \mathrm{Yb}$ interference. The measured ${ }^{171} \mathrm{Yb} /{ }^{173} \mathrm{Yb}$ was compared to the accepted value of 0.882858 (Chu et al., 2002) and used to calculate the $\mathrm{Yb}$ mass fractionation factor. This fractionation factor was applied to the interference correction, which utilized the accepted value of ${ }^{176} \mathrm{Yb} /{ }^{173} \mathrm{Yb}=$ 0.796328 (Chu et al., 2002) to correct for ${ }^{176} \mathrm{Yb}$ interference on ${ }^{176} \mathrm{Hf}$.

The interference of ${ }^{176} \mathrm{Lu}$ is smaller than that of ${ }^{176} \mathrm{Yb}$; however the correction is carried out in a similar fashion. Mass fractionation effects are accounted for by a Hf mass fractionation factor based on the accepted value ${ }^{179} \mathrm{Hf} /{ }^{177} \mathrm{Hf}=0.7325$ (Vervoort et al., 2004). The interference correction is then made using the accepted ${ }^{176} \mathrm{Lu} /{ }^{175} \mathrm{Lu}$ value of 0.02655 (Vervoort et al., 2004).

All corrections were performed offline on a macro-enabled Excel spreadsheet. Measurements of ${ }^{176} \mathrm{Hf} /{ }^{177} \mathrm{Hf},{ }^{176} \mathrm{Lu} /{ }^{177} \mathrm{Hf}$, and ${ }^{176} \mathrm{Hf} \mathrm{mV}$ for all cycles were manually evaluated for each run to screen for isotopic zonation and data quality. Between 25 and 90 cycles, depending on grain size and data scatter, were selected for inclusion into final isotopic calculations for each spot. All unknown ratios were age corrected based on a representative age of $95 \mathrm{Ma}$. Changing this age by $5 \mathrm{Ma}$ in either direction, which would 
encompass the entire age range of the pluton, changes the $\varepsilon H f$ by only $0.2 \varepsilon$ units, well below the typical internal precision of measurements.

Experimental bias throughout the run was checked with the JG-1 standard, with an accepted ${ }^{176} \mathrm{Hf} /{ }^{177} \mathrm{Hf}$ of $0.282000 \pm 0.000005$ (Morel et al., 2008). A total of $88 \mathrm{GJ}-1$ spots were analyzed over the two days of unknown measurements. The first day of measurements had an average of $0.282008 \pm 0.00005$, and the second day average was $0.282018 \pm 0.00005$. The combined two day average was $0.282014 \pm 0.00005$ (Fig. 7)

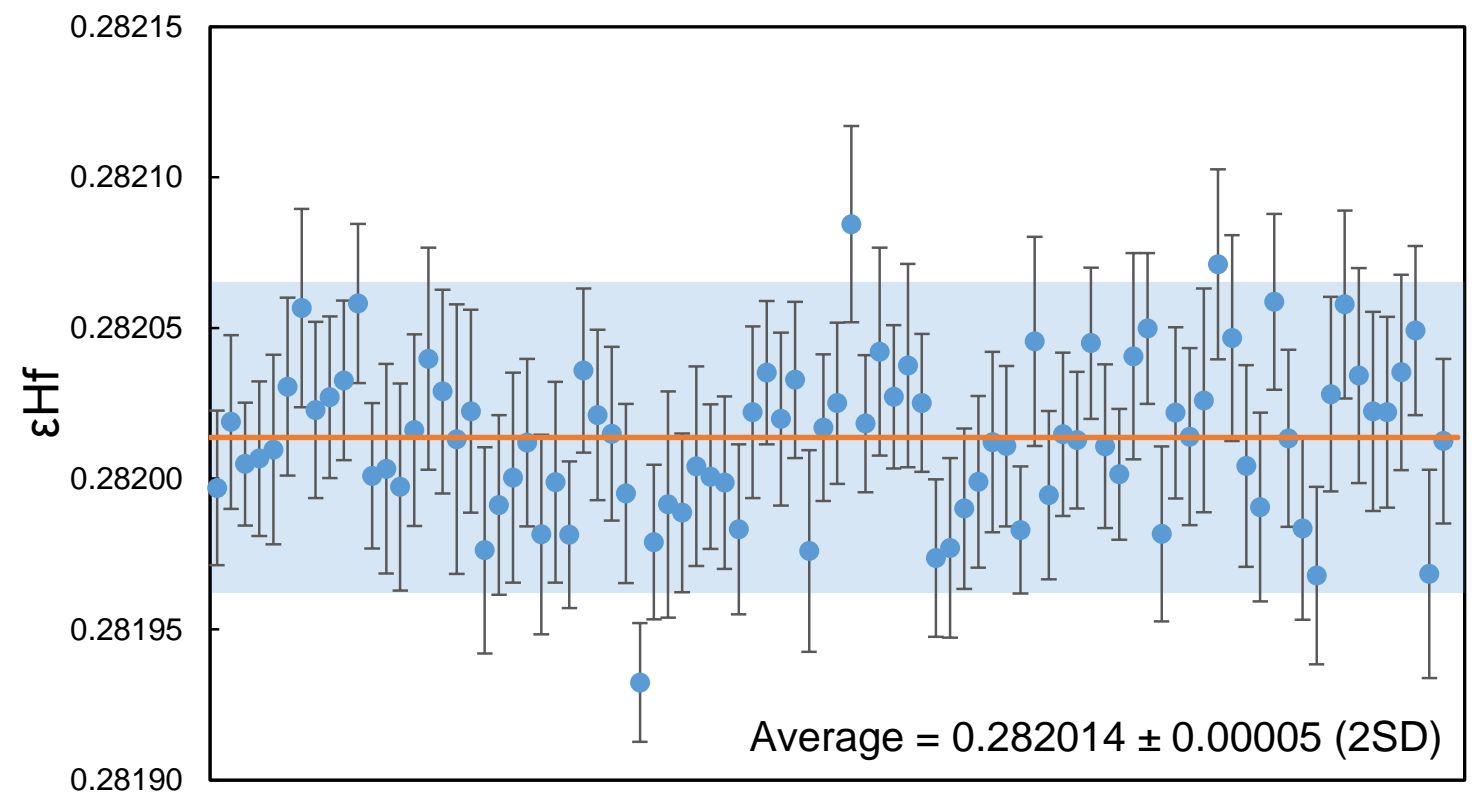

Figure 7. External error plot for JG1 zircon standard. Individual analysis errors are 2SE. Orange line and blue shading indicate the average and 2SD of all analyses. The accepted value for the JG1 standard is $0.282000 \pm 0.000005$ (Morel et al., 2008).

The standard R33 was also monitored, although less frequently, throughout the session. This standard is useful in assessing the isobaric interference corrections, as it has significantly higher concentrations of ${ }^{176} \mathrm{Lu}$ and ${ }^{176} \mathrm{Yb}$ (by up to a factor of 10). The 
accepted ${ }^{176} \mathrm{Hf} /{ }^{177} \mathrm{Hf}$ value for R33 is $0.282764 \pm 0.000014$ (Fisher et al., 2014). Averages and standard deviations for the two days were variable, with the first day $(\mathrm{n}=19)$ producing $0.28276 \pm 0.00007$, and the second day $(\mathrm{n}=7)$ producing $0.28288 \pm 0.00016$. The two day average was $0.28279 \pm 0.00015$ (Fig. 8). The seven R33 spots run on the second day are more variable and above both the accepted value and the average from the previous day.

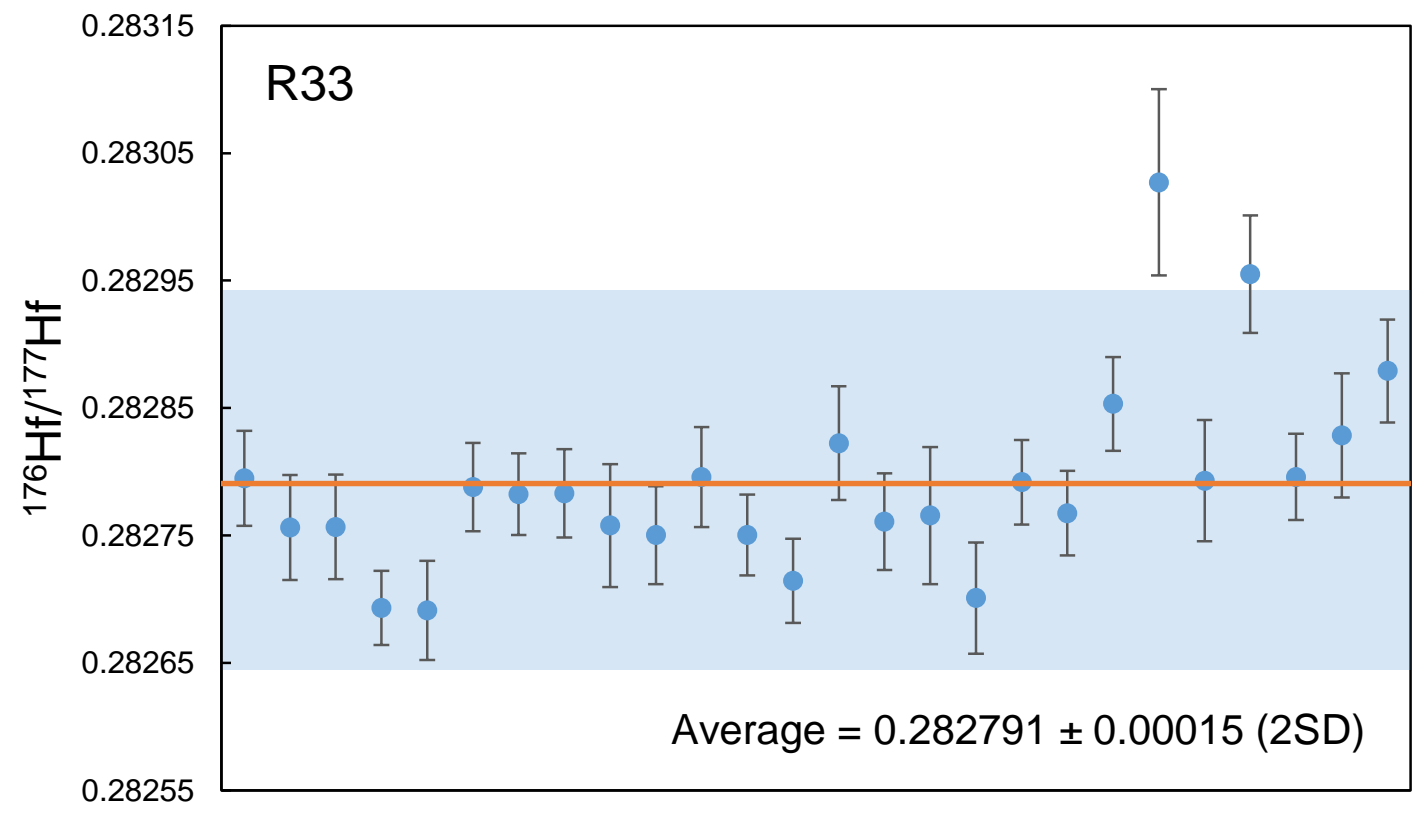

Figure 8. External error plot for R33 zircon standard. Individual analysis errors are 2SE. Orange line and blue shading indicate the average and 2SD of all analyses. The accepted value for the R33 standard is $0.282764 \pm 0.000014$ (Fisher et al., 2014).

Data from the R33 analyses show a correlation between ${ }^{176} \mathrm{Yb} /{ }^{177} \mathrm{Hf}$ and ${ }^{176} \mathrm{Hf} /{ }^{177} \mathrm{Hf}$ for ${ }^{176} \mathrm{Yb} /{ }^{177} \mathrm{Hf}$ greater than 0.1 (Fig. 9). The high ${ }^{176} \mathrm{Hf} /{ }^{177} \mathrm{Hf}$ analyses from day two all have high ${ }^{176} \mathrm{Yb} /{ }^{177} \mathrm{Hf}$ values. This suggests that either the R33 in the mount run on the second day had unusually high concentrations of ${ }^{176} \mathrm{Yb}$, or that an analytical 
issue arose which affected isotopic measurements. As the pattern of sporadic R33 results continued during day three and four of the analytical session (Fig. 10), it is believed there may have been a mechanical problem. However, R33 analyses largely returned to within error of the reported average during the final day of the analytical session, and in a subsequent session of R33 measurements. Evaluation of the R33 standard is ongoing, and further testing may show evidence of isotopic heterogeneity.

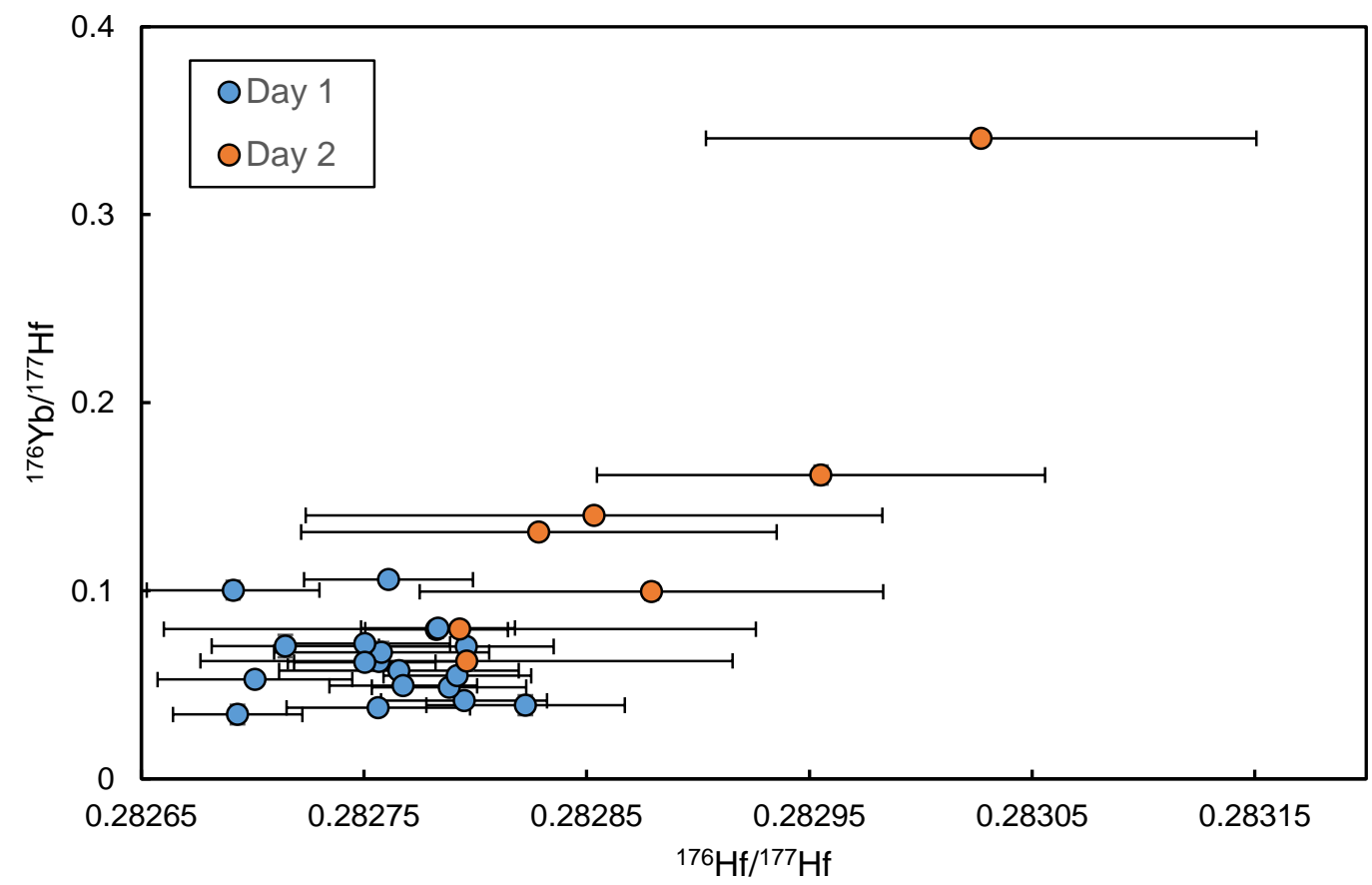

Figure 9. ${ }^{176} \mathrm{Hf} /{ }^{177} \mathrm{Hf}$ vs ${ }^{176} \mathrm{Yb} /{ }^{177} \mathrm{Hf}$ for all R33 analyses. Analyses are colored based on the day the measurement was performed. Error bars are 2SE. The errors in ${ }^{176} \mathrm{Yb} /{ }^{177} \mathrm{Hf}$ measurements are approximately the same size as measurement symbols. 


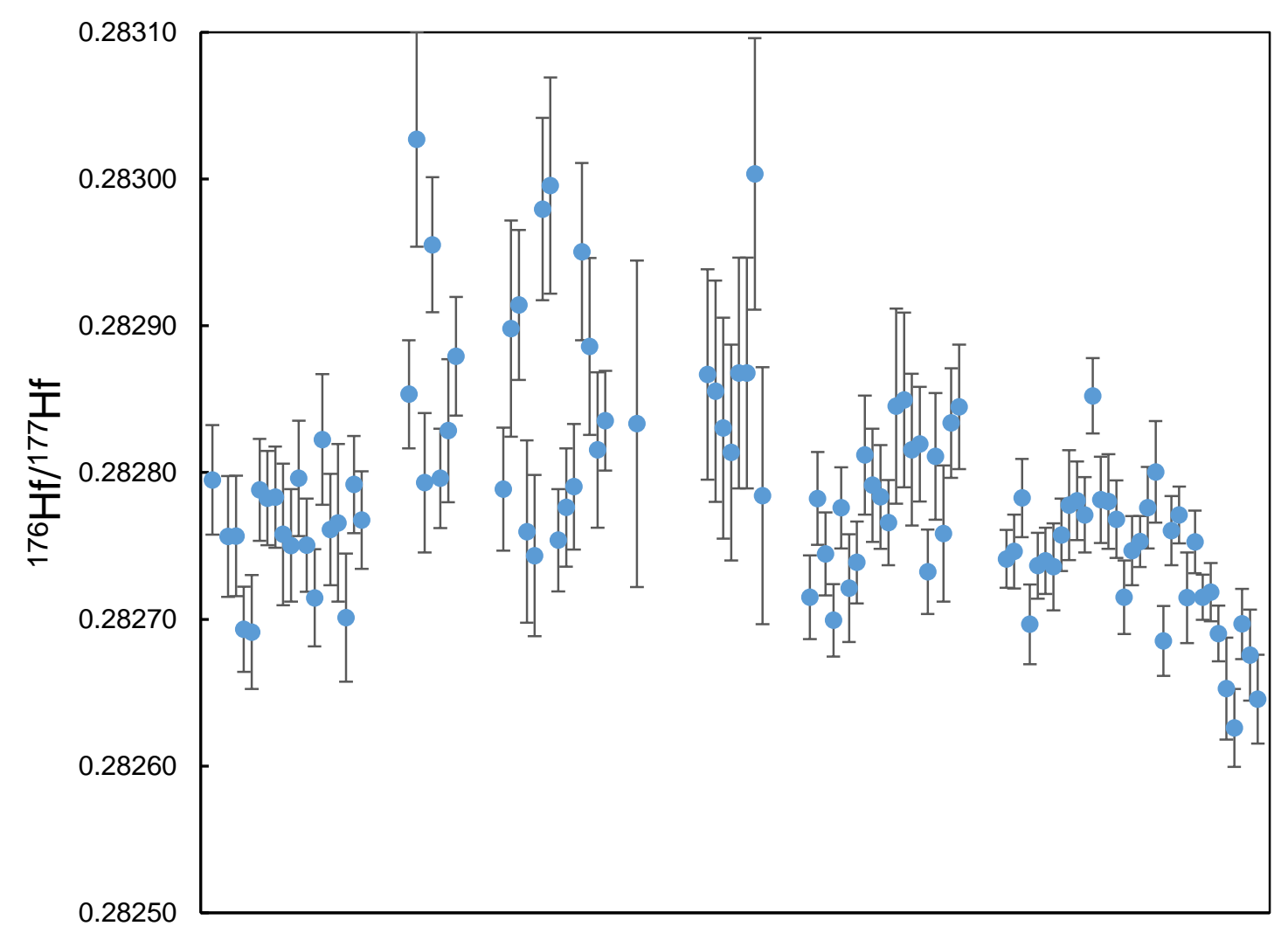

Figure 10. R33 Standard measurements for entire Hf analytical session. Data are grouped into individual days of analysis. Error bars are 2 SE.

The Plešovice standard, with an accepted ${ }^{176} \mathrm{Hf} /{ }^{177} \mathrm{Hf}$ value of $0.282482 \pm$ 0.000013 (Sláma et al., 2008), was run only on the second day and provided an excellent absolute value and standard deviation (Fig. 11). The consistency of both JG-1 and Plešovice indicates that the issue encountered with R33 during the second day did not affect standards with low interference corrections. Because of possible issues with measurement and correction of high interference measurements, all unknown analyses with ${ }^{176} \mathrm{Yb} /{ }^{177} \mathrm{Hf} \geq 0.1$ have been discarded. External error for all analyses is reported as $2 \varepsilon \mathrm{Hf}$, which is conservative. All Hf data are reported in Appendix E. 


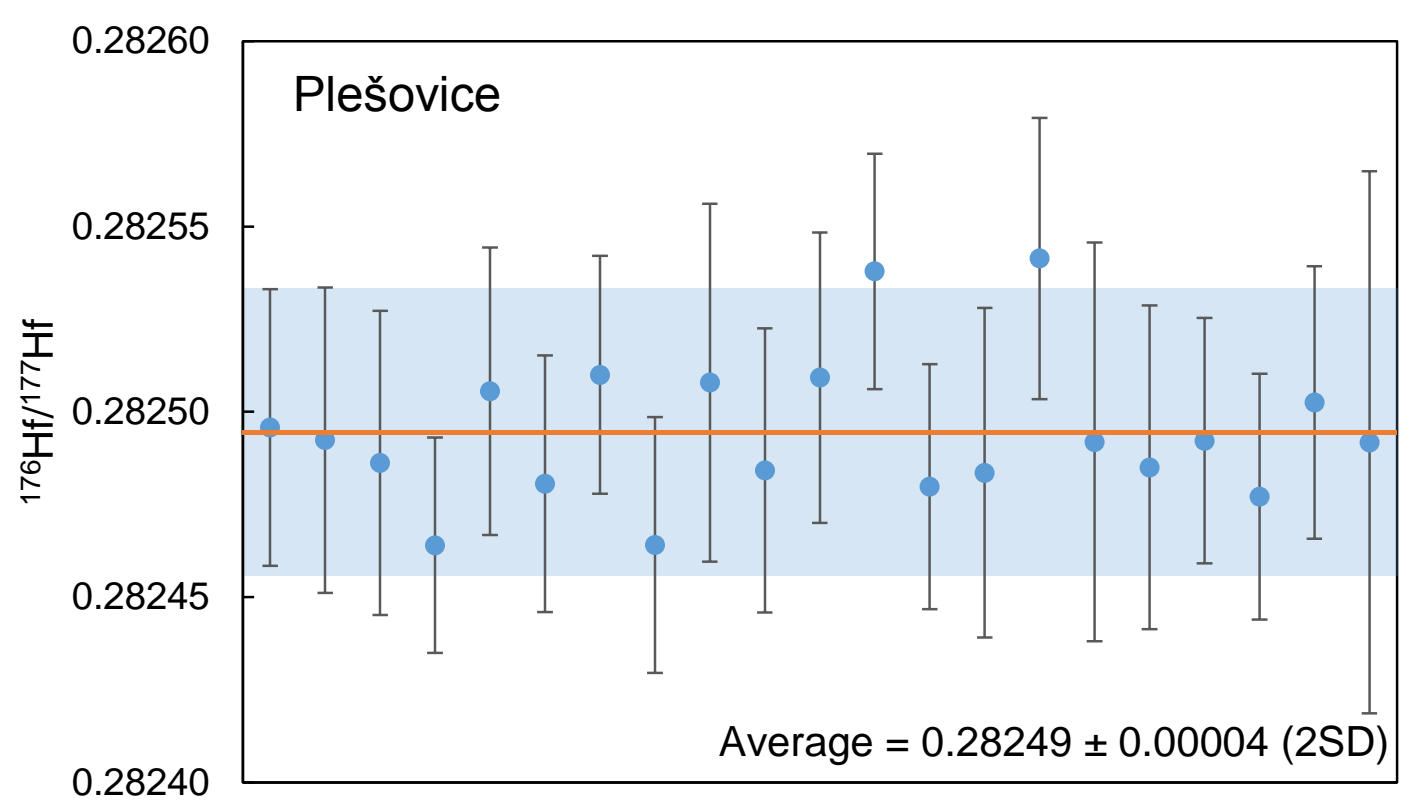

Figure 11. External error plot for Plešovice zircon standard. Individual analysis errors are 2SE. Orange line and blue shading indicate the average and 2SD of all analyses. The accepted value for the Plešovice standard is $0.282482 \pm 0.000013$ (Sláma et al., 2008).

\section{FIELD OBSERVATIONS}

\section{Northern Lobe}

The northern lobe of the Mt. Givens pluton is petrologically and texturally diverse, containing both the equigranular and porphyritic phases of the Mount Givens granodiorite, as well as the granodiorite of Cow Meadow, and the aplite of Jackass Rock (Fig. 12). Due to cover, the contacts between these units are generally inferred. The exterior contact of the granodiorite of Cow Meadow was not observed, but has been mapped as sharp and intrusive by several previous studies (Bateman and Nokleberg, 1978; McNulty et al., 2000). 


\section{Equigranular Granodiorite}

Equigranular granodiorite composes the majority of the outer "shell" of the northern lobe (Fig. 2). It has an average color index of 10-15, becoming more felsic inwards. The most mafic area observed was in the northern margin, where color index reached 20. The equigranular phase is medium grained, with felsic minerals averaging $2.5 \mathrm{~mm}$. Hornblendes are euhedral in the margins and reach up to $2 \mathrm{~cm}$ in length (throughout this section, reported mineral size refers to length). They become smaller and more subhedral moving inwards as biotite becomes the predominant mafic mineral. Mafic minerals define a strong, steeply dipping magmatic foliation that is roughly parallel to concentric unit contacts (McNulty et al., 2000). Titanite, up to $3 \mathrm{~mm}$, is the most common accessory mineral, making up as much as $1 \%$ of the rock in places.

\section{Porphyritic Granodiorite}

The porphyritic phase makes up the majority of the northern lobe, existing largely in the core, but also along the northwest margin (Fig. 2). The porphyritic phase is less mafic than the equigranular phases, with an average color index of 5-10. Like the equigranular phase, the porphyritic phase is most mafic where it appears on the margins, reaching a color index of up to 15 . Grain size is overall coarser in this phase, with felsic minerals commonly reaching $5 \mathrm{~mm}$. Hornblendes are more common in marginal areas, reaching up to $1 \mathrm{~cm}$. Potassium feldspar phenocrysts are an average of $2-3 \mathrm{~cm}$, but reach up to $4 \mathrm{~cm}$, and exhibit zonation defined by mafic minerals. Fabrics in the porphyritic phase are poorly developed. 

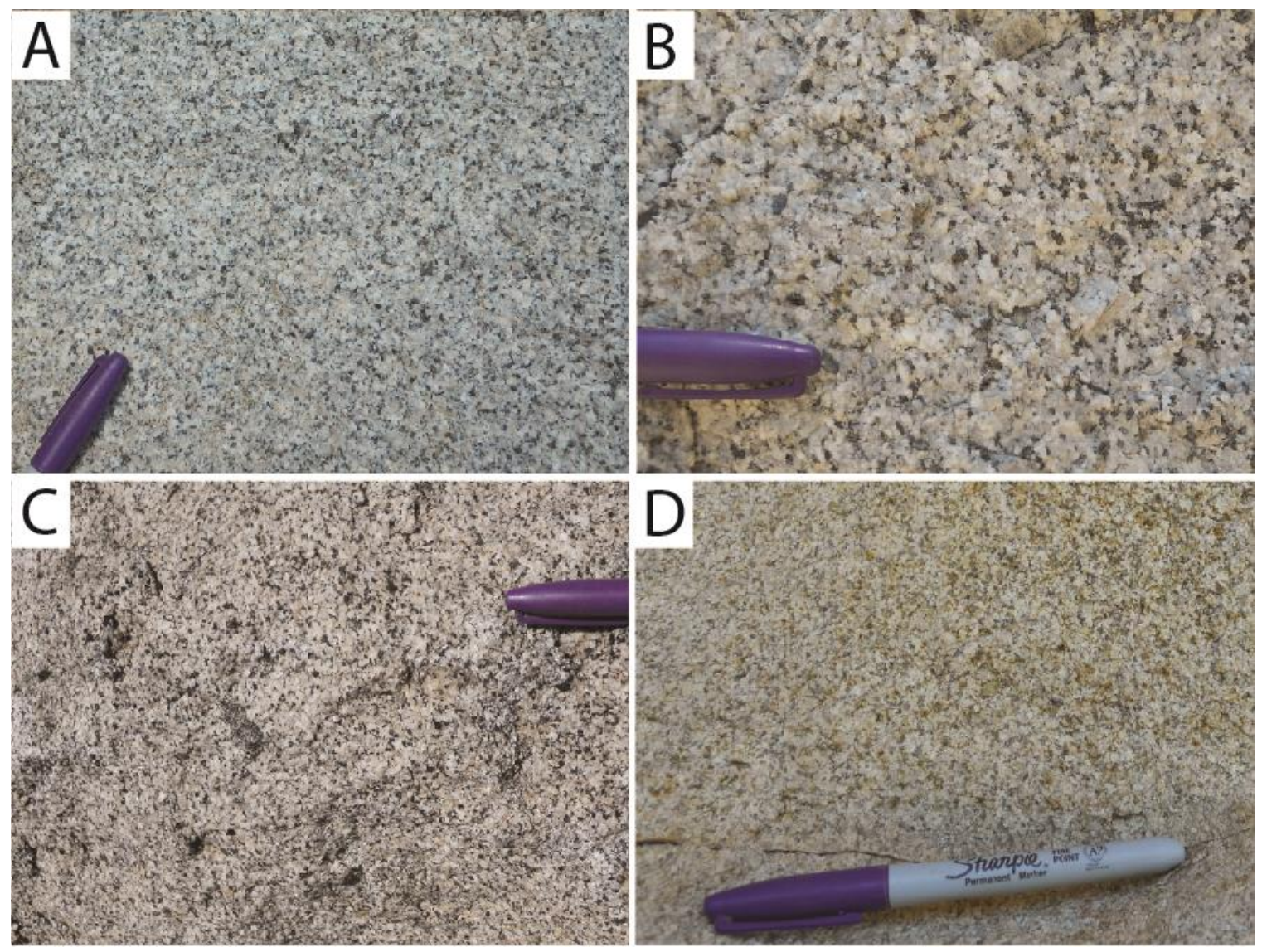

Figure 12. Representative rock textures in the northern lobe. (a) Equigranular granodiorite. (b) Porphyritic granodiorite. (c) Granodiorite of Cow Meadow. (d) Aplite of Jackass Rock.

\section{Granodiorite of Cow Meadow}

The granodiorite of Cow Meadow is horseshoe-shaped in map view, and lies completely within the porphyritic phase (Fig. 2). It is a medium grained, equigranular granodiorite. It is more mafic than the porphyritic material on either side, with average color index of approximately 15. As in other units, hornblende is the dominant mafic mineral; crystals are euhedral and reach $1 \mathrm{~cm}$. Titanite composes 1-2\% of the rock. Magmatic foliation defined by mafic minerals is moderately well developed, steeply dipping, and oriented roughly parallel to unit contacts. 


\section{Aplite of Jackass Rock}

The aplite of Jackass Rock is better described as a homogeneous, fine-grained leucogranite. For consistency with the literature, the term "aplite of Jackass Rock" is used throughout this discussion; however, the sample will be pictured as a leucogranite in compositional diagrams. Felsic minerals are 1-2 $\mathrm{mm}$ in size. Occasional potassium feldspar phenocrysts reach up to $5 \mathrm{~mm}$. The color index of the rock is approximately 2 , and the primary mafic component is anhedral biotite of approximately $1 \mathrm{~mm}$.

\section{Enclaves of the Northern Lobe}

Enclaves are common in the Northern lobe, particularly in the more mafic marginal areas and the granodiorite of Cow Meadow. Enclaves typically have a finegrained matrix of biotite, hornblende, and plagioclase. Many also contain varying proportions of phenocrysts of these three minerals. The shapes of enclaves range from very elongate (aspect ratios $\geq 10: 1$ ) to spherical, with lens shapes usually elongated in the directions of magmatic foliation. Some enclaves maintain discrete boundaries, while others appear to be in varying stages of disintegration with jagged edges and embayed crystals that are likely incorporated from the host. Enclaves in the porphyritic phase are $\leq 10 \mathrm{~cm}$. Whereas enclaves in the two equigranular phases are up to $60 \mathrm{~cm}$ in length, and recorded by other researchers to be up to $1 \mathrm{~m}$. Five enclave swarms have been mapped in the Northern lobe (Tobisch et al., 1997), but were not observed in this study. 


\section{Mixing Zone}

On the eastern side of the central portion of the pluton, Bateman et al. (1971) mapped an area of equigranular granodiorite with an extraordinary abundance of subangular mafic inclusions. Field observations indicate that this area may be more adequately interpreted as a mixing or hybridization zone. At least four generations of magma were observed: equigranular Mount Givens granodiorite; a felsic endmember; a mafic endmember; and an intermediate hybrid (Fig. 13).

The Mount Givens granodiorite in this zone largely acted as the host rock for later magma injections. Xenoliths of equigranular Mount Givens granodiorite (10s of $\mathrm{cm}$ in length) within the intermediate magma showed varying degrees of disaggregation. In places, dikes of the hybrid magma intruded equigranular granodiorite, showing sharp boundaries. In other places, the boundary between the equigranular granodiorite and the hybrid was more wispy and elongated pieces of equigranular granodiorite were entrained within the hybrid. Large hornblendes within the hybrid may have been xenocrysts incorporated from disaggregation of the Mount Givens granodiorite as has been suggested for other locations in the Sierra Nevada batholith (Reid and Hamilton, 1987). Boundaries of large angular blocks of mafic material within the Mount Givens varied between sharp and crenulated, indicating some melting of the Mount Givens granodiorite. The highest degree of remobilization was observed near large mafic bodies in the central region, which were often surrounded by hybrid magmas with hornblendes and crenulated margins. Crenulated margins between mafic and hybrid magmas suggest that they were 
largely coeval. However, chilled margins on some mafic enclaves within the hybrid suggest multiple episodes of mafic magma injection.
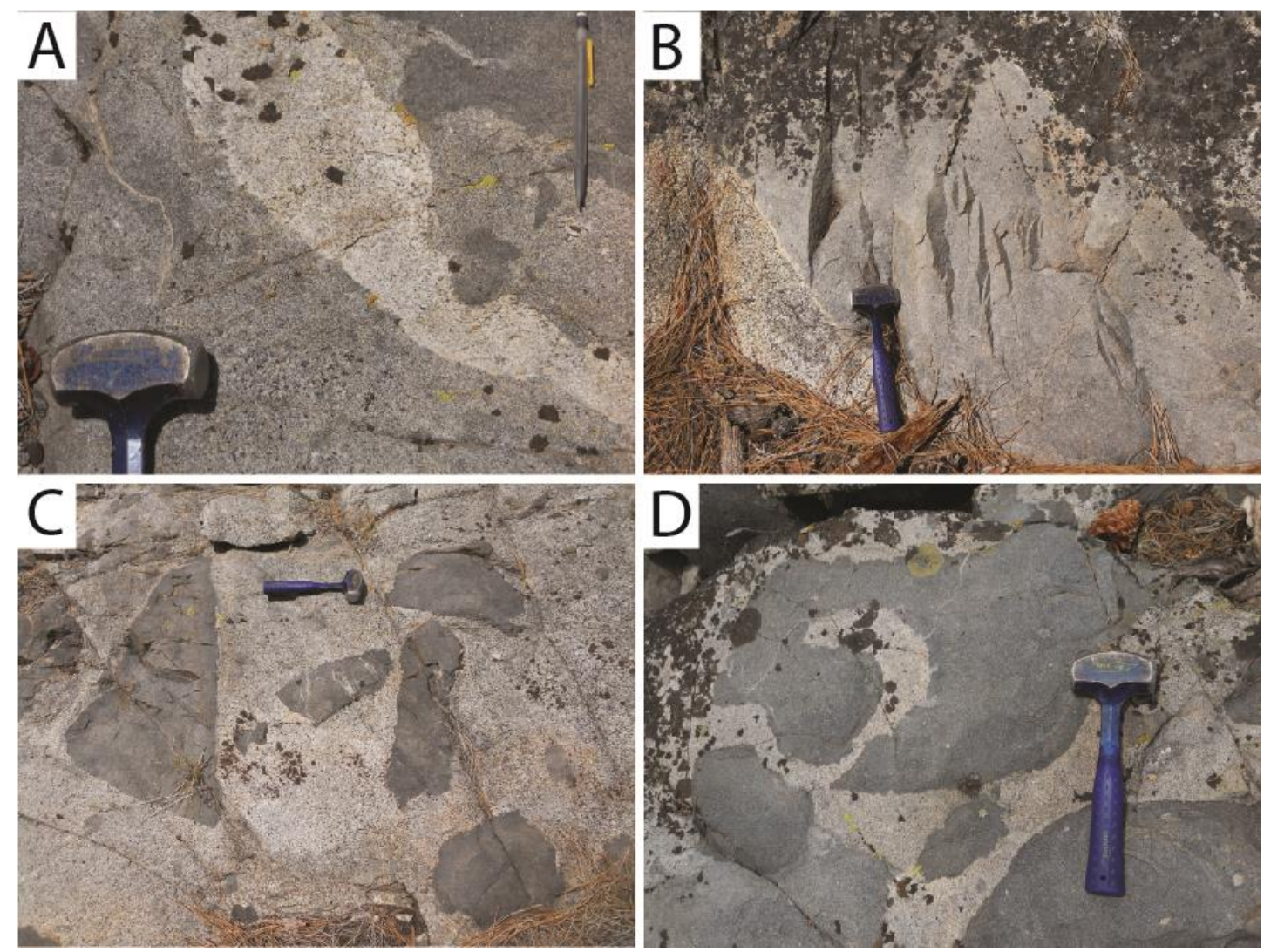

Figure 13. Magmatic interactions in central mixing zone. Hammer is $28 \mathrm{~cm}$ long. (a) Cross-cutting relationships between four generations of magma. Disaggregating xenoliths of equigranular granodiorite within hybrid magma, interactions between hybrid and mafic magmas, cross-cutting felsic dike. (b) Dike of intermediate magma intruding equigranular granodiorite. (c) Angular fragments of mafic material in equigranular granodiorite; some margins are sharp, while others show evidence for magmatic interaction. (d) Large mafic enclaves with crenulated margins and veins of hybrid magma.

A large ( $\sim 50 \mathrm{~m})$ enclave swarm was observed in the central portion of the Mount Givens pluton. Enclaves vary in size up to $50 \mathrm{~cm}$ in length. Several enclaves were composed of the hybrid magma, while some were of a more mafic composition. 


\section{Courtright Reservoir}

Mount Givens granodiorite in the southern portion of the pluton was observed around Courtright Reservoir (Fig. 2). The granodiorite is largely coarse grained, with an average grain size of 2-4 mm. Color index is fairly consistent, and is $\sim 10$. Mafic minerals are generally subhedral, with biotite in greater abundance than hornblende. The size of mafic minerals varies, with hornblendes reaching $8 \mathrm{~mm}$ in places, and biotites as large as $4 \mathrm{~mm}$. Titanite is common, euhedral, and up to $3 \mathrm{~mm}$ in size. Sparse potassium feldspar phenocrysts are present in most locations, commonly $1-2 \mathrm{~cm}$, but reaching up to $4 \mathrm{~cm}$. Enclaves are common in the southern region, and vary in modes and texture. Several types of enclaves were identified: (1) fine-grained, felsic enclaves with large, subhedral hornblende phenocrysts; (2) fine-grained mafic enclaves with plagioclase phenocrysts, occasionally cored by titanite; and (3) coarser-grained felsic enclaves with plagioclase, hornblende, and biotite phenocrysts (Fig. 13). All three types were observed in an enclave swarm approximately $1.5 \mathrm{~m}$ wide and $10 \mathrm{~m}$ long. Enclaves in this swarm are tightly packed with high concentrations of mafic mineral aggregates surrounding them. Schlieren range from approximately 5 to $30 \mathrm{~m}$ long and are up to $1 \mathrm{~m}$ wide.

Bodies mapped as aplite in the southern portion of the pluton can be better described as fine-grained leucogranites, and will be referred to as such in the following discussion. The average grain size is approximately $1 \mathrm{~mm}$, with occasional subhedral quartz up to $0.5 \mathrm{~cm}$ and euhedral plagioclase phenocrysts of $1-2 \mathrm{~cm}$. The rock has a color index of approximately $3-5$, with biotite making up nearly all of the mafic component. 

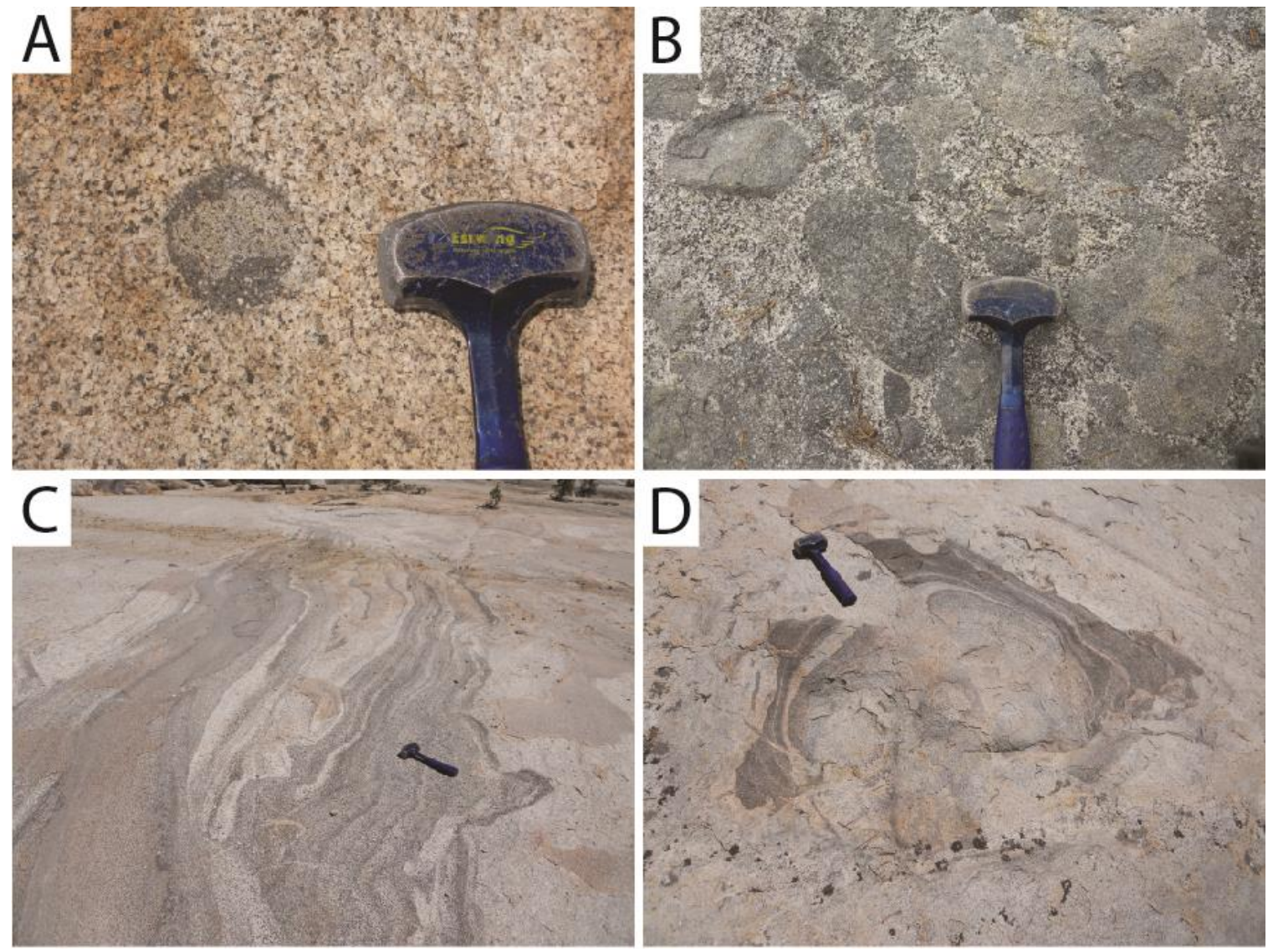

Figure 14. Mafic enclaves and schlieren near Courtright Reservoir. Hammer is $28 \mathrm{~cm}$ long. (a) Rounded enclave containing both mafic and felsic phases. (b) Enclave swarm showing at least three petrologically different mafic magmas. (c) Elongate schlieren approximately $30 \mathrm{~m}$ long. (d) Circular schlieren in equigranular Mount Givens.

\section{RESULTS}

\section{Point Counts}

Point counts were performed on 21 samples, including 11 from the northern lobe, 7 from a central transect, and 3 from the southern portion of the pluton. Results are presented in Table 1. Equigranular granodiorite, porphyritic granodiorite, and the granodiorite of Cow Meadow (abbreviated as eKmg, pKmg, and CM in Table 1) of the northern lobe display variations in modal mineralogy. Samples CS06 and CS05 are on 
the margin of the northern contact with host rock, and are largely inconsistent with trends seen in the other samples, and are thus discussed separately.

The overall low percentage of mafic minerals in the porphyritic granodiorite (2$10 \%)$ is dominated by biotite (80-100\%). This unit also contains samples with the highest proportions of potassium feldspar (up to $35 \%$ in the northwest corner), with significant variation in relative proportions of microcline and orthoclase. There are no clear patterns moving inwards in the pluton, but the innermost porphyritic sample (11SN36) has a very low proportion of mafic minerals, all of which are biotite.

The granodiorite of Cow Meadow is slightly more mafic than the porphyritic granodiorite (10-12\%), with higher percentages of hornblende (20-23\% of mafic minerals). Both samples of the granodiorite of Cow Meadow are located relatively close together in the unit, and thus more variation may be present. This unit has a more plagioclase than porphyritic samples, but less than equigranular ones.

The single equigranular sample is the most mafic (17\%) in the northern lobe, and has a significantly higher proportion of hornblende (27.1\%). Proportions of normalized plagioclase are higher than elsewhere in the northern lobe. CS05, the marginal equigranular sample, follows similar trends with the felsic minerals, but is significantly more mafic (19\%), with very high percentages of hornblende (42\%). Both samples lack microline, with all potassium felsdpar existing as orthoclase.

The aplite of Jackass Rock has only very small proportions of biotite (color index =2). Proportions of modal felsic minerals are approximately equivalent. 
Table 1: Point Count Data

\begin{tabular}{|c|c|c|c|c|c|c|c|c|c|c|c|c|}
\hline \multicolumn{2}{|l|}{ Sample } & Quartz & Plagioclase & Microcline & Orthoclase & Biotite & Hornblende & Titanite & Opaques & $\mathbf{Q}$ & $\mathbf{A}$ & $\mathbf{P}$ \\
\hline \multicolumn{13}{|c|}{ Northern Lobe } \\
\hline $11 \mathrm{SN} 34$ & $\mathrm{pKmg}$ & 187 & 200 & 65 & 3 & 35 & 4 & 4 & 2 & 41.1 & 14.9 & 44.0 \\
\hline $11 \mathrm{SN} 35$ & pKmg & 156 & 209 & 57 & 30 & 37 & 9 & 2 & 0 & 34.5 & 19.2 & 46.2 \\
\hline 11SN36 & pKmg & 169 & 207 & 80 & 31 & 10 & 0 & 1 & 2 & 34.7 & 22.8 & 42.5 \\
\hline $\mathrm{CSO} 07$ & pKmg & 153 & 181 & 9 & 89 & 44 & 8 & 9 & 7 & 35.4 & 22.7 & 41.9 \\
\hline $11 \mathrm{SN} 40$ & pKmg & 167 & 194 & 40 & 63 & 33 & 0 & 2 & 1 & 36.0 & 22.2 & 41.8 \\
\hline CS06 & pKmg & 112 & 256 & 52 & 7 & 47 & 19 & 3 & 4 & 26.2 & 13.8 & 60.0 \\
\hline $11 \mathrm{SN} 38$ & $\mathrm{CM}$ & 150 & 216 & 29 & 37 & 46 & 14 & 3 & 5 & 34.7 & 15.3 & 50.0 \\
\hline 11SN39 & $\mathrm{CM}$ & 122 & 226 & 64 & 30 & 39 & 10 & 7 & 2 & 27.6 & 21.3 & 51.1 \\
\hline $11 \mathrm{SN} 41$ & $\mathrm{eKmg}$ & 100 & 215 & 0 & 85 & 62 & 23 & 12 & 3 & 25.0 & 21.3 & 53.8 \\
\hline $\mathrm{CS} 05$ & eKmg & 119 & 225 & 0 & 56 & 56 & 40 & 3 & 1 & 29.8 & 14.0 & 56.3 \\
\hline $11 \mathrm{SN} 37$ & Leucogranite & 176 & 167 & 142 & 11 & 3 & 0 & 0 & 1 & 35.5 & 30.8 & 33.7 \\
\hline \multicolumn{13}{|c|}{ Central Transect } \\
\hline $\mathrm{CS} 22$ & $\mathrm{eKmg}$ & 115 & 211 & 36 & 26 & 63 & 45 & 1 & 3 & 29.6 & 16.0 & 54.4 \\
\hline $\mathrm{CS} 26$ & $\mathrm{eKmg}$ & 91 & 236 & 18 & 43 & 75 & 34 & 1 & 2 & 23.5 & 15.7 & 60.8 \\
\hline $\mathrm{CS} 23$ & $\mathrm{eKmg}$ & 117 & 221 & 39 & 35 & 42 & 37 & 7 & 2 & 28.4 & 18.0 & 53.6 \\
\hline $\mathrm{CS} 25$ & $\mathrm{eKmg}$ & 145 & 198 & 37 & 40 & 42 & 30 & 3 & 5 & 34.5 & 18.3 & 47.1 \\
\hline $\mathrm{CS} 24$ & $\mathrm{eKmg}$ & 150 & 206 & 36 & 43 & 27 & 36 & 0 & 2 & 34.5 & 18.2 & 47.4 \\
\hline $\mathrm{CS} 21$ & eKmg & 101 & 217 & 49 & 41 & 56 & 31 & 1 & 4 & 24.8 & 22.1 & 53.2 \\
\hline CS16 & $\mathrm{eKmg}$ & 127 & 210 & 53 & 36 & 38 & 29 & 4 & 2 & 29.8 & 20.9 & 49.3 \\
\hline \multicolumn{13}{|c|}{ Southern Region } \\
\hline $\mathrm{CS} 12$ & $\mathrm{pKmg}$ & 145 & 237 & 27 & 27 & 45 & 11 & 2 & 6 & 33.3 & 12.4 & 54.4 \\
\hline CS10 & eKmg & 132 & 210 & 54 & 70 & 11 & 14 & 2 & 7 & 28.3 & 26.6 & 45.1 \\
\hline CS09 & Leucogranite & 166 & 185 & 70 & 51 & 23 & 0 & 1 & 4 & 35.2 & 25.6 & 39.2 \\
\hline
\end{tabular}


Each unit can be distinguished on a QAP diagram (Fig. 15), with decreasing abundance quartz and increasing plagioclase from porphyritic, to the granodiorite of Cow Meadow, to equigranular granodiorite. Samples on the northern margin make up the most mafic, and hornblende rich samples in their respective groups.

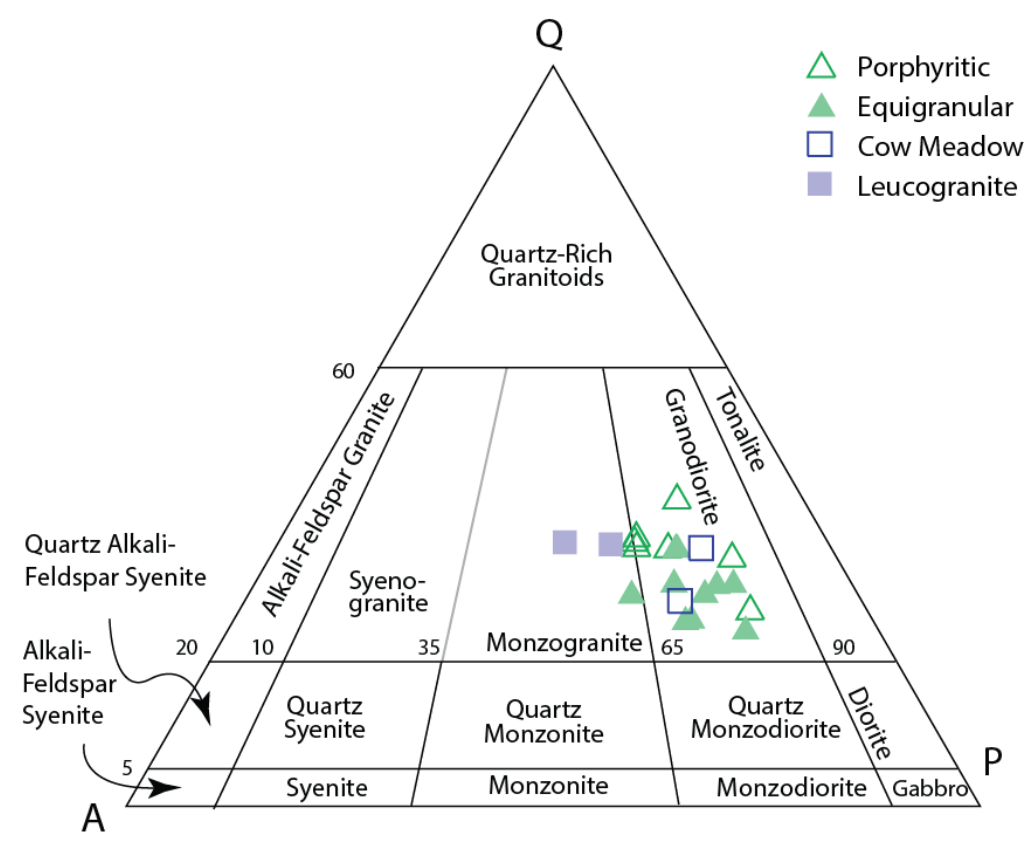

Figure 15. QAP diagram showing modal mineralogy of Mount Givens samples. After Streckeisen (1976).

The samples in the central transect differ from the equigranular samples of the north mostly in their mafic content (13-22\%), with higher proportions of hornblende (31$47 \%$ ) relative to biotite. Unlike the northern equigranular samples, K-felspars are more evenly divided between microcline and orthoclase.

Three representative samples were collected from the southern region for comparison to the north. CS12, the porphyritic sample collected from the western margin is fairly similar to the more mafic-rich porphyritic samples from the north. CS10, the 
representative equigranular sample is notably more felsic than northern and central equigranular samples (5\% mafic minerals); however it has one of the highest proportions of hornblende $(56 \%)$ in the pluton. The southern leucogranite is very similar to the aplite of Jackass Rock, although with a slightly lower percentage of K-feldspar.

\section{Whole Rock Geochemistry}

Samples, including compositional outliers, from the Mount Givens pluton range in $\mathrm{SiO}_{2}$ from 50-77\%. Major elements show largely linear trends on Harker diagrams (Fig. 16), with increased scatter apparent towards the more mafic end of the spectrum. Alkali elements show the most variation with $\mathrm{SiO}_{2}$. Trace elements also show largely linear trends on Harker diagrams (Fig. 17), although with increased scatter. A full table of whole rock geochemistry is provided in Appendix B.

All samples except the aplite of Jackass Rock show similar REE patterns, with LREE enrichment and very minor Eu anomalies (Fig. 18). REE concentrations generally decrease with increasing $\mathrm{SiO}_{2}$. The aplite of Jackass Rock has a strong depletion in MREE, causing a concave up pattern. This is consistent with titanite fractionation and has been observed in fine-grained leucogranites elsewhere in the Sierra Nevada batholith (Burgess and Miller, 2008; Glazner et al., 2008).

\section{Zircon Thermometry}

\section{Pluton-Wide Results}

Zircon saturation temperatures calculated using the reevaluated thermometer of Boehnke et al. (2013) range from 625 to $735^{\circ} \mathrm{C}$, significantly lower than all Ti-in-zircon temperatures. 

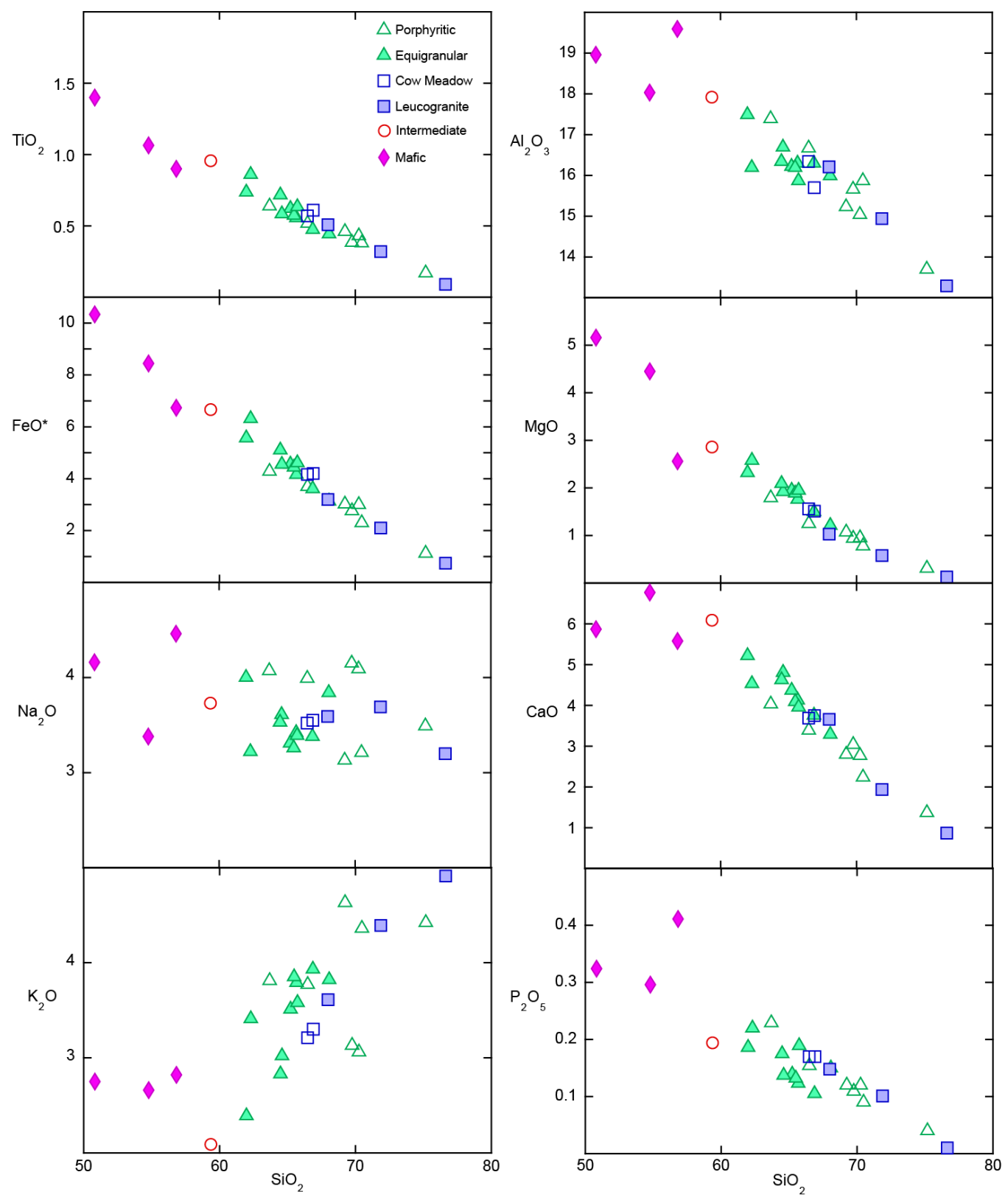

Figure 16. Whole rock major element geochemistry. 

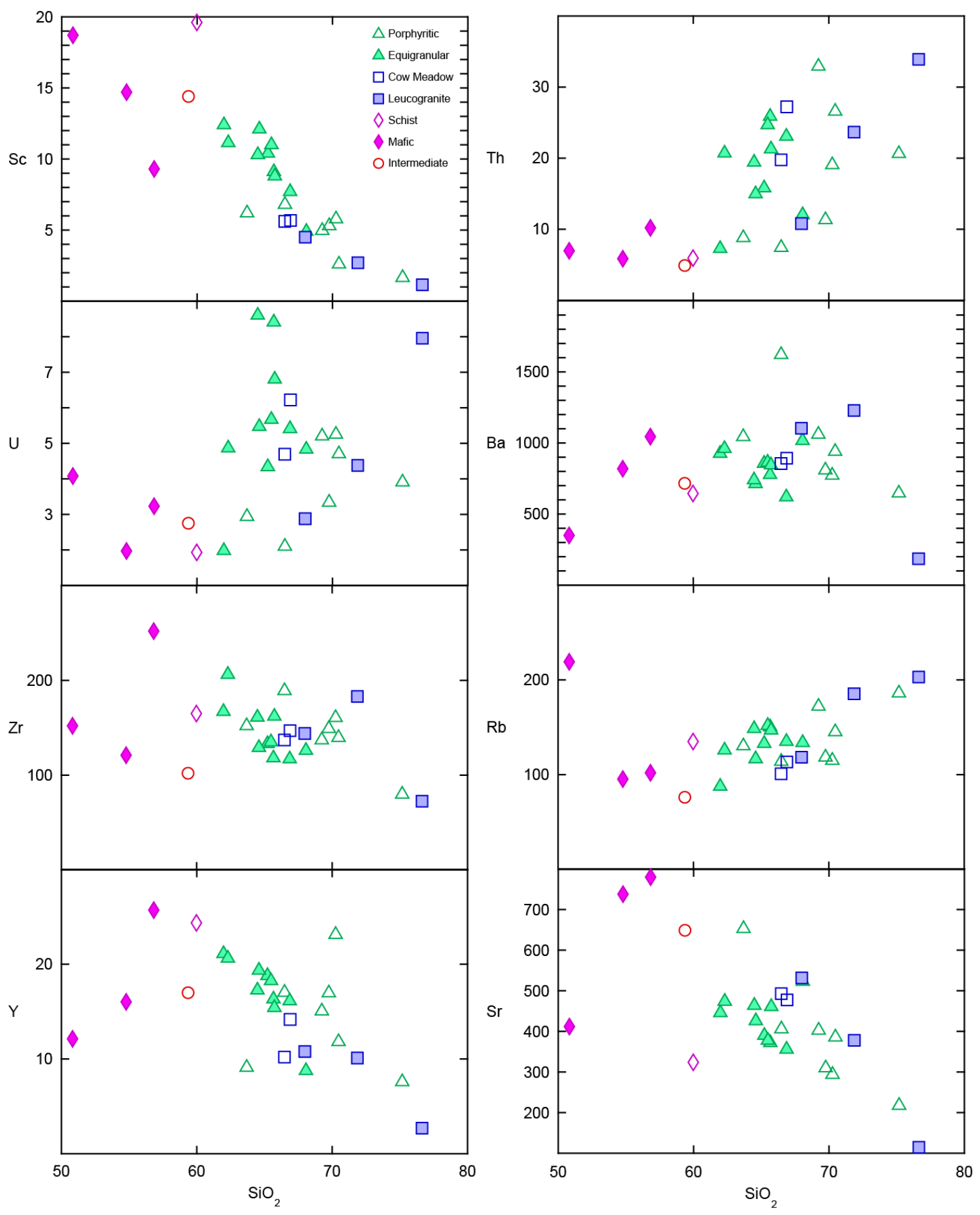

Figure 17. Whole rock trace element geochemistry. 


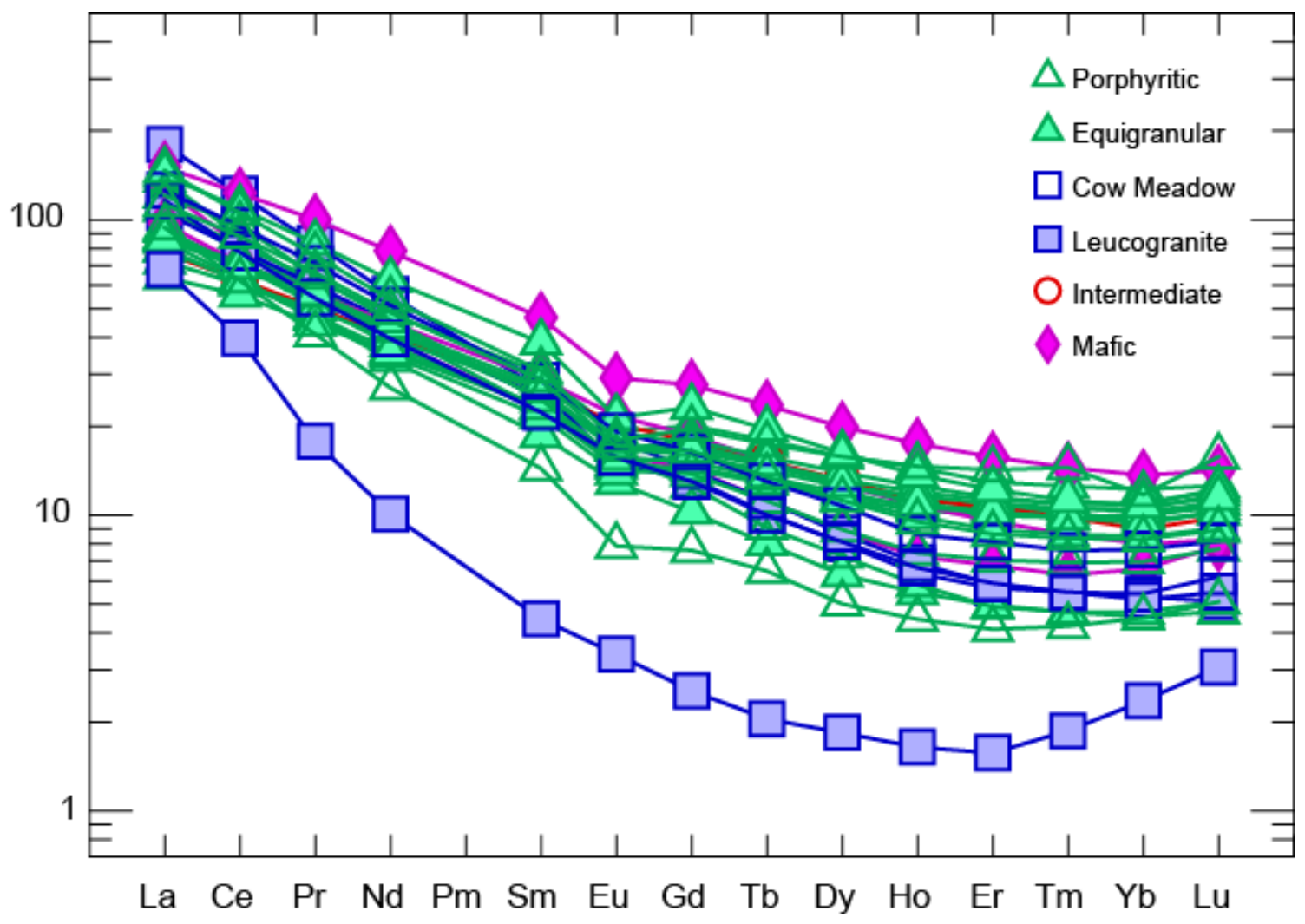

Figure 18. Chondrite normalized whole rock REE plots. All samples normalized using Sun and McDonough (1989).

Ti-in-zircon temperatures calculated from individual spot measurements $(\mathrm{n}=186)$ for all rock types range from $790-1070{ }^{\circ} \mathrm{C}$, with over $75 \%$ between 875 and $1000{ }^{\circ} \mathrm{C}$ (Fig. 19). Figure 20 shows temperature distributions for each rock type, and slight differences in range are evident. Porphyritic samples have a lower average temperature than equigranular ones, extending down to $800{ }^{\circ} \mathrm{C}$. The granodiorite of Cow Meadow has a noticeably cooler and more restricted temperature profile than the other major rock units. The interior aplite of Jackass Rock ranges to some of the lowest temperatures recorded in the pluton. Both the mafic and felsic units in the central region have relatively restricted, high temperatures. 


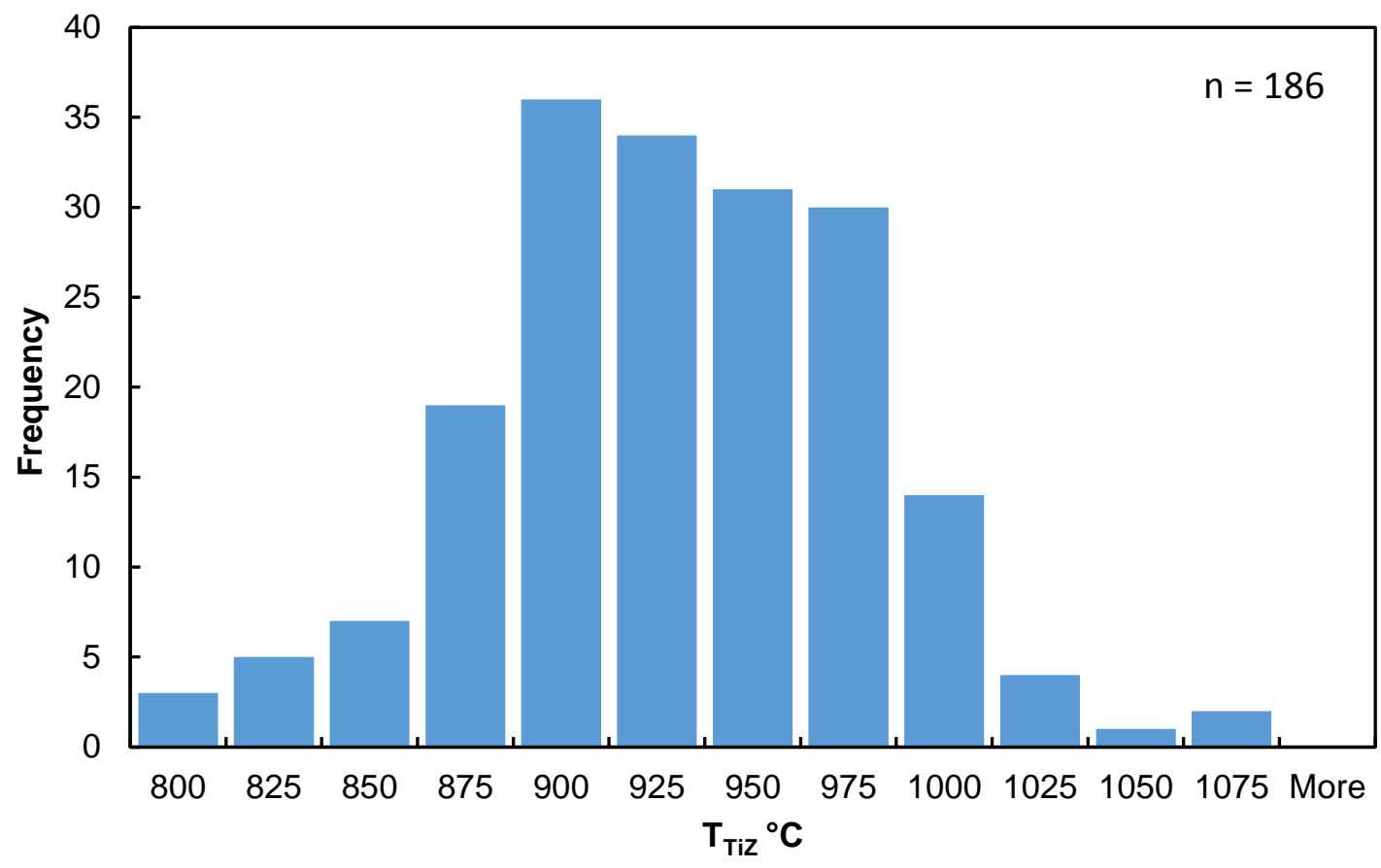

Figure 19. Histogram of calculated Ti-in-zircon temperatures for entire sample suite. Calculated zircon saturation temperatures are between 625 to $735{ }^{\circ} \mathrm{C}$. 


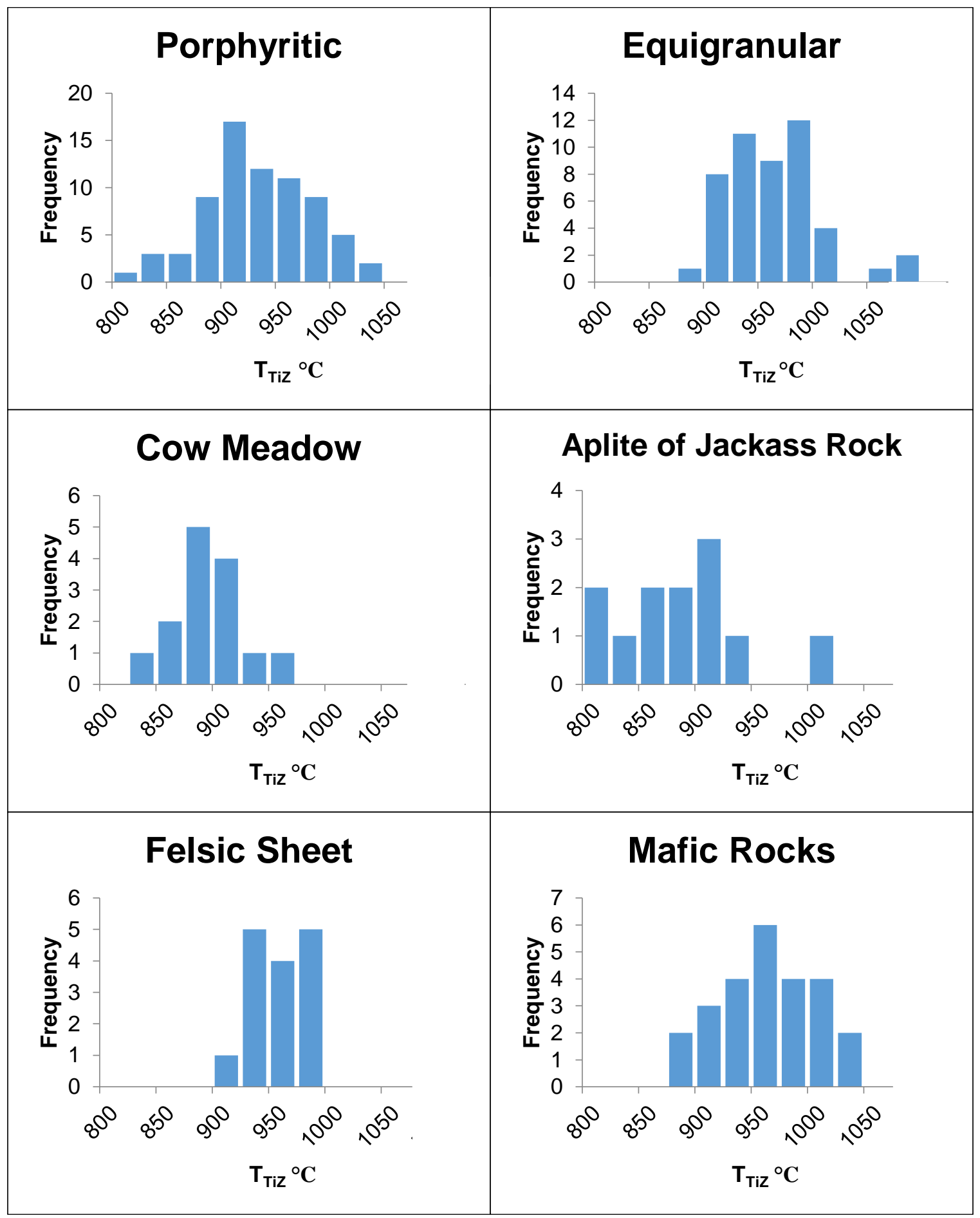

Figure 20. Ti-in-zircon $\left(\mathrm{T}_{\mathrm{tiz}}\right)$ temperature profiles for different rock types. 
In the northern lobe, temperatures decrease inwards, with the aplite of Jackass Rock reaching the lowest temperatures (Fig. 21). Sample CS07 is widely variable in temperature and falls off the general trend of the northern samples, with a third of analyses reaching below the lowest temperature measured for the outer equigranular unit. Temperatures on the outer western part of the pluton reach higher temperatures than those in the east. It is uncertain whether this is due to a geographical effect, or is related to textural differences.

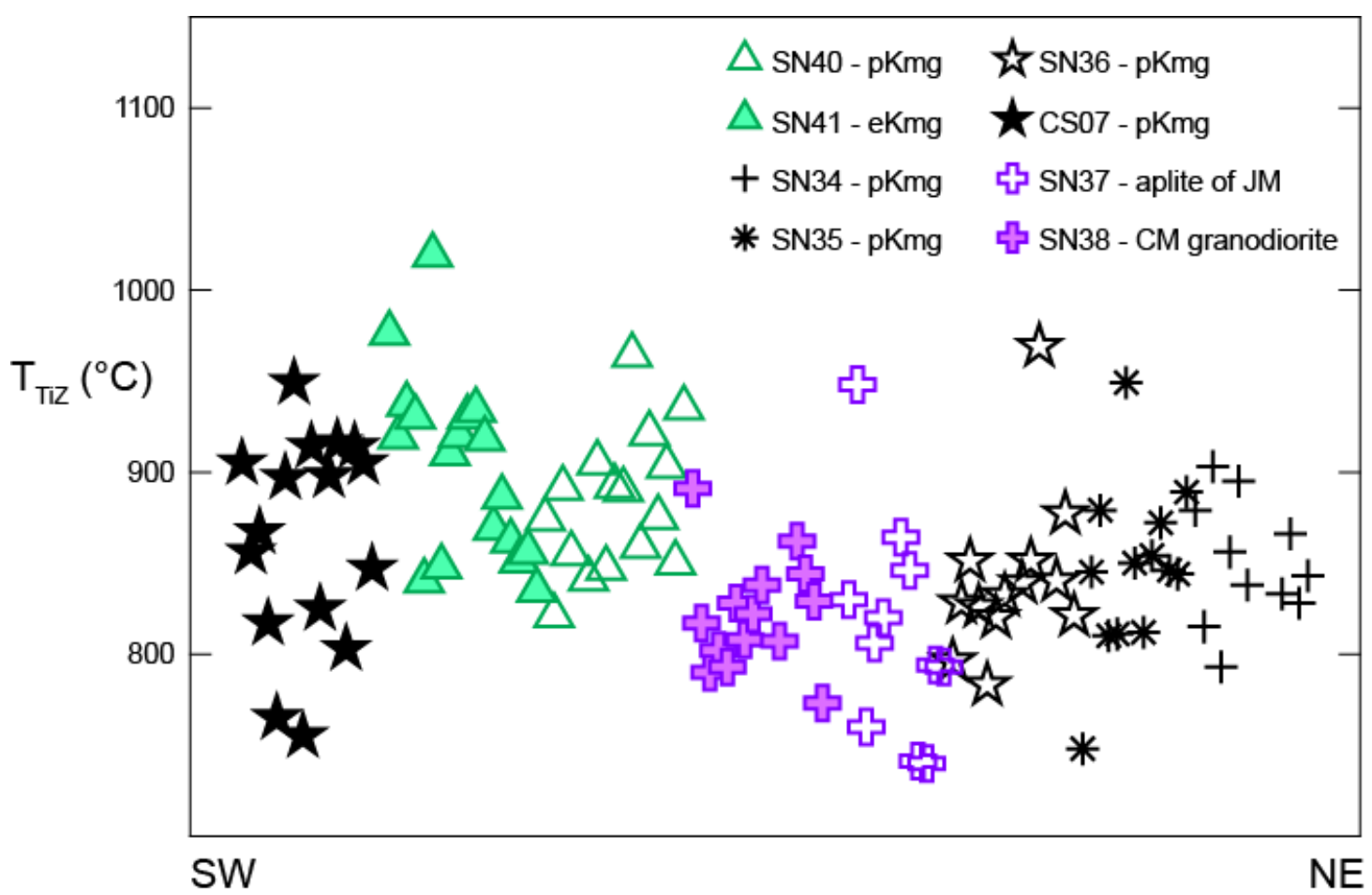

Figure 21. Schematic zircon temperature profile across northern lobe (see Fig. 5). Note, sample CS07 falls much farther north than the rest of the samples on the transect. pKmgporphyritic Mount Givens granodiorite; eKmg- equiganular Mount Givens granodiorite; JM- Jackass Meadow; CM- Cow Meadow. 


\section{Intergrain Variations}

Temperature variations among zircons in samples ranges from $70{ }^{\circ} \mathrm{C}$, in the central granodiorite, to $200{ }^{\circ} \mathrm{C}$, in the aplite of Jackass Rock (Figs. 22-24). In some cases this dispersion is accounted for mainly by one outlier; for instance the aplite of Jackass Rock has a single temperature analysis at $998^{\circ} \mathrm{C}$, while the rest of the analyses are between 791 and $914{ }^{\circ} \mathrm{C}$. All but one of these high temperature outliers are cores, suggesting that a small portion of zircon growth began at high temperatures $\left(>950{ }^{\circ} \mathrm{C}\right)$, or that high-temperature zircons were entrained in the main melt. However, other samples, such as CS07, with large degrees of variation show a continuous range of temperatures.

\section{Intragrain Variations}

Intragrain temperature variations exist in most samples (Figs. 22-24). The greatest amount of intragrain variability is in sample 11SN40, where six of seven zircons analyzed have over a $35^{\circ} \mathrm{C}$ difference between core and rim. In the northern lobe, the innermost samples show the least degree of intragrain variation. Among samples with temperature variation, most contain at least one grain with a reversed temperature gradient. Samples 11SN34 and 11SN35, in the northeast corner of the northern lobe are the only two samples that show significant temperature gradients that are all normally zoned. 

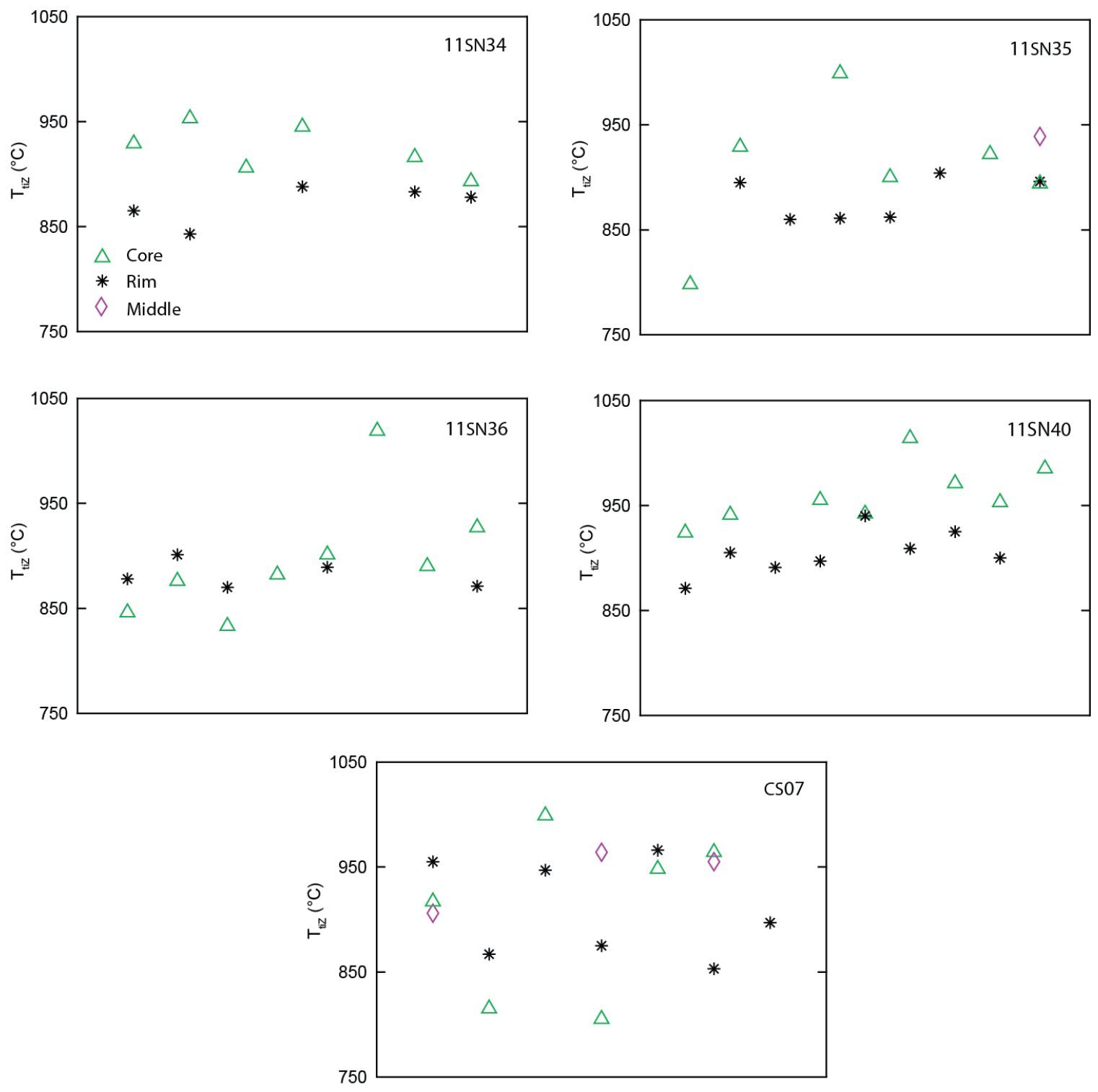

Figure 22. Ti-in-zircon temperature measurements for porphyritic samples. 

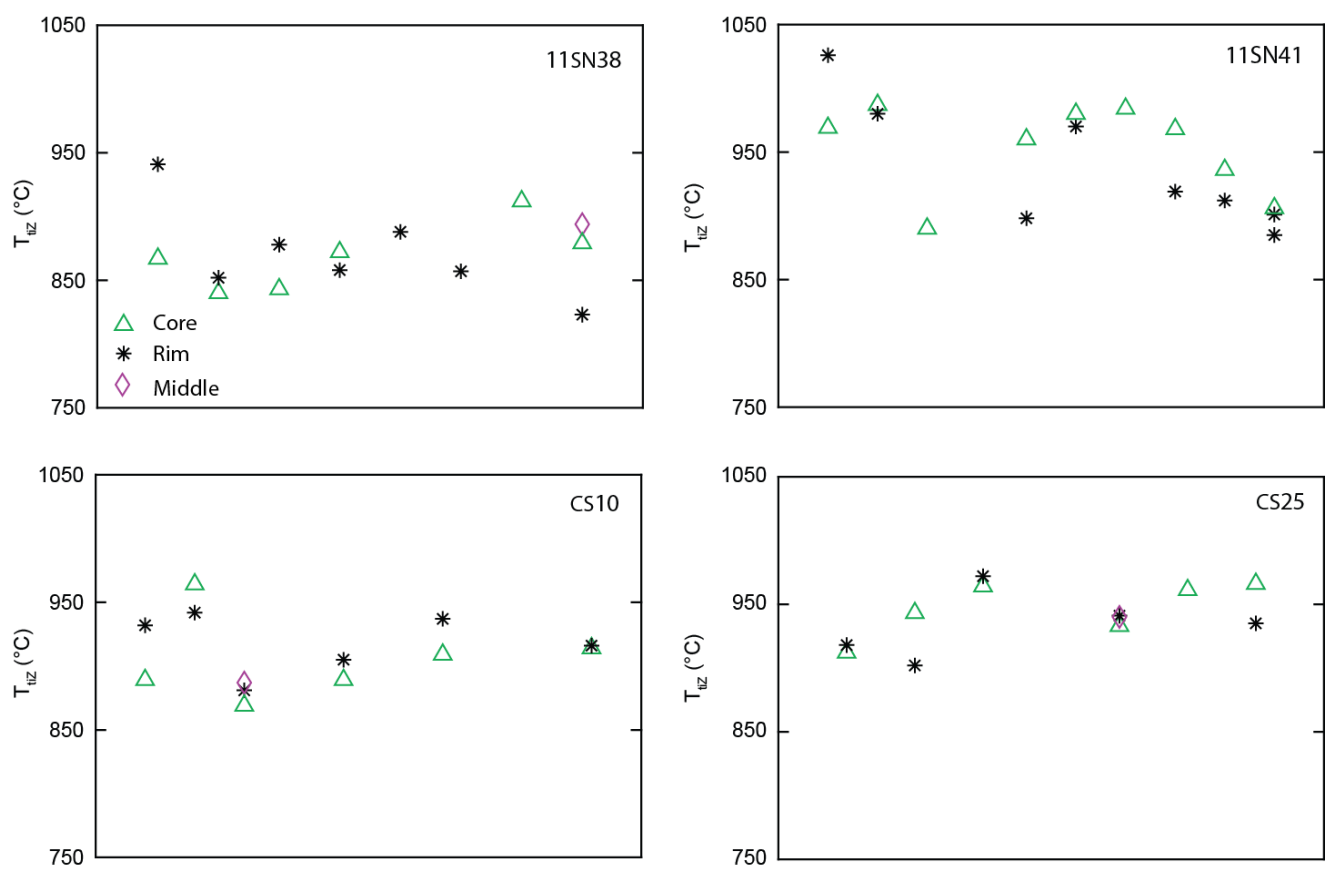

Figure 23. Ti-in-zircon temperature measurements for equigranular samples.
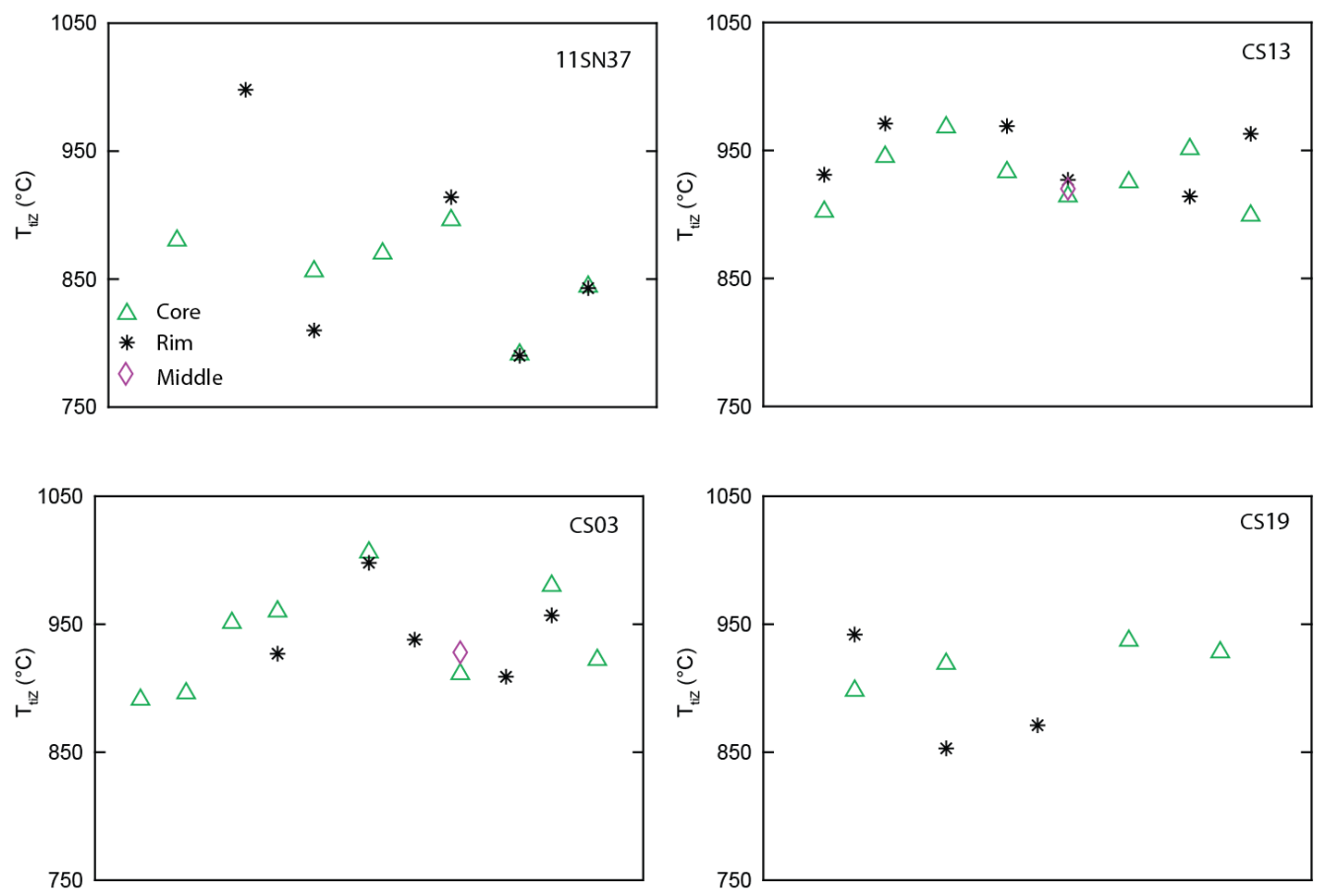

Figure 24. Ti-in-zircon temperature measurements for compositional outliers: aplite of Jackass Rock (11SN37), felsic sheet (CS13), and mafic samples (CS03 and CS19). 


\section{Zircon Geochemistry}

Trends in zircon geochemistry are consistent throughout the entire Mount Givens sample suite, despite appreciable scatter in trace element values and ratios. All analyses plot along common trends on trace element diagrams (Figs. 25-28). Hf exhibits a positive correlation with $\mathrm{Yb} / \mathrm{Gd}$, and negative correlations with $\mathrm{Ti}, \mathrm{Eu} / \mathrm{Eu}^{*}$ and $\mathrm{Th} / \mathrm{U}$. All trends are consistent with zircon crystallization, and do not indicate the onset of any other mineral exerting trace element control during zircon growth. The trace element fields of cores and rims overlap completely for all of these plots (Figs. 25-28). REE patterns for all samples are typical of igneous zircon, showing concave down shapes, strong HREE-enrichment, and pronounced positive Ce and negative Eu anomalies (Fig. 29).

Trace elements concentrations and REE trends in the Mount Givens pluton do not correlate to rock texture. Both porphyritic and equigranular samples span most of the range of trace elements measured for the entire pluton (Figs. 25-28). The granodiorite of Cow Meadow is the most geochemically distinct unit in the pluton. As is shown in Figures 25-28, analyses from these samples are tightly clustered on trace element plots. The unit follows similar fractionation trends, but has restricted low values of $\mathrm{Hf}$, Ti, and $\mathrm{Th} / \mathrm{U}$, and high $\mathrm{Yb} / \mathrm{Gd}$.

The range of most trace element values and ratios remains consistent throughout the lifespan of the pluton (Figs. 30-34). The clear exception to this is Eu/Eu*, which is consistently higher in samples older than 95 Ma. Post-95 Ma samples also have Th/U ratios that reach significantly higher values than pre-95 Ma samples. 


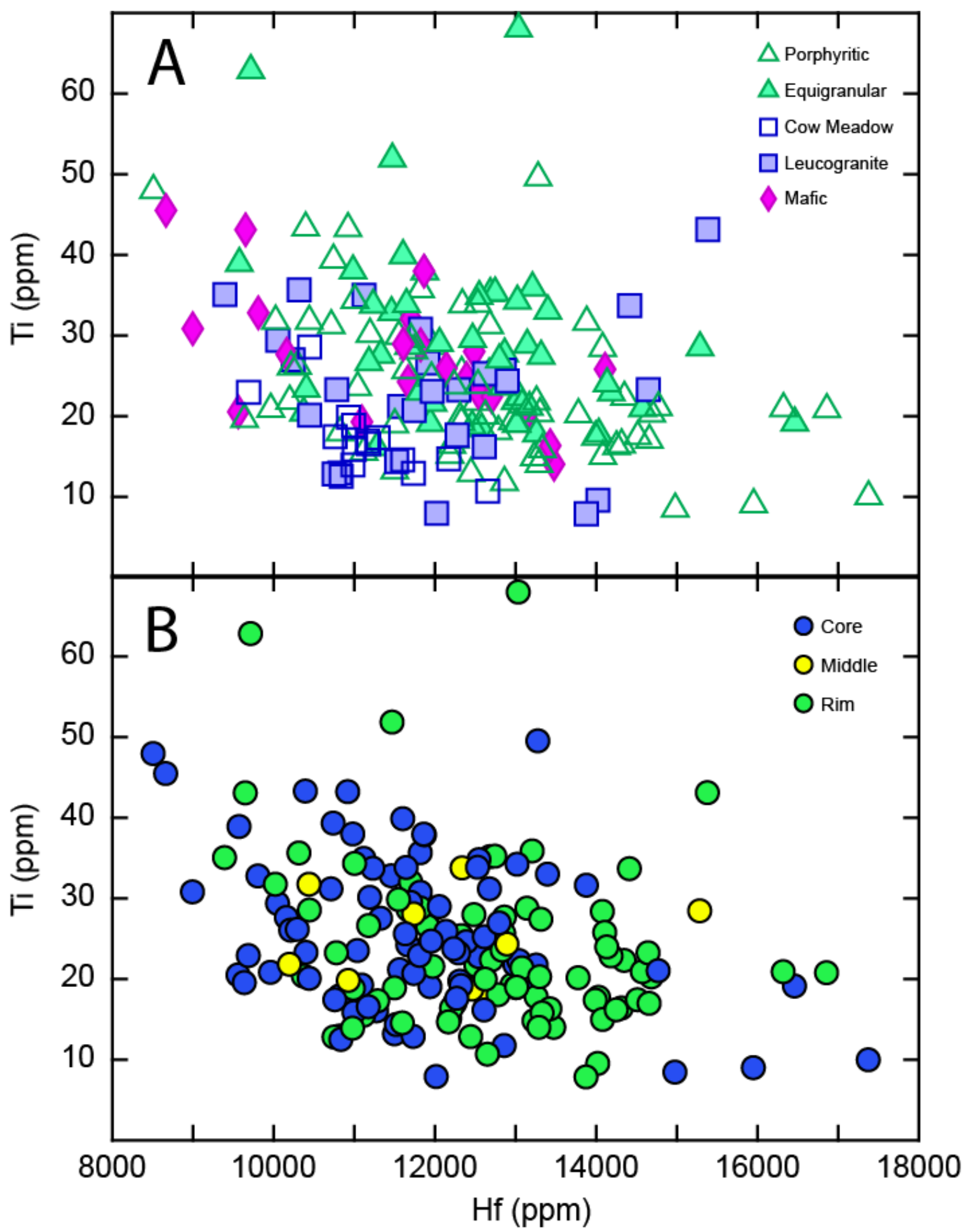

Figure 25. Ti vs. Hf plots. (a) By rock type. (b) By spot location in zircon. 


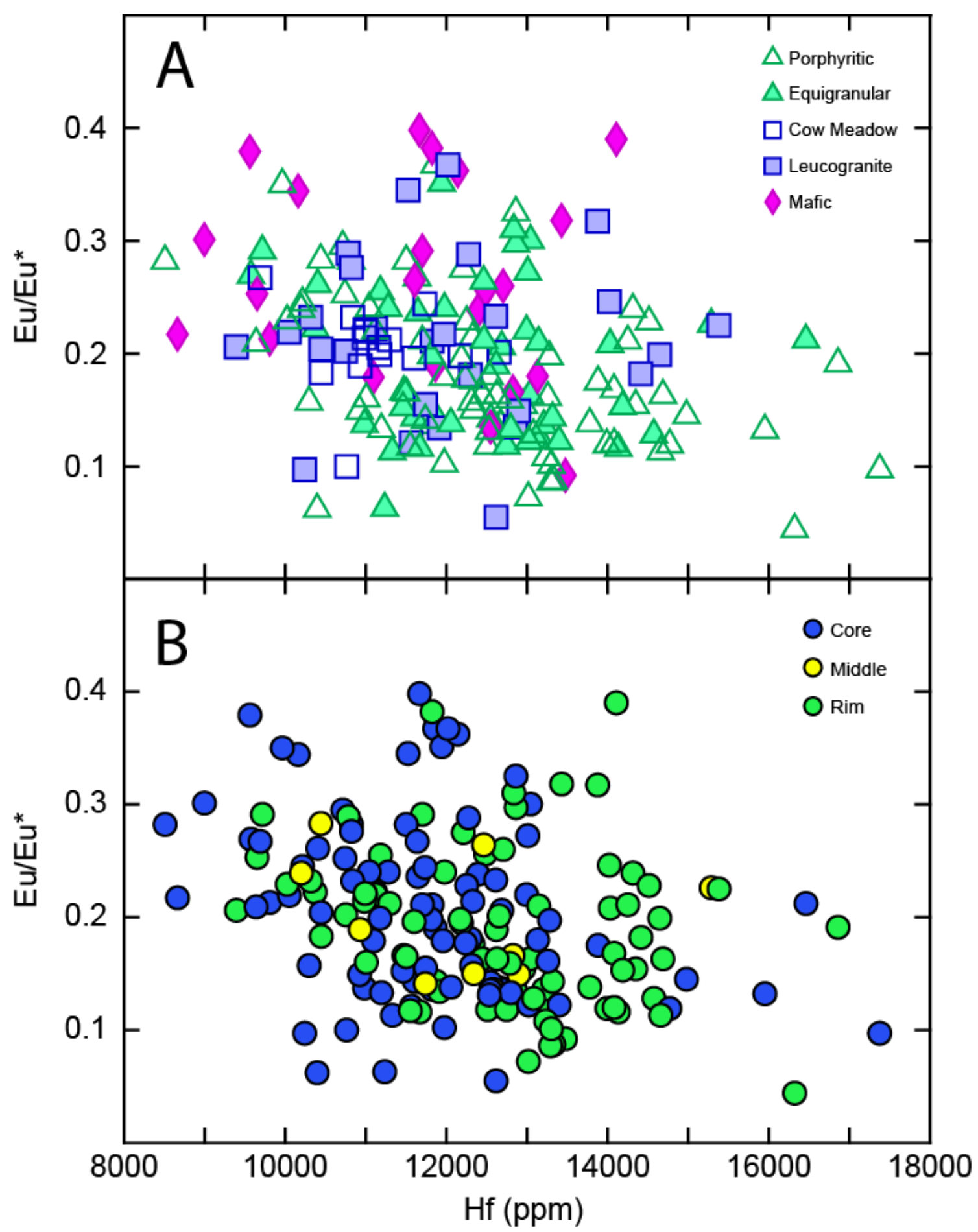

Figure 26. Eu/Eu* vs Hf plots. (a) By rock type. (b) By spot location in zircon. 


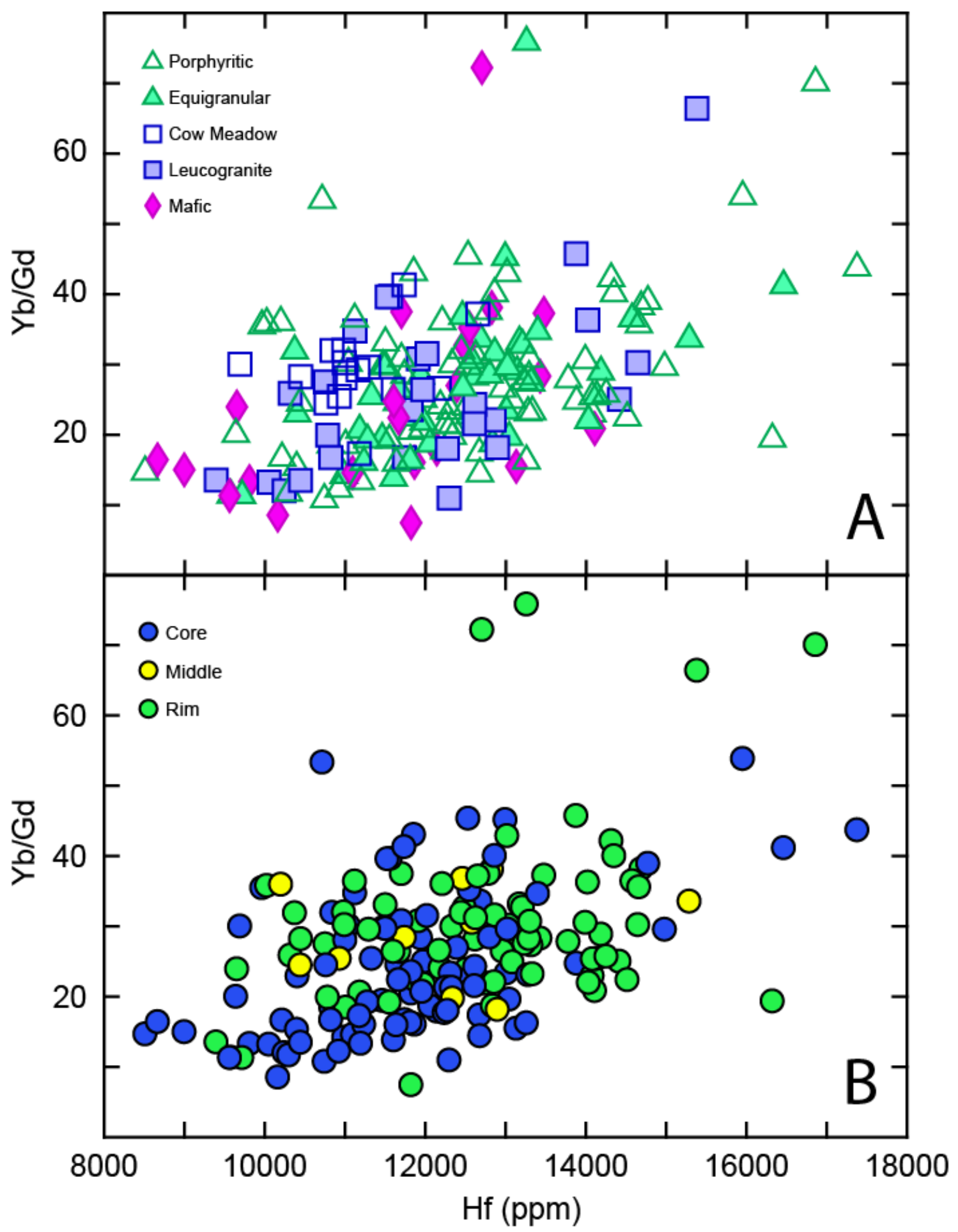

Figure 27. Yb/Gd vs. Hf plots. (a) By rock type. (b) By spot location in zircon. 


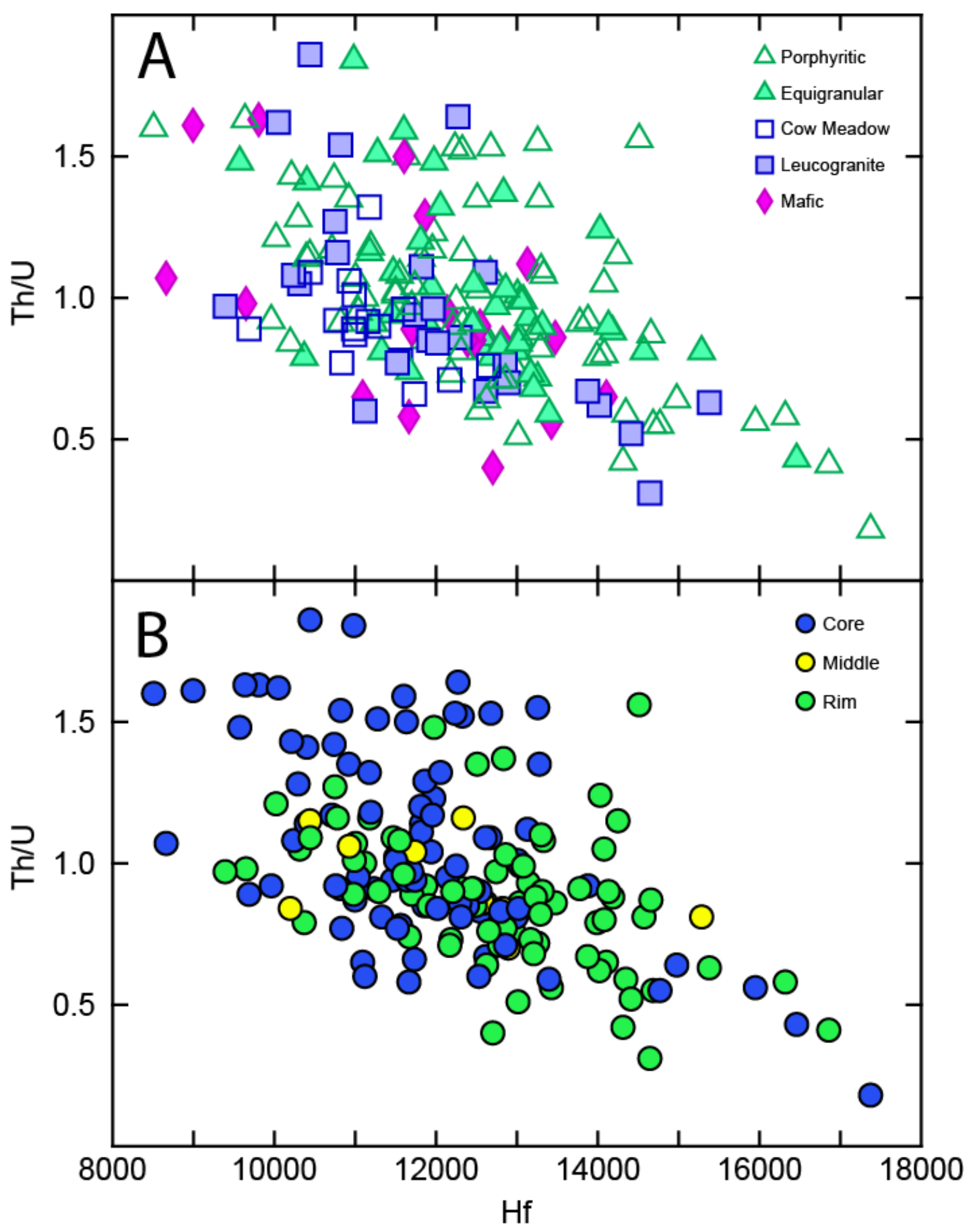

Figure 28. Th/U vs. Hf plots. (a) By rock type. (b) By spot location in zircon. 

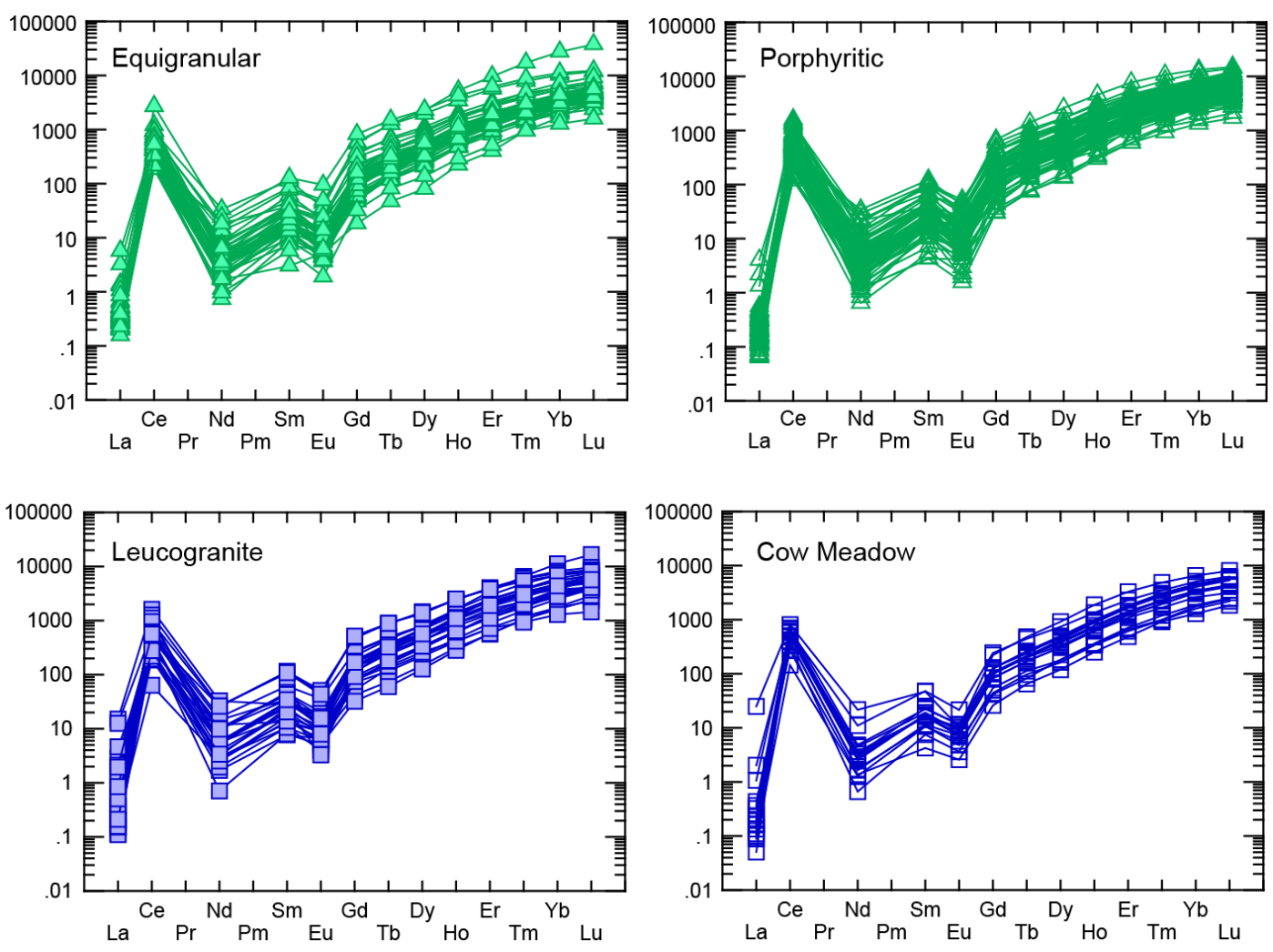

Figure 29. REE in zircon plots separated by rock type. All samples normalized using Sun and McDonough (1989).

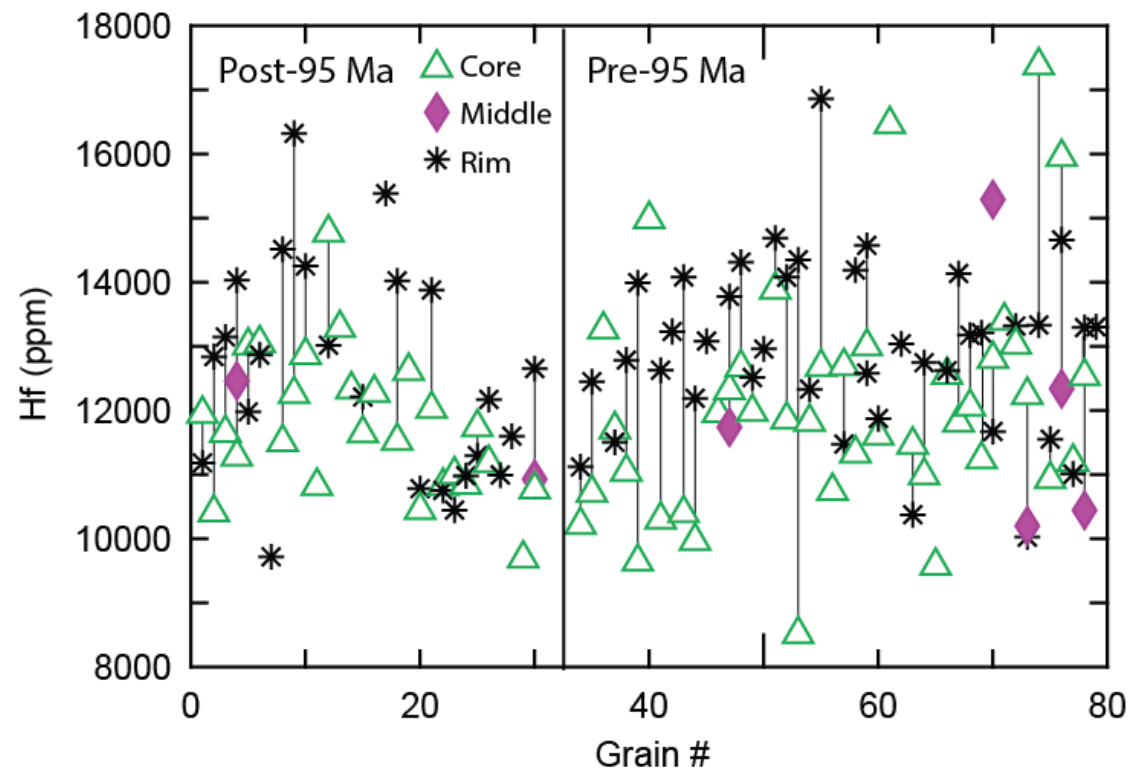

Figure 30. Rank order plot of zircon Hf concentration. Lines connect analysis spots from the same crystal. 


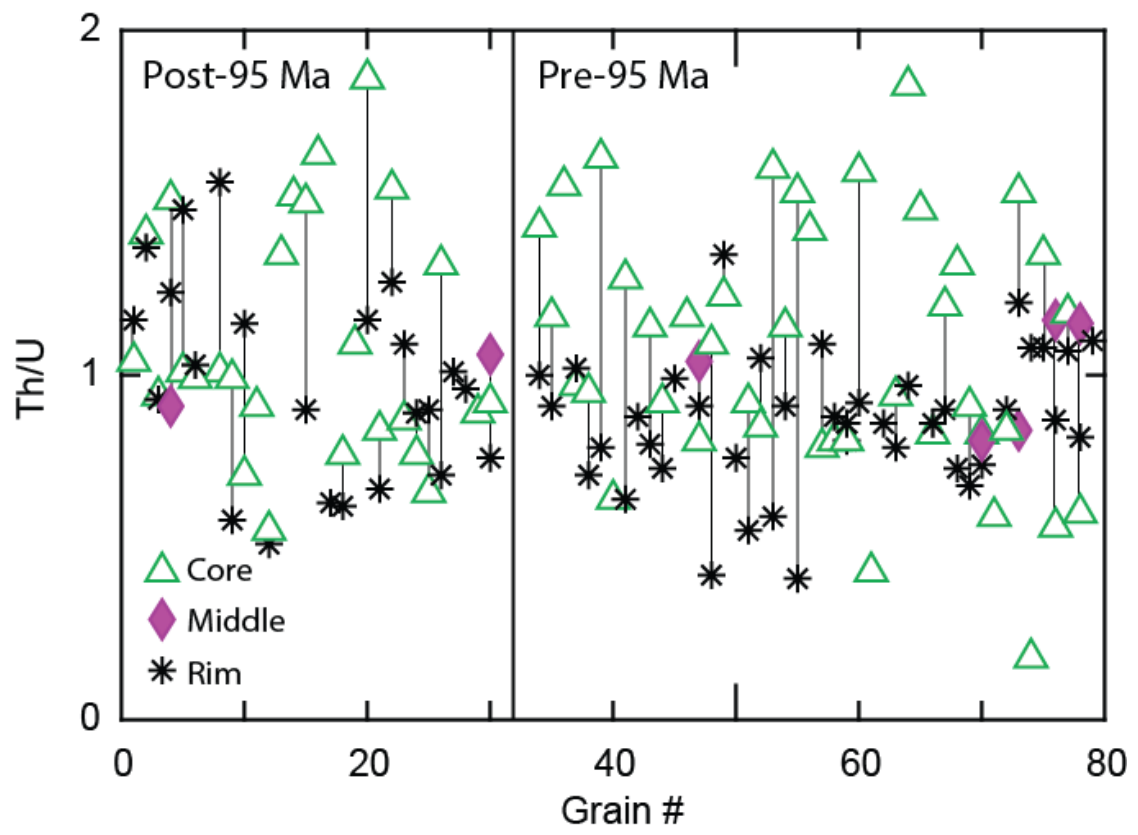

Figure 31. Rank order plot of zircon Th/U. Lines connect analysis spots from the same crystal.

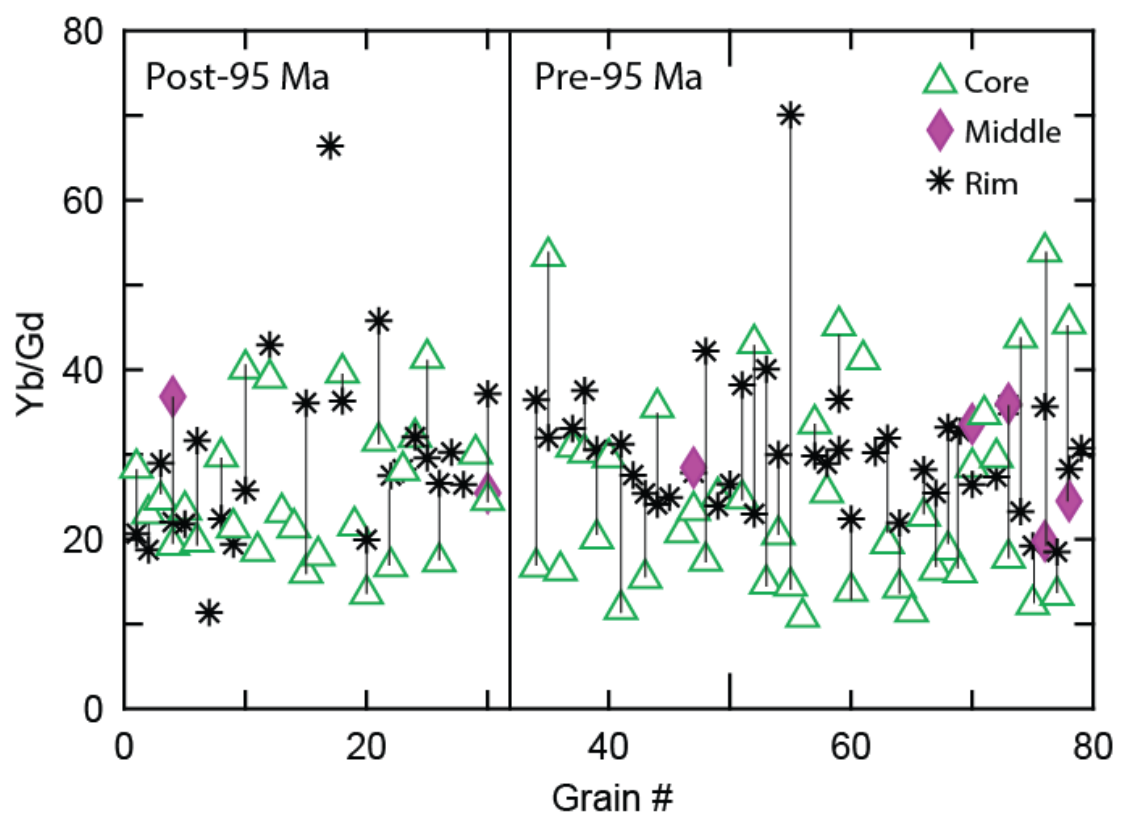

Figure 32. Rank order plot of zircon $\mathrm{Yb} / \mathrm{Gd}$. Lines connect analysis spots from the same crystal. 


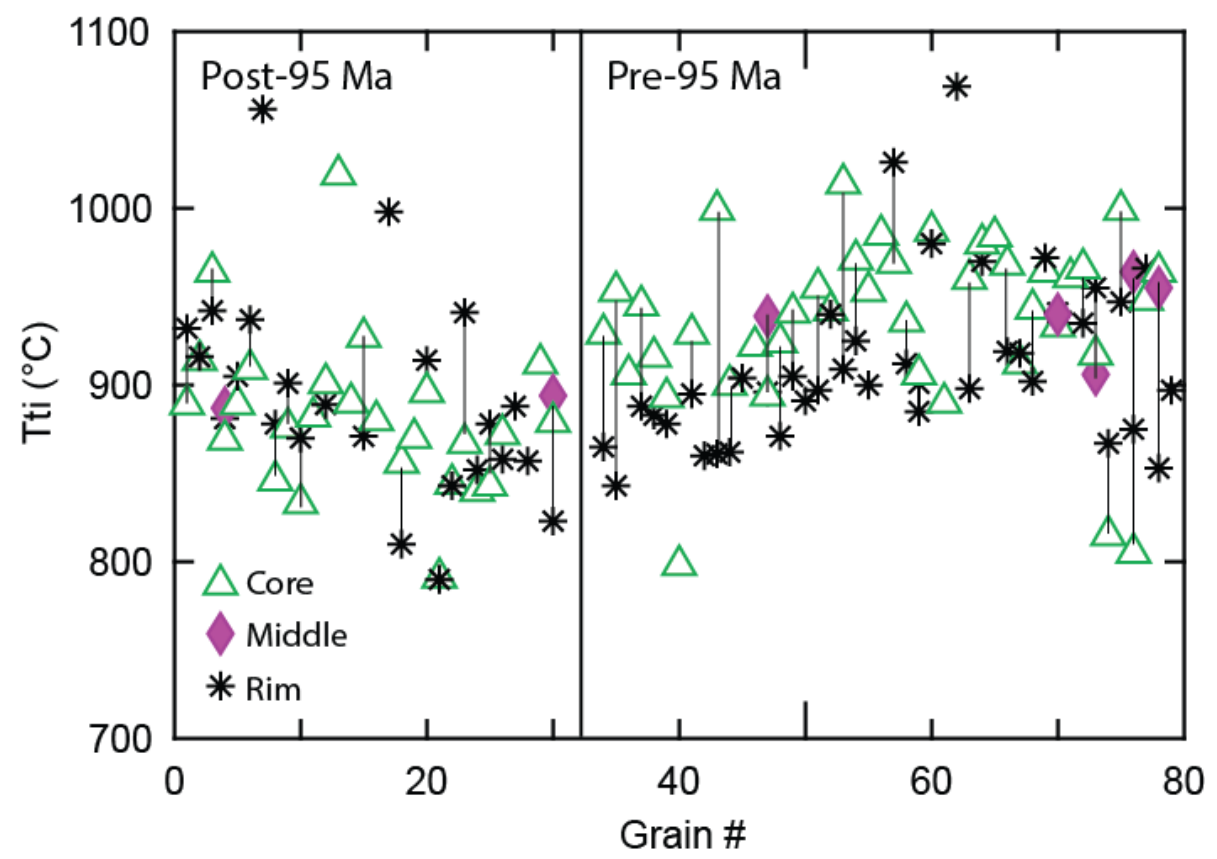

Figure 33. Rank order plot of calculated Ti-in-zircon temperatures. Lines connect analysis spots from the same crystal.

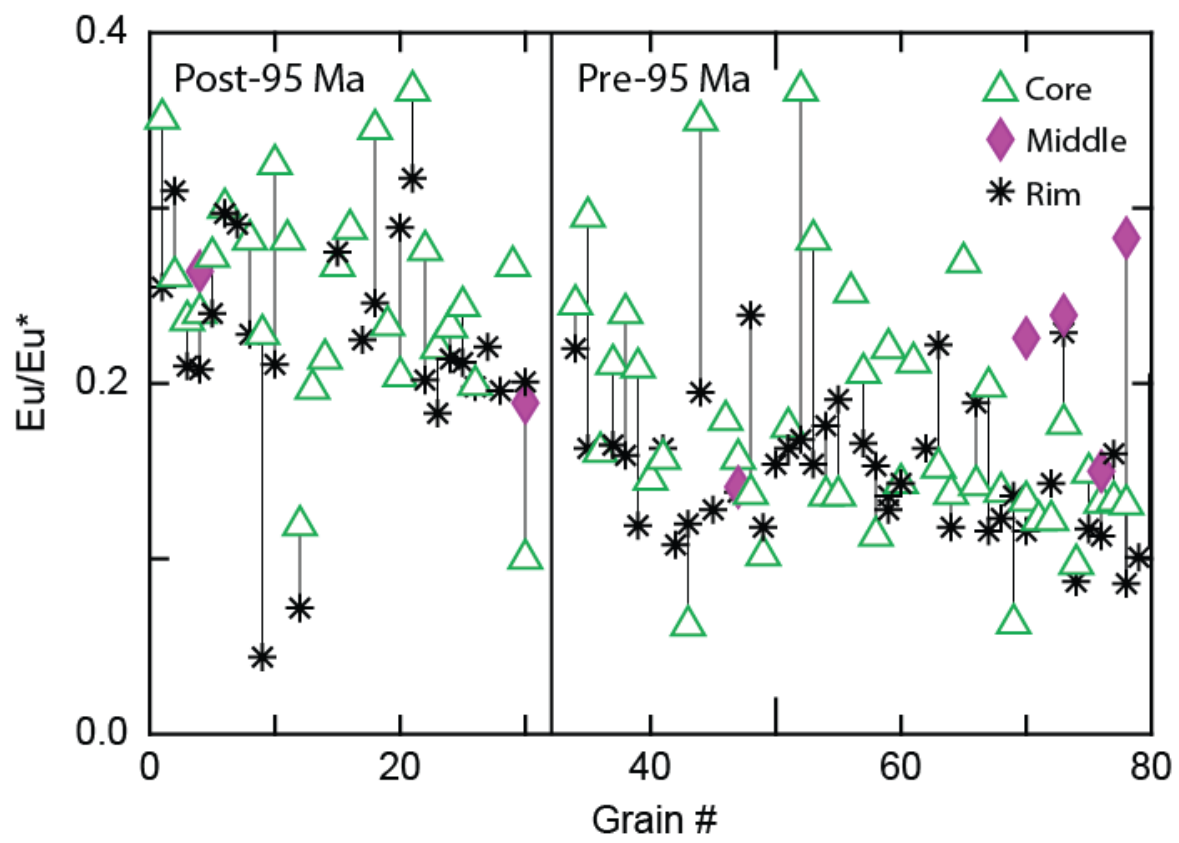

Figure 34. Rank order plot of zircon Eu/Eu*. Lines connect analysis spots from the same crystal. 


\section{Intercrystalline Variations}

As has been found in other studies (e.g. Claiborne et al, 2010), variation in zircon trace element signatures within individual samples often approaches the total variation within the pluton. The amount of intercrystal variation does not correlate with spatial location within the pluton, age, or rock type (Figs. 25-28). Sample CS10 has the greatest variation in $\mathrm{Yb} / \mathrm{Gd}(31)$ and $\mathrm{Eu} / \mathrm{Eu}^{*}(0.249)$, as well as a fairly high $\mathrm{T}_{\mathrm{Tiz}}$ variation (94 ${ }^{\circ} \mathrm{C}$ ), although Hf variation is among the lowest of any measured samples (2158 ppm; see Appendix E). Both the central granodiorite (CS25) and the granodiorite of Cow Meadow (11SN38) show little variation, and are tightly clustered on most trace element plots (Figs. 25-28).

\section{Intracrystalline Variations}

As with temperature, variations in trace elements within crystals are common in the zircon populations of all samples (Figs. 30-34). Hf is largely anti-correlated with Ti concentration and temperature; however, in some samples zircons that are reversely zoned in temperature are still normally zoned in Hf. In general, $\mathrm{Yb} / \mathrm{Gd}$ and $\mathrm{Eu} / \mathrm{Eu} *$ increase from core to rim, while $\mathrm{Th} / \mathrm{U}$ decreases, consistent with typical fractionation trends (Barth and Wooden, 2010; Claiborne et al., 2010). However, there are many examples of the reverse occurring for each particular element, and nearly all samples contain zircon crystals that show reverse zonation in multiple trace element values and ratios (Fig. 35). 


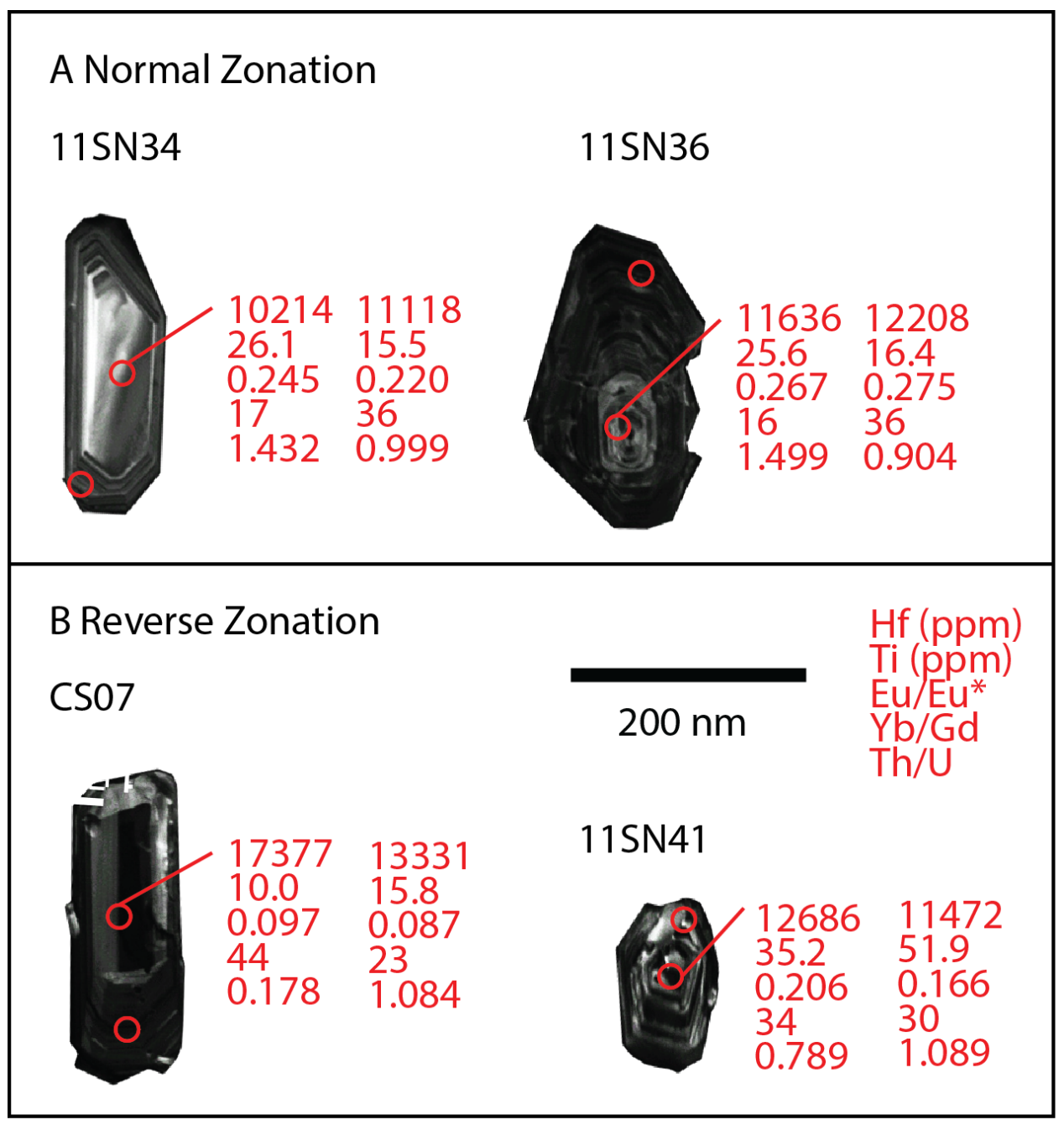

Figure 35. Intracrystalline variation in zircon trace elements. (a) Zircons that show normal, down-temperature fractionation patterns. (b) Zircons that show reverse zonation in trace elements.

\section{Isotopic Data}

The $\mathrm{O}$ and $\mathrm{Hf}$ isotopic systems in the Mount Givens pluton are broadly correlated (Fig. 30). The spread in isotopic data is significantly larger than the 2SD for both systems, indicating that variation is geologically significant. The isotopic composition of the mafic body in the southeast portion of the Mount Givens is constrained to low $\delta^{18} \mathrm{O}$ 
(5.3-6.0\%, except for one 6.6\%o core) and high $\varepsilon \mathrm{Hf}(2.2-8.5)$. A biotite schist, located on the western margin of the northern lobe, was sampled as a possible crustal endmember. Values of $\delta^{18} \mathrm{O}$ in the schist spans the observed variation in the Mount Givens plutonic samples, but $\mathrm{Hf}$ isotopic values are in the upper range of those measured in the pluton.

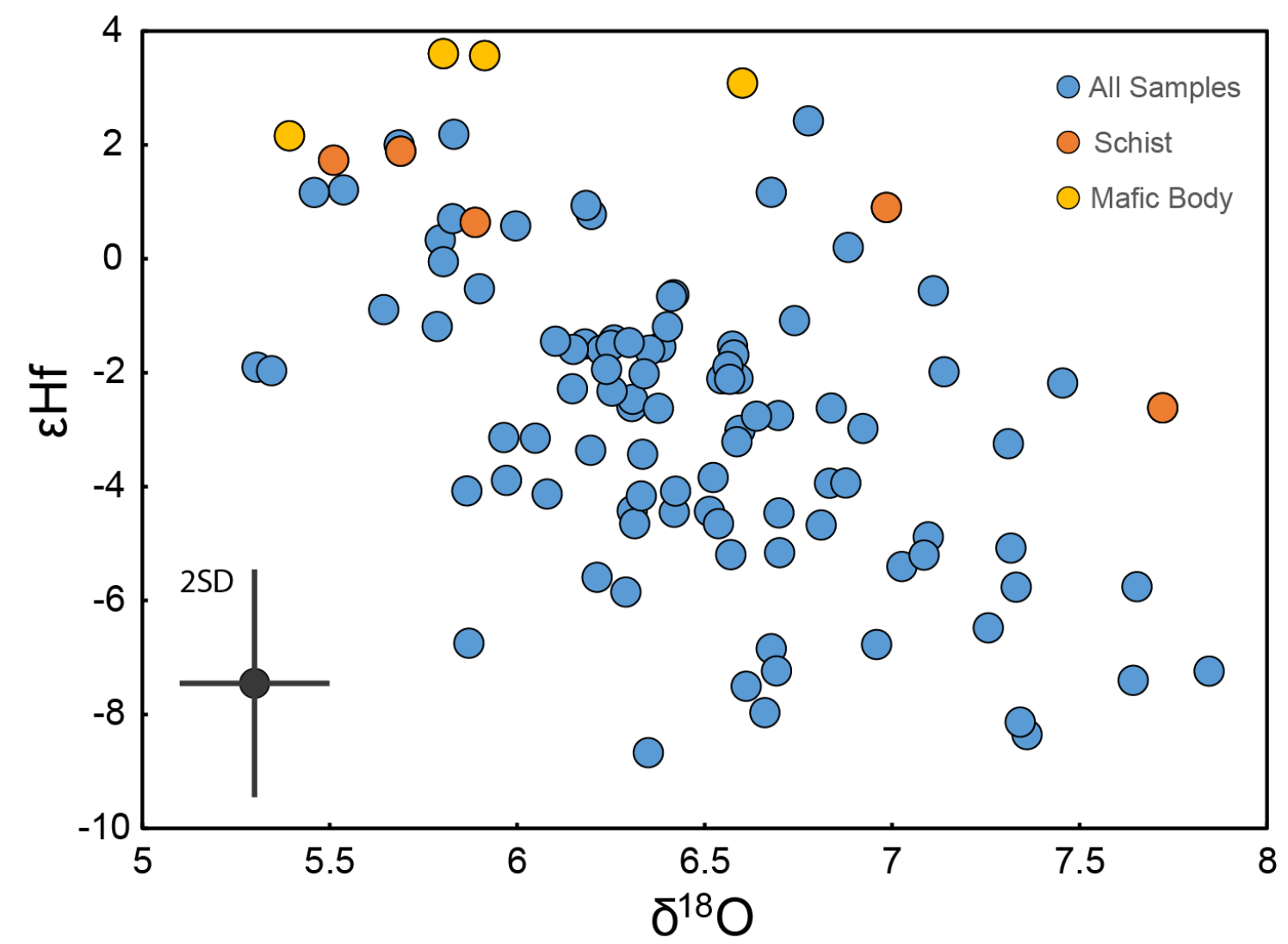

Figure 36. O vs Hf covariation plot. The data show a broad anticorrelation of $\varepsilon \mathrm{Hf}$ and $\delta^{18} \mathrm{O}$ values.

Both $\delta^{18} \mathrm{O}$ and $\varepsilon \mathrm{Hf}$ show no correlation with bulk rock $\mathrm{SiO}_{2}$ (Fig. 31). This indicates that isotopic variation in the pluton is not strongly dependent on the compositional evolution of the magma. 


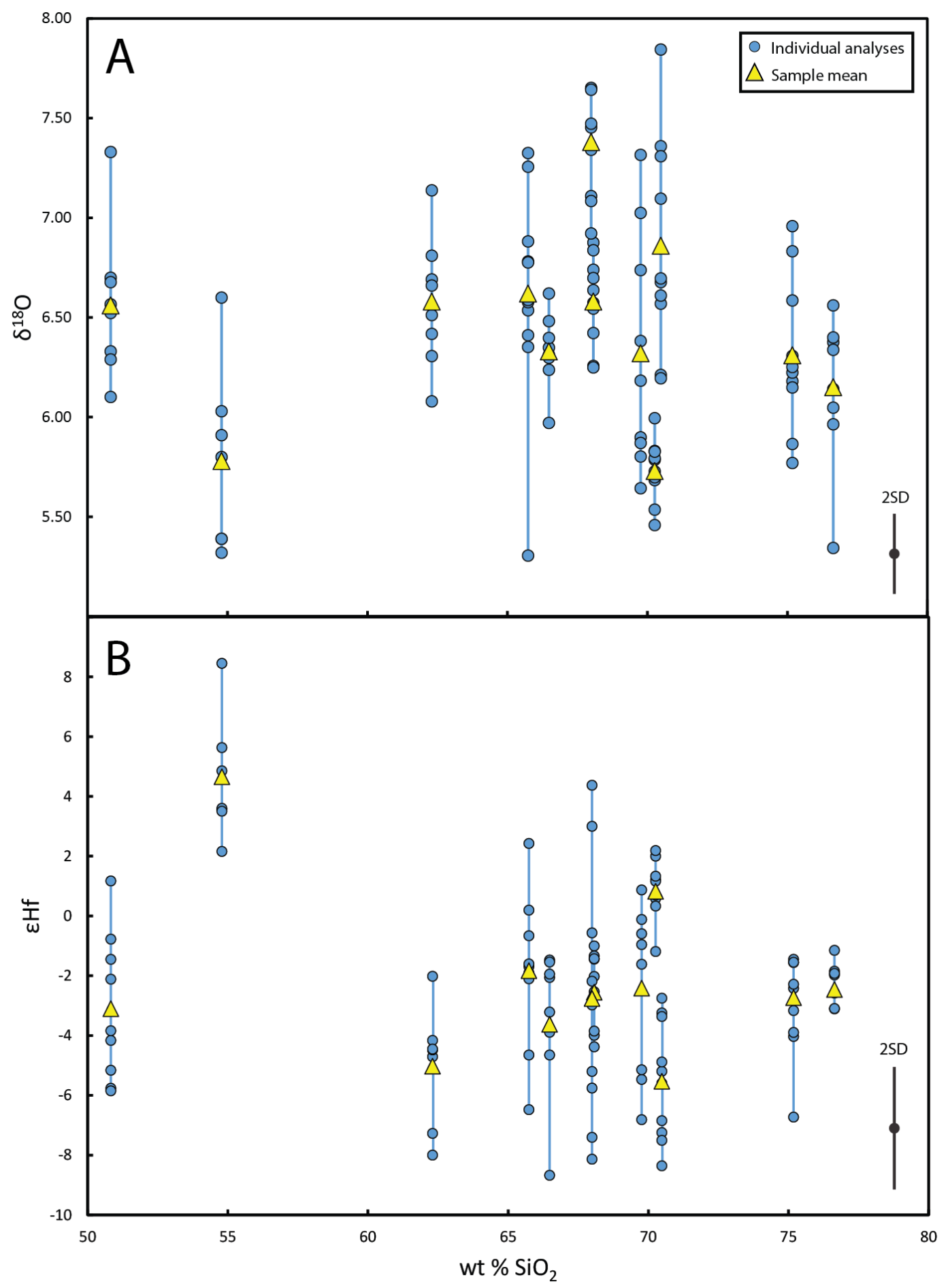

Figure 37. Variation of isotopes with bulk rock composition. (a) $\mathrm{O}$ values. (b) Hf values. Blue dots and connecting lines show individual analyses for each sample. Yellow triangles show the sample mean. 


\section{Longitudinal Variation}

Zircons from the Mount Givens pluton exhibits longitudinal variation in both isotopic systems, with a general pattern of increasing $\delta^{18} \mathrm{O}$ and decreasing $\varepsilon \mathrm{Hf}$ moving westwards towards the proposed Panthalassan-North American lithospheric boundary (Fig. 32). Figure 32 shows the relationship between geographic location and isotopic composition for all analyzed samples. The $\mathrm{x}$-axis displays the shortest distance between each sample's location and the Panthalassan-North American boundary of Lackey et al. (2008). Because of the uncertainty in the location of this boundary, generally the western edge of the Mount Givens pluton, the distance from the boundary measurements should not be viewed as exact. This trend is in agreement with multi-grain laser fluorination $\mathrm{O}$ isotope data from a previous study in the pluton (Lackey et al., 2008).

The two samples that most clearly differ from the zircon isotopic pattern are compositional outliers from the central region of the pluton. The sampled mafic body (CS19) has an average zircon $\delta^{18} \mathrm{O}$ of $5.78 \%$ and zircon $\varepsilon \mathrm{Hf}$ ranging from 2-8.5, showing its strong affinity with the mantle. The $\mathrm{O}$ and $\mathrm{Hf}$ isotopic composition of zircon from the felsic sheet (CS13) are noticeably high in $\delta^{18} \mathrm{O}$ and have a wide range of $\varepsilon \mathrm{Hf}$ (although both analyses with positive $\varepsilon \mathrm{Hf}$ are from a single zircon crystal). West of the boundary, sample CS07 displays wide variations in zircon O and Hf isotopic ratios, reaching towards more mantle-like values in both isotopic systems. 


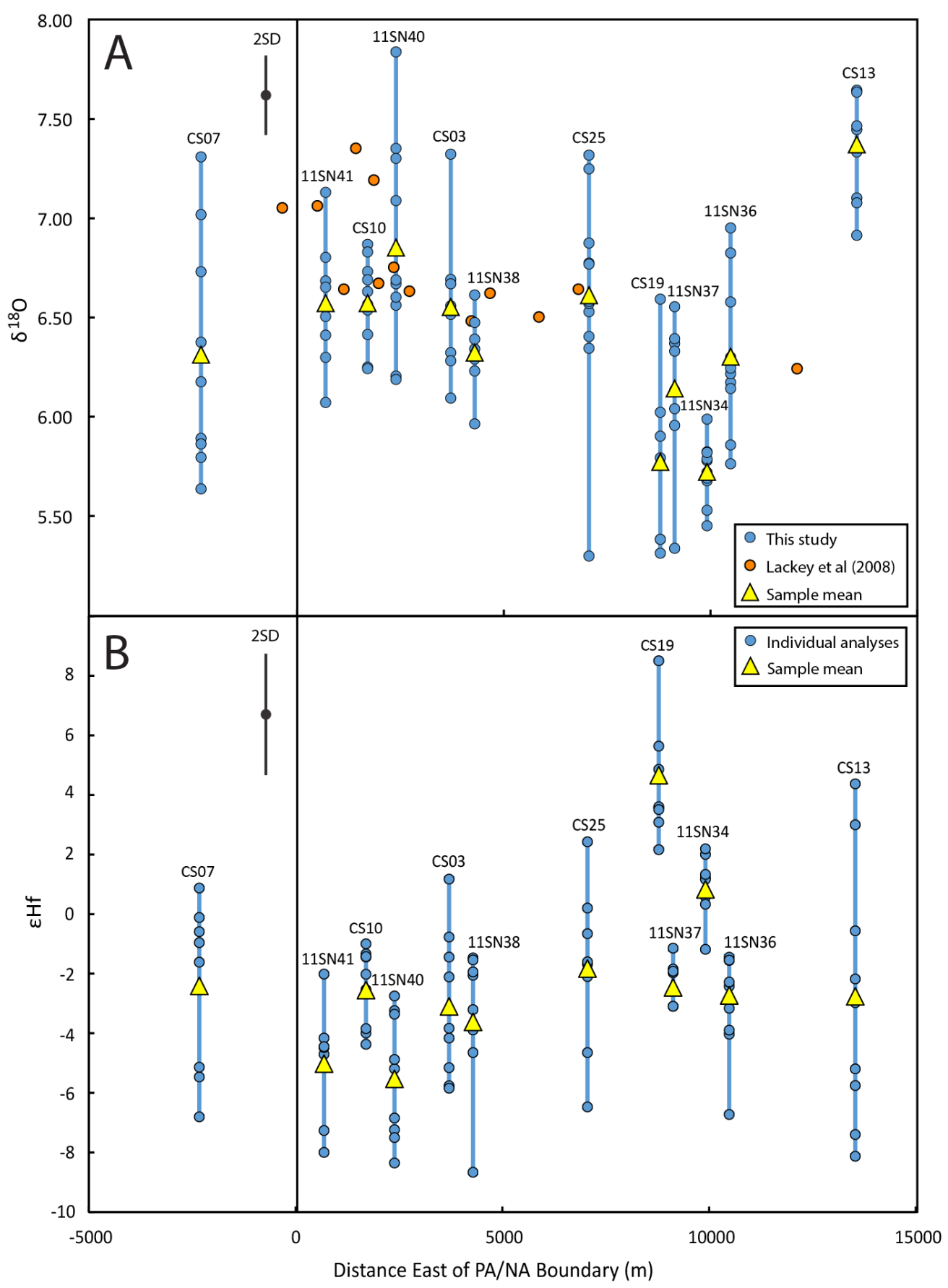

Figure 38. Variation of isotopes along Panthalassan-North American boundary. (a) $\mathrm{O}$ values. (b) Hf values. Bulk laser fluorination $\mathrm{O}$ data are included from Lackey et al. (2008). Blue dots and connecting lines show individual analyses for each sample. Yellow triangles show the sample mean. 


\section{Age Variation}

Isotopic variation is not correlated to age (Fig. 33), indicating that variation cannot be explained simply by changing sources with time. However, the intrusion of the Mount Givens pluton can be broken into two pulses based on zircon isotopic variability. Magmas intruded at or before 95 Ma show a greater range of zircon isotopic variation-compared to those intruded afterwards (Fig. 34). Zircon from samples older

than the granodiorite of Cow Meadow range in $\delta^{18} \mathrm{O}$ from 5.31-7.84\%, while zircon $\delta^{18} \mathrm{O}$ in younger samples does not reach above 6.96\%. Similarly, Hf isotopes in the older group vary by $11 \varepsilon \mathrm{Hf}$ units, while over $90 \%$ of zircon analyses from samples younger than the granodiorite of Cow Meadow are restricted to a $6 \varepsilon \mathrm{Hf}$ range (Fig. 35). Of particular interest in the older group are samples 11SN40 and 11SN34, both in the porphyritic unit of the northern lobe, but on opposite sides of the pluton. Zircons from sample 11SN40 shows wide isotopic variation, reaching to some of the most crustal values, while 11SN34 displays restricted, mantle-like values in both isotopic systems. Samples from the younger age group are isotopically intermediate.

\section{Intercrystalline Variations}

The total within sample isotopic variability is generally larger in older samples (Figure 36). Analyses in these samples also plot as a more continuous spectrum, rather than having an isotopic range defined by a single outlier analysis. The clear exception to this is the porphyritic sample in the northeast corner (11SN34), which shows minimal 


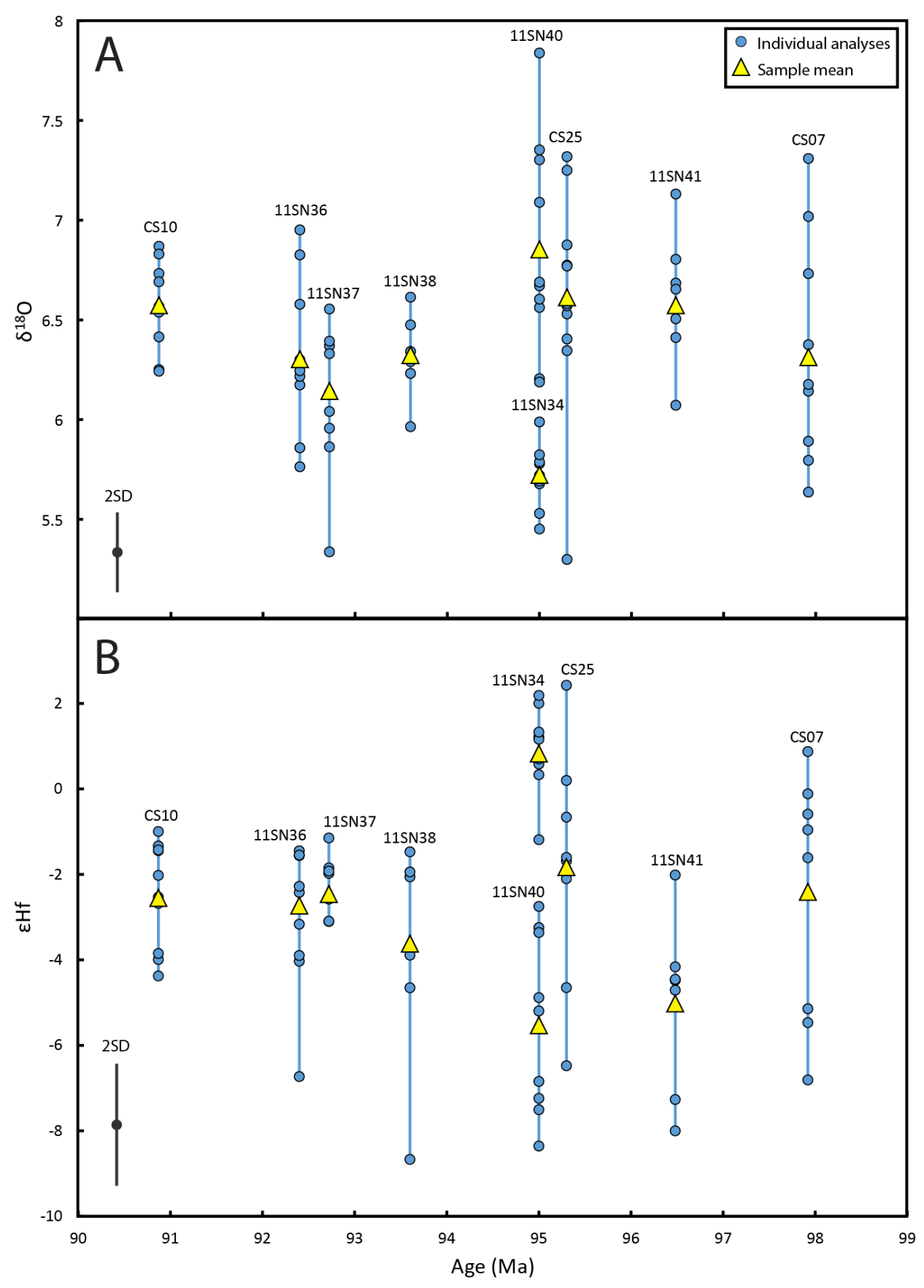

Figure 39. Temporal variation of isotopes. (a) $\delta^{18} \mathrm{O}$ values. (b) Hf values. Blue dots and connecting lines show individual analyses for each sample. Yellow triangles show the sample mean. Plot excludes compositional outliers (CS03, CS13, and CS19). 


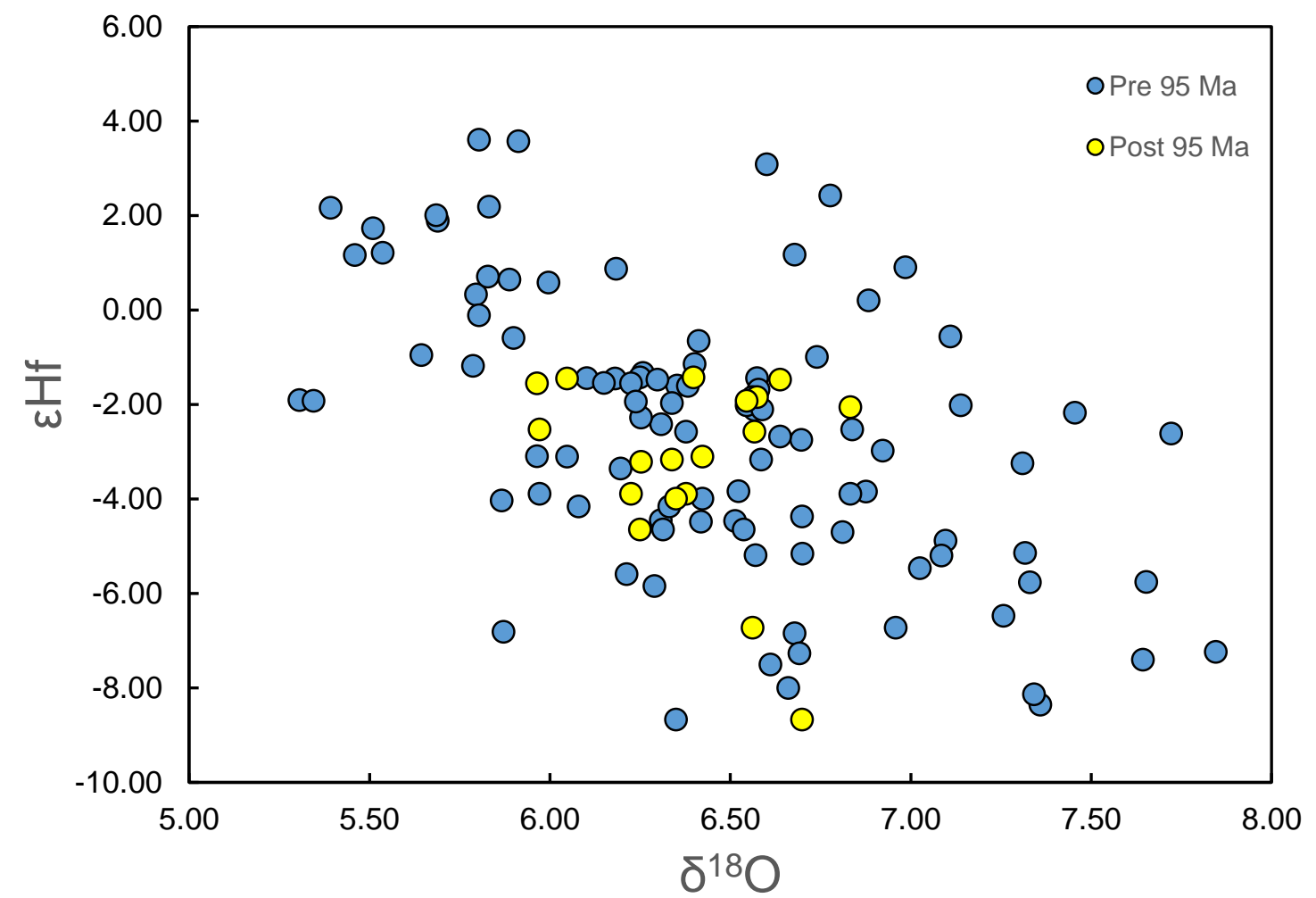

Figure 40. Covariant $\delta^{18} \mathrm{O}$ and $\varepsilon \mathrm{Hf}$ plot showing isotopic differences in pre- and post-95 Ma granodiorites. 


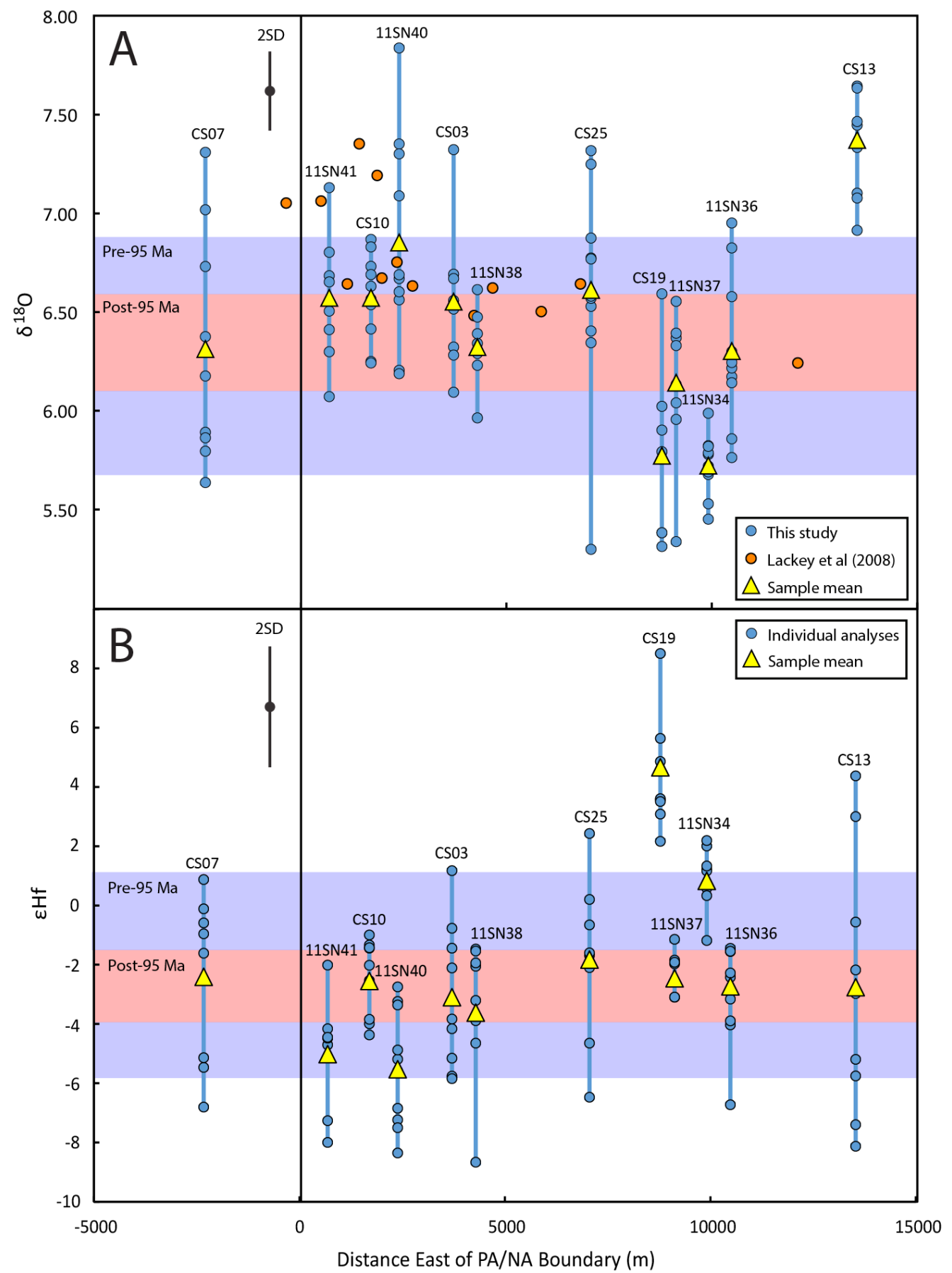

Figure 41. Variation of isotopes across Panthalassan-North American boundary, separated by age. (a) Zircon O values. (b) Zircon Hf values. Bulk laser fluorination O data are included from Lackey et al. (2008). Blue dots and connecting lines show individual analyses for each sample. Yellow triangles show the sample mean. The area shaded in red represents the isotopic range of means in samples younger than $95 \mathrm{Ma}$, and the area shaded in blue represents means in samples older than $95 \mathrm{Ma}$. 
isotopic variability (see Fig. 35). The sample showing the greatest amount of intercrystal dispersion in both isotopes is the oldest porphyritic unit (CS07) (Fig. 35).

Several samples show wide variations in only one of the isotopes, indicating that $\mathrm{O}$ and $\mathrm{Hf}$ isotopic systems were decoupled in certain areas of the pluton. This is particularly evident in the zircon isotopic signatures of the most felsic samples. The aplite of Jackass Rock (11SN37) has consistent $\varepsilon H f$, but a 1.2\%o variation in $\delta^{18} \mathrm{O}$. The

felsic sheet (CS13) has the widest range of $\varepsilon \mathrm{Hf}$, but is restricted to $\delta^{18} \mathrm{O}$ between 6.92 and 7.64\% (Fig. 35).

Several samples have single zircon crystals that are isotopically dissimilar from the rest of the zircon population. This intercrystal variability suggests that mixing of isotopically distinct sources occurred following zircon crystallization in some areas. These crystals sometimes have crustal isotopic signatures, while others have more mantle-like signatures than the main population.

\section{Intracrystalline Variation}

Intracrystalline isotopic variation is also more prevalent in the older samples (Fig. 37A). The most evident variation is in sample 11SN40. Out of five zircon crystals analyzed for $\mathrm{O}$ and $\mathrm{Hf}$, four have a $\delta^{18} \mathrm{O}$ variation of at least $0.75 \%$, and two have $\mathrm{Hf}$ variation of at least $3 \mathrm{\varepsilon Hf}$ units. Zircons in this sample typically have higher $\delta^{18} \mathrm{O}$ cores, although there is one example where this pattern is reversed. Where zircon is significantly zoned, $\varepsilon \mathrm{Hf}$ values become more negative from core to rim. Among other older samples, there does not appear to be significant core to rim trends. 


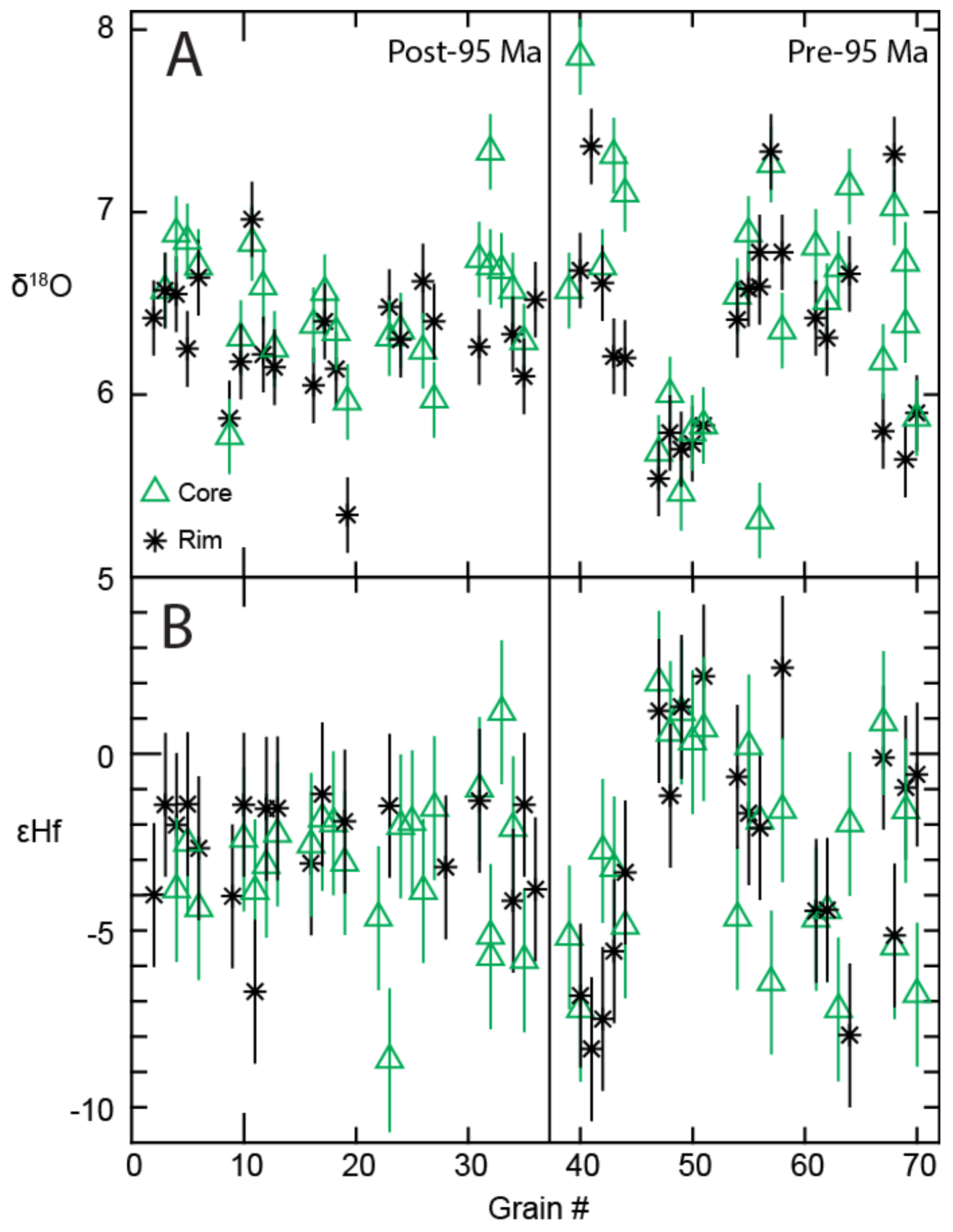

Figure 42. Rank order plot of isotopic variation. (a) $\mathrm{O}$ isotopes. (b) Hf isotopes. In both isotopic systems, inter- and intragrain variation is more prevalent before $95 \mathrm{Ma}$. In the post-95 Ma samples, rims have slightly more juvenile values for both isotopes. This plot does not include samples CS13 and CS19, which do not have sufficient age data. 
Besides a few outlier analyses, younger samples show little intracrystal variability (Fig. 37B). Among these samples, the average value of rims for both isotopes is slightly more primitive than that of cores.

Decoupling of $\mathrm{O}$ and $\mathrm{Hf}$ isotopes in zoned crystals is mostly concentrated in the western portion of the northern lobe (Fig. 37C). In about half of these cases, cores have clearly undergone some resorption, while in others, zoning is uninterrupted and lacks any obvious resorption. Six zircons, each from a different sample, exhibit Hf variation of $\geq 4$ $\varepsilon H f$. In all but one of these crystals, $\delta^{18} \mathrm{O}$ variation is not statistically significant, with one sample in $11 \mathrm{SN} 41$ varying by $\sim 0.5 \%$. These zircons indicate that a decoupling of zircon $\mathrm{O}$ and $\mathrm{Hf}$ systems occurred where large variations in one of the isotopes were introduced without a change in the other.

Four samples have a $\delta^{18} \mathrm{O}$ value that is separated from the sample average by at least two standard deviations. The most dramatic example is a core from CS25 (Fig. 37c) with a value of 5.31\%, 1.2\%o lower than the rim value, and over $1 \%$ lower than the next lowest value in the sample. Among the low $\delta^{18} \mathrm{O}$ zircon crystals, two have cores that show strong textural evidence for resorption. This indicates incorporation of more mantle-like zircons into a higher $\delta^{18} \mathrm{O}$ magma, although this is not correlated with $\mathrm{Hf}$ changes. Both CS03 and CS19 have a single core with a significantly higher $\delta^{18} \mathrm{O}$ than is seen in the rest of the sample. However, the extreme $\mathrm{O}$ values do not correlate with any change in Hf, exemplifying the decoupling described earlier.

Two samples contain one spot with significantly lower Hf values than all other analyses. One analysis is in the core of a zircon from the granodiorite of Cow Meadow, 
and one is on the rim of a zircon in the inner porphyritic unit. Both crystals show no significant $\delta^{18} \mathrm{O}$ variation and lack evidence for resorption.

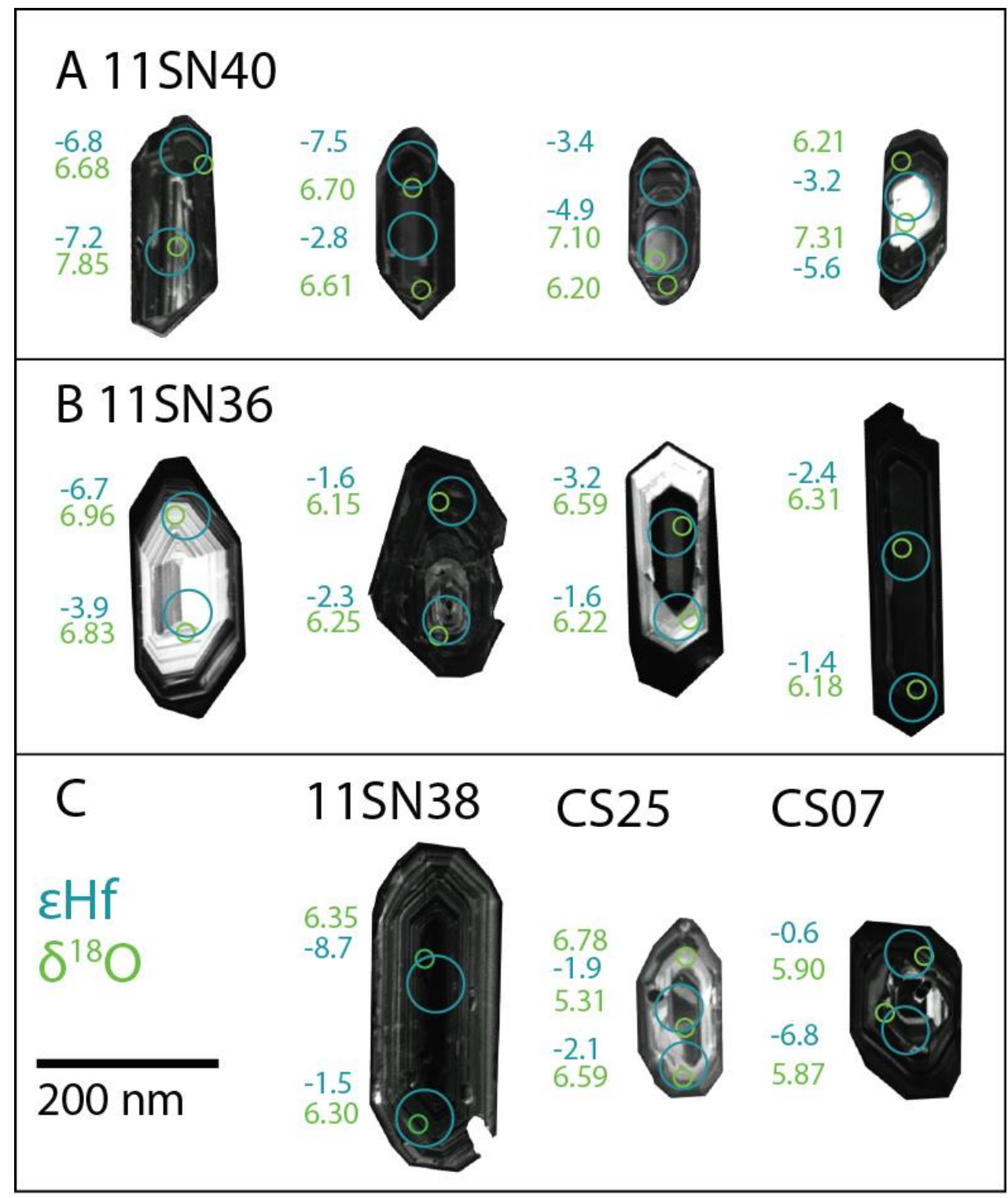

Figure 43. Intracrystalline variation in zircon $\mathrm{O}$ and $\mathrm{Hf}$ isotopes. (a) Zircons from sample 11SN40 shows significant variations in both isotopic systems. (b) Zircons from sample $11 \mathrm{SN} 36$ are representative of the general within-crystal homogeneity of younger samples. (c) Zircons from several samples show a decoupling of isotopic systems on the intracrystalline scale. 


\section{DISCUSSION}

The Mount Givens pluton has been singled out among Sierran plutons as an example of a large $\left(>1000 \mathrm{~km}^{2}\right)$ intrusion that exhibits textural and compositional/mineralogical homogeneity. These characteristics, along with rapid flux rates calculated from bulk zircon dates, lead several researchers to propose that the Mount Givens granodiorite may represent a plutonic equivalent to 'monotonous intermediate' ignimbrites (Bachman et al., 2007; de Silva and Gosnold, 2007; Lipman et al, 2007; Lipman and Bachman, 2015). Recent ID-TIMS data have demonstrated that the Mount Givens pluton was emplaced over approximately 7 million years (Fig. 3), raising questions about the validity of the ignimbrite correlation (Frazer et al., 2014; Coleman et al., 2016). The long timescale of emplacement makes it challenging to explain the overall homogeneity of the Mount Givens pluton. Age variations and thermal considerations preclude both rapid accumulation of compositionally uniform magma and pluton-scale mixing of several major pulses. Thus, it is important to examine the scale of homogeneity within the pluton in more detail, and to assess the zircon crystal record in order to better evaluate the processes that produced this large, homogeneous ('monotonous') intermediate pluton.

Field observations from this study are in agreement with broad compositional and textural trends outlined by earlier work (Bateman and Nokleberg, 1978). However, point counts taken along a northeast-southwest transect show a more limited range of modal mineralogy than previously reported, with nearly all samples plotting within a relatively small area of the granodiorite field of the QAP diagram (Fig. 15). This discrepancy may 
be due to my analysis of a different transect than that of previous workers, and may also indicate more compositional variability in the southern portion of the northern lobe, where previous modal studies (Bateman and Nokleberg, 1978) were performed.

Despite the consistency in modal mineralogy throughout much of the pluton, field observations from this study document the involvement of multiple magmatic phases. Observations from the east-central portion of the pluton in areas previously mapped as equigranular granodiorite with a high abundance of subangular mafic inclusions (Bateman et al., 1971) demonstrate that $\mathrm{m}$ - to km-scale mixing and hybridization occurred between the host Mount Givens granodiorite, felsic sheets, and mafic bodies in this area (Fig. 12). Unfortunately, no age data are available to more clearly constrain the timing of these compositional outliers with respect to the main granodioritic mass, but the field relationships suggest that the coarse-grained Mount Givens granodiorite host was clearly still mobile, or susceptible to appreciable remobilization, when the felsic sheets and mafic bodies were constructed. The mafic enclave swarms and mafic bodies documented here, and in other work (Tobisch et al., 1997) demonstrate that mafic magmas were important throughout most of pluton growth.

Although field observations in the Mount Givens pluton provide evidence of interaction between multiple batches of compositionally distinct magmas, the finer-scale information recorded in zircon provides a more detailed record of magmatic processes occurring at the onset of crystallization. All analyzed zircons from the Mount Givens suite have high Ti-in-zircon temperatures (Fig. 19) that are consistently higher than zircon saturation temperatures. This indicates that magmas were initially undersaturated 
in zircon at anatectic temperatures (cf. Harrison et al., 2007), which would dissolve zircon inherited from melt sources. Therefore, trace element and $\mathrm{Hf}$ and $\mathrm{O}$ isotopic signatures of zircons reflect those of the magmas from which zircon crystallized after the magmas had cooled sufficiently to saturate in zircon, probably during ascent and/or after emplacement.

The zircon trace element and isotopic data presented in this study, in combination with CA-ID-TIMS dates from Frazer et al. (2014), document changes in the Mount Givens magmatic system over time. Zircon trace element signatures show broad trends that are consistent with down-temperature fractionation for all units; however, the degree of scatter in these data suggest that more complex magmatic processes occurred during zircon crystallization (Figs. 25-29). All samples contain zircons showing normal downtemperature trace element trends. However, because nearly all samples also contain zircon crystals that are reversely zoned in $\mathrm{Hf}, \mathrm{Ti}, \mathrm{Yb} / \mathrm{Gd}$, and $\mathrm{Th} / \mathrm{U}$, transfer of zircon crystals between 'hot'/more juvenile and 'cold'/more evolved magmas was common throughout pluton growth (Figs. 30-35). The continual interaction of thermally and geochemically distinct magmas documented here is consistent with a mush system where some zircons are incorporated as antecrysts in hotter magmas midway through their growth. Instances where changes in individual trace element values and ratios are inconsistent with general normal or reverse zonation within the crystal (e.g. decoupling of $\mathrm{Hf}$ and $\mathrm{Ti}$ ) may be due to crystallization of minerals that drastically affected local trace element budgets, particularly titanite, which is ubiquitous in the Mount Givens granodiorite. The only clearly distinguishable variation in trace elements with age is the 
higher Eu/Eu* values in post-95 Ma samples (Fig. 34), which may indicate early plagioclase fractionation, a transition to a more plagioclase rich source (Hoskin and Schaltegger, 2003), or a systematic change in magmatic oxygen fugacity conditions (Trail et al., 2012).

Isotope analysis of zircon from samples older than $95 \mathrm{Ma}$, indicates that the isotopic compositions and the degree of mixing of isotopically disparate magmas varied across the pluton during zircon crystallization. Samples 11SN40 and 11SN34, two porphyritic samples of the same age located in the western and eastern portions of the northern lobe respectively (Fig. 5), demonstrate this contrast. The complete lack of overlap between the zircon isotopic compositions of these two samples indicates a lack of unit-wide mixing of magmas. The presence of intracrystal variation in several of the older samples, most notably 11SN40 (Fig. 37), indicates that crystals were transferred between isotopically distinct magmas during the span of their growth. In contrast, the minimal variation in isotopes ratios in sample 11SN34 may indicate that magma feeding the eastern portion of the intrusion was more isotopically homogeneous, or that this portion of the pluton cooled quickly enough that later pulses did not mix appreciably. Finer-scale sampling may resolve if these hypotheses are correct.

Beginning with the intrusion of the granodiorite of Cow Meadow, the isotopic composition of zircon became significantly more homogeneous. This homogeneity is visible at all scales, as the variation between and within samples as well as within individual crystals decreases. Zircon isotopic compositions for these samples largely fall in the middle of the measured range of older samples (Fig. 34). Given that magmas were 
not likely saturated at the source, this observation suggests that the decrease in variability is related to mid-crustal level homogenization of magma bodies that produced the Mount Givens pluton. The decrease in inter- and intracrystalline isotopic variation indicates an overall more connected, and thermally mature system that was well mixed at the hand sample scale and remained so throughout zircon growth.

The negative covariation observed for zircon $\mathrm{Hf}$ and $\mathrm{O}$ data for the Mount Givens sample suite (Fig. 30) is also consistent with mixing and reflects contributions from several isotopically distinct magma sources. Four commonly cited sources for the granitoids of the Sierra Nevada batholith include: depleted mantle, enriched mantle, Proterozoic crust, and Panthalassan crust (Kistler, 1990; Beard and Glazner, 1995; Coleman et al., 1997; Lackey et al., 2008).

Figure 38 shows a mixing model for zircon $\mathrm{Hf}$ and $\mathrm{O}$ isotope measurements of Mount Givens samples using these end members. The isotopic composition of the mantle end members is based primarily on measurements of Cenozoic basalts in the Sierra Nevada batholith (Beard and Johnson, 1997; Nelson et al., 2013). The depleted and enriched mantle reservoirs differ by up to $15 \mathrm{\varepsilon Hf}$. Isotopic compositions for the two crustal reservoirs, Proterozoic and Panthalassan, are based on values from Lackey et al. (2012). Due to its derivation from oceanic sediments, the Panthalassan crust has significantly more radiogenically derived Hf than the Proterozoic crust (Lackey et al., 2012). 


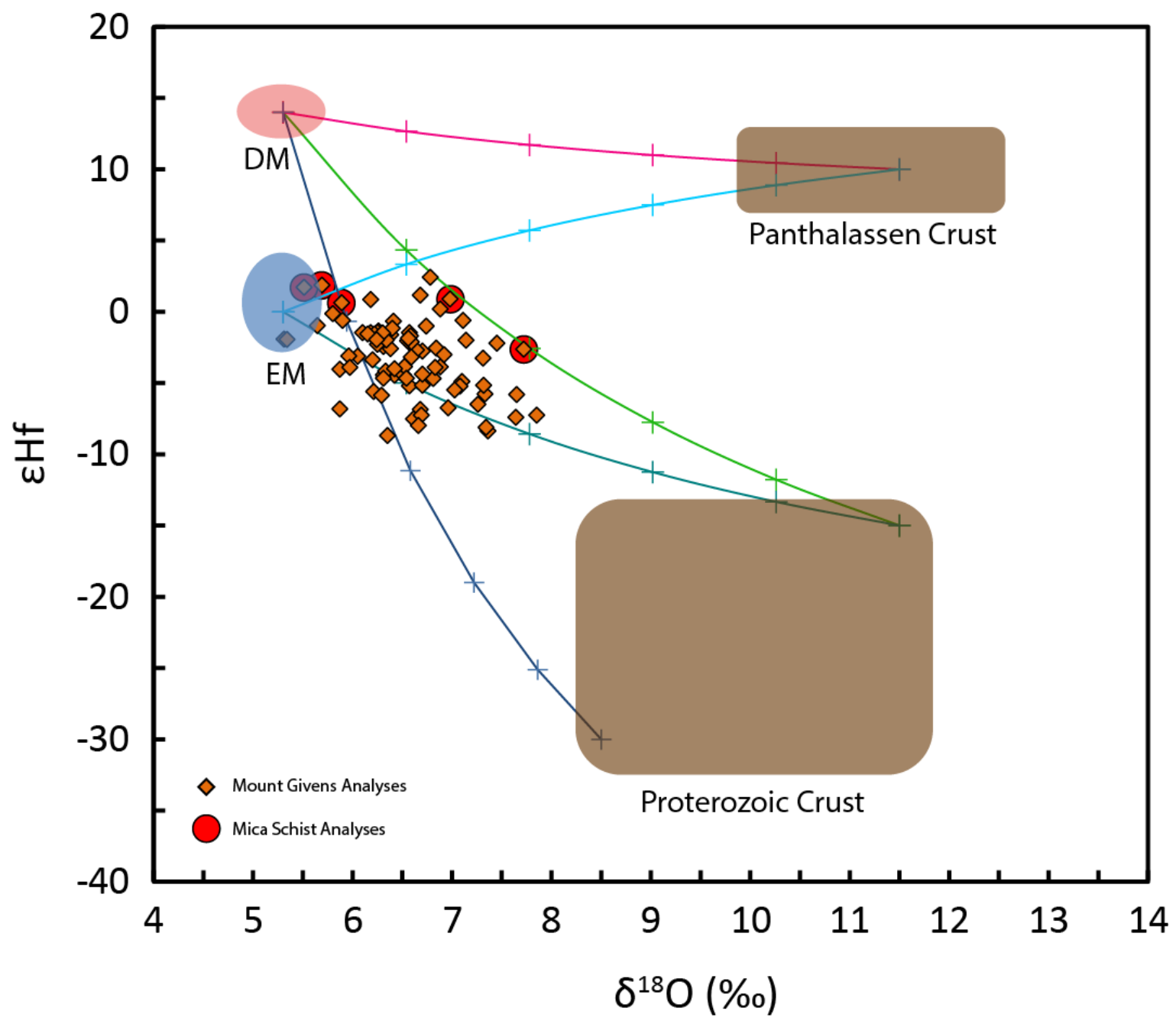

Figure 44. Mixing model for zircon isotopic compositions of Mount Givens samples. Orange diamonds show zircon isotopic compositions of samples from the Mount Givens pluton. Red circles plot zircon isotopic compositions of the mica schist sampled in this study. Colored lines are isotopic mixing curves between the different reservoirs.

Isotopic mixing models involving radiogenic isotopes can be sensitive to elemental concentrations of the isotopes, but $\mathrm{O}$ is assumed to be readily available in all silicate reservoirs, and thus mixing is a simple binary linear relationship and a function only of proportion of the end members. The concentration of Hf in the probable end 
members is variable, which makes this the largest source of uncertainty in the mixing model shown in Figure 38. Crustal Hf concentrations, both Proterozoic and Panthalassan, for the model were estimated from the global average of Taylor and McLennan (1995). Compositions of Cenozoic basalts in the western U.S. provide a wide range of possible Hf concentrations for both the depleted (2-8 ppm) and enriched (4-9 ppm) mantle (Beard and Johnson, 1997; Nelson et al., 2013). The model displayed here uses a low value of $3 \mathrm{ppm}$ for the $\mathrm{Hf}$ concentration of the depleted mantle; increasing this number produces an increasingly poor fit. For a complete explanation of mixing curve parameters see Appendix F.

The spread of data makes it difficult to uniquely identify the melt sources, but the mixing model can be used to outline some general constraints. The decrease of zircon $\varepsilon \mathrm{Hf}$ with increasing zircon $\delta^{18} \mathrm{O}$ requires the involvement of nonradiogenic, probably Proterozoic, crust, which is consistent with other isotopic studies of Sierran plutons (DePaolo, 1987; Kistler, 1990; Lackey et al., 2008; 2012). The high $\varepsilon H f$ of the mica schist, plotted as red circles in Figure 38, indicates its potential affinity with Panthalassan lithosphere. The observation that it bounds the high $\varepsilon \mathrm{Hf}$ end of the Mount Givens granodiorite samples also makes it a possible contributor to some of the observed isotopic variation of zircon in the pluton. Several spots with mantle-like $\delta^{18} \mathrm{O}$ fall in the range of enriched mantle $\varepsilon H f$. However, $\varepsilon \mathrm{Hf}$ analyses of zircons from the mafic body in the central portion of the pluton (CS19) reach $\varepsilon H f$ values of up to +9 (Fig. 32), indicating contributions from the depleted mantle as well. These data points are not plotted on Figure 31 because they do not have associated $\delta^{18} \mathrm{O}$ values. 
Evidence for isotopic mixing between depleted mantle and Proterozoic crust has been suggested for several granitic suites in the Sierra Nevada batholith based on O, Hf, Sr, and Nd isotopic signatures (DePaolo, 1981; Lackey et al., 2012; Nelson et al., 2013). The incorporation of Proterozoic crust, and possibly the depleted mantle, in the formation of Mount Givens magmas distinguishes it from large intrusive suites to the east that have been suggested to have formed almost exclusively by melting and refinement of enriched mantle sources (Coleman et al., 1992; Coleman and Glazner, 1997; Wenner and Coleman, 2004).

The fact that zircon isotopic composition correlates to longitude, and not age, indicates that melts were tapping different sources based on geographic location. This is particularly evident in the older samples, which span a much wider range of $\delta^{18} \mathrm{O}$ and $\varepsilon H f$. The negligible intracrystalline variation, low $\delta^{18} \mathrm{O}$, and high $\varepsilon \mathrm{Hf}$ in the easternmost sample of the northern lobe suggest a homogeneous melt with a significant mantle contribution. In contrast, samples in the western portion of the northern lobe show significant variation within individual crystals, higher $\delta^{18} \mathrm{O}$, and lower $\varepsilon H f$ indicating a melt that has a significant crustal component. Scatter and intracrystalline variation in trace element values and ratios also suggest transfer of zircon crystals between geochemically variable melts, although this scatter is present in younger samples as well. The abrupt transition to more homogenous zircon isotopic compositions, intermediate to those seen in early magmatism, beginning with the intrusion of the granodiorite of Cow Meadow, suggests a significant change in the Mount Givens magmatism at this time. 
Based on the lack of overlap in zircon ages between units older than and younger than the granodiorite of Cow Meadow (Fig. 3), Frazer et al. (2014) concluded that the outer and inner portions of the northern lobe had little interaction. This suggestion is consistent with the sharp intrusive contact of the Cow Meadow granodiorite and the zircon isotopic data presented here, which suggest a significant difference in isotopic variability between the inner and outer magmas. This late isotopic homogeneity is also reflected in the single granodioritic sample from the southern lobe. The shorter timeframe of intrusion (Frazer et al., 2014), and narrow range of isotopic variability are consistent with a thermally mature and more isotopically homogeneous source, such as a magma assimilation, storage, and homogenization (MASH) zone, and increased intrusive flux into the arc. Appreciable trace element variability suggests efficient mixing and crystal transfer following the onset of zircon crystallization. The considerable overlap in zircon ages of post-95 Ma samples, along with their isotopically homogeneous character, suggest that they record continuous zircon crystallization, within a contiguous magma body of considerable size (10's to 100 's of $\mathrm{km}^{3}$ ) that was present in the late stages of Mount Givens magmatism.

\section{CONCLUSIONS}

1. Field observations and point count data from this study are consistent with the mapping and petrologic patterns recorded by previous researchers. A more detailed description of a mixing zone in the east central portion of the pluton documents interactions between at least four generations of magma in an area several $\mathrm{km}$ wide. 
2. Consistently high Ti-in-zircon temperatures for all zircons suggest that all magmas were produced by melting at high-temperatures under conditions of water undersaturation (e.g. amphibole dehydration). Initial melts were undersaturated in zircon, and zircon growth occurred during magma ascent and/or emplacement.

3. Variation in zircon isotopic composition indicates mixing of magmas that are derived from several distinct isotopic sources. Longitudinal variation in $\delta^{18} \mathrm{O}$ and $\varepsilon \mathrm{Hf}$ suggests increasing mantle contributions in the eastern portion of the pluton.

4. Trace element signatures indicate that normal down-temperature fractionation of magmas was common during zircon crystallization. However, all samples show evidence of reverse zonation in trace elements, indicating that crystal transfer between thermally and chemically distinct environments was also occurring.

5. The characteristics of pre-95 Ma magmatism appear to be spatially controlled, with more homogeneous mantle-like magmas to the east and more heterogeneous magmas to the west that contain a greater crustal contribution.

6. Post-95 Ma magmas were likely derived from the same sources, but magmas were more thoroughly mixed in a mature MASH zone and/or in larger intrusive pulses. The narrow timespan and homogeneity of the zircon isotopic population suggest that the inner portion of the northern lobe may have existed as a large melt or crystal mush reservoir. 


\section{REFERENCES}

Ague, J.J., and Brimhall, G.H., 1988, Magmatic arc asymmetry and distribution of anomalous plutonic belts in the batholiths of California: Effects of assimilation, crustal thickness, and depth of crystallization: Geological Society of America Bulletin, v. 100, p. 912-927.

Bachman, O., Miller, C.F., and de Silva, S.L., 2007, The volcanic-plutonic connection as a stage for understanding crustal magmatism: Journal of Volcanology and Geothermal Research, v. 167, p. 1-23.

Barth, A.P., Tosdal, R.M., Wooden, J.L., and Howard, K.A., 1988, San Jacinto intrusive complex; 1, Geology and mineral chemistry, and a model for intermittent recharge of tonalitic magma chambers: Journal of Geophysical Research, v. 93, no. B9, p. 10,325-10,348.

Barth, A.P., and Wooden, J.L., 2010, Coupled elemental and isotopic analyses of polygenetic zircons from granitic rocks by ion microprobe, with implications for melt evolution and the sources of granitic magmas: Chemical Geology, v. 277, p. 149-159.

Bateman, P.C., Lockwood, J.P., and Lydon, P.A., 1971, Geologic map of the Kaiser Peak Quadrangle, Central Sierra Nevada, California: U.S. Geological Survey, Report: GQ-0894, scale 1:62500.

Bateman, P.C., 1974, Model for the origin of Sierran granites: California Geology, v. 27, p. $1-5$.

Bateman, P.C., and Chappell, B.W., 1979, Crystallization, fractionation, and solidification of the Tuolumne Intrusive Series, Yosemite National Park, California: Geological Society of America Bulletin, v. 90, p. 465-482.

Bateman, P.C., and Nokleberg, W.J., 1978, Solidification of the Mount Givens Granodiorite, Sierra Nevada, California: Journal of Geology, v. 86, p. 563-579.

Bateman, P.C., 1992, Plutonism in the central part of the Sierra Nevada Batholith, California: U.S.Geological Survey Professional Paper, 2 sheets, 186 p.

Belousova, E.A., Griffin, W.L., O'Reilly, S.Y., and Fisher, N.I., 2002, Igneous zircon; trace element composition as an indicator of source rock type: Contrib to Mineral and Petrol, v. 143, p. 602-622.

Bindeman, I., Putirka, K.D., and Tepley, F.J.,III, 2008, Oxygen isotopes in mantle and crustal magmas as revealed by single crystal analysis: Reviews in Mineralogy and Geochemistry, v. 69, p. 445-478. 
Bliekendaal, E., 2012, Formation of the Yosemite Creek Granodiorite: A field and geochemical study [M.S. thesis]: Vrije University, Amsterdam, 155p.

Boehnke, P., Watson, E.B., Trail, D., Harrison, T.M., and Schmitt, A.K., 2013, Zircon saturation re-revisited: Chemical Geology, v. 351, p. 324-334.

Brown, E.H., and McClelland, W.C., 2000, Pluton emplacement by sheeting and vertical ballooning in part of the southeast Coast Plutonic Complex, British Columbia: Geological Society of America Bulletin, v. 112, p. 708-719.

Buddington, A.F., 1959, Granite emplacement with special reference to North America: Geological Society of America Bulletin, v. 70, p. 671-748.

Burgess, S.D., and Miller, J.S., 2008, Construction, solidification and internal differentiation of a large felsic arc pluton: Cathedral Peak granodiorite, Sierra Nevada Batholith: Geological Society of London, Special Publications, v. 304, p. 203-233, doi: 10.1144/SP304.11.

Cavosie, A.J., Valley, J.W., and Wilde, S.A., 2006, Correlated microanalysis of zircon; trace element, $\delta^{18} \mathrm{O}$ and $\mathrm{U} / \mathrm{Th} / \mathrm{Pb}$ isotopic constraints on the igneous origin of complex > 3900 Ma detrital grains: Geochimica Et Cosmochimica Acta, v. 70, p. 5601-5616.

Cherniak, D.J., Hanchar, J.M., and Watson, E.B., 1995, Hf and rare earth diffusion in zircon: EOS, Transactions, American Geophysical Union, v. 76, p. 704.

Chu, N., Taylor, R.N., Valérie, C., Nesbitt, R.W., Boella, R.M., Milton, A., German, C.R., Bayon, G., and Burton, K., 2002, Hf isotope ratio analysis using multicollector inductively coupled plasma mass spectrometry: an evaluation of isobaric interference corrections: Journal of Analytical Atomic Spectrometry, v. 17, p. 1567-1574, doi: 10.1039/b206707b.

Claiborne, L.L., Miller, C.F., Walker, B.A., Wooden, J.L., Mazdab, F.K., and Bea, F., 2006, Tracking magmatic processes through $\mathrm{Zr} / \mathrm{Hf}$ ratios in rocks and $\mathrm{Hf}$ and $\mathrm{Ti}$ zoning in zircons; an example from the Spirit Mountain Batholith, Nevada: Mineralogical Magazine, v. 70, p. 517-543.

Claiborne, L.L., Miller, C.F., and Wooden, J.L., 2010, Trace element composition of igneous zircon: a thermal and compositional record of the accumulation and evolution of a large silicic batholith, Spirit Mountain, Nevada: Contributions to Mineralogy and Petrology, v. 160, p. 511-531, doi: 10.1007/s00410-010-0491-5.

Coleman, D.S., and Glazner, A.F., 1997, The Sierra Crest magmatic event; rapid formation of juvenile crust during the Late Cretaceous in California: International Geology Review, v. 39, p. 768-787. 
Coleman, D.S., Gray, W., and Glazner, A.F., 2004, Rethinking the emplacement and evolution of zoned plutons; geochronologic evidence for incremental assembly of the Tuolumne intrusive suite, California: Geology, v. 32, p. 433-436.

Davis, J.W., Coleman, D.S., Gracely, J.T., Gaschnig, R., and Stearns, M., 2012, Magma accumulation rates and thermal histories of plutons of the Sierra Nevada batholith, CA: Contributions to Mineralogy and Petrology, v. 163, p. 449-465.

de Silva, S.L., and Gosnold, W.D., 2007, Episodic construction of batholiths: Insights from the spatiotemporal development of an ignimbrite flare-up: Journal of Volcanology and Geothermal Research, v. 167, p. 320-335.

DeCelles, P.G., Ducea, M.N., Kapp, P., and Zandt, G., 2009, Cyclicity in Cordilleran orogenic systems: Nature Geoscience, v. 2, p. 251-257, doi: 10.1038/ngeo469.

Ducea, M., 2001, The California arc: Thick Granitic Batholiths, Eclogitic Residues, Lithospheric-Scale Thrusting, and Magmatic Flare-Ups: GSA Today, v. 11, no. 11, p. 4-10.

Ferriss, E.D.A., Essene, E.J., and Becker, U., 2008, Computational study of the effect of pressure on the Ti-in-zircon thermometer: European Journal of Mineralogy, v. 20, p. 745-755, doi: 10.1127/0935-1221/2008/0020-1860.

Ferry, J.M., and Watson, E.B., 2007, New thermodynamic models and revised calibrations for the Ti-in-zircon and Zr-in-rutile thermometers: Contributions to Mineralogy and Petrology, v. 154, p. 429-437.

Fisher, C.M., Vervoort, J.D., and DuFrane, S.A., 2014, Accurate Hf isotope determinations of complex zircons using the "laser ablation split stream method": Gechemistry, Geophysics, Geosystems, v. 15, p. ?, doi: 10.1002/2013GC004962.

Frazer, R.E., Coleman, D.S., and Mills, R.D., 2014, Zircon U-Pb geochronology of the Mount Givens Granodiorite: implications for the genesis of large volumes of eruptible magma, Journal of Geophysical Research: Solid Earth, v. 119, p. 1-18.

Fulmer, E., and Kruijer, T., 2009. The nature of batholith formation: detailed field, geochemical and isotopic constraints on the assembly of the Sentinel Granodiorite, Sierra Nevada Batholith, USA [M.S. thesis]: Vrije University, Amsterdam, $272 \mathrm{p}$.

Gilder, S., and McNulty, B.A., 1999, Tectonic exhumation and tilting of the Mount Givens pluton, central Sierra Nevada, California: Geology, v. 27, p. 919-922, doi: 10.1130/0091-7613. 
Glazner, A.F., Bartley, J.M., Coleman, D.S., Gray, W., and Taylor, R.Z., 2008, Are plutons assembled over millions of years by amalgamation from small magma chambers?: GSA Today, v. 14, no. 4, p. 4-11, doi: 10.1130/1052-5173.

Hamilton, W., 1969, Mesozoic California and the underflow of Pacific mantle: Geological Society of America Bulletin, v. 80, p. 2409-2430.

Harrison, T.M., Watson, E.B., and Aikman, A.B., 2007, Temperature spectra of zircon crystallization in plutonic rocks: Geology, v. 35, p. 635-638, doi: 10.1130/G23505A.1.

Hawkesworth, C.J., and Kemp, A.I.S., 2006, Using hafnium and oxygen isotopes in zircons to unravel the record of crustal evolution: Chemical Geology, v. 226, p. 144-162.

Hayden, L.A., and Watson. E.B., 2007, Rutile saturation in hydrous silicate melts and its bearing on Ti-thermometry of quartz and zircon: Earth and Planetary Science Letters, v. 258, p. 561-568.

Hill, M., O’Neil, J.R., Noyes, H., Frey, F.A., and Wones, D.R., 1988, Sr, Nd, and O isotope variations in compositionally zoned and unzoned plutons in the Central Sierra Nevada Batholith: American Journal of Science, v. 288-A, p. 213-241.

Hirt, W.H., 2007, Petrology of the Mount Whitney intrusive suite, eastern Sierra Nevada, California: Implications for the emplacement and differentiation of composite felsic intrusions: GSA Bulletin, v. 199, p. 1185-1200.

Kemp, A., Hawkesworth, C.J., Paterson, B., and Kinny, P.D., 2006, Episodic growth of the Gondwana supercontinent from hafnium and oxygen isotopes in zircon: Nature, v. 439, p. 580-583.

Kinny, P.D., and Maas, R., 2003, Lu-Hf and Sm-Nd isotope systems in zircon: Reviews in Mineralogy and Geochemistry, v. 53, p. 327-341.

Kistler, R.W., 1990, Two different lithosphere types in the Sierra Nevada, California: Geological Society of America Memoir, v. 174, p. 271-281.

Kistler, R.W., and Peterman, Z.E., 1973, Variations in Sr, Rb, K, and Na, and initial $\mathrm{Sr}_{87} / \mathrm{Sr}_{86}$ in Mesozoic granitic rocks and intruded wall rocks in Central California: Geological Society of America Bulletin, v. 84, p. 3489-3512.

Kita, N.T., Bin Fu, T.U., and Valley, J.W., 2009, High precision SIMS oxygen isotope analysis and the effect of sample topography: Chemical Geology, v. 264, p. 4357, doi: 10.1016/j.chemgeo.2009.02.012. 
Lackey, J.S., Cecil, M.R., Windham, C.J., Frazer, R.E., Bindeman, I.N., and Gehrels, G.E., 2012, The Fine Gold Intrusive Suite: The roles of basement terranes and magma source development in the Early Cretaceous Sierra Nevada batholith: Geosphere, v. 8, p. 292-313, doi: 10.113/GES00745.1.

Lackey, J.S., Valley, J.W., Chen, J.H., and Stockli, D.F., 2008, Dynamic magma systems, crustal recycling and alteration in the Central Sierra Nevada Batholith; the oxygen isotope record: Journal of Petrology, v. 49, p. 1397-1426.

Lipman, P.W., 2007, Incremental assembly and prolonged consolidation of Cordilleran magma chambers: Evidence from the Southern Rocky Mountain volcanic field: Geoshpere, v. 3, p. 42-70.

Ludwig, K., 2009, SQUID2: A software that for reducing raw- files produced by SHRIMP instruments: Berkley Geochronology Center, http://www.bgc.org/isoplot_etc/squid.html.

Macias, S., 1996, The Sonora Intrusive Suite: Constraints on the assembly of a Late Cretaceous, concentrically-zoned granitic pluton of the Sierra Nevada batholith [M.S. Thesis]: Seattle, University of Washington, 68p.

Mattinson, J., 2005 Zircon U-Pb cemical abrasion (“CA-TIMS”) method: combined annealing and multi-step partial dissolution analysis for improved precision and accuracy of zircon ages: Chemical Geology, v. 220, p. 47-66.

Matzel, J.E.P., Bowring, S.A., and Miller, R.B., 2006, Time scales of pluton construction at differing crustal levels; examples from the Mount Stuart and Tenpeak Intrusions, north Cascades, Washington: Geological Society of America Bulletin, v. 118, p. 1412-1430.

McNulty, B.A., Tobisch, O.T., Cruden, A.R., and Gilder, S., 2000, Multistage emplacement of the Mount Givens Pluton, central Sierra Nevada Batholith, California: Geological Society of America Bulletin, v. 112, p. 119-135.

Memeti, V., Paterson, S., Matzel, J., Mundil, R., and Okaya, D., 2010, Magmatic lobes as "snapshots" of magma chamber growth and evolution in large, composite batholiths: An example from the Tuolumne intrusion, Sierra Nevada, California: Geological Society of America Bulletin, v. 122, p. 1912-1931.

Miller, C.F., McDowell, S.M., Wapes, R.W., 2003, Hot and cold granites? Implications of zircon saturation temperatures and preservation of inheritance: Geology, v. 31, p. 529-532. 
Miller, J.S., Matzel, J.E.P., Miller, C.F., Burgess, S.D., and Miller, R.B., 2007, Zircon growth and recycling during the assembly of large, composite arc plutons: Journal of Volcanology and Geothermal Research, v. 167, p. 282-299.

Miller, J.S., Miller, R.B., and Stock, G., 2014, Sentinel Granodiorite, Yosemite Creek Granodiorite, and Yosemite Valley Intrusive Suite: Western host units of the Tuolumne Intrusive Complex, in Formation of the Sierra Nevada Batholith: Magmatic and Teconic Processes and Their Tempos: Geological Society of America Field Guides, v. 34, p. 33-41.

Miller, R.B., and Paterson, S.R., 2001, Construction of mid-crustal sheeted plutons: Examples from the North Cascades, Washington: Geological Society of America Bulletin, v. 113, p. 1423-1442, doi: 10.1130/00167606(2011)113<1423:COMCSP>2.0.CO;2.

Morel, M.L.A., Nebel, O., Nebel-Jacobsen, Y.J., Miller, J.S., and Vroon, P.Z., 2008, Hafnium isotope characterization of the GJ-1 zircon reference material by solution and laser ablation MC-ICPMS: Chemical Geology, v. 255, p. 231-235, doi: 10.1016/j.chemgeo.2008.06.040.

Nelson, W.R., Dorais, M.J., Christiansen, E.H., and Hart, G.L., 2013, Petrogenesis of Sierra Nevada plutons inferred from the $\mathrm{Sr}, \mathrm{Nd}$, and $\mathrm{O}$ isotopic signatures of mafic igneous complexes in Yosemite Valley, California: Contributions to Mineralogy and Petrology, v. 165, p. 397-417, doi: 10.1007/s00410-012-0814-9.

Omerod, D.S., Rogers, N.W., and Hawkesworth, C.J., 1991, Melting in the lithospheric mantle: Inverse modelling of alkali-olivine basalts from the Big Pine Volcanic Field, California: Contributions to Mineralogy and Petrology, v. 108, p. 305-317.

Page, F.Z., Ushikubo, T., Kita, N.T., Riciputi, L.R., and Valley, J.W., 2007, Highprecision oxygen isotope analysis of picogram samples reveals $2 \mu \mathrm{m}$ gradients and slow diffusion in zircon: American Mineralogist, v. 92, p. 1772-1775.

Paterson, S.R., Fowler, T.K., and Miller, R.B., 1996, Pluton emplacement in arcs: a crustal-scale exchange process: Transactions of the Royal Society of Edinburgh, Earth Sciences, v. 87, p. 115-123.

Paterson, S.R., Okaya, D., Memeti, V., Economos, R., and Miller, R.B., 2011, Magma addition and flux calculations of incrementally constructed magma chambers in continental margin arcs: combined field, geochronologic, and thermal modeling studies: Geosphere, v. 7, p. 1-30.

Petford, N., Cruden, A.R., McCaffrey, K., and Vigneresse, J., 2000, Granite magma formation, transport and emplacement in the Earth's crust: Nature, v. 408, p. 669673. 
Reid Jr., J.B., and Hamilton, M.A., 1987, Origin of Sierra Nevadan granite: evidence from small scale composite dikes: Contributions to Mineralogy and Petrology, v. 96, p. 441-454.

Sawka, W.N., 1988, REE and trace element variations in accessory minerals and hornblende from the strongly zoned McMurry Meadows pluton, California: Transactions of the Royal Society of Edinburgh, Earth Science, v. 29, p. 157-168.

Sharp, Z., 2007, Principles of Stable Isotope Geochemistry: New York, Prentice Hall, $360 \mathrm{p}$.

Sláma, J., Košler, J., Condon, D.J., Crowley, J.L., Gerdes, A., Hanchar, J.M., Horstwood, M.S.A., Morris, G.A., Nasdala, L., Norberg, N., Schaltegger, U., Schoene, B., Tubrett, M.N., and Whitehouse, M.J., 2008, Plešovice zircon - A new natural reference material for $\mathrm{U}-\mathrm{Pb}$ and $\mathrm{Hf}$ isotopic microanalysis: Chemical Geology, v. 249, p. 1-35, doi: 10.1016/j.chemgeo.2007.11.005.

Stern, T.W., Bateman, P.C., Morgan, B.A., Newell, M.F., and Peck, D.L., 1981, Isotopic $\mathrm{U}-\mathrm{Pb}$ ages of zircon from the granitoids of the central Sierra Nevada, California: U.S. Geological Survey Professional Paper.

Stern, R.A., and Amelin, Y., Assessment of errors in SIMS zircon U-Pb geochronology using a natural zircon standard and NIST SRM 610 glass: Chemical Geology, v. 197, p. 111-142.

Streckeisen, A., 1976, To each plutonic rock its proper name: Earth-Science Reviews, v. 12, p. 1-33.

Sun, S.S., and McDonough, W.F., 1989, Chemical and isotopic systematics of oceanic basalts: implications for mantle composition and processes, in Saunders, A.D., and Norry, M.G., eds., Magmatism in the Ocean Basins, Geological Society, London, Special Publications 42, p. 313-345.

Tobisch, O.T., McNulty, B.A., and Vernon, R.H., 1997, Microgranitoid enclave swarms in granitic plutons, central Sierra Nevada, California: Lithos, v. 40, p. 312-339.

Tobisch, O.T., Renne, P.R., and Saleeby, J.B., 1993, Deformation resulting from regional extension during pluton ascent and emplacement, central Sierra Nevada, California: Journal of Structural Geology, v. 15, p. 609-628.

Tobisch, O.T., Saleeby, J.B., Renne, P.R., McNulty, B., and Tong, W., 1995, Variations in deformation fields during development of a large-volume magmatic arc, central Sierra Nevada, California, Geological Society of America Bulletin, v. 107, p. 148166. 
Trail, D., Watson, E.B., and Tailby, N.D., 2012, Ce and Eu anomalies in zircon as proxies for oxidation state of magmas: Geochimica et Cosmochimica Acta, v. 97, p. 70-87, doi: 10.1016/j.gca.2012.08.032.

Valley, J.W., Lackey, J.S., Cavosie, A.J., Clechenko, C.C., Spicuzza, M.J., Basei, M.A.S., Bindeman, I.N., Ferreira, V.P., Sial, A.N., King, E.M., Peck, W.H., Sinha, A.K., and Wei, C.S., 2005, 4.4 billion years of crustal maturation; oxygen isotope ratios of magmatic zircon: Contributions to Mineralogy and Petrology, v. 150, p. 561-580.

Valley, J.W., 2003, Oxygen isotopes in zircon: Reviews in Mineralogy and Geochemistry, v. 53, p. 343-385.

Vervoort, J.D., Patchett, P.J., Söderlund, U., and Baker, M., 2004, Isotopic composition of $\mathrm{Yb}$ and the determination of $\mathrm{Lu}$ concentrations and $\mathrm{Lu} / \mathrm{Hf}$ ratios by isotope dilution using MC-ICPMS: Geochemistry, Geophysics, Geosystems, v. 5, no. 11, doi: 10.1029/2004GC000721.

Watson, E.B., and Cherniak, D.J., 1995, Oxygen diffusion in zircon: EOS, Transactions, American Geophysical Union, v. 76, p. 299.

Watson, E.B., and Harrison, T.M., 2005, Zircon thermometer reveals minimum melting conditions on earliest Earth: Science, v. 308, p. 841-844.

Watson, E.B., Wark, D.A., and Thomas, J.B., 2006, Crystallization thermometers for zircon and rutile: Contributions to Mineralogy and Petrology, v. 151, p. 413-433.

Watson, E.B., 1996, Dissolution, growth and survival of zircons during crustal fusion; kinetic principles, geological models and implications for isotopic inheritance: Geological Society of America Special Paper, v. 315, p. 43-56.

Watson, E.B., and Harrison, T.M., 1983, Zircon saturation revisited; temperature and composition effects in a variety of crustal magma types: Earth and Planetary Science Letters, v. 64, p. 295-304

Wenner, J.M., and Coleman, D.S., 2004, Magma mixing and Cretaceous crustal growth: geology and geochemistry of granites in the Central Sierra Nevada Batholith, California: International Geology Review, v. 46, p. 880-903.

Žák, J., and Paterson, S.R., 2005, Characteristics of internal contacts in the Tuolumne Batholith, central Sierra Nevada, California (USA): implications for episodic emplacement and physical processes in a continental arc magma chamber: Geological Society of America Bulletin, v. 117, p. 1242-1255. 


\section{APPENDIX A: Sample Locations and Descriptions}

\begin{tabular}{llll} 
Sample & UTM E & UTM N & Description \\
\hline CS01 & 291684 & 4132107 & PJs; Mica-Schist \\
CS03 & 290754 & 4140169 & Mafic enclave in Cow Meadow granodiorite \\
CS05 & 291684 & 4153057 & Equigranular Mount Givens granodiorite \\
CS06 & 291619 & 4153102 & Porphyritic Mount Givens granodiorite \\
CS07 & 284392 & 4150466 & Porphyritic Mount Givens granodiorite \\
CS09 & 324161 & 4113867 & Courtright Aplite, Leucogranite \\
CS10 & 325843 & 4106077 & Equigranular Mount Givens granodiorite \\
CS12 & 325204 & 4105211 & Porphyritic Mount Givens granodiorite \\
CS13 & 322399 & 4136210 & Felsic sheet in Givens \\
CS15 & 321161 & 4135733 & Intermediate mass from mixing zone \\
CS16 & 321161 & 4135733 & Equigranular Mount Givens Granodiorite; \\
& & & mixing zone \\
CS19 & 317841 & 4134329 & Mafic body \\
CS20B & 317871 & 4134400 & Enclaves in hybrid \\
CS21 & 322445 & 4135412 & Equigranular Mount Givens granodiorite \\
CS22 & 322450 & 4134374 & Equigranular Mount Givens granodiorite \\
CS23 & 321567 & 4132948 & Equigranular Mount Givens granodiorite \\
CS24 & 320422 & 4131241 & Equigranular Mount Givens granodiorite \\
CS25 & 317179 & 4132285 & Equigranular Mount Givens granodiorite \\
CS26 & 312474 & 4127476 & Equigranular Mount Givens granodiorite \\
11 SN34 & 299156 & 4157996 & Equigranular Mount Givens granodiorite \\
11 SN35 & 297831 & 4153335 & Equigranular Mount Givens granodiorite \\
11 SN36 & 296809 & 4145484 & Equigranular Mount Givens granodiorite \\
11 SN37 & 295467 & 4145248 & Aplite of Jackass Rock \\
11 SN38 & 291268 & 4140381 & Cow Meadow granodiorite \\
11 SN39 & 290815 & 4140069 & Cow Meadow granodiorite \\
11 SN40 & 289492 & 4139770 & Porphyritic Mount Givens granodiorite \\
$11 S N 41$ & 288203 & 4137702 & Equigranular Mount Givens granodiorite \\
& & &
\end{tabular}


APPENDIX B: Cathodoluminescence Images with Indexed Analysis Spots

CS01

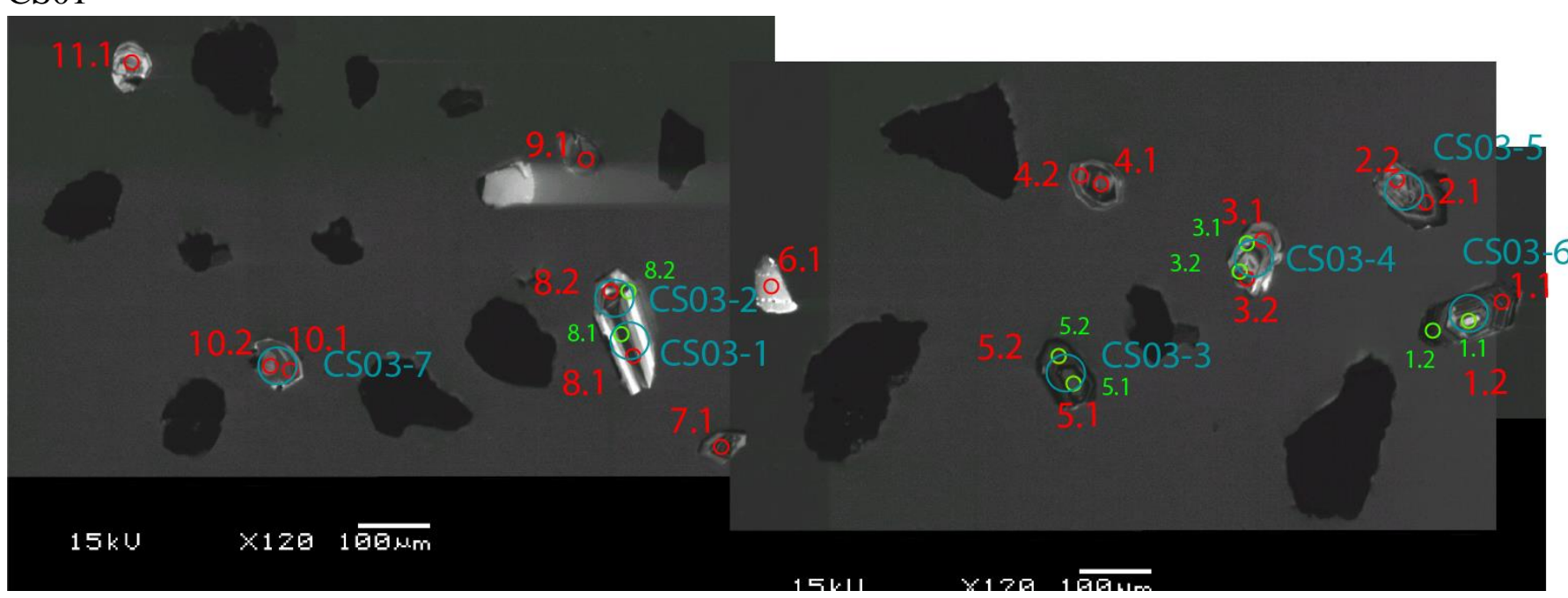

$\mathrm{CS} 03$

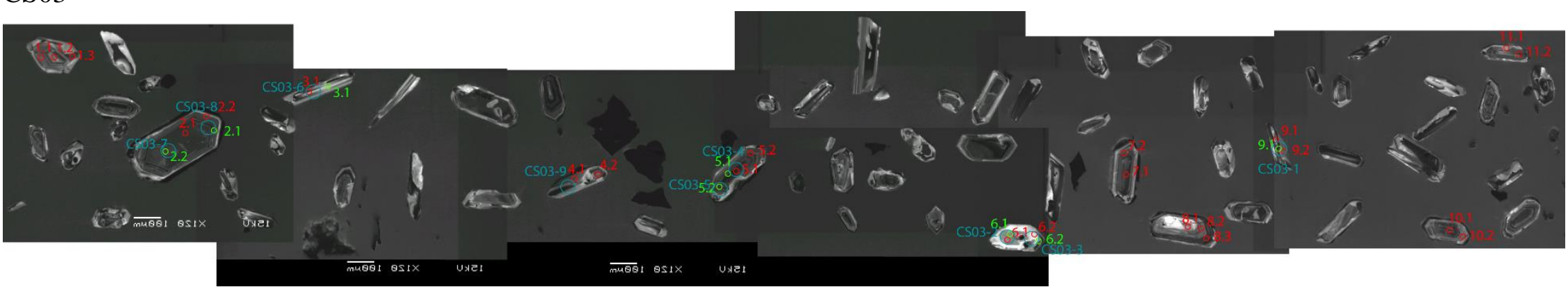

* SHRIMP trace element spots in red, SIMS oxygen spots in green, LA-ICPMS Hf spots in blue. CS07 


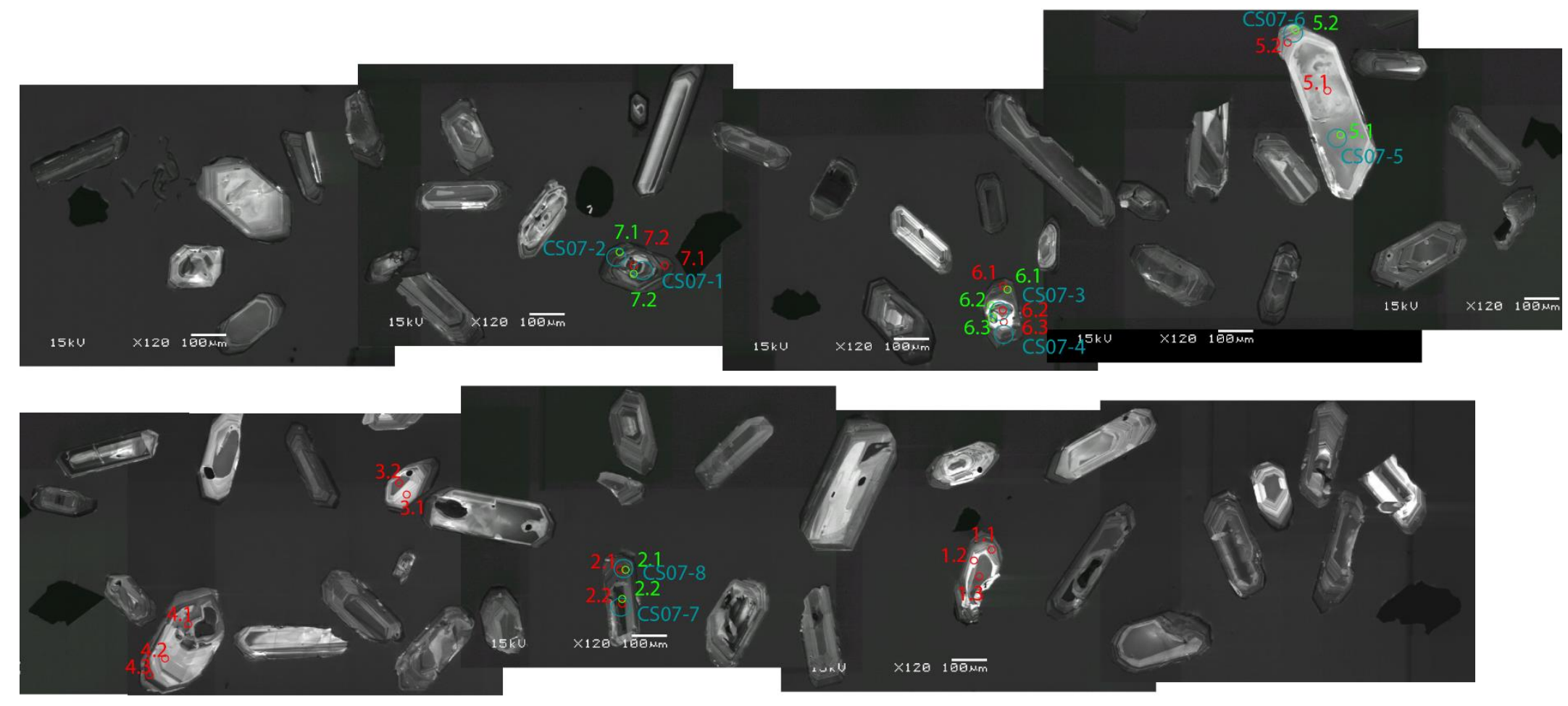

* SHRIMP trace element spots in red, SIMS oxygen spots in green, LA-ICPMS Hf spots in blue.

CS10 


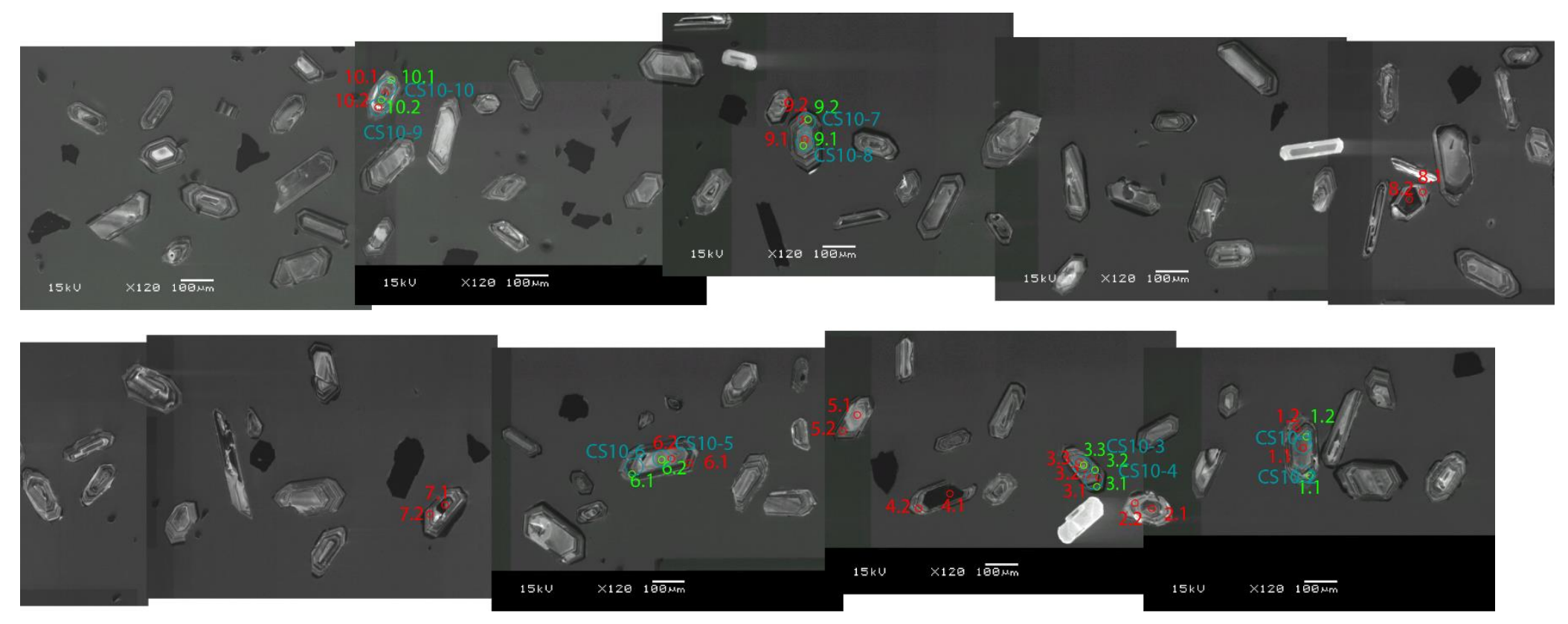

* SHRIMP trace element spots in red, SIMS oxygen spots in green, LA-ICPMS Hf spots in blue. CS13 

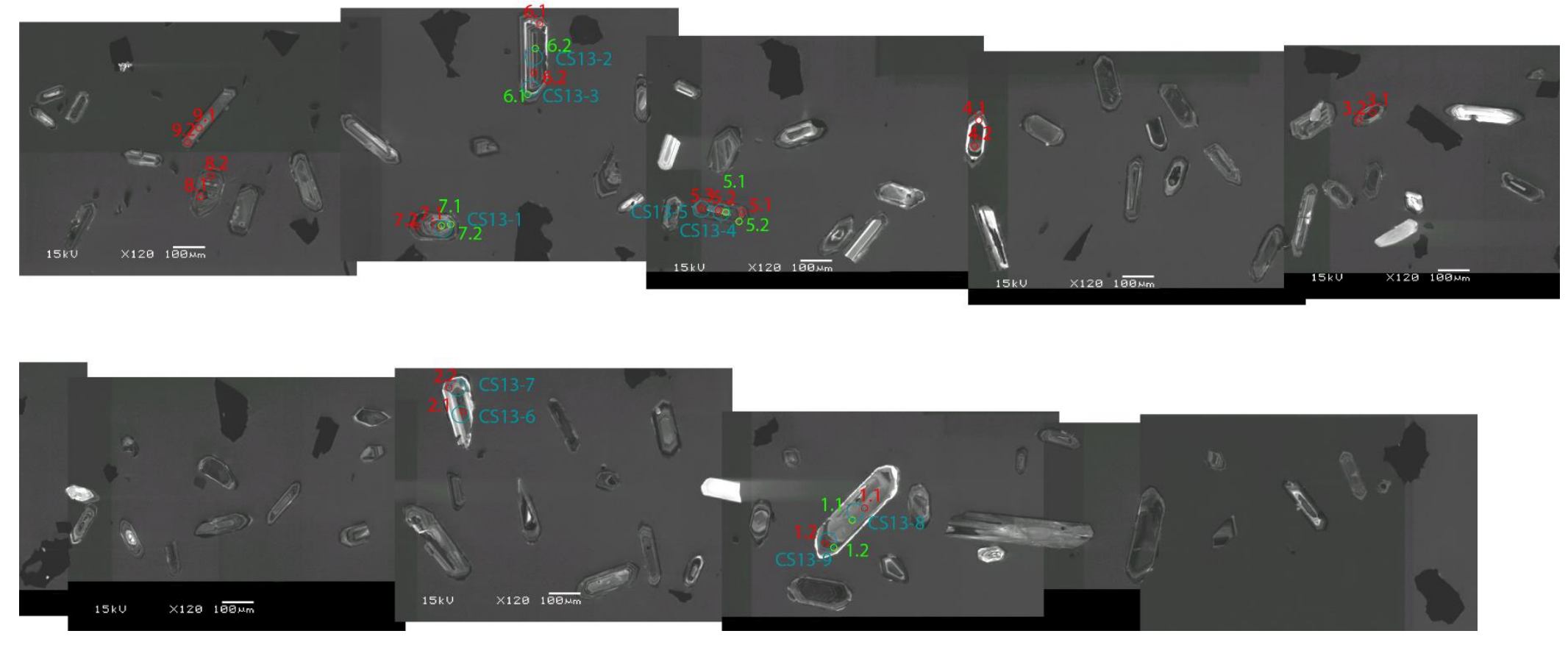

* SHRIMP trace element spots in red, SIMS oxygen spots in green, LA-ICPMS Hf spots in blue. CS19 


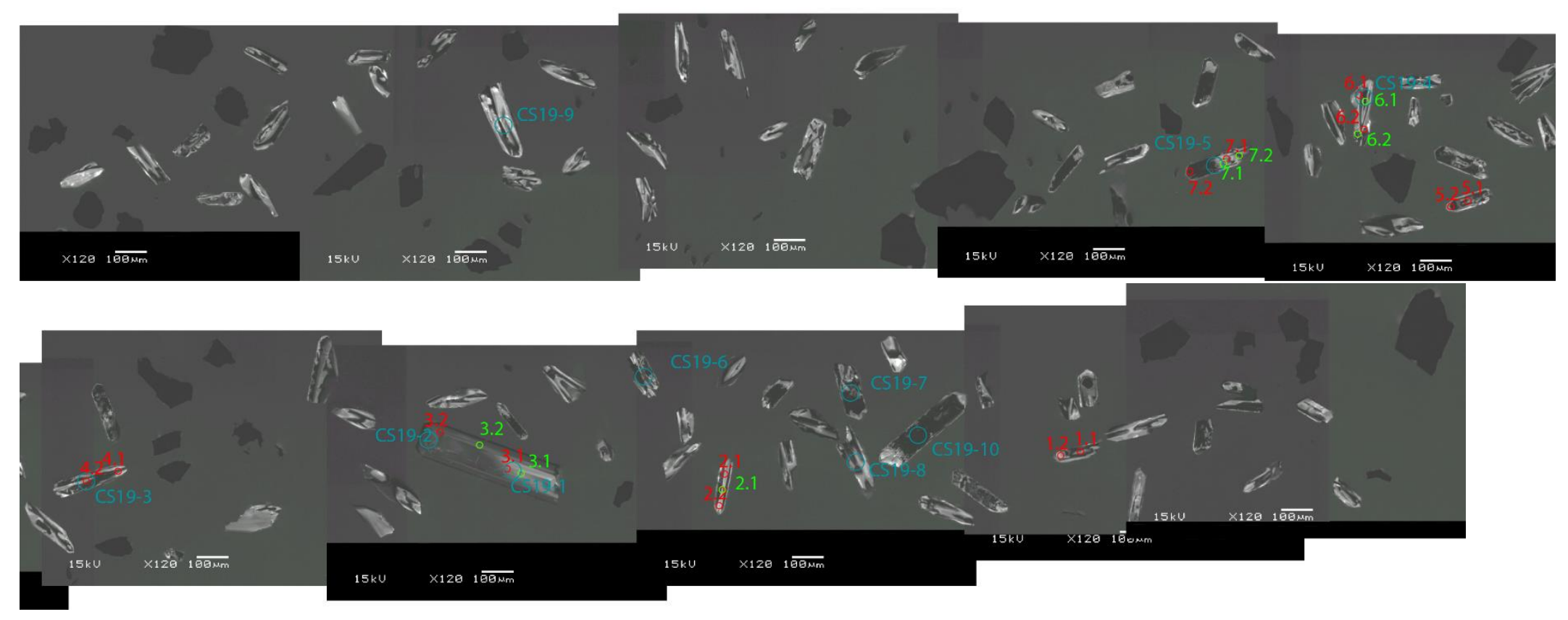

* SHRIMP trace element spots in red, SIMS oxygen spots in green, LA-ICPMS Hf spots in blue.

CS25 


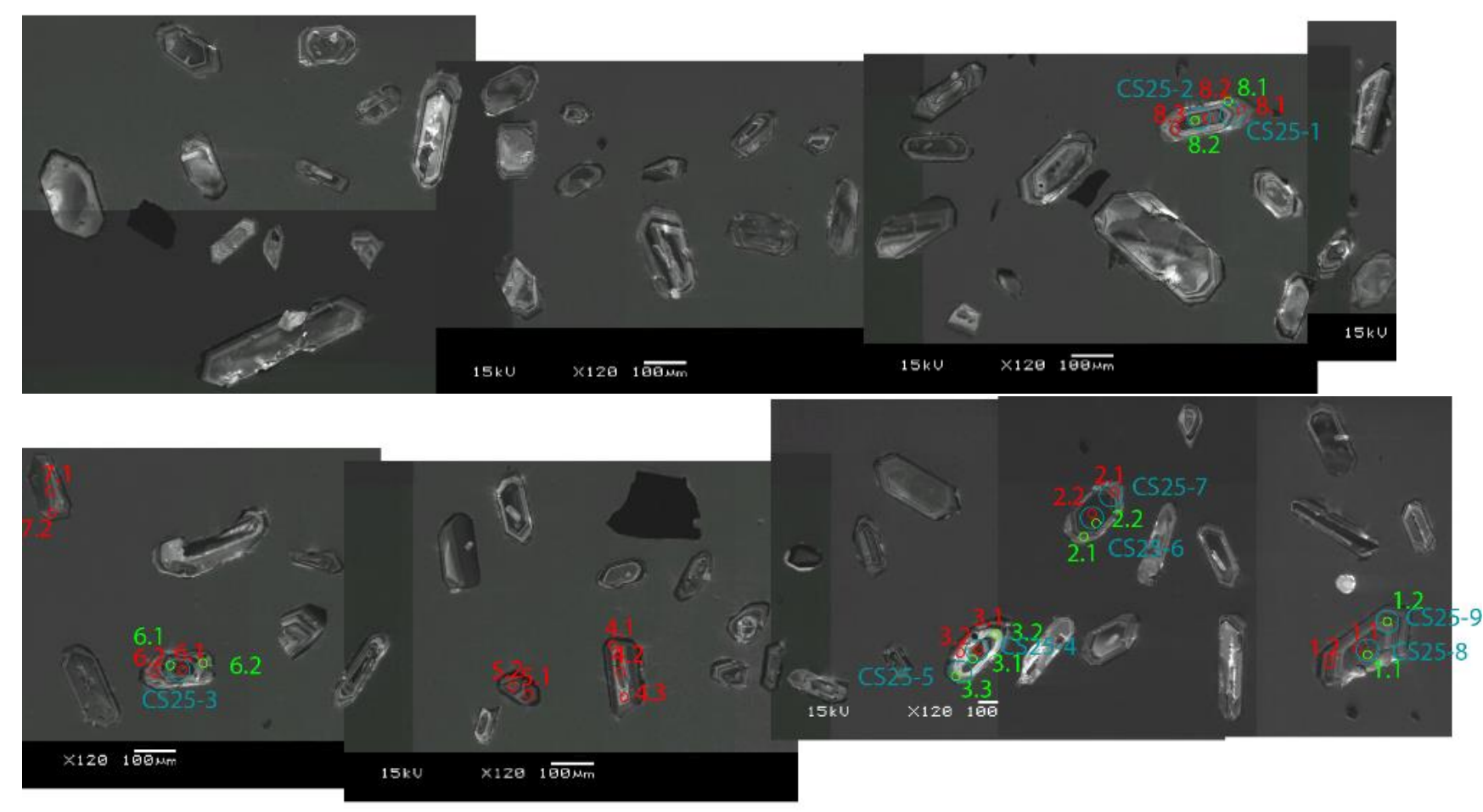

* SHRIMP trace element spots in red, SIMS oxygen spots in green, LA-ICPMS Hf spots in blue. $11 \mathrm{SN} 34$ 


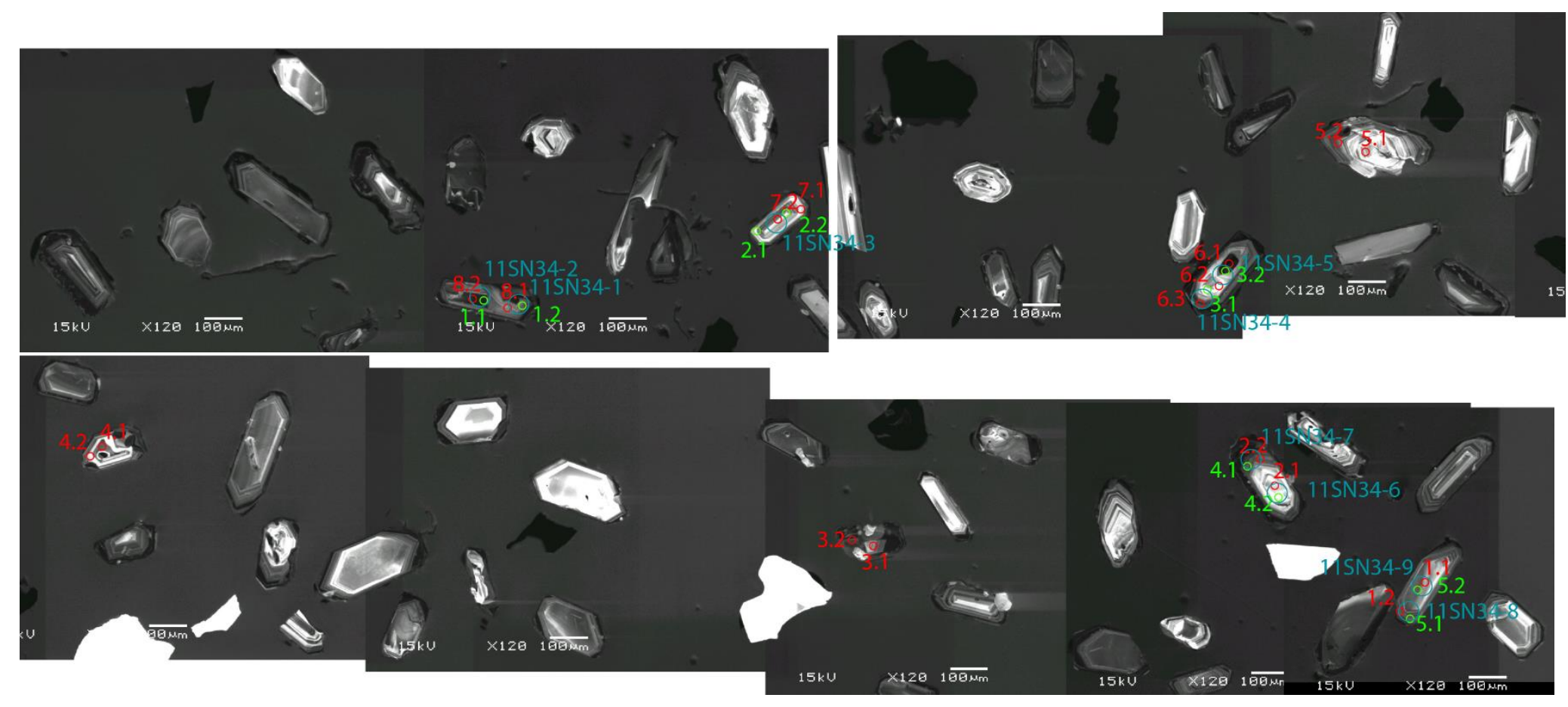

* SHRIMP trace element spots in red, SIMS oxygen spots in green, LA-ICPMS Hf spots in blue. $11 \mathrm{SN} 36$ 


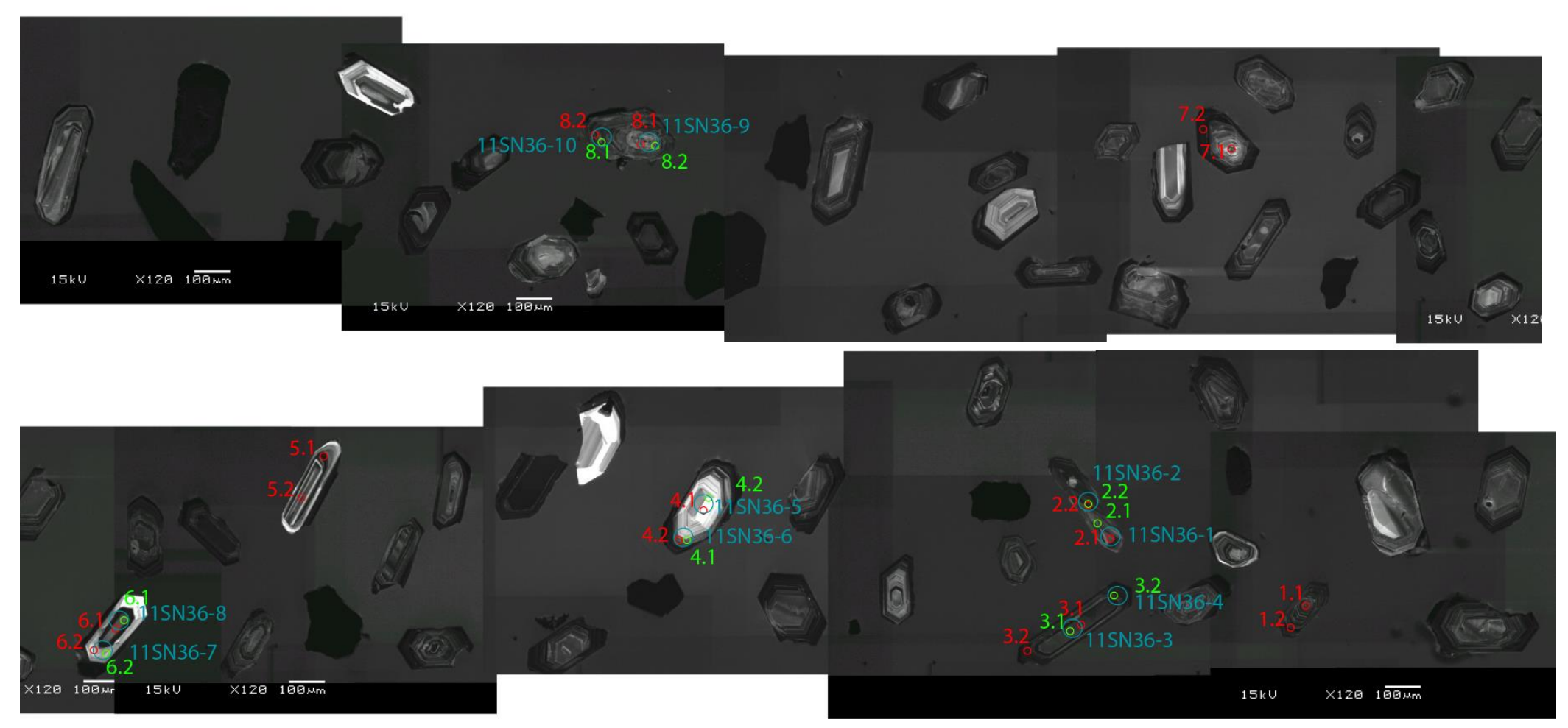

* SHRIMP trace element spots in red, SIMS oxygen spots in green, LA-ICPMS Hf spots in blue. $11 \mathrm{SN} 37$ 


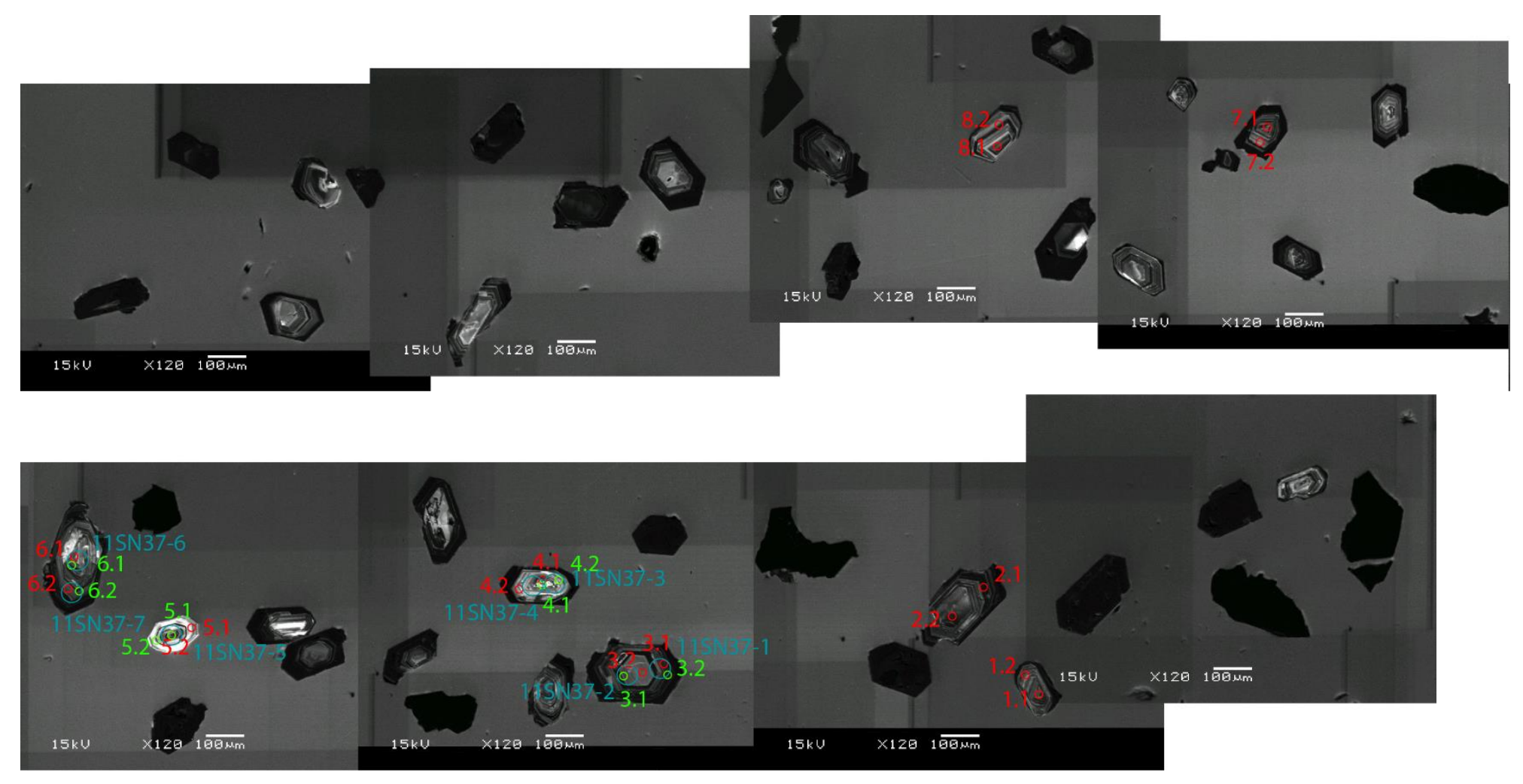

* SHRIMP trace element spots in red, SIMS oxygen spots in green, LA-ICPMS Hf spots in blue. $11 \mathrm{SN} 38$ 


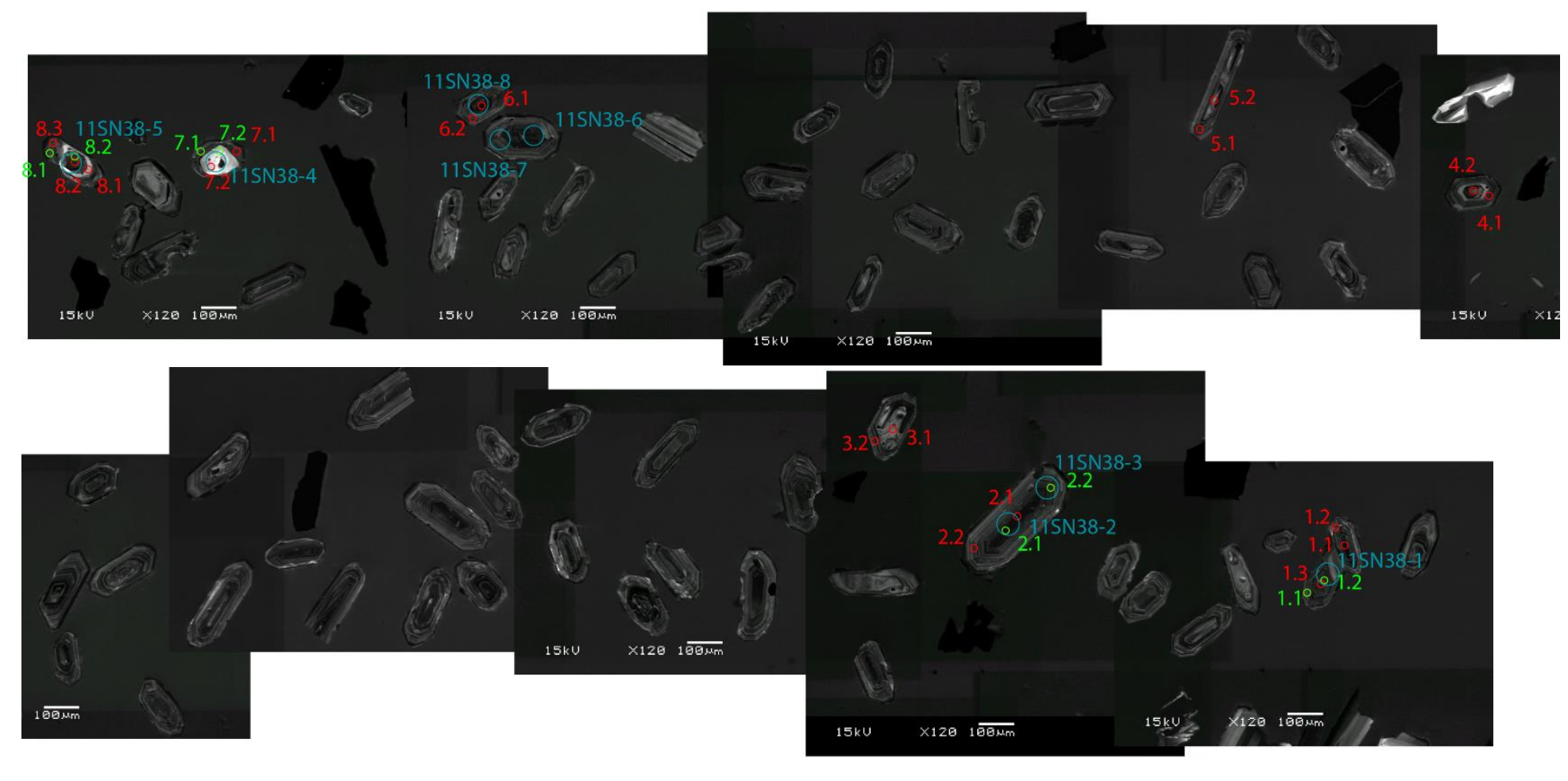

* SHRIMP trace element spots in red, SIMS oxygen spots in green, LA-ICPMS Hf spots in blue. $11 \mathrm{SN} 40$ 


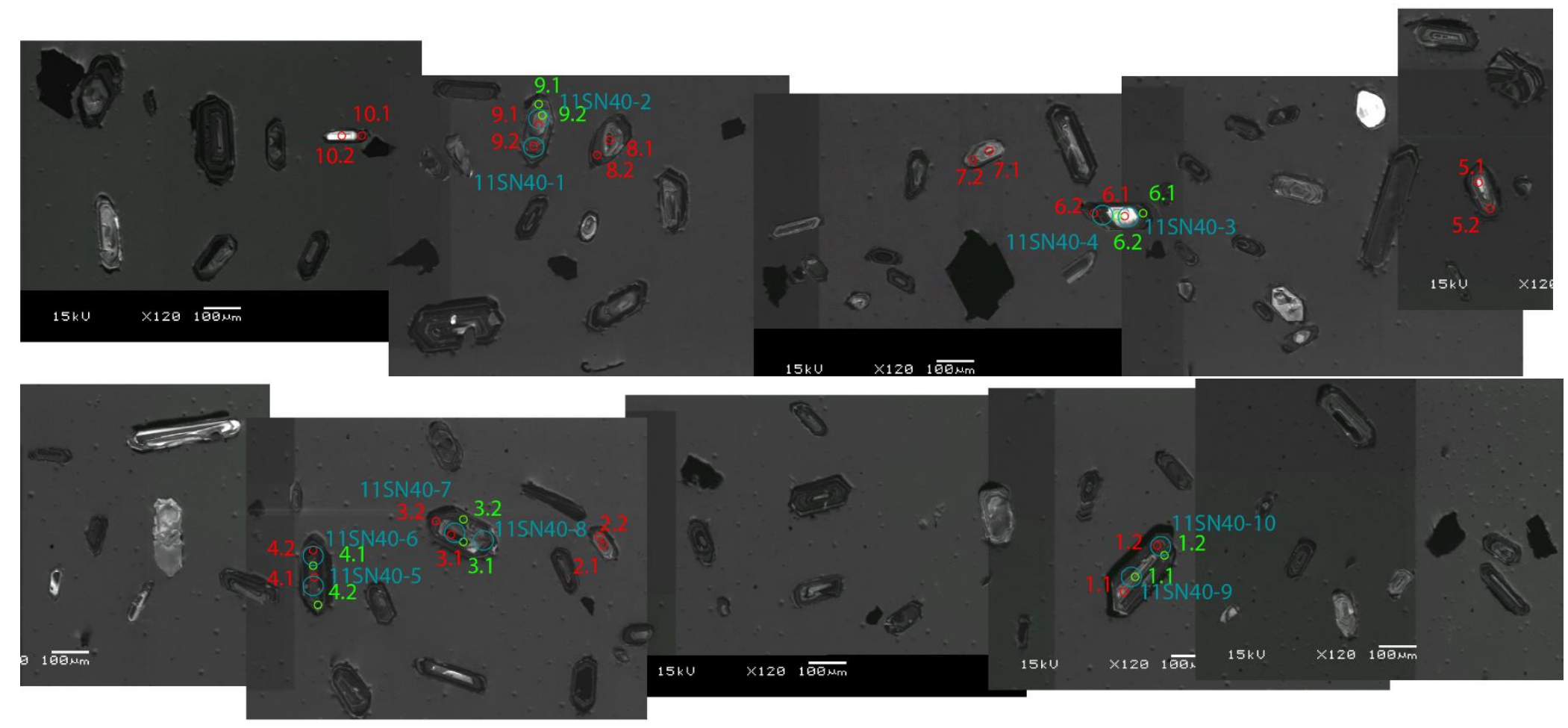

* SHRIMP trace element spots in red, SIMS oxygen spots in green, LA-ICPMS Hf spots in blue.

$11 \mathrm{SN} 41$ 


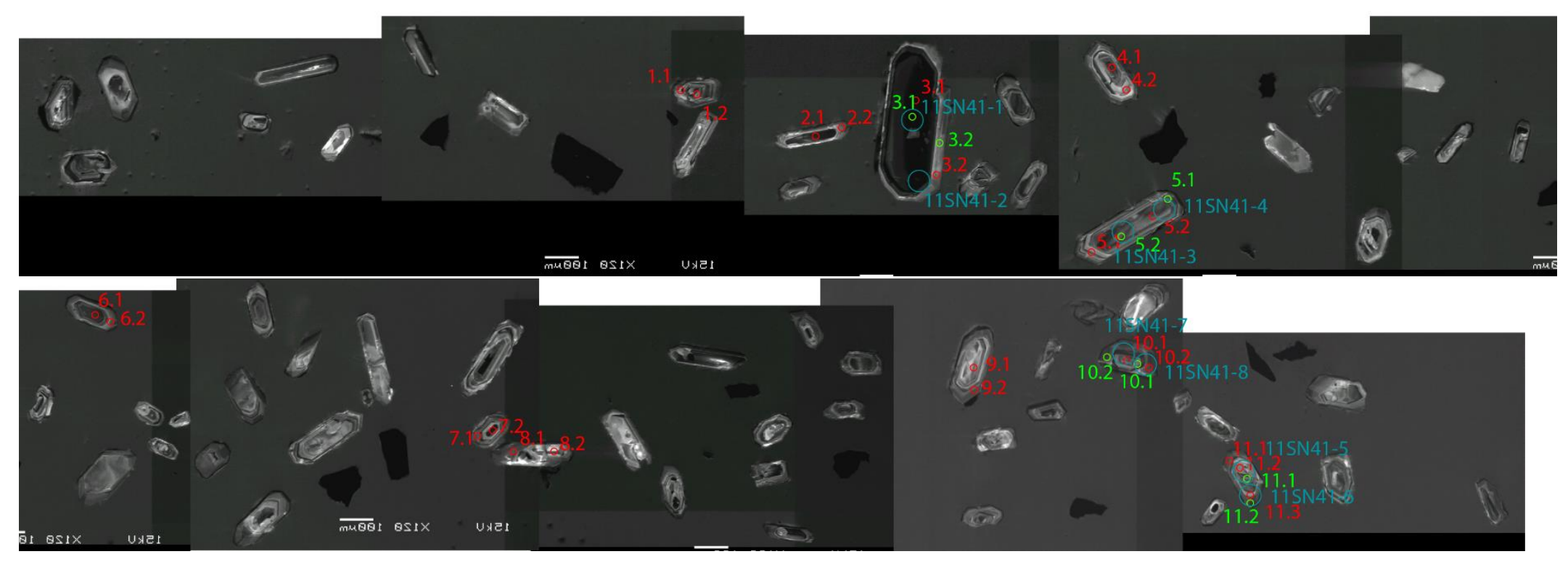

* SHRIMP trace element spots in red, SIMS oxygen spots in green, LA-ICPMS Hf spots in blue. 
Appendix C: Cathodoluminesence Images with $\delta 180$, \&Hf, and Trace Element Concentrations

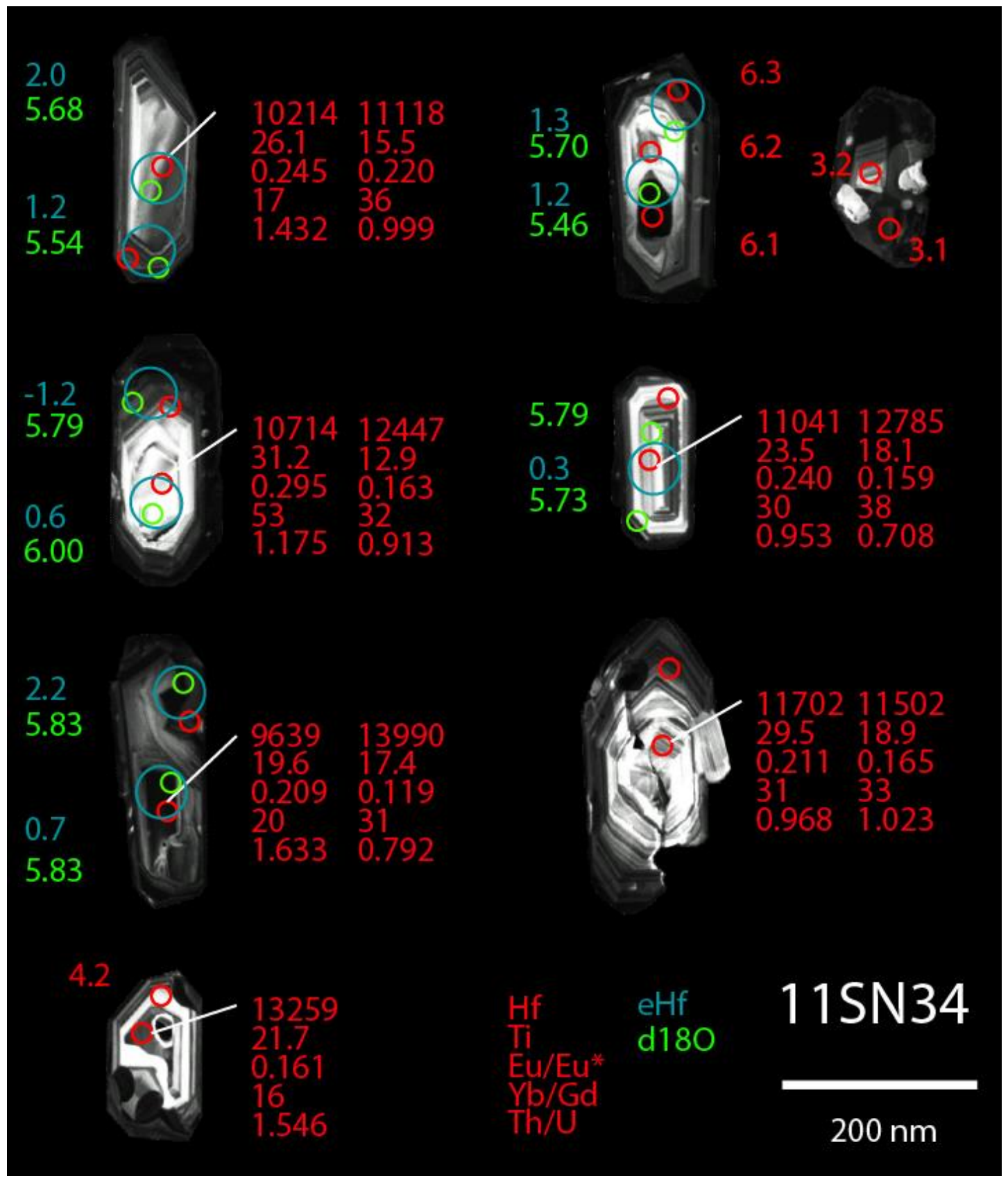




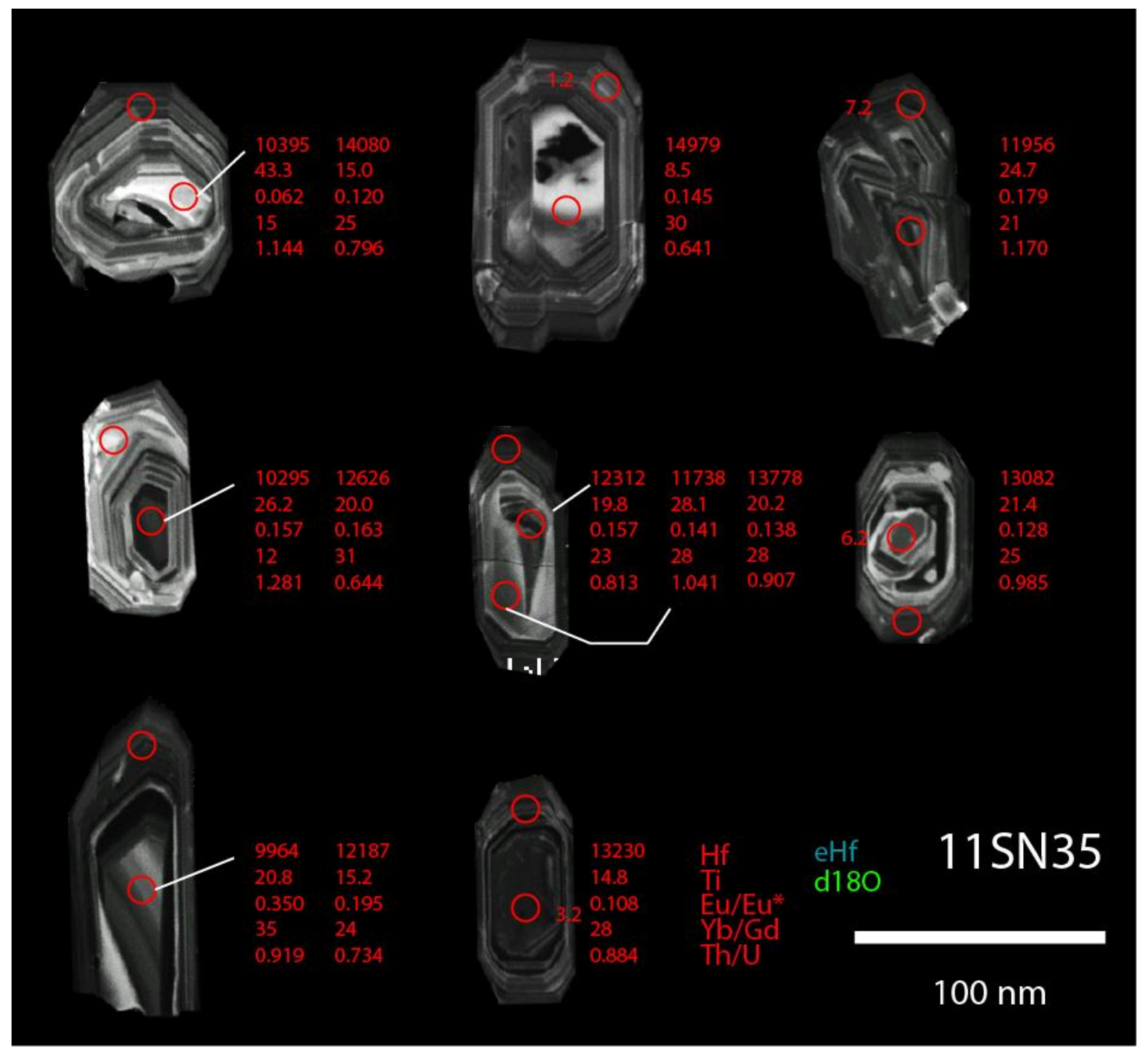




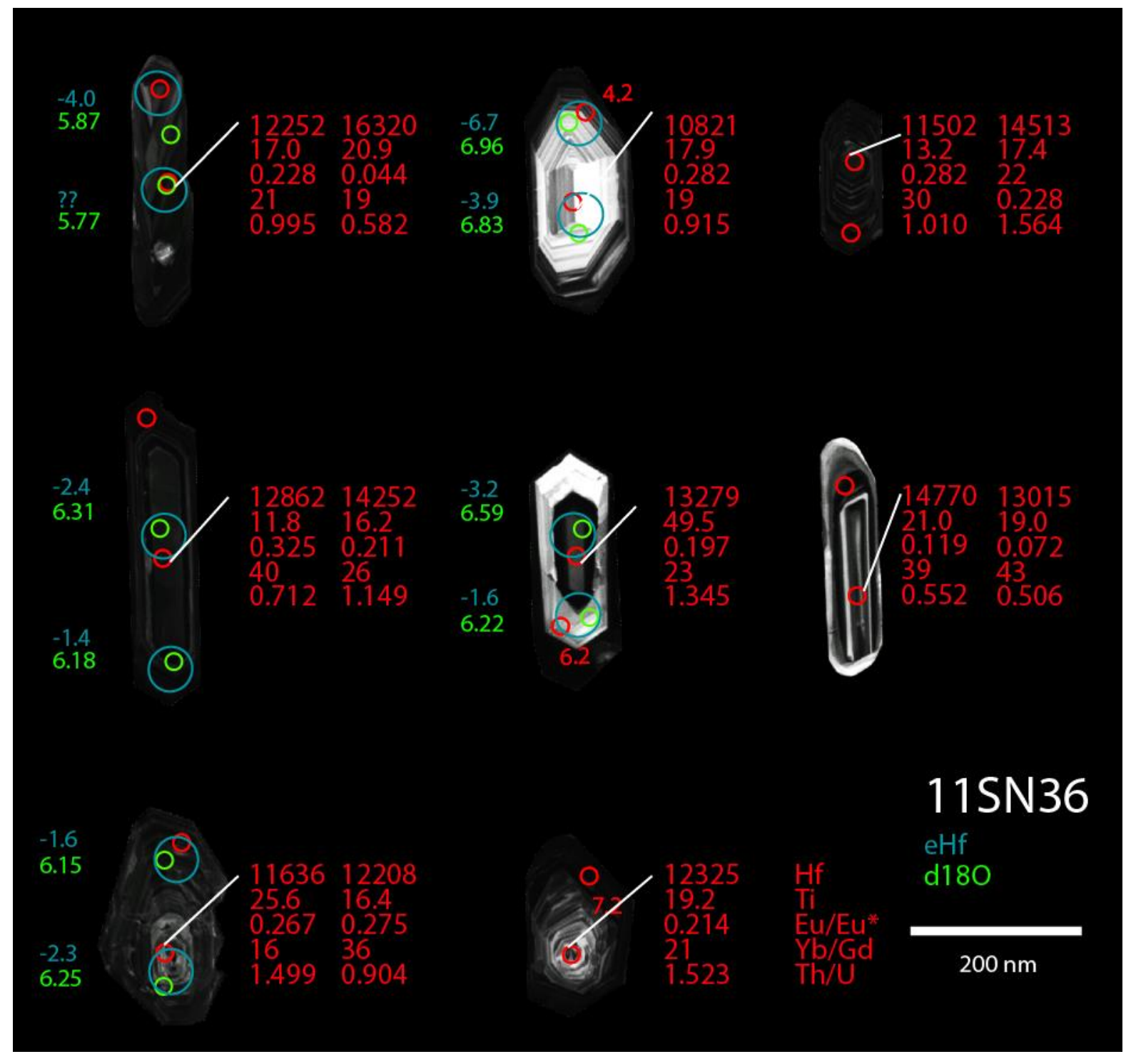




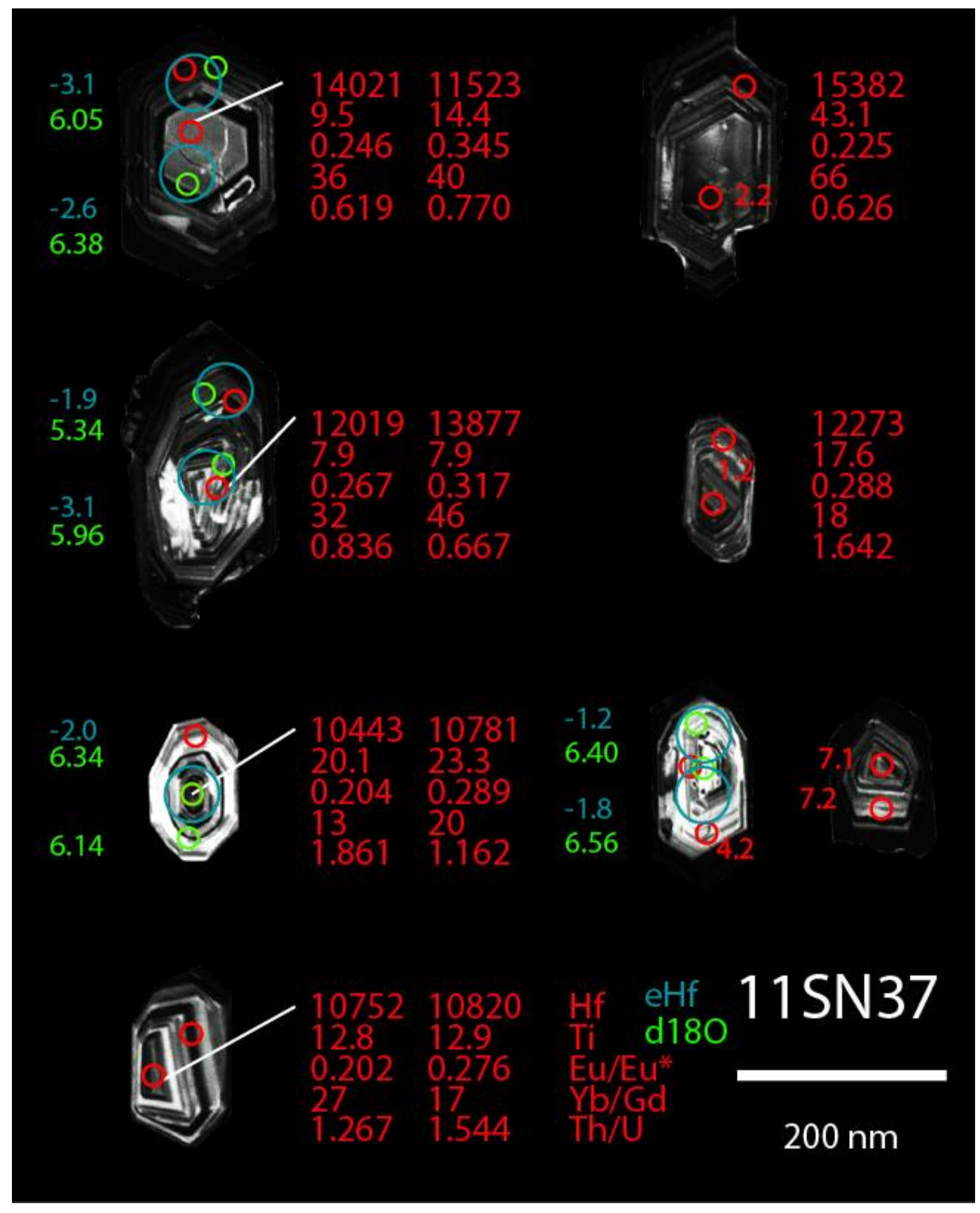




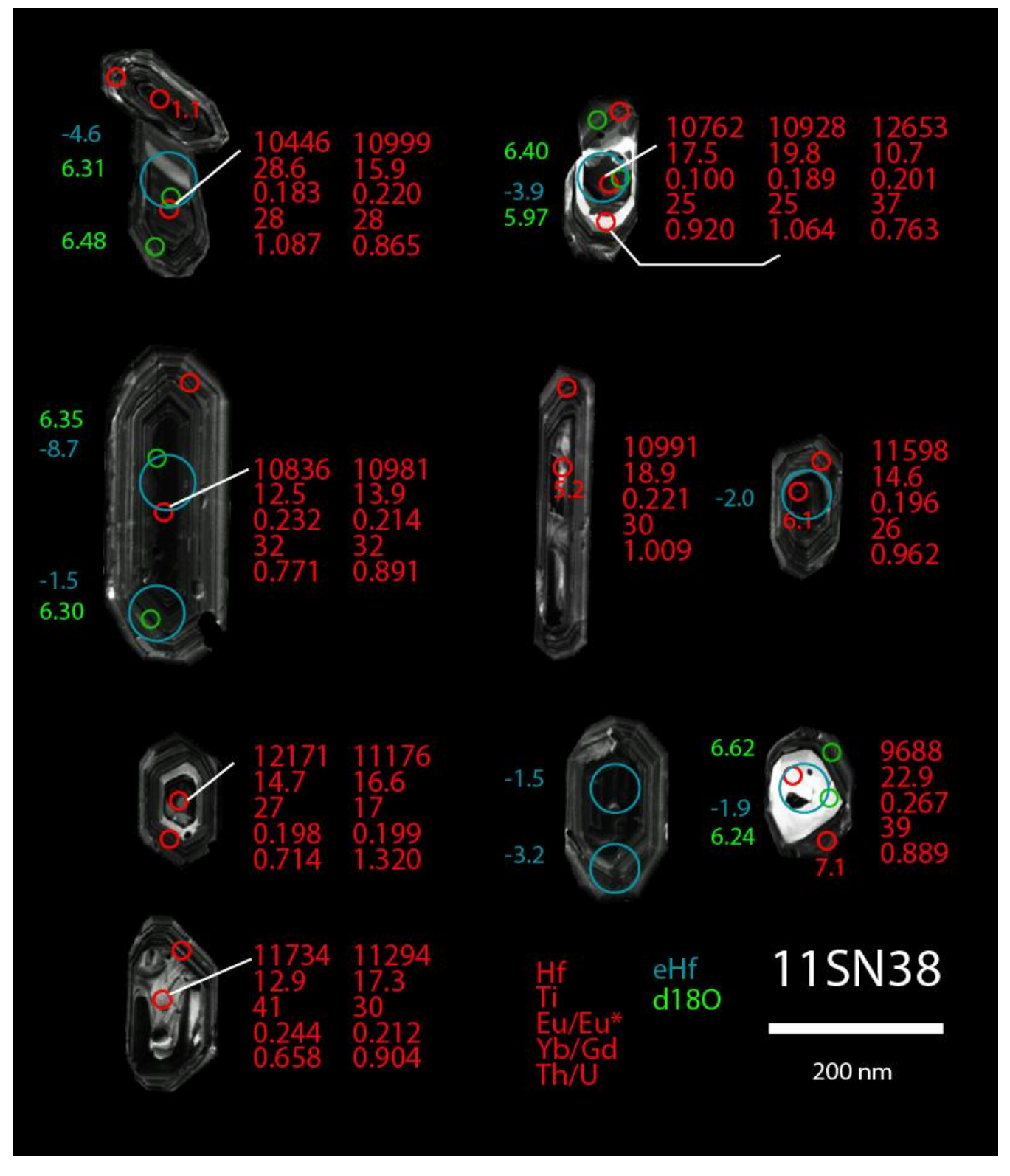




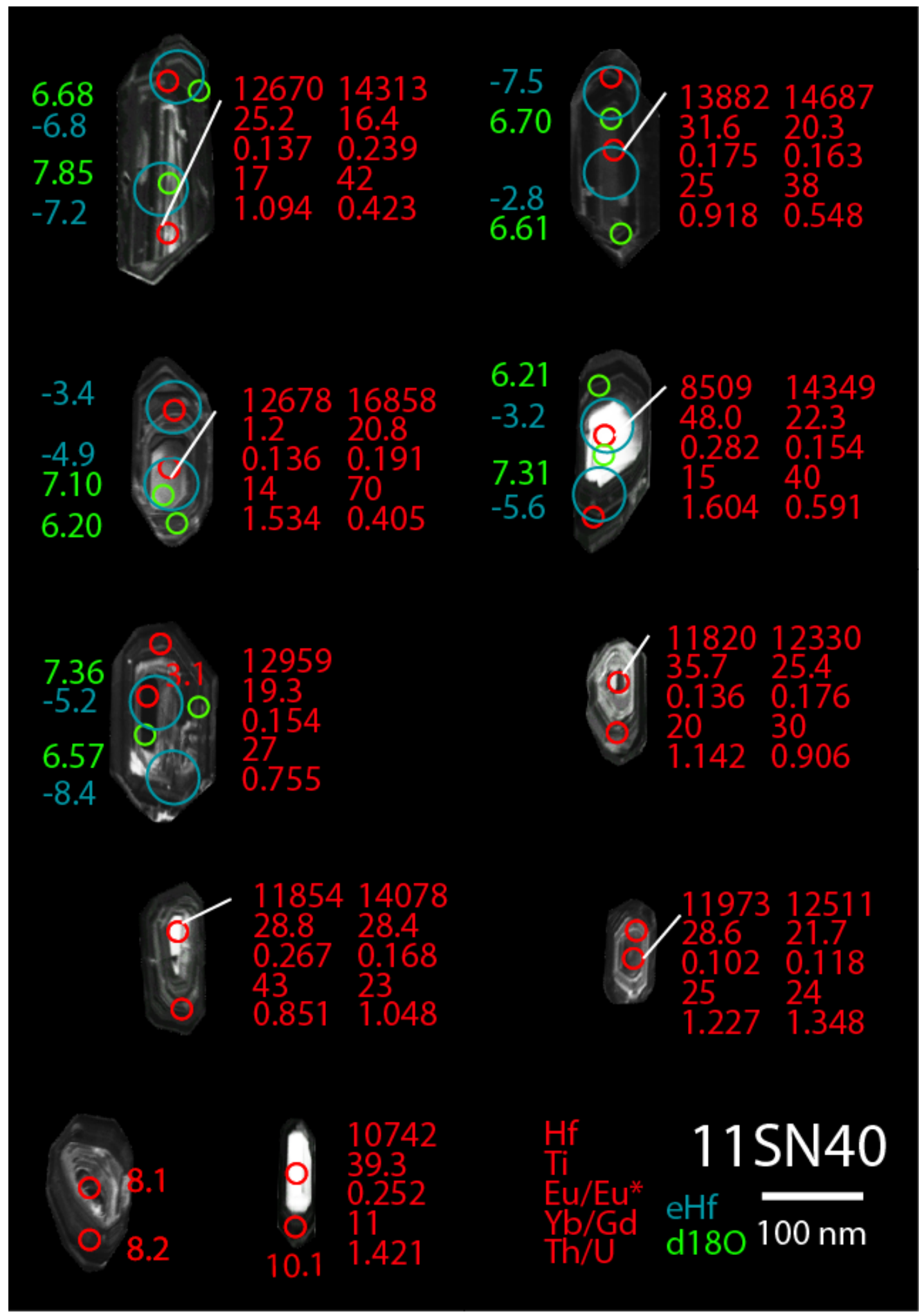




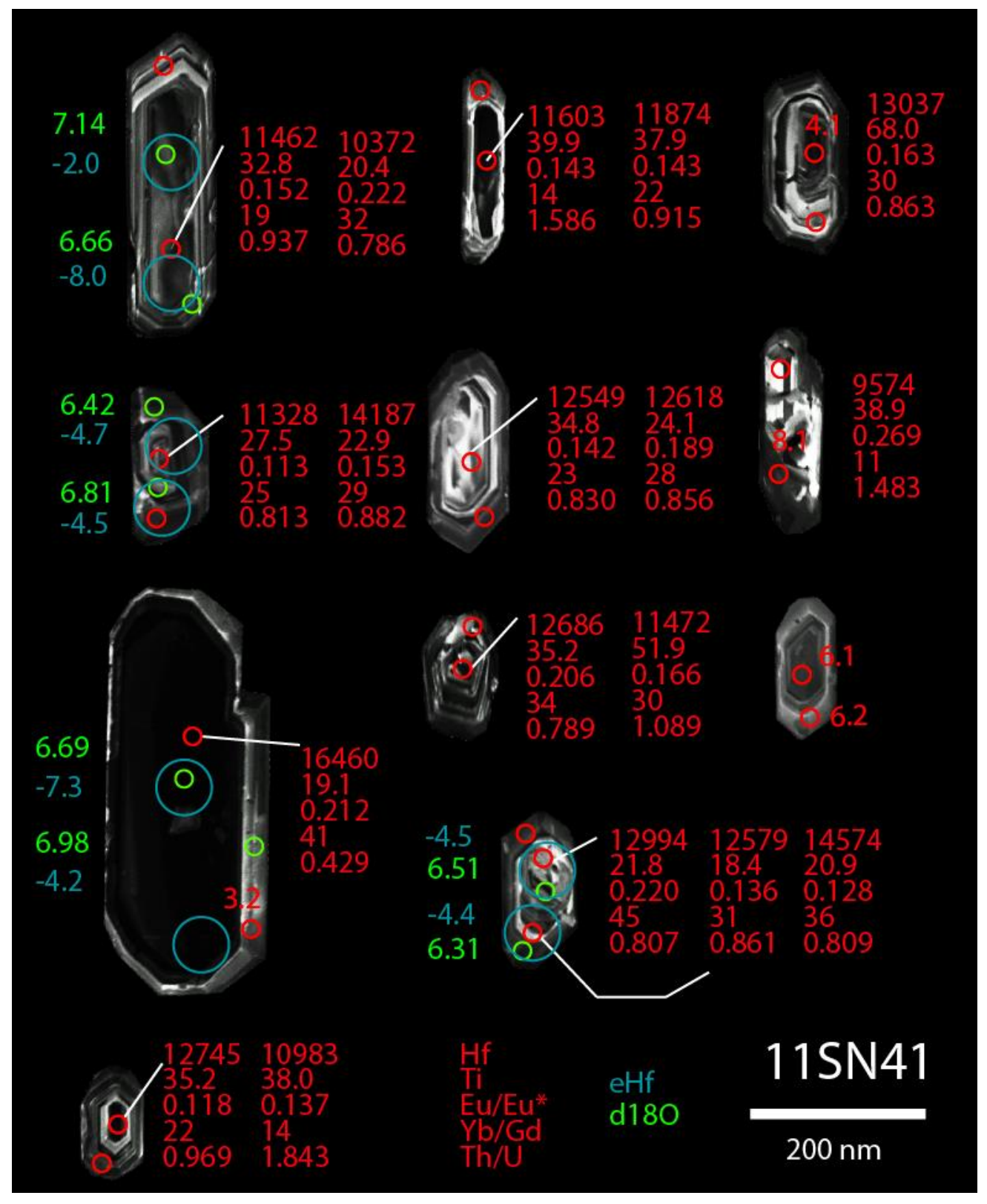



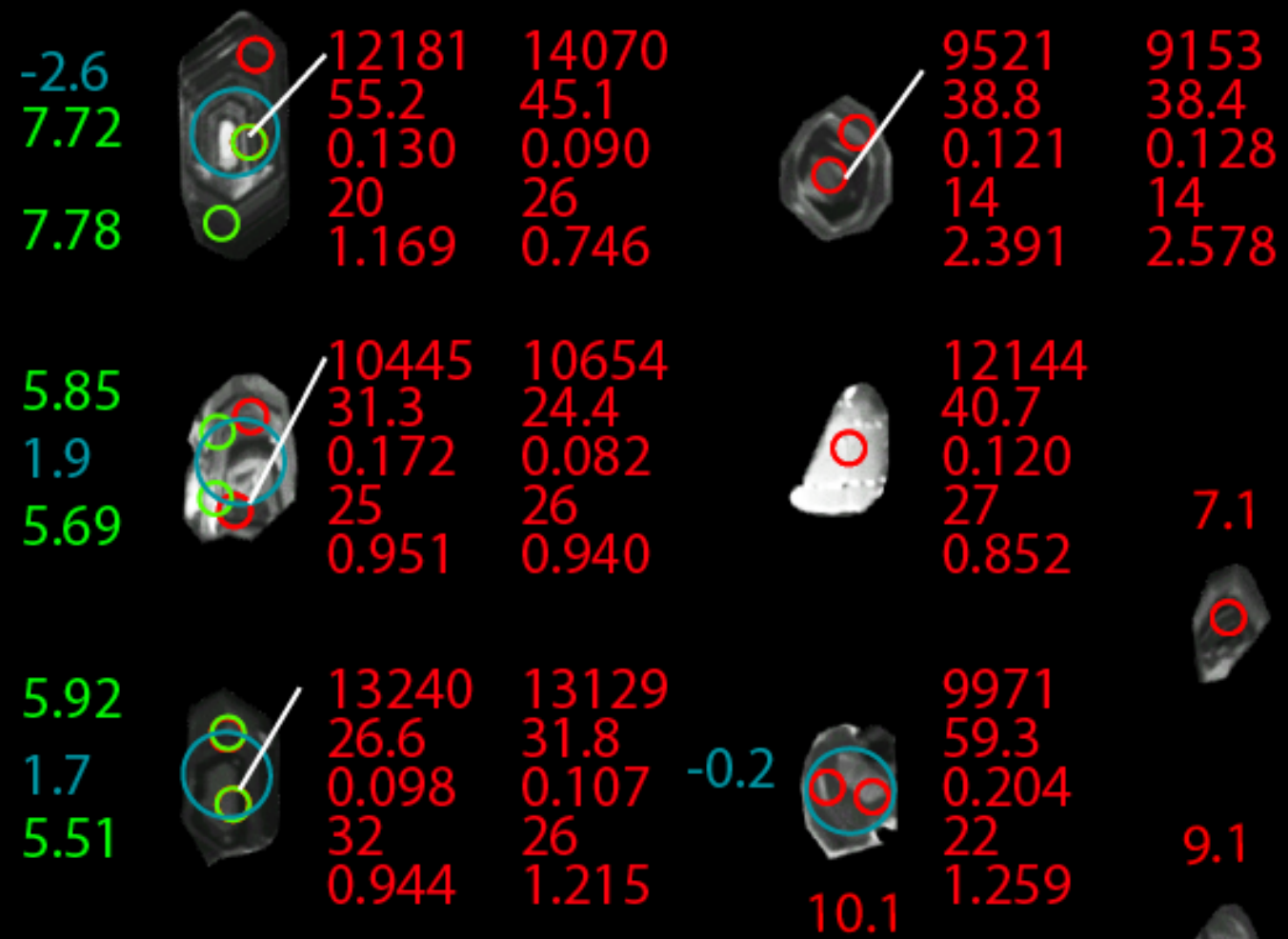
6.98 (a) $9754 \quad 8949$
6.98
-.9
5.89
0.6

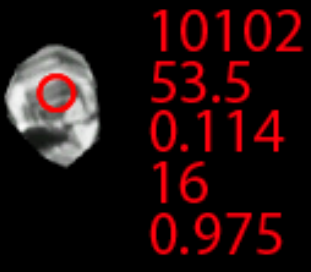

7.1

9.1
$\begin{array}{lll} & 12289 \\ -6.7 & 19.2 \\ (3) & 0.127 \\ 3.2 & 27 \\ 2.27 & 0.898\end{array}$

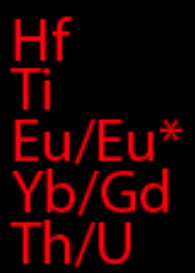
eHf
d180
CS01
$200 \mathrm{~nm}$ 


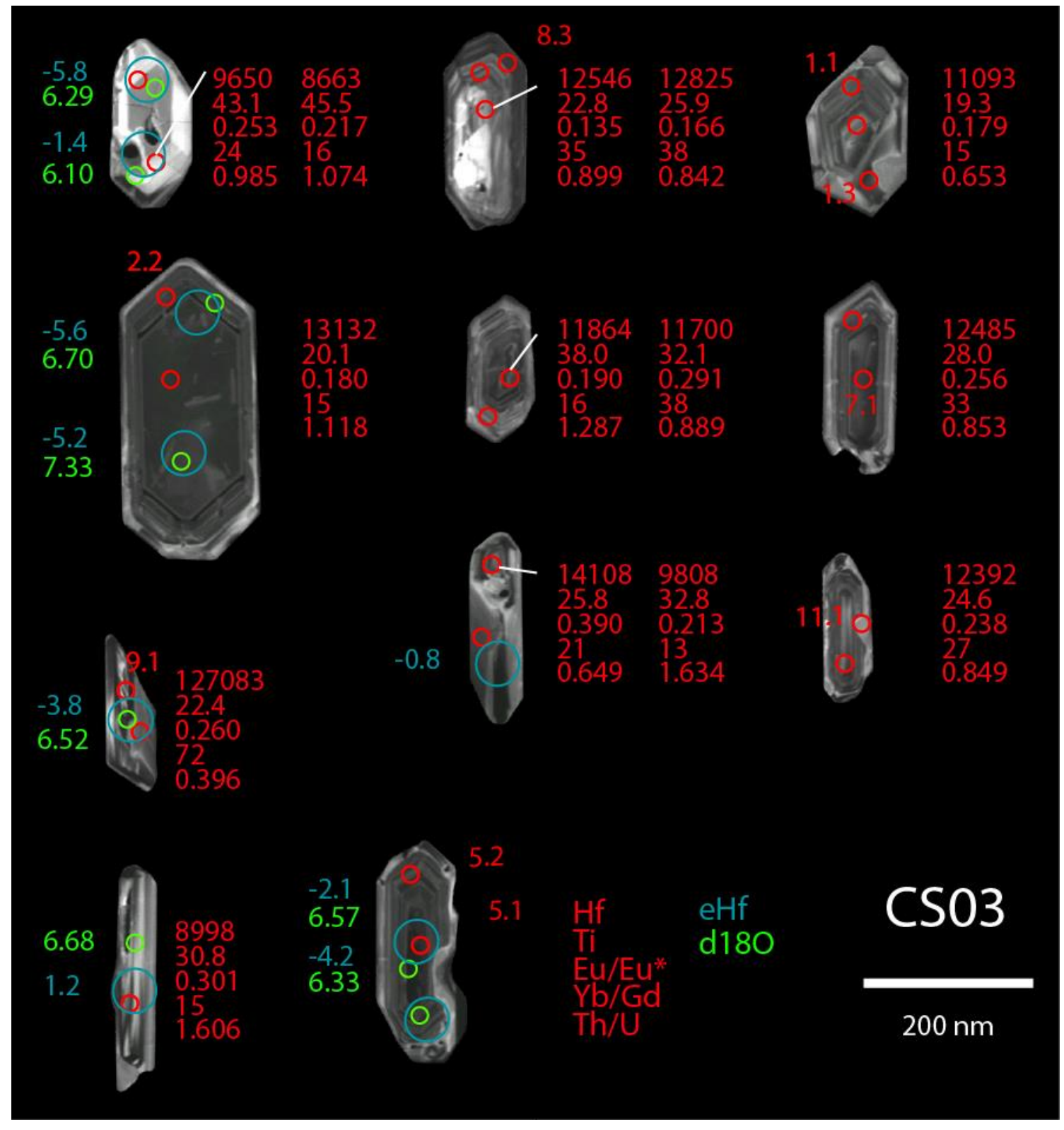




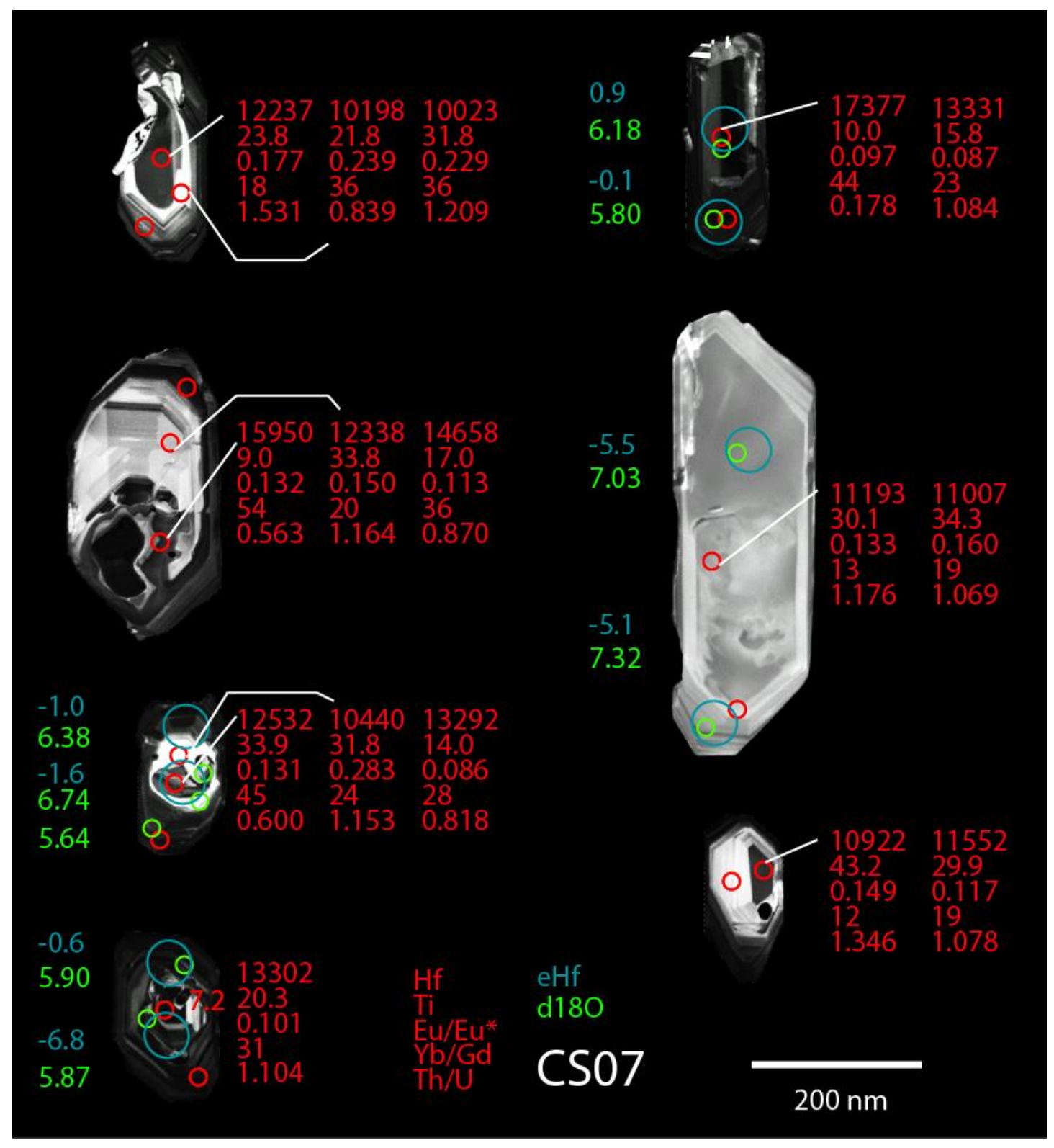




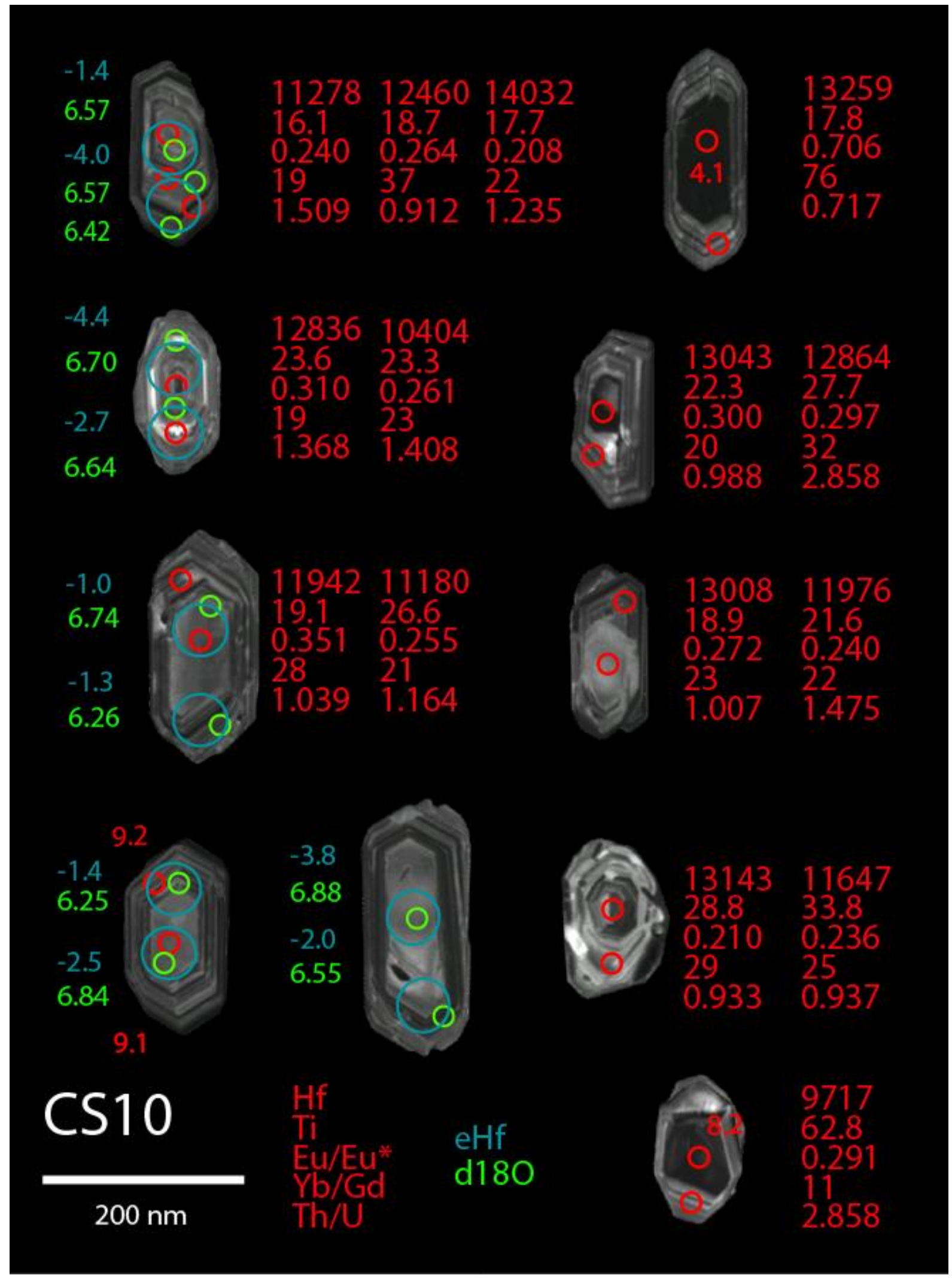




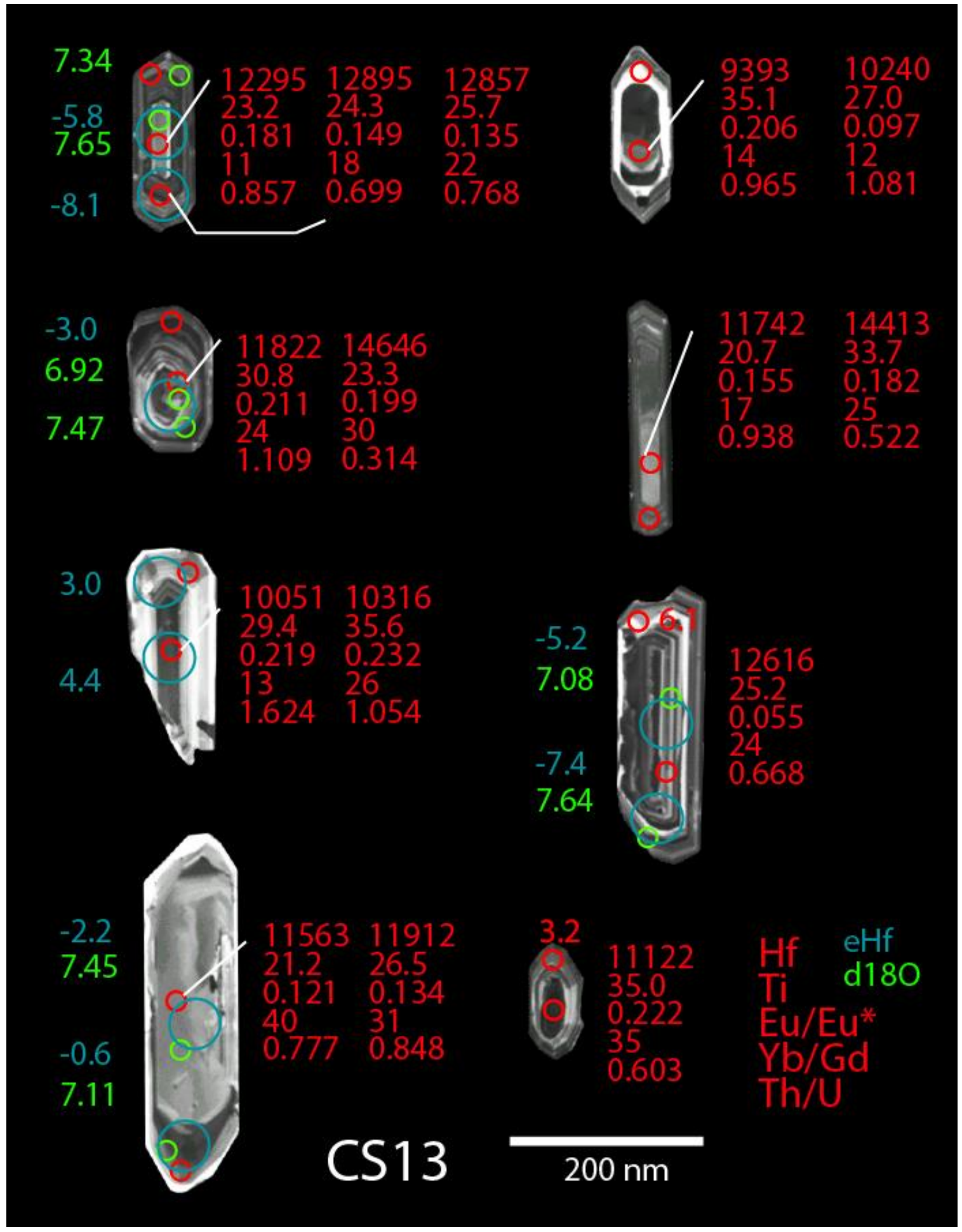




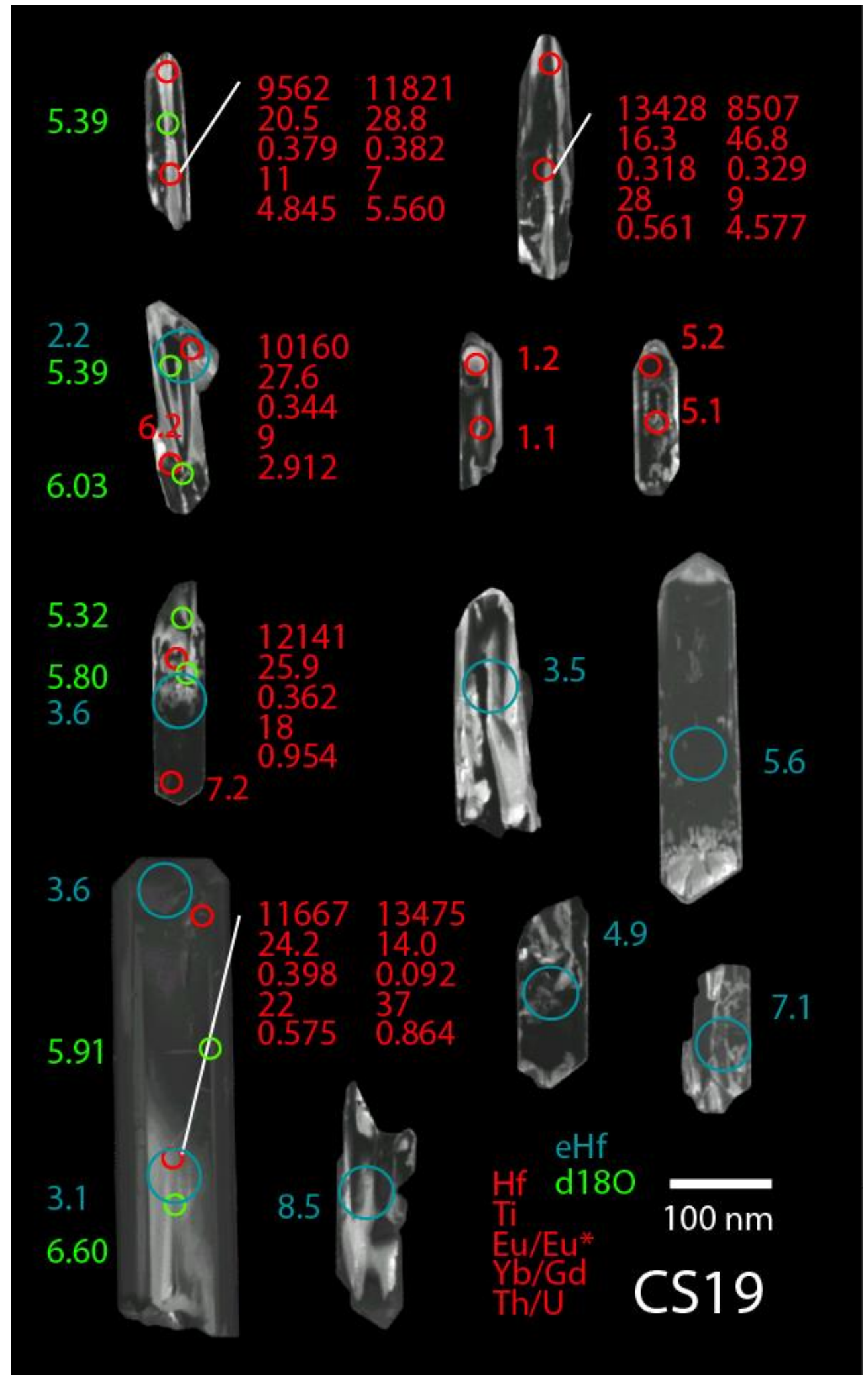




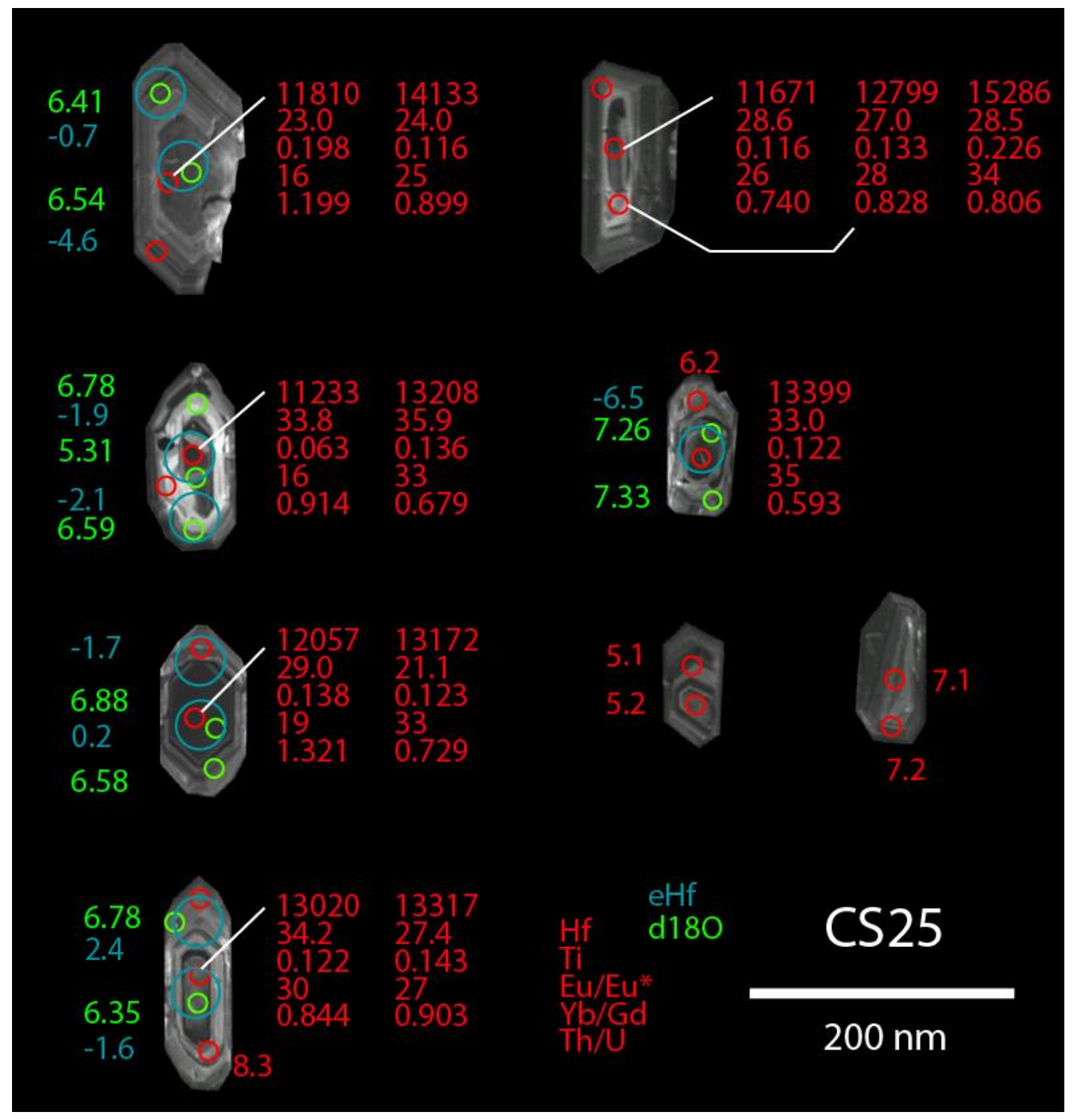




\section{APPENDIX D: Whole Rock Data}

Normalized Major Elements

\begin{tabular}{|c|c|c|c|c|c|c|c|c|c|c|c|}
\hline & $\mathrm{SiO} 2$ & $\mathrm{TiO} 2$ & $\mathrm{~A} 12 \mathrm{O} 3$ & $\mathrm{FeO}^{*}$ & $\mathrm{MnO}$ & $\mathrm{MgO}$ & $\mathrm{CaO}$ & $\mathrm{Na} 2 \mathrm{O}$ & $\mathrm{K} 2 \mathrm{O}$ & $\mathrm{P} 2 \mathrm{O} 5$ & Total \\
\hline CS01 & 59.98 & 1.068 & 16.77 & 6.71 & 0.317 & 3.47 & 5.72 & 2.59 & 3.11 & 0.264 & 100 \\
\hline $\mathrm{CS} 03$ & 50.83 & 1.399 & 18.96 & 10.33 & 0.22 & 5.16 & 5.87 & 4.16 & 2.75 & 0.324 & 100 \\
\hline CS05 & 61.98 & 0.736 & 17.49 & 5.57 & 0.107 & 2.32 & 5.22 & 4 & 2.39 & 0.186 & 100 \\
\hline CS06 & 66.49 & 0.517 & 16.67 & 3.69 & 0.08 & 1.25 & 3.39 & 3.99 & 3.77 & 0.154 & 100 \\
\hline CS07 & 69.76 & 0.383 & 15.66 & 2.76 & 0.074 & 0.94 & 3.04 & 4.15 & 3.13 & 0.109 & 100 \\
\hline CS09 & 71.87 & 0.32 & 14.94 & 2.1 & 0.054 & 0.58 & 1.94 & 3.69 & 4.39 & 0.101 & 100 \\
\hline CS10 & 68.07 & 0.443 & 15.99 & 3.13 & 0.061 & 1.21 & 3.29 & 3.84 & 3.82 & 0.15 & 100 \\
\hline CS12 & 63.69 & 0.638 & 17.39 & 4.28 & 0.069 & 1.79 & 4.03 & 4.07 & 3.81 & 0.229 & 100 \\
\hline CS13 & 67.99 & 0.508 & 16.21 & 3.2 & 0.056 & 1.03 & 3.66 & 3.59 & 3.61 & 0.148 & 100 \\
\hline CS15 & 59.36 & 0.956 & 17.92 & 6.66 & 0.138 & 2.86 & 6.09 & 3.73 & 2.09 & 0.194 & 100 \\
\hline CS16 & 66.87 & 0.474 & 16.3 & 3.61 & 0.07 & 1.5 & 3.76 & 3.38 & 3.93 & 0.105 & 100 \\
\hline CS19 & 54.79 & 1.064 & 18.03 & 8.44 & 0.125 & 4.45 & 6.77 & 3.38 & 2.66 & 0.296 & 100 \\
\hline $\mathrm{CS} 20 \mathrm{~b}$ & 56.83 & 0.9 & 19.59 & 6.73 & 0.127 & 2.56 & 5.58 & 4.46 & 2.82 & 0.411 & 100 \\
\hline $\mathrm{CS} 21$ & 65.67 & 0.557 & 16.3 & 4.16 & 0.081 & 1.76 & 4.13 & 3.42 & 3.79 & 0.123 & 100 \\
\hline $\mathrm{CS} 22$ & 65.23 & 0.622 & 16.22 & 4.56 & 0.085 & 1.95 & 4.37 & 3.31 & 3.51 & 0.139 & 100 \\
\hline CS23 & 64.6 & 0.584 & 16.69 & 4.55 & 0.084 & 1.92 & 4.81 & 3.61 & 3.02 & 0.137 & 100 \\
\hline $\mathrm{CS} 24$ & 65.49 & 0.573 & 16.19 & 4.44 & 0.085 & 1.89 & 4.09 & 3.26 & 3.85 & 0.132 & 100 \\
\hline CS25 & 65.74 & 0.634 & 15.87 & 4.61 & 0.084 & 1.95 & 3.96 & 3.39 & 3.58 & 0.189 & 100 \\
\hline CS26 & 64.49 & 0.716 & 16.34 & 5.1 & 0.093 & 2.09 & 4.63 & 3.53 & 2.83 & 0.175 & 100 \\
\hline $11 \mathrm{SN}-41$ & 62.3 & 0.86 & 16.19 & 6.31 & 0.1 & 2.58 & 4.53 & 3.22 & 3.41 & 0.22 & 100 \\
\hline $11 \mathrm{SN}-40$ & 70.48 & 0.38 & 15.87 & 2.3 & 0.04 & 0.78 & 2.24 & 3.21 & 4.36 & 0.09 & 100 \\
\hline $11 \mathrm{SN}-39$ & 66.9 & 0.61 & 15.7 & 4.2 & 0.07 & 1.51 & 3.75 & 3.55 & 3.3 & 0.17 & 100 \\
\hline
\end{tabular}


Normalized Major Elements Continued

\begin{tabular}{|c|c|c|c|c|c|c|c|c|c|c|c|}
\hline & $\mathrm{SiO} 2$ & $\mathrm{TiO} 2$ & $\mathrm{Al} 2 \mathrm{O} 3$ & $\mathrm{FeO}^{*}$ & $\mathrm{MnO}$ & $\mathrm{MgO}$ & $\mathrm{CaO}$ & $\mathrm{Na} 2 \mathrm{O}$ & $\mathrm{K} 2 \mathrm{O}$ & P2O5 & Total \\
\hline $11 \mathrm{SN}-38$ & 66.48 & 0.57 & 16.34 & 4.16 & 0.07 & 1.56 & 3.69 & 3.52 & 3.21 & 0.17 & 100 \\
\hline $11 \mathrm{SN}-37$ & 76.64 & 0.09 & 13.29 & 0.74 & 0.02 & 0.13 & 0.87 & 3.2 & 4.91 & 0.01 & 100 \\
\hline $11 \mathrm{SN}-36$ & 75.18 & 0.17 & 13.7 & 1.12 & 0.05 & 0.31 & 1.37 & 3.49 & 4.42 & 0.04 & 100 \\
\hline $11 \mathrm{SN}-35$ & 69.24 & 0.46 & 15.23 & 3.02 & 0.05 & 1.07 & 2.8 & 3.13 & 4.63 & 0.12 & 100 \\
\hline $11 \mathrm{SN}-34$ & 70.26 & 0.43 & 15.04 & 3 & 0.08 & 0.95 & 2.77 & 4.09 & 3.06 & 0.12 & 100 \\
\hline
\end{tabular}

Trace Elements

\begin{tabular}{|c|c|c|c|c|c|c|c|c|c|c|c|c|c|c|c|c|c|c|c|}
\hline & $\mathrm{Ni}$ & $\mathrm{Cr}$ & $\mathrm{Sc}$ & $\mathrm{V}$ & $\mathrm{Ba}$ & $\mathrm{Rb}$ & $\mathrm{Sr}$ & $\mathrm{Zr}$ & Y & $\mathrm{Nb}$ & $\mathrm{Ga}$ & $\mathrm{Cu}$ & $\mathrm{Zn}$ & $\mathrm{Pb}$ & $\mathrm{La}$ & $\mathrm{Ce}$ & Th & $\mathrm{Nd}$ & $\mathrm{U}$ \\
\hline CS01 & 21 & 55 & 20 & 143 & 640 & 139 & 331 & 162 & 24 & 10.2 & 18 & 5 & 287 & 51 & 34 & 47 & 6 & 28 & 3 \\
\hline $\mathrm{CS} 03$ & 27 & 42 & 19 & 196 & 351 & 219 & 405 & 148 & 11 & 13.4 & 29 & 44 & 189 & 13 & 30 & 51 & 7 & 21 & 6 \\
\hline CS05 & 6 & 9 & 13 & 112 & 919 & 92 & 459 & 172 & 21 & 8.4 & 19 & 19 & 80 & 13 & 24 & 50 & 7 & 21 & 2 \\
\hline CS06 & 3 & 6 & 7 & 59 & 1595 & 118 & 409 & 195 & 17 & 7.5 & 17 & 2 & 70 & 16 & 25 & 44 & 7 & 18 & 2 \\
\hline CS07 & 3 & 5 & 6 & 45 & 786 & 124 & 321 & 147 & 17 & 8 & 17 & 4 & 49 & 18 & 20 & 37 & 12 & 18 & 4 \\
\hline CS09 & 3 & 4 & 4 & 29 & 1215 & 194 & 391 & 184 & 10 & 11.7 & 19 & 4 & 60 & 25 & 42 & 72 & 24 & 26 & 4 \\
\hline CS10 & 3 & 7 & 6 & 63 & 1002 & 138 & 535 & 127 & 9 & 7.5 & 18 & 7 & 58 & 22 & 20 & 37 & 12 & 15 & 6 \\
\hline CS12 & 6 & 9 & 7 & 86 & 1025 & 135 & 674 & 157 & 9 & 8 & 20 & 13 & 81 & 19 & 30 & 49 & 11 & 19 & 3 \\
\hline CS13 & 2 & 4 & 5 & 51 & 1072 & 122 & 547 & 146 & 11 & 8.7 & 19 & 1 & 68 & 18 & 26 & 47 & 11 & 19 & 3 \\
\hline CS15 & 4 & 2 & 15 & 158 & 719 & 79 & 659 & 101 & 17 & 9.2 & 20 & 10 & 97 & 10 & 19 & 37 & 5 & 20 & 3 \\
\hline CS16 & 5 & 9 & 9 & 72 & 605 & 140 & 361 & 119 & 17 & 7.4 & 16 & 4 & 50 & 20 & 22 & 35 & 23 & 16 & 7 \\
\hline CS19 & 25 & 3 & 16 & 188 & 815 & 99 & 748 & 118 & 16 & 6 & 21 & 44 & 98 & 9 & 22 & 39 & 6 & 17 & 4 \\
\hline CS20b & 4 & 3 & 10 & 106 & 1039 & 105 & 792 & 248 & 26 & 12.4 & 22 & 9 & 104 & 11 & 34 & 69 & 10 & 33 & 4 \\
\hline $\mathrm{CS} 21$ & 5 & 10 & 10 & 85 & 751 & 155 & 374 & 122 & 16 & 7.9 & 17 & 27 & 59 & 21 & 15 & 33 & 26 & 14 & 9 \\
\hline $\mathrm{CS} 22$ & 5 & 10 & 11 & 97 & 830 & 135 & 396 & 133 & 18 & 8.3 & 16 & 12 & 61 & 17 & 19 & 36 & 16 & 15 & 6 \\
\hline
\end{tabular}


Trace Elements Continued

\begin{tabular}{|c|c|c|c|c|c|c|c|c|c|c|c|c|c|c|c|c|c|c|c|}
\hline & $\mathrm{Ni}$ & $\mathrm{Cr}$ & $\mathrm{Sc}$ & V & $\mathrm{Ba}$ & $\mathrm{Rb}$ & $\mathrm{Sr}$ & $\mathrm{Zr}$ & $\mathrm{Y}$ & $\mathrm{Nb}$ & $\mathrm{Ga}$ & $\mathrm{Cu}$ & $\mathrm{Zn}$ & $\mathrm{Pb}$ & $\mathrm{La}$ & $\mathrm{Ce}$ & Th & $\mathrm{Nd}$ & $\mathrm{U}$ \\
\hline $\mathrm{CS} 23$ & 5 & 11 & 11 & 96 & 691 & 119 & 427 & 128 & 19 & 8 & 17 & 10 & 61 & 18 & 16 & 34 & 15 & 16 & 6 \\
\hline $\mathrm{CS} 24$ & 4 & 10 & 10 & 89 & 835 & 152 & 376 & 136 & 18 & 7.4 & 17 & 9 & 63 & 21 & 15 & 30 & 26 & 17 & 5 \\
\hline $\mathrm{CS} 25$ & 8 & 12 & 8 & 85 & 837 & 150 & 463 & 160 & 15 & 9.6 & 18 & 9 & 76 & 18 & 22 & 45 & 22 & 22 & 7 \\
\hline CS26 & 5 & 11 & 9 & 101 & 721 & 150 & 464 & 160 & 17 & 9.9 & 19 & 10 & 75 & 16 & 19 & 37 & 20 & 20 & 8 \\
\hline $11 \mathrm{SN}-41$ & 13.7 & 17.3 & 14.4 & 119.8 & 960.1 & 128.5 & 475.2 & 202.9 & 21 & 13.3 & 19.4 & 12.5 & 100.3 & 12.1 & 32.2 & 76.7 & 15.9 & 23.4 & 4.6 \\
\hline $11 \mathrm{SN}-40$ & 3.5 & 7.2 & 2.8 & 35.6 & 939.9 & 151.1 & 386.6 & 140.1 & 13 & 11.6 & 18.6 & -1.9 & 50.2 & 16.2 & 34.7 & 68.1 & 21.2 & 13.1 & 5.1 \\
\hline $11 \mathrm{SN}-39$ & 5.4 & 6.6 & 9.4 & 73.1 & 892.9 & 118.8 & 478.9 & 149.4 & 14.2 & 12.8 & 18.1 & 6.4 & 71.8 & 13.8 & 33.4 & 69.1 & 21.8 & 18.1 & 5.7 \\
\hline $11 \mathrm{SN}-38$ & 10.2 & 13 & 10.1 & 75.9 & 855.2 & 105.5 & 494.9 & 138.4 & 10.8 & 9.5 & 18.3 & 11.3 & 71.5 & 11.9 & 27.9 & 54.1 & 14.1 & 12.2 & 3.4 \\
\hline $11 \mathrm{SN}-37$ & 4.8 & 7.2 & 6.8 & 14.4 & 185.9 & 207.6 & 105.1 & 70.8 & 4.8 & 5.9 & 15.7 & 0.7 & 14.2 & 32.2 & 28 & 40.4 & 29.6 & 0.5 & 8.8 \\
\hline $11 \mathrm{SN}-36$ & -0.5 & 7.9 & 1.7 & 16.7 & 646.5 & 192.2 & 215.5 & 82.4 & 9.1 & 9.1 & 16.1 & -1.9 & 32.2 & 23.5 & 23.8 & 46.3 & 17.8 & 14.1 & 3.2 \\
\hline $11 \mathrm{SN}-35$ & 9.4 & 4.7 & 6.7 & 50.5 & 106 & 177.6 & 402.9 & 134 & 15.2 & 12.6 & 16.8 & 3.5 & 65.3 & 22.6 & 29.4 & 56.2 & 24.6 & 20 & 4.9 \\
\hline $11 \mathrm{SN}-34$ & 7.8 & 6.5 & 5.2 & 39 & 772.8 & 117.4 & 286.2 & 159.8 & 24 & 12 & 17.5 & -0.6 & 55.1 & 12.4 & 41.2 & 76.7 & 16.8 & 19.7 & 4.9 \\
\hline
\end{tabular}




\section{APPENDIX E: SHRIMP Trace Element in Zircon Data}

Highlighted analyses were not included in results because they are likely inclusions.

\begin{tabular}{|c|c|c|c|c|c|c|c|c|c|c|c|}
\hline & $\mathbf{L i}$ & Be & B & $\mathbf{F}$ & $\mathbf{N a}$ & Al & $\mathbf{P}$ & $\mathbf{K}$ & Ca & Sc & $48 \mathrm{Ti}$ \\
\hline CS01-1.1 & 1.75 & 0.27 & 1.71 & 154.22 & 8.00 & 74.82 & 629.73 & 13.76 & 27.66 & 284.05 & 45.14 \\
\hline CS01-1.2 & 0.44 & 0.30 & 2.37 & 83.08 & 3.33 & 28.34 & 338.99 & 1.22 & 5.35 & 154.85 & 55.18 \\
\hline CS01-2.1 & 0.76 & 0.06 & 0.52 & 66.07 & 6.20 & 22.79 & 402.28 & 1.70 & 7.45 & 140.87 & 19.22 \\
\hline CS01-2.2 & 2.90 & 0.14 & 5.32 & 71.07 & 9.13 & 53.24 & 519.06 & 126.84 & 19.33 & 139.93 & 121.93 \\
\hline CS01-3.1 & 0.50 & 0.17 & 1.23 & 37.09 & 2.19 & 17.34 & 567.33 & 0.92 & 3.76 & 108.89 & 24.40 \\
\hline CS01-3.2 & 3.46 & 0.62 & 3.85 & 79.87 & 4.06 & 30.47 & 1476.93 & 1.15 & 7.64 & 225.80 & 31.26 \\
\hline CS01-4.1 & 1.85 & 0.12 & 2.08 & 49.85 & 5.76 & 23.33 & 1066.63 & 1.31 & 5.50 & 281.11 & 38.27 \\
\hline CS01-4.2 & 1.83 & 0.15 & 0.78 & 50.15 & 4.89 & 23.93 & 850.15 & 1.31 & 4.46 & 200.90 & 38.40 \\
\hline CS01-5.1 & 0.86 & 0.23 & 2.26 & 49.92 & 5.32 & 21.38 & 515.86 & 1.37 & 4.85 & 78.16 & 26.60 \\
\hline CS01-5.2 & 0.58 & 0.12 & 2.64 & 159.29 & 6.19 & 37.13 & 557.81 & 1.40 & 11.41 & 75.74 & 31.79 \\
\hline CS01-6.1 & 0.19 & 0.03 & 2.64 & 98.55 & 5.50 & 21.45 & 374.40 & 1.09 & 5.07 & 153.15 & 40.66 \\
\hline CS01-7.1 & 2.79 & 0.89 & 44.32 & 956.37 & 23.20 & 2295.48 & 700.94 & 62.57 & 111.67 & 99.83 & 219.14 \\
\hline CS01-8.1 & 0.67 & 0.33 & 1.83 & 60.94 & 3.81 & 21.29 & 786.22 & 1.32 & 5.51 & 229.03 & 33.12 \\
\hline CS01-8.2 & 1.14 & 0.09 & 3.52 & 65.73 & 3.80 & 25.58 & 610.31 & 1.57 & 5.94 & 145.98 & 43.33 \\
\hline CS01-9.1 & 3.09 & 0.26 & 3.13 & 143.33 & 2.39 & 52.36 & 76.90 & 1.07 & 8.20 & 116.24 & 50.76 \\
\hline CS01-10.1 & 1.15 & 0.06 & 10.21 & 55.63 & 4.68 & 698.13 & 469.49 & 1.02 & 3.28 & 134.92 & 22.52 \\
\hline CS01-10.2 & 0.51 & 0.09 & 12.29 & 85.42 & 10.45 & 29.88 & 649.47 & 3.07 & 10.69 & 325.87 & 59.28 \\
\hline CS01-11.1 & 0.73 & 0.16 & 7.50 & 77.88 & 6.73 & 26.29 & 562.97 & 1.41 & 6.05 & 139.37 & 53.53 \\
\hline CS03-1.1 & 1.70 & 0.03 & 3.83 & 13163.65 & 10.58 & 26.52 & 8711.81 & 1.74 & 8558.10 & 34.61 & 22.76 \\
\hline CS03-1.2 & 0.08 & 0.00 & 2.24 & 31.04 & 2.47 & 21.82 & 202.57 & 1.02 & 4.48 & 44.88 & 19.27 \\
\hline CS03-2.1 & 0.50 & 0.03 & 3.24 & 77.18 & 2.74 & 21.64 & 171.52 & 1.22 & 5.33 & 50.31 & 20.11 \\
\hline CS03-2.2 & 1.25 & 0.25 & 5.16 & 65.25 & 2.86 & 173.64 & 166.04 & 1.43 & 8.70 & 93.30 & 37.65 \\
\hline CS03-3.1 & 0.65 & 0.09 & 1.68 & 51.05 & 5.67 & 23.24 & 349.82 & 2.13 & 5.01 & 87.18 & 30.82 \\
\hline CS03-4.1 & 1.48 & 0.00 & 4.58 & 36.32 & 3.06 & 22.11 & 82.82 & 1.87 & 6.35 & 34.34 & 25.78 \\
\hline CS03-4.2 & 0.25 & 0.16 & 1.84 & 29.13 & 2.79 & 20.29 & 313.00 & 1.16 & 5.94 & 102.71 & 32.79 \\
\hline CS03-6.1 & 0.13 & 0.03 & 1.48 & 43.87 & 3.38 & 22.65 & 326.56 & 1.73 & 7.91 & 75.07 & 45.50 \\
\hline CS03-6.2 & 0.33 & 0.00 & 2.98 & 47.77 & 3.84 & 23.23 & 255.97 & 1.82 & 9.79 & 57.72 & 43.08 \\
\hline
\end{tabular}




\begin{tabular}{|c|c|c|c|c|c|c|c|c|c|c|c|}
\hline & $\mathbf{L i}$ & Be & B & $\mathbf{F}$ & $\mathrm{Na}$ & Al & $\mathbf{P}$ & $\mathbf{K}$ & $\mathbf{C a}$ & Sc & $48 \mathrm{Ti}$ \\
\hline CS03-8.1 & 0.46 & 0.03 & 1.84 & 53.02 & 2.75 & 19.54 & 152.92 & 1.30 & 13.26 & 34.52 & 22.78 \\
\hline CS03-8.2 & 1.63 & 0.03 & 2.12 & 77.15 & 3.36 & 21.75 & 218.57 & 1.40 & 11.46 & 52.37 & 25.93 \\
\hline CS03-8.3 & 0.33 & 0.08 & 8.94 & 64.99 & 2.67 & 370.93 & 203.65 & 2.01 & 11.92 & 59.17 & 32.94 \\
\hline CS03-9.1 & 2.93 & 0.58 & 179.77 & 54.52 & 1460.81 & 23701.18 & 21.31 & 9207.60 & 250.62 & 4.08 & 8.25 \\
\hline CS03-9.2 & 1.08 & 0.03 & 13.64 & 40.01 & 11.13 & 24.69 & 136.93 & 3.58 & 16.10 & 42.22 & 22.39 \\
\hline CS03-10.1 & 1.06 & 0.10 & 3.64 & 43.68 & 2.77 & 82.94 & 335.98 & 1.23 & 11.79 & 68.74 & 37.97 \\
\hline CSO3-10.2 & 0.83 & 0.10 & 3.04 & 46.08 & 2.80 & 22.17 & 171.61 & 1.23 & 12.28 & 47.54 & 32.07 \\
\hline CS03-11.1 & 1.25 & 0.03 & 8.40 & 63.62 & 5.05 & 1113.77 & 318.23 & 6.22 & 8.50 & 46.44 & 44.03 \\
\hline CS03-11.2 & 2.25 & 0.05 & 2.31 & 41.29 & 3.26 & 19.49 & 343.27 & 1.01 & 6.66 & 61.73 & 24.63 \\
\hline CS07-1.1 & 0.53 & 0.01 & 1.90 & 8.11 & 1.30 & 10.76 & 587.30 & 0.80 & 2.25 & 167.61 & 31.76 \\
\hline CS07-1.2 & 0.24 & 0.02 & 0.33 & 7.95 & 1.22 & 17.42 & 353.78 & 0.69 & 2.26 & 52.40 & 21.83 \\
\hline CS07-1.3 & 0.73 & 0.08 & 1.55 & 22.25 & 1.60 & 13.27 & 409.10 & 1.07 & 2.71 & 69.68 & 23.76 \\
\hline CS07-2.1 & 0.58 & 0.08 & 0.67 & 3.49 & 1.36 & 11.79 & 676.93 & 0.68 & 2.01 & 126.94 & 15.82 \\
\hline CS07-2.2 & 5.05 & 0.14 & 1.13 & 9.41 & 1.46 & 14.06 & 592.91 & 0.81 & 2.12 & 100.73 & 9.98 \\
\hline CS07-3.1 & 1.27 & 0.04 & 1.32 & 9.53 & 1.31 & 19.50 & 590.63 & 0.74 & 2.30 & 104.34 & 29.86 \\
\hline CS07-3.2 & 0.61 & 0.01 & 1.87 & 11.08 & 1.28 & 20.68 & 584.26 & 0.68 & 2.12 & 136.08 & 43.24 \\
\hline CS07-4.1 & 2.60 & 0.04 & 0.76 & 5.63 & 2.10 & 11.29 & 161.13 & 0.80 & 2.47 & 16.31 & 9.02 \\
\hline CS07-4.2 & 0.19 & 0.00 & 1.00 & 21.84 & 1.41 & 12.79 & 344.57 & 0.79 & 2.35 & 76.93 & 33.79 \\
\hline CS07-4.3 & 3.63 & 0.08 & 1.49 & 13.92 & 1.43 & 13.01 & 284.73 & 1.02 & 3.39 & 36.70 & 16.98 \\
\hline CS07-5.1 & 0.28 & 0.00 & 0.82 & 15.86 & 1.20 & 9.92 & 332.60 & 0.48 & 1.67 & 89.25 & 30.13 \\
\hline CS07-5.2 & 0.33 & 0.00 & 0.74 & 12.26 & 1.37 & 11.49 & 341.45 & 0.67 & 2.45 & 99.90 & 34.34 \\
\hline CS07-6.1 & 0.39 & 0.12 & 1.22 & 6.83 & 1.38 & 11.88 & 573.69 & 0.63 & 4.15 & 109.81 & 14.02 \\
\hline CS07-6.2 & 0.57 & 0.01 & 0.74 & 4.41 & 1.13 & 40.73 & 1112.30 & 0.50 & 1.76 & 381.42 & 33.87 \\
\hline CS07-6.3 & 0.23 & 0.07 & 0.76 & 14.67 & 1.09 & 9.07 & 483.42 & 0.58 & 1.88 & 113.34 & 31.77 \\
\hline CS07-7.1 & 1.24 & 0.06 & 1.08 & 9.51 & 1.41 & 10.65 & 445.74 & 0.68 & 2.18 & 53.13 & 20.29 \\
\hline CS07-7.2 & 0.77 & 0.25 & 11.12 & 18.43 & 17.22 & 158.41 & 667.15 & 66.43 & 3.65 & 184.86 & 43.08 \\
\hline CS10-1.1 & 1.64 & 0.00 & 1.99 & 37.37 & 2.70 & 19.68 & 251.97 & 1.31 & 4.67 & 90.68 & 19.07 \\
\hline CS10-1.2 & 1.14 & 0.05 & 1.98 & 25.46 & 2.81 & 22.25 & 270.61 & 1.28 & 4.41 & 97.52 & 26.63 \\
\hline CS10-2.1 & 0.82 & 0.05 & 2.68 & 66.94 & 2.34 & 19.65 & 285.09 & 1.21 & 5.60 & 87.11 & 33.84 \\
\hline CS10-2.2 & 0.80 & 0.00 & 1.83 & 20.23 & 2.09 & 20.04 & 237.59 & 1.06 & 4.81 & 77.23 & 28.78 \\
\hline
\end{tabular}




\begin{tabular}{|c|c|c|c|c|c|c|c|c|c|c|c|}
\hline & $\mathbf{L i}$ & Be & B & $\mathbf{F}$ & $\mathrm{Na}$ & Al & $\mathbf{P}$ & $\mathbf{K}$ & $\mathbf{C a}$ & Sc & $48 \mathrm{Ti}$ \\
\hline CS10-3.1 & 2.76 & 0.22 & 2.43 & 51.64 & 2.13 & 20.22 & 147.01 & 1.20 & 15.00 & 120.33 & 17.74 \\
\hline CS10-3.2 & 0.67 & 0.05 & 3.30 & 68.53 & 2.44 & 18.85 & 121.19 & 1.28 & 4.05 & 75.99 & 18.75 \\
\hline CS10-3.3 & 0.93 & 0.02 & 1.49 & 49.09 & 2.60 & 17.00 & 152.55 & 1.32 & 5.39 & 70.26 & 16.07 \\
\hline CS10-4.1 & 1.46 & 0.17 & 2.53 & 40.78 & 2.37 & 237.47 & 2043.74 & 1.77 & 7.29 & 539.34 & 44.82 \\
\hline CS10-4.2 & 2.89 & 0.09 & 1.65 & 36.81 & 2.67 & 45.46 & 54.99 & 1.09 & 4.69 & 96.78 & 17.80 \\
\hline CS10-5.1 & 1.12 & 0.13 & 3.43 & 54.71 & 2.87 & 22.95 & 91.07 & 1.66 & 4.45 & 106.58 & 18.95 \\
\hline CS10-5.2 & 1.47 & 0.07 & 1.78 & 20.85 & 1.53 & 17.20 & 173.22 & 1.03 & 2.94 & 60.70 & 21.57 \\
\hline CS10-7.1 & 1.87 & 0.07 & 1.21 & 32.68 & 7.36 & 16.35 & 141.22 & 1.25 & 8.67 & 79.21 & 22.30 \\
\hline CS10-7.2 & 0.73 & 0.17 & 2.53 & 29.50 & 3.61 & 17.89 & 175.45 & 1.05 & 4.48 & 107.50 & 27.68 \\
\hline CS10-8.1 & 0.77 & 0.10 & 2.96 & 45.06 & 3.62 & 20.28 & 577.90 & 1.55 & 4.59 & 205.70 & 62.83 \\
\hline CS10-8.2 & 1.94 & 0.07 & 4.74 & 41.00 & 4.71 & 590.48 & 148.74 & 5.32 & 26.49 & 24.59 & 34.86 \\
\hline CS10-10.1 & 0.49 & 0.06 & 1.24 & 40.58 & 2.66 & 18.07 & 217.86 & 1.45 & 5.64 & 80.10 & 23.32 \\
\hline CS10-10.2 & 2.32 & 0.13 & 3.34 & 46.97 & 2.81 & 19.64 & 215.23 & 1.53 & 6.16 & 55.11 & 23.58 \\
\hline CS13-1.1 & 0.22 & 0.00 & 3.19 & 29.80 & 2.40 & 19.88 & 394.27 & 1.13 & 4.51 & 52.20 & 21.16 \\
\hline CS13-1.2 & 1.52 & 0.07 & 4.09 & 70.78 & 2.75 & 22.35 & 335.95 & 1.69 & 8.36 & 78.32 & 26.55 \\
\hline CS13-2.1 & 0.71 & 0.02 & 1.26 & 27.12 & 2.12 & 15.37 & 515.71 & 1.36 & 4.35 & 138.69 & 29.38 \\
\hline CS13-2.2 & 0.70 & 0.04 & 1.77 & 67.54 & 2.91 & 14.03 & 477.69 & 1.37 & 4.88 & 159.90 & 35.64 \\
\hline CS13-3.1 & 1.31 & 0.17 & 2.30 & 32.52 & 14.14 & 25.61 & 444.13 & 3.91 & 14.97 & 104.92 & 34.96 \\
\hline CS13-4.1 & 0.30 & 0.00 & 17.41 & 42.60 & 4.75 & 25.56 & 302.71 & 1.42 & 6.61 & 108.40 & 35.07 \\
\hline CS13-4.2 & 0.26 & 0.00 & 1.79 & 50.59 & 4.62 & 15.85 & 283.89 & 1.46 & 4.36 & 92.27 & 26.96 \\
\hline CS13-5.1 & 1.15 & 0.04 & 2.86 & 66.35 & 3.24 & 23.67 & 239.67 & 1.88 & 5.53 & 75.71 & 25.67 \\
\hline CS13-5.2 & 0.70 & 0.09 & 3.76 & 274.28 & 2.59 & 18.17 & 343.47 & 0.99 & 27.95 & 89.51 & 23.23 \\
\hline CS13-5.3 & 0.90 & 0.07 & 3.12 & 65.76 & 2.76 & 17.03 & 234.58 & 0.88 & 5.32 & 57.20 & 24.33 \\
\hline CS13-6.1 & 1.20 & 0.06 & 8.60 & 32.37 & 18.65 & 154.77 & 216.44 & 47.79 & 10.36 & 31.76 & 22.62 \\
\hline CS13-6.2 & 2.85 & 0.04 & 3.19 & 33.54 & 2.72 & 18.66 & 690.69 & 1.23 & 4.02 & 43.67 & 25.24 \\
\hline CS13-7.1 & 0.23 & 0.04 & 3.22 & 34.45 & 3.83 & 17.31 & 248.21 & 2.13 & 6.07 & 66.37 & 30.76 \\
\hline CS13-7.2 & 1.94 & 0.12 & 2.33 & 40.80 & 3.07 & 22.35 & 170.02 & 1.63 & 5.59 & 36.67 & 23.26 \\
\hline CS13-9.1 & 0.44 & 0.00 & 1.36 & 20.88 & 2.04 & 19.74 & 192.53 & 0.96 & 4.62 & 44.04 & 20.69 \\
\hline CS13-9.2 & 1.75 & 0.04 & 3.98 & 50.11 & 1.88 & 24.49 & 134.77 & 0.71 & 5.52 & 54.67 & 33.69 \\
\hline CS19-1.1 & 0.47 & 0.08 & 1.59 & 33.39 & 1.79 & 118.37 & 197.09 & 1.39 & 3.81 & 62.61 & 19.56 \\
\hline
\end{tabular}




\begin{tabular}{|c|c|c|c|c|c|c|c|c|c|c|c|}
\hline & $\mathbf{L i}$ & Be & B & $\mathbf{F}$ & $\mathbf{N a}$ & Al & $\mathbf{P}$ & $\mathbf{K}$ & $\mathbf{C a}$ & Sc & $48 \mathrm{Ti}$ \\
\hline CS19-2.1 & 0.24 & 0.02 & 2.85 & 13.06 & 2.50 & 16.78 & 238.76 & 0.90 & 6.36 & 63.30 & 20.52 \\
\hline CS19-2.2 & 1.10 & 0.14 & 4.60 & 52.39 & 3.19 & 20.91 & 260.25 & 1.70 & 7.02 & 85.16 & 28.82 \\
\hline CS19-3.1 & 0.30 & 0.00 & 2.17 & 51.56 & 1.80 & 78.89 & 120.44 & 6.23 & 10.17 & 36.70 & 24.23 \\
\hline CS19-3.2 & 0.40 & 0.04 & 1.16 & 34.44 & 1.71 & 15.40 & 223.18 & 0.81 & 3.66 & 40.65 & 14.01 \\
\hline CS19-4.1 & 0.64 & 0.06 & 2.09 & 29.63 & 1.82 & 20.66 & 117.78 & 0.74 & 4.08 & 27.07 & 16.32 \\
\hline CS19-4.2 & 1.51 & 0.20 & 1.95 & 73.97 & 2.22 & 24.40 & 1241.37 & 1.11 & 6.43 & 262.29 & 46.76 \\
\hline CS19-5.1 & 2.27 & 0.55 & 101.27 & 49.76 & 2478.11 & 10989.48 & 361.18 & 571.11 & 522.20 & 67.05 & 40.77 \\
\hline CS19-5.2 & 3.21 & 2.28 & 289.79 & 1368.72 & 79.04 & 7376.17 & 3331.47 & 218.30 & 1001.19 & 183.04 & 1139.21 \\
\hline CS19-6.1 & 0.78 & 0.07 & 3.77 & 22.13 & 2.55 & 18.11 & 529.63 & 0.95 & 4.50 & 190.28 & 27.63 \\
\hline CS19-6.2 & 10.94 & 0.40 & 36.24 & 145.95 & 6.97 & 976.60 & 777.84 & 12.73 & 12.44 & 236.88 & 46.65 \\
\hline CS19-7.1 & 1.32 & 0.13 & 6.38 & 35.91 & 2.79 & 41.68 & 185.59 & 2.19 & 14.23 & 45.89 & 25.91 \\
\hline CS19-7.2 & 3.34 & 0.26 & 15.36 & 163.51 & 17.37 & 1246.63 & 184.71 & 28.91 & 103.97 & 57.43 & 74.15 \\
\hline CS25-1.1 & 0.81 & 0.02 & 4.57 & 95.82 & 2.21 & 19.35 & 292.71 & 1.14 & 10.18 & 63.28 & 22.95 \\
\hline CS25-1.2 & 1.94 & 0.06 & 1.65 & 48.62 & 2.32 & 18.08 & 254.92 & 1.07 & 6.26 & 53.26 & 23.99 \\
\hline CS25-2.1 & 1.02 & 0.13 & 3.20 & 21.60 & 3.38 & 23.81 & 376.24 & 1.34 & 3.82 & 97.44 & 21.07 \\
\hline CS25-2.2 & 0.44 & 0.02 & 24.73 & 87.50 & 2.42 & 17.91 & 314.61 & 1.08 & 7.08 & 78.95 & 28.99 \\
\hline CS25-3.1 & 0.20 & 0.07 & 6.20 & 108.60 & 3.32 & 46.56 & 386.93 & 1.15 & 13.01 & 92.13 & 33.75 \\
\hline CS25-3.2 & 0.96 & 0.02 & 6.03 & 28.38 & 5.61 & 25.73 & 223.03 & 1.78 & 16.20 & 41.21 & 35.88 \\
\hline CS25-4.1 & 0.44 & 0.02 & 1.75 & 29.99 & 1.93 & 16.44 & 212.15 & 0.89 & 4.10 & 60.91 & 26.96 \\
\hline CS25-4.2 & 2.42 & 0.09 & 2.45 & 25.59 & 1.67 & 17.98 & 619.69 & 0.84 & 3.43 & 112.08 & 28.61 \\
\hline CS25-4.3 & 1.66 & 0.04 & 2.10 & 28.81 & 1.53 & 50.39 & 176.81 & 1.20 & 3.60 & 61.26 & 28.47 \\
\hline CS25-6.1 & 3.47 & 0.09 & 3.21 & 52.43 & 2.56 & 17.48 & 363.13 & 1.97 & 5.78 & 70.66 & 33.02 \\
\hline CS25-6.2 & 4.20 & 0.35 & 19.24 & 146621.15 & 15.83 & 539.42 & 94769.77 & 15.87 & 54274.41 & 65.88 & 85.61 \\
\hline CS25-7.1 & 0.42 & 0.05 & 4.63 & 39.12 & 3.27 & 172.57 & 354.29 & 2.83 & 6.37 & 75.52 & 35.60 \\
\hline CS25-7.2 & 6.98 & 0.65 & 15.37 & 167.23 & 15.86 & 1313.12 & 429.15 & 14.98 & 12.39 & 83.42 & 133.50 \\
\hline CS25-8.1 & 1.66 & 0.22 & 1.42 & 38.22 & 1.94 & 16.61 & 259.74 & 1.00 & 4.57 & 53.10 & 27.42 \\
\hline CS25-8.2 & 3.40 & 0.07 & 5.41 & 49.59 & 2.43 & 23.78 & 650.26 & 1.25 & 5.54 & 81.24 & 34.23 \\
\hline CS25-8.3 & 2.04 & 0.15 & 6.39 & 45.15 & 2.31 & 162.14 & 266.82 & 2.70 & 7.18 & 59.65 & 34.63 \\
\hline 11SN34-1.1 & 0.34 & 0.12 & 1.53 & 97.00 & 6.91 & 19.17 & 381.74 & 5.27 & 2.50 & 84.45 & 26.06 \\
\hline 11SN34-1.2 & 0.61 & 0.16 & 1.42 & 87.55 & 6.64 & 12.76 & 434.89 & 4.83 & 2.63 & 114.11 & 15.51 \\
\hline
\end{tabular}




\begin{tabular}{|c|c|c|c|c|c|c|c|c|c|c|c|}
\hline & $\mathbf{L i}$ & $\mathbf{B e}$ & B & $\mathbf{F}$ & $\mathbf{N a}$ & Al & $\mathbf{P}$ & $\mathbf{K}$ & $\mathbf{C a}$ & Sc & $48 \mathrm{Ti}$ \\
\hline 11SN34-2.1 & 0.07 & 0.04 & 2.08 & 69.30 & 1.76 & 17.10 & 208.73 & 2.01 & 3.15 & 57.11 & 31.18 \\
\hline $11 \mathrm{SN} 34-2.2$ & 0.42 & 0.13 & 0.74 & 39.93 & 1.85 & 15.16 & 403.96 & 1.56 & 3.33 & 95.51 & 12.86 \\
\hline $11 \mathrm{SN} 34-3.1$ & 6.03 & 4.39 & 101.52 & 1766.81 & 6.38 & 490.68 & 1458.63 & 11.71 & 350.47 & 164.61 & 183.75 \\
\hline 11SN34-3.2 & 3.54 & 0.13 & 1.48 & 53.00 & 1.45 & 15.60 & 104.30 & 1.35 & 3.85 & 23.10 & 10.69 \\
\hline 11 SN34-4.1 & 0.19 & 0.14 & 1.89 & 94.72 & 1.84 & 16.81 & 631.73 & 1.45 & 3.74 & 172.09 & 21.73 \\
\hline 11SN34-4.2 & 0.33 & 0.14 & 2.18 & 44.37 & 1.79 & 133.32 & 525.43 & 2.11 & 5.28 & 197.60 & 38.41 \\
\hline $11 \mathrm{SN} 34-5.1$ & 0.53 & 0.10 & 1.36 & 69.89 & 1.89 & 18.51 & 350.81 & 1.48 & 5.31 & 84.76 & 29.52 \\
\hline 11SN34-5.2 & 0.78 & 0.15 & 2.31 & 36.69 & 1.94 & 17.53 & 467.74 & 1.48 & 3.70 & 133.72 & 18.92 \\
\hline 11SN34-6.1 & 1.87 & 0.12 & 9.05 & 18.21 & 262.67 & 25494.69 & 85.53 & 16980.83 & 5.26 & 13.31 & 20.41 \\
\hline 11 SN34-6.2 & 2.62 & 0.07 & 2.10 & 413.85 & 1.83 & 30.50 & 1150.90 & 1.35 & 427.79 & 90.10 & 24.57 \\
\hline $11 \mathrm{SN} 34-6.3$ & 5.70 & 2.56 & 38.77 & 250.11 & 3.04 & 238.07 & 992.53 & 2.44 & 92.71 & 128.84 & 118.46 \\
\hline 11SN34-7.1 & 0.76 & 0.27 & 2.16 & 77.94 & 3.03 & 48.10 & 425.61 & 5.64 & 5.97 & 99.89 & 18.06 \\
\hline 11SN34-7.2 & 1.74 & 0.15 & 2.14 & 17.73 & 1.69 & 23.90 & 694.50 & 1.15 & 3.32 & 122.50 & 23.53 \\
\hline $11 \mathrm{SN} 34-8.1$ & 0.45 & 0.10 & 1.90 & 53.09 & 6.42 & 15.75 & 197.34 & 5.00 & 3.96 & 43.54 & 17.38 \\
\hline $11 \mathrm{SN} 34-8.2$ & 2.15 & 0.20 & 2.17 & 43.51 & 5.37 & 13.37 & 816.53 & 5.31 & 3.90 & 106.17 & 19.57 \\
\hline 11SN35-1.1 & 2.59 & 0.28 & 1.58 & 34.12 & 1.43 & 13.12 & 187.74 & 1.16 & 2.85 & 40.95 & 8.46 \\
\hline $11 \mathrm{SN} 35-1.2$ & 1.19 & 0.09 & 3.99 & 47.52 & 2.16 & 230.80 & 281.86 & 19.19 & 7.38 & 57.08 & 58.51 \\
\hline $11 \mathrm{SN} 35-2.1$ & 1.59 & 0.01 & 1.29 & 9.66 & 1.15 & 13.10 & 196.82 & 0.97 & 2.80 & 45.01 & 19.98 \\
\hline $11 \mathrm{SN} 35-2.2$ & 0.45 & 0.05 & 1.21 & 35.33 & 1.29 & 14.08 & 351.60 & 1.14 & 2.76 & 86.70 & 26.16 \\
\hline $11 \mathrm{SN} 35-3.1$ & 2.93 & 0.12 & 0.98 & 8.94 & 1.34 & 12.90 & 227.44 & 1.13 & 3.00 & 48.77 & 14.85 \\
\hline $11 \mathrm{SN} 35-3.2$ & 1.02 & 0.29 & 3.83 & 31.64 & 15.92 & 75.53 & 2731.89 & 14.76 & 2646.41 & 101.42 & 26.40 \\
\hline 11SN35-4.1 & 3.73 & 0.11 & 0.75 & 11.07 & 4.03 & 12.15 & 255.50 & 3.23 & 2.79 & 48.08 & 14.98 \\
\hline $11 \mathrm{SN} 35-4.2$ & 0.18 & 0.03 & 0.49 & 25.68 & 5.54 & 12.44 & 645.33 & 3.40 & 2.55 & 111.01 & 43.32 \\
\hline 11SN35-5.1 & 0.59 & 0.06 & 1.00 & 10.13 & 2.99 & 14.94 & 428.14 & 2.49 & 2.78 & 138.70 & 20.83 \\
\hline $11 \mathrm{SN} 35-5.2$ & 1.27 & 0.19 & 2.17 & 36.02 & 3.10 & 14.89 & 232.05 & 2.64 & 5.62 & 152.59 & 15.15 \\
\hline $11 \mathrm{SN} 35-6.1$ & 1.90 & 0.08 & 1.24 & 8.60 & 1.21 & 10.91 & 313.31 & 0.66 & 2.48 & 54.72 & 21.39 \\
\hline $11 \mathrm{SN} 35-6.2$ & 1.52 & 0.14 & 2.76 & 517.61 & 7.37 & 78.08 & 954.73 & 27.43 & 511.83 & 69.57 & 23.84 \\
\hline 11SN35-7.1 & 3.59 & 0.04 & 2.86 & 13.99 & 1.36 & 14.74 & 329.92 & 0.81 & 3.13 & 60.24 & 24.71 \\
\hline $11 \mathrm{SN} 35-7.2$ & 1.48 & 0.08 & 4.35 & 266.27 & 2.32 & 14.97 & 409.95 & 0.73 & 6.88 & 84.33 & 19.99 \\
\hline 11 SN35-8.1 & 1.70 & 0.04 & 1.14 & 6.58 & 1.41 & 13.38 & 317.37 & 0.75 & 2.47 & 57.64 & 20.16 \\
\hline $11 \mathrm{SN} 35-8.2$ & 1.87 & 0.07 & 1.85 & 3.71 & 1.50 & 12.71 & 224.29 & 0.67 & 2.61 & 60.64 & 19.75 \\
\hline
\end{tabular}




\begin{tabular}{|c|c|c|c|c|c|c|c|c|c|c|c|}
\hline & $\mathbf{L i}$ & $\mathbf{B e}$ & B & $\mathbf{F}$ & $\mathbf{N a}$ & Al & $\mathbf{P}$ & $\mathbf{K}$ & $\mathbf{C a}$ & Sc & $48 \mathrm{Ti}$ \\
\hline $11 \mathrm{SN} 35-8.3$ & 1.05 & 0.11 & 1.06 & 3.11 & 1.62 & 12.96 & 354.76 & 0.79 & 2.85 & 76.76 & 28.10 \\
\hline 11SN36-1.1 & 1.30 & 0.05 & 0.92 & 1.79 & 1.02 & 10.66 & 155.28 & 0.76 & 2.16 & 85.67 & 13.21 \\
\hline 11SN36-1.2 & 7.28 & 0.29 & 1.23 & 4.95 & 1.53 & 12.96 & 151.68 & 0.93 & 2.40 & 122.85 & 17.43 \\
\hline $11 \mathrm{SN} 36-2.1$ & 3.63 & 0.11 & 1.31 & 11.75 & 1.24 & 12.59 & 288.58 & 0.86 & 2.22 & 58.98 & 20.92 \\
\hline $11 \mathrm{SN} 36-2.2$ & 1.94 & 0.03 & 1.60 & 13.87 & 1.19 & 13.66 & 288.42 & 0.86 & 2.20 & 89.68 & 17.05 \\
\hline $11 \mathrm{SN} 36-3.1$ & 1.43 & 0.11 & 0.95 & 6.83 & 1.32 & 13.60 & 102.77 & 0.89 & 2.30 & 60.40 & 11.77 \\
\hline $11 \mathrm{SN} 36-3.2$ & 5.17 & 0.50 & 2.70 & 18.28 & 1.65 & 14.16 & 170.48 & 1.00 & 2.92 & 169.38 & 16.20 \\
\hline 11SN36-4.1 & 0.29 & 0.07 & 0.91 & 9.42 & 1.36 & 19.30 & 456.38 & 0.86 & 2.67 & 158.45 & 17.92 \\
\hline 11 SN36-4.2 & 0.42 & 0.83 & 7.08 & 111.61 & 7.08 & 153.73 & 545.74 & 15.64 & 110.71 & 227.37 & 27.86 \\
\hline 11SN36-5.1 & 1.96 & 0.09 & 2.48 & 13.00 & 2.60 & 13.62 & 274.39 & 2.41 & 4.52 & 59.89 & 18.98 \\
\hline $11 \mathrm{SN} 36-5.2$ & 1.62 & 0.18 & 2.08 & 17.52 & 1.63 & 13.79 & 362.29 & 1.01 & 3.98 & 93.77 & 21.04 \\
\hline $11 \mathrm{SN} 36-6.1$ & 1.57 & 0.36 & 4.72 & 16.75 & 2.10 & 14.38 & 182.87 & 1.78 & 5.30 & 108.40 & 49.53 \\
\hline $11 \mathrm{SN} 36-6.2$ & 0.28 & 0.43 & 10.01 & 25.66 & 2.85 & 541.63 & 271.66 & 2.29 & 11.12 & 78.75 & 45.15 \\
\hline 11SN36-7.1 & 0.16 & 0.04 & 0.83 & 20.86 & 1.52 & 12.78 & 268.92 & 0.64 & 2.42 & 58.32 & 19.19 \\
\hline $11 \mathrm{SN} 36-7.2$ & 3.57 & 12.64 & 484.07 & 1139.96 & 58.81 & 2713.84 & 743.96 & 19.93 & 79.46 & 203.13 & 382.31 \\
\hline 11 SN36-8.1 & 0.97 & 0.08 & 2.60 & 20.59 & 1.34 & 20.48 & 203.85 & 0.56 & 4.10 & 52.60 & 25.61 \\
\hline $11 \mathrm{SN} 36-8.2$ & 2.16 & 0.34 & 1.37 & 21.57 & 1.49 & 11.99 & 110.81 & 0.61 & 2.79 & 90.18 & 16.40 \\
\hline 11SN37-1.1 & 5.94 & 0.26 & 1.30 & 3.75 & 2.96 & 15.21 & 177.54 & 1.22 & 2.86 & 76.60 & 17.62 \\
\hline 11SN37-1.2 & 2.09 & 0.53 & 8.22 & 17.32 & 12.05 & 260.80 & 132.52 & 5.85 & 5.62 & 105.80 & 94.63 \\
\hline 11SN37-2.1 & 2.78 & 0.23 & 1.82 & 3.72 & 1.97 & 46.94 & 161.68 & 1.90 & 3.44 & 292.82 & 43.12 \\
\hline $11 \mathrm{SN} 37-2.2$ & 1.64 & 1.87 & 35.39 & 449.02 & 6.73 & 896.69 & 817.12 & 2.95 & 25.62 & 184.79 & 441.42 \\
\hline 11SN37-3.1 & 3.60 & 0.14 & 0.87 & 12.90 & 0.76 & 6.14 & 100.69 & 0.44 & 0.88 & 118.15 & 9.54 \\
\hline $11 \mathrm{SN} 37-3.2$ & 1.06 & 0.11 & 2.09 & 36.32 & 0.96 & 21.71 & 212.43 & 0.40 & 1.40 & 68.01 & 14.36 \\
\hline 11SN37-4.1 & 1.35 & 0.06 & 0.86 & 19.96 & 0.17 & 10.48 & 143.93 & 0.09 & 0.33 & 57.73 & 16.17 \\
\hline $11 \mathrm{SN} 37-4.2$ & 2.08 & 0.74 & 75.49 & 371.22 & 6.45 & 692.56 & 164.95 & 2.51 & 13.61 & 41.80 & 279.55 \\
\hline 11SN37-5.1 & 3.57 & 0.11 & 1.81 & 64.31 & 2.49 & 15.35 & 247.34 & 1.10 & 2.50 & 34.42 & 23.26 \\
\hline $11 \mathrm{SN} 37-5.2$ & 0.98 & 0.08 & 2.46 & 51.70 & 1.77 & 13.06 & 450.23 & 0.78 & 2.72 & 101.49 & 20.09 \\
\hline 11 SN37-6.1 & 1.31 & 0.09 & 1.06 & 35.47 & 1.82 & 12.41 & 74.59 & 0.63 & 2.09 & 45.19 & 7.91 \\
\hline $11 \mathrm{SN} 37-6.2$ & 4.98 & 0.11 & 1.11 & 30.34 & 1.49 & 12.12 & 83.94 & 0.71 & 2.21 & 48.14 & 7.86 \\
\hline
\end{tabular}




\begin{tabular}{|c|c|c|c|c|c|c|c|c|c|c|c|}
\hline & $\mathbf{L i}$ & $\mathbf{B e}$ & B & $\mathbf{F}$ & $\mathbf{N a}$ & Al & $\mathbf{P}$ & $\mathbf{K}$ & $\mathbf{C a}$ & Sc & $48 \mathrm{Ti}$ \\
\hline 11 SN37-7.1 & 1.80 & 0.18 & 4.28 & 49.28 & 2.29 & 121.78 & 134.78 & 1.19 & 3.14 & 85.20 & 19.39 \\
\hline $11 \mathrm{SN} 37-7.2$ & 2.42 & 0.34 & 18.39 & 102.19 & 6.93 & 525.49 & 98.88 & 9.12 & 12.45 & 62.77 & 22.87 \\
\hline 11SN37-8.1 & 1.97 & 0.20 & 1.20 & 42.88 & 1.81 & 11.23 & 229.54 & 0.76 & 1.81 & 67.66 & 12.95 \\
\hline $11 \mathrm{SN} 37-8.2$ & 1.54 & 0.14 & 2.93 & 58.65 & 2.58 & 72.04 & 272.14 & 1.21 & 1.92 & 136.84 & 12.82 \\
\hline 11SN38-1.1 & 1.17 & 0.03 & 7.69 & 57.16 & 2.45 & 234.72 & 428.24 & 1.16 & 4.09 & 109.97 & 28.64 \\
\hline 11SN38-1.2 & 2.69 & 0.03 & 6.51 & 67.58 & 4.96 & 20.80 & 236.87 & 4.35 & 6.76 & 47.11 & 28.57 \\
\hline $11 \mathrm{SN} 38-1.3$ & 0.95 & 0.04 & 1.52 & 32.08 & 1.47 & 11.49 & 252.09 & 0.62 & 2.08 & 56.25 & 15.86 \\
\hline 11SN38-2.1 & 1.90 & 0.01 & 1.16 & 38.26 & 1.54 & 11.63 & 335.88 & 0.62 & 2.16 & 52.85 & 12.52 \\
\hline $11 \mathrm{SN} 38-2.2$ & 0.75 & 0.04 & 4.19 & 35.62 & 1.32 & 10.33 & 212.99 & 0.59 & 2.11 & 61.67 & 13.91 \\
\hline 11SN38-3.1 & 0.65 & 0.03 & 4.24 & 270.97 & 1.91 & 12.65 & 161.49 & 2.55 & 7.71 & 21.56 & 12.89 \\
\hline $11 \mathrm{SN} 38-3.2$ & 1.33 & 0.04 & 6.91 & 73.00 & 1.99 & 11.94 & 291.83 & 1.06 & 5.71 & 60.33 & 17.31 \\
\hline 11SN38-4.1 & 2.22 & 0.03 & 1.71 & 23.09 & 2.03 & 16.53 & 128.16 & 0.93 & 2.21 & 36.67 & 14.68 \\
\hline $11 \mathrm{SN} 38-4.2$ & 0.80 & 0.06 & 2.04 & 33.20 & 1.57 & 10.96 & 230.38 & 0.75 & 2.82 & 52.12 & 16.56 \\
\hline $11 \mathrm{SN} 38-5.1$ & 1.29 & 0.03 & 2.58 & 168.25 & 2.04 & 13.86 & 307.42 & 1.11 & 25.42 & 64.70 & 18.85 \\
\hline $11 \mathrm{SN} 38-5.2$ & 0.70 & 0.09 & 154.37 & 212.59 & 269.65 & 3925.60 & 797.72 & 1527.46 & 134.36 & 132.45 & 64.32 \\
\hline 11SN38-6.1 & 0.69 & 0.10 & 44.22 & 123.52 & 6.90 & 1134.18 & 688.09 & 2.94 & 8.21 & 140.15 & 57.27 \\
\hline 11SN38-6.2 & 2.05 & 0.00 & 0.75 & 20.86 & 1.94 & 10.28 & 214.64 & 0.59 & 2.31 & 49.77 & 14.57 \\
\hline 11SN38-7.1 & 4.22 & 0.03 & 2.76 & 50.22 & 3.30 & 589.05 & 131.45 & 6.26 & 7.81 & 37.60 & 21.96 \\
\hline $11 \mathrm{SN} 38-7.2$ & 0.36 & 0.00 & 1.74 & 21.52 & 1.60 & 18.74 & 234.72 & 0.55 & 2.73 & 48.38 & 22.91 \\
\hline 11SN38-8.1 & 1.65 & 0.00 & 1.00 & 20.81 & 1.27 & 9.78 & 227.93 & 0.61 & 2.35 & 34.61 & 19.83 \\
\hline $11 \mathrm{SN} 38-8.2$ & 0.39 & 0.00 & 1.49 & 219.59 & 2.13 & 10.90 & 1169.88 & 0.52 & 566.36 & 88.22 & 17.45 \\
\hline $11 \mathrm{SN} 38-8.3$ & 1.39 & 0.03 & 1.48 & 20.03 & 1.24 & 11.87 & 139.58 & 0.44 & 1.93 & 23.38 & 10.69 \\
\hline 11SN40-1.1 & 0.34 & 0.00 & 3.05 & 25.94 & 2.71 & 18.75 & 256.08 & 1.31 & 5.90 & 72.68 & 25.18 \\
\hline 11SN40-1.2 & 1.18 & 0.12 & 2.09 & 23.72 & 2.17 & 21.28 & 115.32 & 1.08 & 6.24 & 161.74 & 16.42 \\
\hline 11SN40-2.1 & 0.96 & 0.36 & 2.56 & 185.23 & 3.46 & 25.71 & 345.50 & 1.87 & 11.90 & 66.15 & 28.63 \\
\hline $11 \mathrm{SN} 40-2.2$ & 2.33 & 0.20 & 2.13 & 219.37 & 2.17 & 16.34 & 332.67 & 0.77 & 31.65 & 86.02 & 21.68 \\
\hline 11 SN40-3.1 & 14.21 & 0.27 & 19.15 & 222.55 & 5.71 & 838.33 & 2078.62 & 2.72 & 15.36 & 53.17 & 49.39 \\
\hline $11 \mathrm{SN} 40-3.2$ & 0.69 & 0.09 & 6.12 & 55.85 & 4.83 & 30.79 & 174.20 & 2.04 & 9.02 & 61.46 & 19.30 \\
\hline $11 \mathrm{SN} 40-4.1$ & 0.89 & 0.54 & 1.45 & 43.73 & 4.14 & 49.18 & 169.14 & 1.74 & 8.03 & 70.94 & 31.64 \\
\hline $11 \mathrm{SN} 40-4.2$ & 1.79 & 0.12 & 2.17 & 46.39 & 4.53 & 25.87 & 139.42 & 1.86 & 6.27 & 135.33 & 20.26 \\
\hline
\end{tabular}




\begin{tabular}{|c|c|c|c|c|c|c|c|c|c|c|c|}
\hline & $\mathbf{L i}$ & $\mathbf{B e}$ & B & $\mathbf{F}$ & $\mathbf{N a}$ & Al & $\mathbf{P}$ & $\mathbf{K}$ & $\mathbf{C a}$ & Sc & $48 \mathrm{Ti}$ \\
\hline 11SN40-5.1 & 0.26 & 0.00 & 2.67 & 106.71 & 3.01 & 24.17 & 145.09 & 1.66 & 9.05 & 28.83 & 28.80 \\
\hline $11 \mathrm{SN} 40-5.2$ & 2.02 & 0.09 & 1.60 & 32.33 & 2.85 & 26.42 & 193.63 & 1.33 & 22.52 & 95.77 & 28.39 \\
\hline 11SN40-6.1 & 0.07 & 0.00 & 2.57 & 53.44 & 2.74 & 23.22 & 753.92 & 1.36 & 6.73 & 218.17 & 47.96 \\
\hline $11 \mathrm{SN} 40-6.2$ & 2.51 & 0.18 & 2.15 & 54.21 & 2.65 & 28.88 & 249.66 & 0.96 & 6.46 & 163.66 & 22.31 \\
\hline $11 \mathrm{SN} 40-7.1$ & 4.67 & 0.69 & 3.40 & 34.72 & 2.80 & 30.45 & 1126.53 & 1.16 & 4.33 & 142.22 & 35.66 \\
\hline 11SN40-7.2 & 1.47 & 0.12 & 1.59 & 38.41 & 2.41 & 21.46 & 249.90 & 1.14 & 4.23 & 52.57 & 25.39 \\
\hline 11SN40-9.1 & 0.33 & 0.00 & 1.36 & 53.19 & 1.34 & 18.11 & 601.72 & 0.73 & 3.22 & 99.63 & 31.20 \\
\hline 11SN40-9.2 & 3.28 & 0.00 & 2.45 & 34.56 & 1.88 & 20.83 & 117.28 & 1.09 & 3.81 & 52.62 & 20.79 \\
\hline 11SN40-10.1 & 5.41 & 0.16 & 2.86 & 32.96 & 2.01 & 141.55 & 217.31 & 1.07 & 5.85 & 87.70 & 37.08 \\
\hline 11SN40-10.2 & 0.37 & 0.06 & 2.41 & 43.09 & 2.00 & 20.43 & 364.58 & 1.01 & 5.26 & 145.65 & 39.33 \\
\hline 11SN41-1.1 & 1.79 & 0.00 & 2.99 & 160.78 & 6.59 & 46.08 & 357.08 & 2.87 & 19.59 & 94.55 & 51.87 \\
\hline 11SN41-1.2 & 1.29 & 0.00 & 4.56 & 30.94 & 2.37 & 25.01 & 374.01 & 1.16 & 8.51 & 66.88 & 35.20 \\
\hline $11 \mathrm{SN} 41-2.1$ & 0.24 & 0.06 & 2.72 & 114.65 & 2.96 & 28.00 & 437.60 & 1.87 & 11.01 & 105.74 & 39.88 \\
\hline $11 \mathrm{SN} 41-2.2$ & 1.14 & 0.00 & 2.32 & 69.25 & 3.04 & 26.52 & 292.08 & 1.70 & 9.16 & 65.37 & 37.88 \\
\hline 11SN41-3.1 & 2.71 & 0.61 & 5.34 & 90.82 & 3.07 & 28.57 & 247.89 & 1.52 & 9.84 & 166.53 & 19.14 \\
\hline $11 \mathrm{SN} 41-3.2$ & 1.39 & 0.13 & 42.08 & 101.91 & 4.90 & 2031.11 & 319.63 & 17.08 & 37.90 & 47.50 & 130.41 \\
\hline 11SN41-4.2 & 0.38 & 0.06 & 3.07 & 46.70 & 2.72 & 30.16 & 209.28 & 1.57 & 10.76 & 61.62 & 68.00 \\
\hline 11SN41-5.1 & 0.65 & 0.03 & 1.81 & 32.72 & 1.98 & 19.29 & 168.96 & 1.07 & 6.43 & 38.44 & 20.40 \\
\hline 11SN41-5.2 & 1.22 & 0.06 & 1.74 & 51.08 & 2.74 & 22.67 & 510.48 & 1.12 & 9.09 & 110.51 & 32.82 \\
\hline 11SN41-7.1 & 1.56 & 0.12 & 3.92 & 106.94 & 2.50 & 26.22 & 291.09 & 1.14 & 9.41 & 52.07 & 35.25 \\
\hline 11SN41-7.2 & 2.28 & 0.15 & 3.27 & 475.14 & 2.43 & 27.37 & 936.14 & 1.64 & 9.60 & 143.41 & 37.98 \\
\hline 11 SN41-8.1 & 0.96 & 0.06 & 3.02 & 4324.65 & 27.89 & 922.19 & 2619.85 & 578.27 & 1881.40 & 48.68 & 29.64 \\
\hline $11 \mathrm{SN} 41-8.2$ & 0.54 & 0.00 & 1.81 & 51.80 & 2.63 & 33.82 & 509.62 & 1.50 & 8.36 & 154.30 & 38.91 \\
\hline 11SN41-9.1 & 0.28 & 0.03 & 2.88 & 43.48 & 1.90 & 22.22 & 268.65 & 0.93 & 4.62 & 60.92 & 34.82 \\
\hline 11SN41-9.2 & 0.80 & 0.06 & 1.29 & 46.90 & 3.66 & 21.40 & 232.80 & 0.90 & 5.97 & 56.03 & 24.07 \\
\hline 11SN41-10.1 & 2.11 & 0.00 & 2.29 & 54.33 & 2.05 & 27.19 & 592.93 & 1.13 & 6.71 & 83.72 & 27.53 \\
\hline $11 \mathrm{SN} 41-10.2$ & 0.55 & 0.12 & 3.55 & 63.00 & 1.99 & 20.85 & 339.30 & 0.89 & 6.94 & 60.07 & 22.86 \\
\hline 11SN41-11.1 & 0.67 & 0.09 & 2.63 & 42.55 & 1.66 & 22.63 & 251.69 & 1.11 & 4.54 & 54.92 & 20.92 \\
\hline 11SN41-11.2 & 1.05 & 0.00 & 1.09 & 45.53 & 1.88 & 24.44 & 243.95 & 0.96 & 6.17 & 51.02 & 21.80 \\
\hline $11 \mathrm{SN} 41-11.3$ & 0.22 & 0.06 & 1.73 & 59.90 & 1.86 & 20.70 & 251.35 & 1.31 & 4.34 & 38.63 & 18.41 \\
\hline
\end{tabular}




\begin{tabular}{|c|c|c|c|c|c|c|c|c|c|c|c|}
\hline & 49Ti & $\mathbf{F e}$ & $\mathbf{Y}$ & $\mathbf{N b}$ & $\mathbf{L a}$ & $\mathrm{Ce}$ & Nd & Sm & Eu & Gd & Ho \\
\hline CS01-1.1 & 43.26 & 15.96 & 4935.27 & 285.17 & 0.492 & 481.67 & 3.90 & 9.41 & 0.78 & 75.05 & 192.72 \\
\hline CS01-1.2 & 54.70 & 8.12 & 3458.06 & 48.88 & 2.287 & 246.75 & 5.62 & 10.76 & 1.12 & 63.72 & 126.89 \\
\hline CS01-2.1 & 19.56 & 7.28 & 2538.68 & 115.18 & 0.080 & 206.41 & 1.67 & 3.10 & 0.45 & 37.57 & 102.28 \\
\hline CS01-2.2 & 96.24 & 160.03 & 1515.55 & 68.80 & 0.356 & 219.30 & 8.55 & 9.63 & 1.32 & 43.11 & 62.74 \\
\hline CS01-3.1 & 22.26 & 3.40 & 2281.40 & 129.57 & 0.051 & 451.56 & 1.23 & 3.93 & 0.33 & 37.17 & 83.02 \\
\hline CS01-3.2 & 30.92 & 2.70 & 3387.05 & 95.42 & 0.106 & 456.02 & 1.88 & 5.60 & 0.99 & 54.68 & 134.03 \\
\hline CS01-4.1 & 35.93 & 7.28 & 6548.73 & 247.68 & 0.099 & 412.58 & 11.17 & 21.52 & 2.25 & 150.06 & 265.63 \\
\hline CS01-4.2 & 36.30 & 7.99 & 4437.73 & 178.16 & 0.099 & 312.79 & 9.28 & 15.56 & 1.83 & 122.78 & 187.96 \\
\hline CS01-5.1 & 21.81 & 5.37 & 2518.38 & 132.12 & 0.113 & 496.58 & 1.41 & 3.85 & 0.37 & 34.09 & 90.60 \\
\hline CS01-5.2 & 30.76 & 11.32 & 3576.46 & 160.59 & 1.673 & 879.95 & 18.18 & 9.56 & 0.85 & 61.71 & 132.17 \\
\hline CS01-6.1 & 37.65 & 2.47 & 1531.32 & 40.57 & 0.072 & 114.67 & 0.83 & 1.87 & 0.26 & 22.56 & 56.93 \\
\hline CS01-7.1 & 177.49 & 764.68 & 3156.21 & 144.47 & 4.939 & 1376.11 & 16.25 & 11.04 & 2.59 & 65.09 & 105.43 \\
\hline CS01-8.1 & 30.25 & 5.21 & 6087.04 & 82.11 & 0.080 & 328.81 & 24.89 & 29.42 & 4.11 & 167.65 & 257.38 \\
\hline CS01-8.2 & 46.57 & 4.87 & 2593.17 & 77.49 & 0.036 & 237.66 & 4.17 & 7.69 & 1.09 & 49.73 & 94.77 \\
\hline CS01-9.1 & 48.02 & 36.64 & 682.87 & 29.86 & 0.536 & 141.43 & 3.04 & 1.25 & 0.23 & 4.38 & 19.37 \\
\hline CS01-10.1 & 23.40 & 10.18 & 2280.36 & 92.59 & 2.216 & 332.88 & 9.05 & 2.07 & 1.03 & 52.42 & 101.99 \\
\hline CS01-10.2 & 57.85 & 5.68 & 3755.66 & 156.23 & 0.093 & 394.41 & 5.61 & 3.81 & 1.07 & 67.09 & 137.61 \\
\hline CS01-11.1 & 54.26 & 5.51 & 3395.01 & 70.36 & 0.142 & 191.33 & 6.74 & 11.30 & 1.07 & 73.02 & 130.92 \\
\hline CS03-1.1 & 18.48 & 9.16 & 773.22 & 30.25 & 106.347 & 1762.74 & 112.76 & 11.56 & 0.96 & 22.36 & 24.86 \\
\hline CS03-1.2 & 18.50 & 1.64 & 874.76 & 21.26 & 0.077 & 42.38 & 1.12 & 2.23 & 0.40 & 21.16 & 32.36 \\
\hline CS03-2.1 & 19.99 & 4.15 & 2857.06 & 37.55 & 0.082 & 283.13 & 4.74 & 9.32 & 1.54 & 72.97 & 106.88 \\
\hline CSO3-2.2 & 36.75 & 13.91 & 1304.72 & 61.16 & 0.825 & 453.33 & 2.59 & 1.70 & 0.62 & 19.00 & 43.98 \\
\hline CS03-3.1 & 27.35 & 2.24 & 2133.55 & 26.65 & 0.078 & 340.56 & 7.04 & 8.69 & 2.24 & 59.31 & 87.18 \\
\hline CS03-4.1 & 25.89 & 3.45 & 626.66 & 15.38 & 0.092 & 135.57 & 2.12 & 2.68 & 0.72 & 11.88 & 21.64 \\
\hline CSO3-4.2 & 32.31 & 4.16 & 3136.56 & 56.74 & 0.110 & 729.52 & 11.07 & 15.21 & 2.70 & 98.13 & 135.91 \\
\hline CS03-6.1 & 41.57 & 1.54 & 883.88 & 18.98 & 0.053 & 123.49 & 1.43 & 3.36 & 0.59 & 20.41 & 33.45 \\
\hline CS03-6.2 & 41.49 & 2.13 & 918.19 & 23.47 & 0.046 & 145.92 & 2.25 & 3.19 & 0.63 & 17.81 & 31.89 \\
\hline CS03-7.1 & 33.89 & 12.34 & 2973.13 & 43.06 & 0.924 & 638.44 & 10.54 & 12.70 & 2.23 & 73.15 & 116.97 \\
\hline CS03-7.2 & 25.62 & 2.61 & 1797.21 & 74.69 & 0.058 & 385.76 & 1.92 & 3.17 & 0.77 & 26.42 & 58.18 \\
\hline
\end{tabular}




\begin{tabular}{|c|c|c|c|c|c|c|c|c|c|c|c|}
\hline & $49 \mathrm{Ti}$ & $\mathbf{F e}$ & $\mathbf{Y}$ & $\mathrm{Nb}$ & $\mathbf{L a}$ & $\mathrm{Ce}$ & Nd & Sm & Eu & Gd & Ho \\
\hline CS03-8.1 & 20.15 & 2.57 & 811.72 & 13.93 & 0.061 & 180.89 & 0.87 & 1.67 & 0.22 & 14.15 & 36.50 \\
\hline CS03-8.2 & 23.19 & 3.13 & 1098.27 & 47.15 & 0.074 & 210.32 & 1.12 & 2.77 & 0.35 & 14.60 & 37.18 \\
\hline CS03-8.3 & 30.45 & 27.25 & 1077.24 & 48.25 & 0.142 & 271.69 & 1.48 & 3.05 & 0.40 & 12.88 & 34.21 \\
\hline CS03-9.1 & 7.44 & 58.14 & 117.87 & 5.63 & 0.118 & 46.38 & 0.88 & 1.27 & 0.08 & 3.62 & 7.62 \\
\hline CS03-9.2 & 18.85 & 3.35 & 432.68 & 15.65 & 0.038 & 106.95 & 0.46 & 1.09 & 0.16 & 3.34 & 12.54 \\
\hline CS03-10.1 & 38.44 & 11.19 & 2716.91 & 51.97 & 0.281 & 565.16 & 7.91 & 11.81 & 1.78 & 68.88 & 108.65 \\
\hline CS03-10.2 & 30.55 & 3.33 & 1001.30 & 27.78 & 0.117 & 246.91 & 1.40 & 1.79 & 0.51 & 16.19 & 39.72 \\
\hline CS03-11.1 & 38.23 & 163.93 & 1129.25 & 21.59 & 0.163 & 201.16 & 3.19 & 5.17 & 1.04 & 30.48 & 38.14 \\
\hline CS03-11.2 & 22.78 & 2.92 & 1381.16 & 43.93 & 0.048 & 299.20 & 1.40 & 3.54 & 0.71 & 23.49 & 50.18 \\
\hline CS07-1.1 & 32.00 & 2.36 & 2839.77 & 67.30 & 0.073 & 223.36 & 3.20 & 5.74 & 1.10 & 37.20 & 104.08 \\
\hline CS07-1.2 & 19.60 & 1.42 & 894.19 & 16.53 & 0.050 & 79.65 & 0.64 & 1.62 & 0.37 & 13.39 & 33.04 \\
\hline CS07-1.3 & 22.60 & 4.03 & 3830.02 & 40.34 & 0.041 & 353.53 & 10.35 & 13.59 & 2.00 & 87.02 & 148.93 \\
\hline CS07-2.1 & 15.45 & 2.94 & 2874.13 & 140.88 & 0.077 & 667.36 & 2.86 & 5.96 & 0.49 & 50.02 & 109.73 \\
\hline CS07-2.2 & 9.42 & 5.02 & 1239.05 & 45.63 & 0.035 & 142.59 & 0.48 & 1.89 & 0.17 & 15.10 & 42.99 \\
\hline CS07-3.1 & 33.72 & 2.40 & 1494.11 & 24.85 & 0.015 & 187.73 & 1.93 & 4.43 & 0.44 & 30.04 & 57.94 \\
\hline CS07-3.2 & 40.40 & 1.25 & 2109.26 & 26.35 & 0.039 & 185.74 & 6.45 & 9.58 & 1.11 & 53.65 & 80.85 \\
\hline CS07-4.1 & 7.32 & 3.82 & 554.75 & 26.40 & 0.022 & 150.97 & 0.54 & 0.65 & 0.09 & 6.30 & 19.44 \\
\hline CS07-4.2 & 29.89 & 1.49 & 1173.50 & 31.49 & 0.038 & 216.09 & 1.17 & 3.12 & 0.41 & 22.31 & 44.69 \\
\hline CS07-4.3 & 17.24 & 5.35 & 1577.75 & 48.23 & 0.016 & 320.45 & 2.06 & 3.41 & 0.32 & 22.15 & 54.80 \\
\hline CS07-5.1 & 31.67 & 1.21 & 1713.91 & 16.11 & 0.029 & 175.43 & 2.15 & 4.52 & 0.52 & 31.37 & 48.74 \\
\hline CS07-5.2 & 34.89 & 1.48 & 1240.85 & 23.13 & 0.040 & 169.28 & 1.96 & 2.89 & 0.45 & 25.73 & 48.13 \\
\hline CS07-6.1 & 14.35 & 3.10 & 2454.73 & 126.29 & 0.038 & 438.85 & 1.89 & 3.75 & 0.33 & 37.31 & 94.44 \\
\hline CS07-6.2 & 33.07 & 2.25 & 1885.16 & 37.27 & 0.062 & 82.17 & 1.06 & 2.39 & 0.31 & 21.41 & 74.10 \\
\hline CS07-6.3 & 32.85 & 1.95 & 1666.35 & 38.35 & 0.026 & 244.12 & 1.69 & 3.55 & 0.92 & 27.84 & 65.88 \\
\hline CS07-7.1 & 20.57 & 6.73 & 2080.97 & 103.63 & 0.033 & 472.55 & 2.24 & 3.60 & 0.35 & 30.36 & 78.96 \\
\hline CS07-7.2 & 44.52 & 17.06 & 6290.74 & 161.76 & 0.097 & 1673.55 & 26.68 & 30.55 & 4.60 & 176.33 & 251.76 \\
\hline CS10-1.1 & 17.53 & 2.52 & 988.44 & 23.13 & 0.102 & 253.92 & 1.82 & 2.04 & 0.59 & 12.74 & 29.32 \\
\hline CS10-1.2 & 26.28 & 3.89 & 2533.58 & 106.34 & 0.061 & 732.01 & 2.28 & 5.62 & 1.35 & 46.47 & 89.86 \\
\hline CS10-2.1 & 33.99 & 2.44 & 1363.51 & 40.27 & 0.102 & 255.46 & 2.35 & 3.68 & 0.74 & 24.99 & 48.16 \\
\hline CS10-2.2 & 32.26 & 2.18 & 1239.35 & 40.98 & 0.079 & 268.73 & 1.68 & 3.01 & 0.54 & 20.68 & 44.07 \\
\hline
\end{tabular}




\begin{tabular}{|c|c|c|c|c|c|c|c|c|c|c|c|}
\hline & $49 \mathrm{Ti}$ & $\mathbf{F e}$ & $\mathbf{Y}$ & $\mathrm{Nb}$ & $\mathbf{L a}$ & $\mathrm{Ce}$ & Nd & Sm & $\mathbf{E u}$ & Gd & Ho \\
\hline CS10-3.1 & 15.76 & 4.40 & 1629.77 & 80.44 & 0.308 & 562.26 & 1.90 & 4.45 & 0.80 & 31.13 & 61.48 \\
\hline CS10-3.2 & 19.04 & 2.39 & 856.22 & 30.78 & 0.053 & 262.75 & 0.99 & 1.15 & 0.32 & 11.86 & 27.08 \\
\hline CS10-3.3 & 15.84 & 2.88 & 1619.40 & 37.21 & 0.051 & 339.45 & 3.92 & 5.40 & 1.08 & 34.65 & 60.76 \\
\hline CS10-4.1 & 37.50 & 78.82 & 10274.29 & 241.40 & 1.425 & 2689.05 & 21.89 & 33.35 & 6.38 & 235.35 & 390.91 \\
\hline CS10-4.2 & 16.98 & 9.06 & 426.23 & 19.29 & 0.247 & 143.03 & 0.78 & 0.46 & 0.30 & 3.75 & 12.58 \\
\hline CS10-5.1 & 19.34 & 4.01 & 1377.70 & 35.31 & 0.092 & 353.10 & 1.48 & 2.22 & 0.62 & 21.39 & 36.57 \\
\hline CS10-5.2 & 22.31 & 2.87 & 1133.78 & 42.70 & 0.048 & 418.82 & 2.23 & 3.48 & 0.68 & 21.36 & 42.61 \\
\hline CS10-7.1 & 17.16 & 3.77 & 1429.17 & 15.41 & 0.069 & 308.88 & 3.79 & 5.31 & 1.23 & 29.65 & 45.92 \\
\hline CS10-7.2 & 28.96 & 3.32 & 1416.12 & 45.64 & 0.123 & 406.35 & 1.36 & 2.00 & 0.62 & 20.43 & 46.90 \\
\hline CS10-8.1 & 58.26 & 4.20 & 6118.51 & 143.79 & 0.065 & 1653.98 & 11.15 & 19.46 & 5.46 & 167.66 & 238.27 \\
\hline CS10-8.2 & 34.24 & 17.88 & 636.20 & 27.07 & 1.997 & 440.73 & 11.96 & 4.31 & 1.92 & 15.97 & 26.23 \\
\hline CS10-10.1 & 27.15 & 2.56 & 1695.14 & 66.13 & 0.078 & 597.88 & 1.96 & 3.65 & 0.87 & 28.37 & 58.54 \\
\hline CS10-10.2 & 21.22 & 4.06 & 1134.63 & 35.22 & 0.067 & 452.04 & 1.96 & 2.83 & 0.82 & 23.15 & 42.24 \\
\hline CS13-1.1 & 19.28 & 2.73 & 2008.87 & 78.70 & 0.046 & 286.19 & 1.18 & 2.54 & 0.31 & 23.42 & 66.17 \\
\hline CS13-1.2 & 25.28 & 3.01 & 973.04 & 67.21 & 0.045 & 280.22 & 0.91 & 1.64 & 0.23 & 16.06 & 35.14 \\
\hline CS13-2.1 & 24.60 & 5.16 & 4090.69 & 47.88 & 0.037 & 578.92 & 11.91 & 17.49 & 2.95 & 96.38 & 139.88 \\
\hline CS13-2.2 & 34.57 & 3.46 & 2209.11 & 66.73 & 0.060 & 377.30 & 2.48 & 4.60 & 1.10 & 45.44 & 89.94 \\
\hline CS13-3.1 & 36.49 & 13.30 & 1893.62 & 59.15 & 0.136 & 241.08 & 1.83 & 3.22 & 0.63 & 23.33 & 59.35 \\
\hline CS13-4.1 & 34.04 & 2.28 & 629.76 & 18.40 & 0.055 & 38.63 & 1.33 & 1.61 & 0.35 & 16.16 & 23.48 \\
\hline CS13-4.2 & 24.37 & 2.83 & 1798.63 & 32.27 & 0.089 & 113.69 & 4.43 & 7.10 & 0.62 & 53.09 & 81.39 \\
\hline CS13-5.1 & 23.47 & 10.08 & 2065.58 & 83.26 & 2.958 & 367.01 & 6.73 & 5.38 & 0.62 & 36.20 & 73.40 \\
\hline CS13-5.2 & 22.43 & 8.76 & 3774.03 & 57.90 & 0.319 & 298.44 & 12.16 & 16.65 & 2.49 & 105.80 & 141.49 \\
\hline CS13-5.3 & 23.88 & 7.02 & 1342.85 & 45.80 & 0.087 & 222.20 & 2.51 & 3.80 & 0.51 & 28.01 & 50.30 \\
\hline CS13-6.1 & 26.12 & 10.18 & 1296.12 & 50.77 & 0.083 & 147.70 & 1.86 & 3.14 & 0.29 & 24.35 & 50.60 \\
\hline CS13-6.2 & 21.33 & 5.25 & 1935.36 & 48.39 & 0.050 & 136.10 & 1.48 & 3.63 & 0.19 & 28.78 & 64.61 \\
\hline CS13-7.1 & 27.57 & 6.40 & 1607.79 & 16.46 & 0.497 & 176.44 & 4.72 & 6.56 & 0.97 & 29.84 & 57.48 \\
\hline CS13-7.2 & 20.32 & 16.66 & 1028.00 & 38.85 & 1.092 & 119.03 & 1.18 & 2.11 & 0.37 & 15.32 & 34.50 \\
\hline CS13-9.1 & 17.07 & 4.10 & 1199.98 & 16.58 & 0.120 & 133.25 & 2.66 & 4.82 & 0.65 & 33.95 & 49.92 \\
\hline CS13-9.2 & 27.04 & 11.37 & 1039.19 & 36.85 & 0.200 & 170.43 & 1.57 & 3.13 & 0.46 & 18.95 & 36.58 \\
\hline CS19-1.1 & 19.95 & 56.06 & 1205.24 & 21.24 & 0.068 & 296.19 & 1.93 & 2.64 & 0.94 & 24.18 & 42.69 \\
\hline
\end{tabular}




\begin{tabular}{|c|c|c|c|c|c|c|c|c|c|c|c|}
\hline & 49Ti & $\mathbf{F e}$ & $\mathbf{Y}$ & $\mathrm{Nb}$ & $\mathbf{L a}$ & $\mathrm{Ce}$ & Nd & $\mathrm{Sm}$ & Eu & Gd & Ho \\
\hline CS19-2.1 & 20.56 & 7.32 & 1807.51 & 49.99 & 0.081 & 740.42 & 5.50 & 8.87 & 3.16 & 72.96 & 88.12 \\
\hline CS19-2.2 & 26.57 & 10.46 & 2293.14 & 95.80 & 0.124 & 1159.31 & 8.54 & 12.78 & 4.44 & 97.93 & 108.92 \\
\hline CS19-3.1 & 20.16 & 12.58 & 446.99 & 12.65 & 20.745 & 1875.90 & 57.19 & 5.93 & 1.05 & 10.84 & 17.66 \\
\hline CS19-3.2 & 13.26 & 2.15 & 1348.82 & 57.55 & 0.032 & 248.48 & 0.70 & 3.21 & 0.26 & 23.91 & 66.52 \\
\hline CS19-4.1 & 12.74 & 7.05 & 630.55 & 14.37 & 0.137 & 180.54 & 0.81 & 1.41 & 0.39 & 9.99 & 20.71 \\
\hline CS19-4.2 & 47.09 & 26.94 & 11205.19 & 253.54 & 0.217 & 3440.78 & 32.62 & 42.40 & 11.80 & 281.66 & 364.38 \\
\hline CS19-5.1 & 41.24 & 732.57 & 1547.96 & 72.40 & 0.340 & 338.42 & 3.31 & 4.08 & 1.05 & 25.82 & 49.98 \\
\hline CS19-5.2 & 1162.49 & 1449.56 & 5867.71 & 185.57 & 118.937 & 8007.03 & 650.74 & 193.94 & 58.03 & 366.23 & 178.68 \\
\hline CS19-6.1 & 27.43 & 9.54 & 4210.86 & 80.29 & 0.069 & 1033.18 & 12.57 & 17.58 & 4.81 & 103.17 & 138.06 \\
\hline CS19-6.2 & 44.80 & 25.36 & 6887.85 & 131.59 & 0.297 & 2010.50 & 22.96 & 29.56 & 8.27 & 201.32 & 219.97 \\
\hline CS19-7.1 & 25.33 & 21.76 & 1059.98 & 21.89 & 1.144 & 365.81 & 5.37 & 4.17 & 1.05 & 18.71 & 29.86 \\
\hline CS19-7.2 & 83.32 & 104.69 & 1269.52 & 103.17 & 15.412 & 1337.56 & 21.36 & 5.17 & 3.00 & 48.99 & 55.34 \\
\hline CS25-1.1 & 23.75 & 5.31 & 2663.65 & 29.71 & 0.118 & 257.41 & 6.28 & 7.36 & 1.41 & 64.03 & 99.06 \\
\hline CS25-1.2 & 24.89 & 8.37 & 1319.46 & 44.19 & 0.074 & 318.14 & 1.57 & 3.61 & 0.35 & 23.83 & 47.54 \\
\hline CS25-2.1 & 21.51 & 12.62 & 2601.61 & 149.23 & 0.762 & 443.93 & 8.48 & 5.84 & 0.59 & 36.59 & 89.32 \\
\hline $\mathrm{CS} 25-2.2$ & 28.85 & 3.21 & 2054.26 & 24.22 & 0.126 & 274.33 & 2.90 & 4.82 & 0.59 & 35.78 & 67.64 \\
\hline CS25-3.1 & 31.46 & 3.99 & 2264.94 & 64.79 & 0.083 & 282.73 & 3.47 & 6.20 & 0.33 & 42.37 & 80.50 \\
\hline CS25-3.2 & 32.79 & 3.26 & 456.82 & 19.94 & 0.065 & 112.70 & 0.45 & 0.88 & 0.11 & 6.60 & 16.36 \\
\hline $\mathrm{CS} 25-4.1$ & 26.67 & 4.00 & 1266.34 & 31.30 & 0.048 & 212.27 & 1.54 & 2.97 & 0.39 & 26.40 & 54.51 \\
\hline $\mathrm{CS} 25-4.2$ & 30.03 & 5.13 & 1397.06 & 35.96 & 0.037 & 149.76 & 0.81 & 2.06 & 0.25 & 21.35 & 49.69 \\
\hline CS25-4.3 & 23.65 & 11.56 & 1284.98 & 53.73 & 1.353 & 391.65 & 2.77 & 2.73 & 0.60 & 23.75 & 61.34 \\
\hline CS25-6.1 & 31.38 & 8.40 & 1022.65 & 37.87 & 0.061 & 132.23 & 0.80 & 2.04 & 0.22 & 14.96 & 37.52 \\
\hline CS25-6.2 & 86.80 & 174.02 & 1191.78 & 28.53 & 255.683 & 2338.89 & 61.52 & 1.65 & 2.52 & 32.86 & 45.84 \\
\hline CS25-7.1 & 33.30 & 13.34 & 2286.98 & 26.42 & 0.550 & 344.62 & 3.47 & 7.79 & 0.97 & 46.88 & 89.50 \\
\hline CS25-7.2 & 124.32 & 466.28 & 624.93 & 43.02 & 5.926 & 486.93 & 5.55 & 2.01 & 0.87 & 8.30 & 22.09 \\
\hline CS25-8.1 & 27.85 & 6.80 & 1119.32 & 33.60 & 0.054 & 206.90 & 1.41 & 2.59 & 0.33 & 18.98 & 38.30 \\
\hline $\mathrm{CS} 25-8.2$ & 31.96 & 7.18 & 1661.37 & 45.66 & 0.093 & 204.95 & 1.63 & 3.32 & 0.36 & 25.04 & 58.81 \\
\hline $\mathrm{CS} 25-8.3$ & 32.81 & 19.02 & 1248.74 & 42.96 & 0.773 & 305.05 & 3.37 & 3.20 & 0.55 & 20.54 & 45.45 \\
\hline 11SN34-1.1 & 24.53 & 2.05 & 2103.71 & 20.74 & 0.016 & 168.39 & 4.79 & 6.34 & 1.44 & 50.97 & 78.19 \\
\hline 11SN34-1.2 & 13.26 & 4.60 & 2414.33 & 103.78 & 0.034 & 391.00 & 1.38 & 3.43 & 0.77 & 33.32 & 91.54 \\
\hline
\end{tabular}




\begin{tabular}{|c|c|c|c|c|c|c|c|c|c|c|c|}
\hline & $49 \mathrm{Ti}$ & $\mathbf{F e}$ & $\mathbf{Y}$ & $\mathrm{Nb}$ & $\mathbf{L a}$ & $\mathrm{Ce}$ & Nd & $\mathrm{Sm}$ & $\mathbf{E u}$ & Gd & Ho \\
\hline 11SN34-2.1 & 29.44 & 0.97 & 614.39 & 9.70 & 0.054 & 72.18 & 0.74 & 1.08 & 0.30 & 8.74 & 23.77 \\
\hline $11 \mathrm{SN} 34-2.2$ & 15.22 & 2.65 & 2152.26 & 90.66 & 0.020 & 351.17 & 1.28 & 3.42 & 0.55 & 31.34 & 77.47 \\
\hline 11SN34-3.1 & 177.13 & 466.23 & 10493.47 & 1114.07 & 119.912 & 3680.94 & 412.51 & 92.90 & 14.00 & 208.67 & 391.77 \\
\hline 11SN34-3.2 & 9.58 & 10.17 & 660.80 & 49.52 & 0.056 & 72.79 & 0.27 & 0.36 & 0.06 & 3.30 & 19.74 \\
\hline 11SN34-4.1 & 21.72 & 3.14 & 5396.52 & 78.67 & 0.048 & 804.87 & 6.85 & 16.55 & 2.51 & 137.38 & 257.73 \\
\hline $11 \mathrm{SN} 34-4.2$ & 39.41 & 24.07 & 1991.92 & 55.91 & 0.891 & 261.40 & 4.90 & 6.34 & 1.37 & 41.59 & 81.02 \\
\hline 11SN34-5.1 & 28.67 & 2.48 & 1232.05 & 31.32 & 0.037 & 144.54 & 0.94 & 2.46 & 0.46 & 18.25 & 42.79 \\
\hline $11 \mathrm{SN} 34-5.2$ & 19.14 & 6.35 & 2946.79 & 123.37 & 0.050 & 417.44 & 2.16 & 5.51 & 0.82 & 41.00 & 114.57 \\
\hline 11SN34-6.1 & 18.75 & 45.88 & 284.31 & 18.28 & 0.169 & 54.63 & 0.82 & 0.50 & 0.07 & 2.74 & 10.59 \\
\hline 11SN34-6.2 & 22.52 & 30.75 & 1496.51 & 35.46 & 1.642 & 176.22 & 3.32 & 2.64 & 0.54 & 19.05 & 50.49 \\
\hline $11 \mathrm{SN} 34-6.3$ & 114.68 & 87.06 & 8161.40 & 1138.60 & 43.635 & 2193.75 & 165.78 & 43.17 & 4.72 & 113.75 & 298.76 \\
\hline 11SN34-7.1 & 19.25 & 291.08 & 2617.05 & 142.83 & 0.101 & 379.54 & 1.90 & 4.00 & 0.61 & 34.84 & 92.64 \\
\hline $11 \mathrm{SN} 34-7.2$ & 25.30 & 2.64 & 1655.92 & 29.30 & 0.025 & 151.51 & 1.78 & 2.64 & 0.64 & 25.09 & 60.85 \\
\hline 11SN34-8.1 & 17.60 & 3.93 & 1504.49 & 46.39 & 0.030 & 249.82 & 0.38 & 2.19 & 0.28 & 23.72 & 56.85 \\
\hline 11SN34-8.2 & 19.21 & 8.03 & 4269.69 & 83.09 & 0.064 & 559.13 & 9.59 & 14.74 & 2.62 & 99.44 & 180.34 \\
\hline $11 \mathrm{SN} 35-1.1$ & 7.99 & 5.11 & 2545.58 & 27.79 & 0.027 & 353.60 & 2.58 & 6.67 & 0.79 & 41.44 & 82.96 \\
\hline 11SN35-1.2 & 59.64 & 12.15 & 1303.53 & 45.35 & 1.107 & 255.95 & 3.34 & 3.80 & 0.40 & 21.43 & 47.14 \\
\hline 11SN35-2.1 & 21.56 & 1.84 & 488.71 & 16.63 & 0.027 & 94.65 & 0.30 & 0.84 & 0.13 & 7.22 & 18.20 \\
\hline $11 \mathrm{SN} 35-2.2$ & 27.01 & 2.59 & 3423.99 & 26.44 & 0.084 & 188.27 & 15.99 & 18.61 & 2.44 & 120.33 & 166.72 \\
\hline 11SN35-3.1 & 14.31 & 5.00 & 1313.12 & 56.61 & 0.025 & 308.59 & 1.26 & 3.45 & 0.31 & 22.64 & 47.36 \\
\hline $11 \mathrm{SN} 35-3.2$ & 19.74 & 5.31 & 2885.66 & 43.90 & 3.058 & 391.39 & 7.16 & 7.48 & 0.85 & 48.28 & 79.10 \\
\hline 11SN35-4.1 & 12.31 & 4.19 & 1254.23 & 60.26 & 0.017 & 311.07 & 1.35 & 2.62 & 0.30 & 22.01 & 47.34 \\
\hline 11 SN35-4.2 & 45.80 & 1.75 & 2679.63 & 45.15 & 0.034 & 175.68 & 4.52 & 7.09 & 0.39 & 51.53 & 91.53 \\
\hline 11SN35-5.1 & 20.85 & 1.41 & 1645.36 & 21.45 & 0.039 & 209.28 & 1.91 & 3.30 & 1.05 & 25.35 & 59.27 \\
\hline $11 \mathrm{SN} 35-5.2$ & 13.37 & 6.83 & 2755.21 & 145.49 & 0.131 & 471.58 & 3.26 & 6.00 & 1.10 & 49.25 & 100.56 \\
\hline 11SN35-6.1 & 20.90 & 6.55 & 1435.82 & 48.49 & 0.017 & 320.64 & 1.49 & 3.29 & 0.39 & 26.09 & 51.81 \\
\hline $11 \mathrm{SN} 35-6.2$ & 27.41 & 12.00 & 1054.45 & 27.60 & 5.412 & 280.78 & 13.72 & 3.87 & 0.40 & 19.35 & 36.21 \\
\hline 11SN35-7.1 & 22.47 & 7.53 & 1387.79 & 35.40 & 0.112 & 288.32 & 2.81 & 3.45 & 0.57 & 26.98 & 46.82 \\
\hline $11 \mathrm{SN} 35-7.2$ & 19.39 & 6.80 & 2109.47 & 90.44 & 0.033 & 413.10 & 1.97 & 4.36 & 0.55 & 31.55 & 67.23 \\
\hline 11SN35-8.1 & 19.02 & 3.03 & 1388.62 & 48.47 & 0.017 & 294.14 & 1.56 & 2.91 & 0.36 & 22.28 & 49.48 \\
\hline $11 \mathrm{SN} 35-8.2$ & 19.60 & 4.28 & 1124.72 & 24.02 & 0.073 & 140.36 & 0.91 & 3.76 & 0.47 & 22.32 & 42.79 \\
\hline
\end{tabular}




\begin{tabular}{|c|c|c|c|c|c|c|c|c|c|c|c|}
\hline & 49Ti & $\mathbf{F e}$ & $\mathbf{Y}$ & $\mathrm{Nb}$ & $\mathbf{L a}$ & $\mathrm{Ce}$ & Nd & $\mathrm{Sm}$ & Eu & Gd & Ho \\
\hline $11 \mathrm{SN} 35-8.3$ & 28.30 & 5.52 & 1509.22 & 53.43 & 0.025 & 268.05 & 1.65 & 3.10 & 0.40 & 23.81 & 52.00 \\
\hline 11SN36-1.1 & 14.91 & 1.76 & 938.12 & 21.77 & 0.057 & 241.26 & 1.18 & 2.43 & 0.63 & 18.99 & 36.66 \\
\hline 11SN36-1.2 & 18.67 & 10.91 & 1965.92 & 98.62 & 0.028 & 975.06 & 4.07 & 6.11 & 1.20 & 41.82 & 65.08 \\
\hline 11SN36-2.1 & 21.58 & 4.86 & 2618.79 & 77.76 & 0.036 & 348.72 & 2.64 & 6.34 & 0.29 & 62.47 & 122.07 \\
\hline 11SN36-2.2 & 14.09 & 4.41 & 1965.07 & 29.35 & 0.029 & 258.79 & 4.47 & 5.48 & 0.96 & 29.91 & 55.42 \\
\hline 11SN36-3.1 & 11.86 & 1.96 & 996.40 & 23.17 & 0.049 & 235.98 & 1.00 & 1.53 & 0.44 & 11.10 & 30.62 \\
\hline 11SN36-3.2 & 13.88 & 6.80 & 2344.77 & 136.84 & 0.031 & 877.42 & 2.75 & 5.35 & 1.01 & 39.98 & 75.92 \\
\hline $11 \mathrm{SN} 36-4.1$ & 18.37 & 0.96 & 1083.83 & 25.56 & 0.020 & 167.61 & 1.81 & 3.61 & 0.86 & 24.16 & 39.04 \\
\hline $11 \mathrm{SN} 36-4.2$ & 26.77 & 3.23 & 2982.63 & 122.63 & 1.560 & 828.04 & 6.78 & 7.45 & 1.94 & 63.47 & 106.33 \\
\hline 11SN36-5.1 & 19.25 & 2.93 & 1000.41 & 52.01 & 0.070 & 190.59 & 1.01 & 1.86 & 0.11 & 12.09 & 37.32 \\
\hline 11SN36-5.2 & 20.62 & 3.58 & 2616.11 & 61.61 & 0.040 & 287.02 & 2.46 & 5.26 & 0.55 & 37.56 & 88.07 \\
\hline 11SN36-6.1 & 50.07 & 6.77 & 3242.52 & 43.40 & 0.315 & 822.28 & 10.79 & 10.74 & 1.70 & 64.39 & 104.60 \\
\hline 11SN36-6.2 & 50.41 & 372.36 & 778.26 & 156.37 & 4.343 & 415.56 & 40.90 & 14.51 & 2.19 & 29.65 & 27.13 \\
\hline 11SN36-7.1 & 20.61 & 1.53 & 1790.03 & 45.46 & 0.050 & 440.75 & 4.63 & 6.29 & 1.07 & 37.16 & 63.72 \\
\hline $11 \mathrm{SN} 36-7.2$ & 344.78 & 1102.24 & 4238.47 & 2290.55 & 89.170 & 4966.79 & 526.73 & 137.37 & 15.25 & 203.52 & 139.58 \\
\hline 11SN36-8.1 & 25.71 & 7.78 & 1178.75 & 39.63 & 0.952 & 316.33 & 10.02 & 5.96 & 1.18 & 30.71 & 42.79 \\
\hline $11 \mathrm{SN} 36-8.2$ & 16.39 & 4.58 & 1081.16 & 42.27 & 0.027 & 343.08 & 1.08 & 1.59 & 0.41 & 13.16 & 33.83 \\
\hline 11SN37-1.1 & 14.75 & 7.00 & 1253.36 & 41.84 & 0.041 & 619.97 & 2.77 & 4.04 & 1.03 & 29.18 & 44.19 \\
\hline $11 \mathrm{SN} 37-1.2$ & 93.52 & 621.69 & 1319.32 & 69.31 & 3.911 & 730.02 & 21.56 & 5.53 & 1.12 & 23.19 & 41.21 \\
\hline 11SN37-2.1 & 40.64 & 21.41 & 3223.96 & 190.92 & 3.558 & 986.14 & 15.21 & 4.28 & 0.82 & 28.65 & 91.44 \\
\hline $11 \mathrm{SN} 37-2.2$ & 432.47 & 194.30 & 6628.25 & 333.79 & 56.230 & 5695.93 & 205.48 & 47.45 & 9.63 & 166.52 & 254.04 \\
\hline 11SN37-3.1 & 10.32 & 4.69 & 1142.28 & 45.55 & 0.158 & 441.42 & 2.59 & 2.53 & 0.54 & 17.51 & 34.52 \\
\hline $11 \mathrm{SN} 37-3.2$ & 14.23 & 3.55 & 931.09 & 21.75 & 0.678 & 292.08 & 5.50 & 2.06 & 0.53 & 10.71 & 25.86 \\
\hline 11SN37-4.1 & 15.90 & 4.33 & 1647.63 & 35.09 & 0.231 & 402.00 & 4.69 & 6.92 & 1.18 & 34.63 & 59.94 \\
\hline $11 \mathrm{SN} 37-4.2$ & 269.65 & 60.75 & 495.93 & 122.24 & 30.537 & 2362.65 & 132.88 & 18.22 & 3.32 & 19.36 & 19.04 \\
\hline 11SN37-5.1 & 21.14 & 2.61 & 672.39 & 27.26 & 0.069 & 247.35 & 1.36 & 1.99 & 0.51 & 14.73 & 23.07 \\
\hline $11 \mathrm{SN} 37-5.2$ & 20.79 & 2.85 & 3513.20 & 71.56 & 0.033 & 772.10 & 12.28 & 16.40 & 2.74 & 102.71 & 135.56 \\
\hline 11SN37-6.1 & 7.07 & 1.50 & 583.15 & 14.65 & 0.027 & 150.96 & 0.79 & 1.17 & 0.38 & 8.63 & 17.73 \\
\hline $11 \mathrm{SN} 37-6.2$ & 7.66 & 2.74 & 511.17 & 19.80 & 0.026 & 201.62 & 0.33 & 1.22 & 0.29 & 6.60 & 15.87 \\
\hline
\end{tabular}




\begin{tabular}{|c|c|c|c|c|c|c|c|c|c|c|c|}
\hline & 49Ti & $\mathbf{F e}$ & $\mathbf{Y}$ & $\mathrm{Nb}$ & $\mathbf{L a}$ & $\mathrm{Ce}$ & Nd & $\mathrm{Sm}$ & Eu & Gd & Ho \\
\hline 11SN37-7.1 & 20.20 & 72.98 & 1273.58 & 44.86 & 1.729 & 510.54 & 10.44 & 2.77 & 0.87 & 17.89 & 41.40 \\
\hline $11 \mathrm{SN} 37-7.2$ & 23.25 & 379.40 & 601.62 & 38.55 & 13.979 & 980.52 & 70.26 & 8.17 & 1.36 & 15.08 & 21.07 \\
\hline 11SN37-8.1 & 14.36 & 2.86 & 2265.76 & 26.46 & 0.036 & 431.22 & 7.57 & 9.42 & 2.07 & 55.47 & 79.02 \\
\hline $11 \mathrm{SN} 37-8.2$ & 15.06 & 43.74 & 2195.61 & 51.98 & 0.081 & 678.62 & 2.68 & 4.78 & 0.89 & 37.36 & 75.11 \\
\hline 11SN38-1.1 & 26.01 & 205.44 & 3301.18 & 89.67 & 0.993 & 500.03 & 13.59 & 14.27 & 2.05 & 82.66 & 127.78 \\
\hline $11 \mathrm{SN} 38-1.2$ & 27.70 & 2.93 & 1149.76 & 49.59 & 0.076 & 350.95 & 1.71 & 2.44 & 0.42 & 20.35 & 39.88 \\
\hline $11 \mathrm{SN} 38-1.3$ & 16.77 & 2.11 & 1552.39 & 63.12 & 0.012 & 365.71 & 1.30 & 2.55 & 0.59 & 26.33 & 52.91 \\
\hline 11SN38-2.1 & 11.60 & 3.53 & 1101.17 & 35.81 & 0.056 & 248.48 & 0.77 & 1.76 & 0.42 & 17.01 & 36.03 \\
\hline $11 \mathrm{SN} 38-2.2$ & 14.12 & 2.14 & 1426.53 & 77.69 & 0.024 & 408.48 & 1.36 & 2.65 & 0.53 & 21.51 & 49.77 \\
\hline 11SN38-3.1 & 12.98 & 1.63 & 420.20 & 23.56 & 0.103 & 164.92 & 0.64 & 0.65 & 0.15 & 5.35 & 14.27 \\
\hline $11 \mathrm{SN} 38-3.2$ & 19.01 & 3.91 & 1578.07 & 64.44 & 0.087 & 375.25 & 1.53 & 3.55 & 0.67 & 26.27 & 53.69 \\
\hline $11 \mathrm{SN} 38-4.1$ & 15.64 & 3.33 & 616.65 & 25.69 & 0.048 & 238.83 & 0.81 & 1.65 & 0.28 & 11.23 & 20.35 \\
\hline $11 \mathrm{SN} 38-4.2$ & 15.20 & 2.19 & 2010.64 & 32.21 & 0.038 & 375.05 & 5.16 & 7.32 & 1.25 & 49.95 & 76.26 \\
\hline 11SN38-5.1 & 17.99 & 7.55 & 1591.96 & 58.96 & 0.253 & 429.07 & 2.26 & 3.42 & 0.67 & 25.38 & 56.04 \\
\hline 11SN38-5.2 & 59.25 & 51.22 & 6365.03 & 121.69 & 1.099 & 1471.16 & 26.37 & 33.37 & 5.52 & 189.33 & 262.65 \\
\hline 11SN38-6.1 & 55.34 & 30.73 & 5714.00 & 122.87 & 1.494 & 1421.19 & 27.94 & 27.10 & 5.05 & 146.24 & 206.20 \\
\hline 11SN38-6.2 & 14.54 & 2.36 & 1039.70 & 35.57 & 0.039 & 291.81 & 1.52 & 2.47 & 0.46 & 20.45 & 36.01 \\
\hline 11SN38-7.1 & 26.00 & 20.61 & 497.34 & 24.99 & 2.665 & 298.75 & 4.41 & 1.98 & 0.35 & 8.74 & 17.29 \\
\hline 11SN38-7.2 & 22.62 & 0.98 & 556.31 & 11.78 & 0.021 & 88.50 & 0.60 & 1.62 & 0.33 & 9.05 & 19.10 \\
\hline 11SN38-8.1 & 19.45 & 2.11 & 951.58 & 35.01 & 0.026 & 297.20 & 1.19 & 2.69 & 0.42 & 17.41 & 34.55 \\
\hline $11 \mathrm{SN} 38-8.2$ & 16.55 & 4.06 & 2717.10 & 138.19 & 5.904 & 495.82 & 10.12 & 7.18 & 0.59 & 45.35 & 106.42 \\
\hline $11 \mathrm{SN} 38-8.3$ & 11.48 & 1.60 & 614.19 & 28.24 & 0.032 & 206.65 & 0.31 & 1.15 & 0.21 & 8.59 & 20.56 \\
\hline 11SN40-1.1 & 25.51 & 3.14 & 1943.81 & 27.26 & 0.046 & 208.80 & 2.19 & 7.00 & 0.79 & 44.25 & 74.49 \\
\hline $11 \mathrm{SN} 40-1.2$ & 15.07 & 6.87 & 1726.42 & 81.05 & 0.074 & 199.10 & 0.71 & 2.48 & 0.58 & 22.37 & 56.76 \\
\hline 11SN40-2.1 & 29.13 & 7.69 & 2770.94 & 76.03 & 0.110 & 522.48 & 4.29 & 8.87 & 0.78 & 60.87 & 118.12 \\
\hline $11 \mathrm{SN} 40-2.2$ & 23.15 & 6.16 & 2913.94 & 134.58 & 0.510 & 735.52 & 6.02 & 10.19 & 0.97 & 61.32 & 134.94 \\
\hline 11SN40-3.1 & 47.25 & 58.18 & 5396.17 & 1027.25 & 3.924 & 373.94 & 29.23 & 11.94 & 1.18 & 58.08 & 179.03 \\
\hline $11 \mathrm{SN} 40-3.2$ & 17.30 & 5.62 & 1593.43 & 68.65 & 0.036 & 173.55 & 0.84 & 3.00 & 0.44 & 24.90 & 55.72 \\
\hline 11SN40-4.1 & 34.34 & 16.62 & 2282.17 & 45.35 & 0.090 & 261.59 & 2.60 & 6.50 & 1.00 & 46.72 & 86.57 \\
\hline $11 \mathrm{SN} 40-4.2$ & 18.14 & 5.94 & 2157.67 & 110.99 & 0.111 & 227.09 & 1.36 & 3.55 & 0.56 & 30.75 & 70.62 \\
\hline
\end{tabular}




\begin{tabular}{|c|c|c|c|c|c|c|c|c|c|c|c|}
\hline & 49Ti & $\mathrm{Fe}$ & $\mathbf{Y}$ & $\mathrm{Nb}$ & $\mathbf{L a}$ & $\mathrm{Ce}$ & Nd & $\mathrm{Sm}$ & Eu & Gd & Ho \\
\hline 11SN40-5.1 & 29.38 & 2.56 & 480.28 & 16.06 & 0.046 & 118.33 & 0.55 & 0.65 & 0.24 & 6.09 & 16.76 \\
\hline $11 \mathrm{SN} 40-5.2$ & 25.56 & 7.58 & 2333.93 & 161.82 & 0.046 & 497.76 & 2.81 & 5.70 & 0.88 & 44.70 & 85.83 \\
\hline 11 SN40-6.1 & 44.90 & 2.52 & 2288.11 & 23.20 & 0.078 & 157.57 & 5.15 & 9.95 & 2.21 & 57.29 & 86.68 \\
\hline $11 \mathrm{SN} 40-6.2$ & 22.59 & 8.50 & 3644.55 & 288.50 & 0.074 & 393.65 & 0.79 & 3.52 & 0.57 & 35.84 & 114.59 \\
\hline $11 \mathrm{SN} 40-7.1$ & 38.60 & 2.65 & 2801.59 & 51.26 & 0.100 & 299.69 & 4.37 & 5.96 & 0.77 & 49.34 & 98.38 \\
\hline $11 \mathrm{SN} 40-7.2$ & 22.26 & 3.46 & 1310.22 & 43.54 & 0.045 & 278.94 & 2.01 & 2.62 & 0.42 & 20.34 & 45.91 \\
\hline $11 \mathrm{SN} 40-9.1$ & 28.87 & 3.42 & 3723.94 & 57.29 & 0.114 & 527.15 & 9.37 & 15.27 & 1.60 & 83.53 & 140.59 \\
\hline 11SN40-9.2 & 18.95 & 5.90 & 1039.40 & 38.94 & 0.056 & 204.36 & 0.64 & 1.63 & 0.24 & 9.28 & 31.99 \\
\hline 11SN40-10.1 & 36.05 & 17.84 & 2578.49 & 242.58 & 0.218 & 397.80 & 1.09 & 3.04 & 0.36 & 24.00 & 82.03 \\
\hline 11SN40-10.2 & 40.32 & 3.88 & 2934.35 & 41.95 & 0.110 & 329.39 & 13.47 & 15.26 & 3.03 & 88.08 & 111.10 \\
\hline 11SN41-1.1 & 45.84 & 5.53 & 1774.64 & 51.68 & 0.130 & 325.31 & 2.86 & 5.94 & 0.68 & 25.92 & 63.30 \\
\hline $11 \mathrm{SN} 41-1.2$ & 36.35 & 3.76 & 1335.05 & 25.01 & 0.072 & 149.09 & 1.34 & 2.80 & 0.48 & 18.15 & 43.00 \\
\hline $11 \mathrm{SN} 41-2.1$ & 39.73 & 4.54 & 2630.02 & 35.13 & 0.104 & 408.34 & 3.98 & 9.36 & 1.22 & 72.00 & 113.64 \\
\hline $11 \mathrm{SN} 41-2.2$ & 40.52 & 3.29 & 1044.25 & 27.18 & 0.107 & 197.27 & 0.84 & 2.72 & 0.34 & 19.49 & 37.88 \\
\hline $11 \mathrm{SN} 41-3.1$ & 18.82 & 12.73 & 7561.10 & 142.78 & 0.086 & 501.51 & 6.96 & 11.82 & 2.54 & 112.84 & 296.92 \\
\hline 11SN41-3.2 & 121.07 & 1941.13 & 984.25 & 44.87 & 13.654 & 473.81 & 26.95 & 5.67 & 1.16 & 17.63 & 36.53 \\
\hline 11SN41-4.2 & 62.33 & 2.95 & 849.43 & 20.83 & 0.163 & 175.26 & 1.40 & 1.97 & 0.27 & 12.59 & 32.63 \\
\hline 11SN41-5.1 & 21.68 & 2.86 & 729.68 & 27.51 & 0.047 & 122.88 & 0.53 & 1.65 & 0.31 & 11.22 & 26.59 \\
\hline $11 \mathrm{SN} 41-5.2$ & 35.97 & 2.07 & 1685.06 & 24.70 & 0.089 & 188.17 & 2.97 & 4.33 & 0.57 & 30.11 & 67.50 \\
\hline $11 \mathrm{SN} 41-7.1$ & 37.69 & 4.37 & 1126.46 & 33.61 & 0.119 & 246.08 & 1.45 & 2.90 & 0.31 & 22.42 & 42.44 \\
\hline $11 \mathrm{SN} 41-7.2$ & 32.53 & 3.35 & 5003.42 & 61.39 & 0.332 & 562.94 & 15.63 & 17.40 & 2.07 & 122.02 & 193.66 \\
\hline $11 \mathrm{SN} 41-8.1$ & 27.27 & 261.89 & 1042.81 & 41.42 & 25.578 & 983.49 & 50.56 & 10.04 & 2.16 & 26.24 & 35.99 \\
\hline $11 \mathrm{SN} 41-8.2$ & 40.19 & 2.87 & 2610.92 & 21.70 & 0.149 & 142.47 & 9.17 & 12.81 & 2.85 & 81.52 & 102.05 \\
\hline 11SN41-9.1 & 30.95 & 2.32 & 823.44 & 22.78 & 0.054 & 176.37 & 0.34 & 1.32 & 0.21 & 14.65 & 33.83 \\
\hline $11 \mathrm{SN} 41-9.2$ & 26.81 & 2.59 & 1137.48 & 26.88 & 0.053 & 193.60 & 1.97 & 2.02 & 0.39 & 19.00 & 41.28 \\
\hline $11 \mathrm{SN} 41-10.1$ & 27.23 & 3.69 & 1471.41 & 34.90 & 0.087 & 153.18 & 1.49 & 3.17 & 0.33 & 25.42 & 54.01 \\
\hline $11 \mathrm{SN} 41-10.2$ & 25.59 & 4.06 & 1630.98 & 50.93 & 0.082 & 296.01 & 1.12 & 2.42 & 0.39 & 24.49 & 57.65 \\
\hline 11SN41-11.1 & 19.91 & 3.89 & 1419.16 & 59.38 & 0.063 & 253.98 & 0.85 & 2.88 & 0.30 & 17.89 & 51.10 \\
\hline $11 \mathrm{SN} 41-11.2$ & 20.42 & 2.75 & 758.23 & 21.32 & 0.104 & 140.56 & 1.08 & 1.51 & 0.27 & 9.60 & 27.95 \\
\hline $11 \mathrm{SN} 41-11.3$ & 19.81 & 2.51 & 1166.69 & 30.51 & 0.099 & 222.26 & 0.91 & 1.99 & 0.26 & 16.60 & 43.98 \\
\hline
\end{tabular}




\begin{tabular}{|c|c|c|c|c|c|c|c|c|c|c|}
\hline & $\mathbf{T b}$ & Dy & $\mathbf{E r}$ & $\mathbf{T m}$ & $\mathbf{Y b}$ & Lu & Hf & $\mathbf{P b}$ & Th & $\mathbf{U}$ \\
\hline CS01-1.1 & 30.33 & 387.84 & 937.46 & 222.98 & 1962.33 & 363.10 & 14070 & 35 & 1115 & 1495 \\
\hline CS01-2.1 & 16.47 & 221.32 & 512.38 & 115.09 & 1030.00 & 193.17 & 12289 & 22 & 884 & 985 \\
\hline CS01-3.1 & 14.19 & 186.77 & 451.26 & 109.74 & 980.07 & 179.33 & 10654 & 9 & 523 & 557 \\
\hline CS01-3.2 & 21.84 & 274.18 & 666.92 & 156.03 & 1358.66 & 251.14 & 10445 & 7 & 542 & 570 \\
\hline CS01-5.1 & 14.34 & 188.34 & 469.13 & 114.26 & 1094.37 & 209.65 & 13240 & 11 & 724 & 767 \\
\hline CS01-5.2 & 21.99 & 290.98 & 686.41 & 172.12 & 1633.55 & 304.06 & 13129 & 27 & 2447 & 2015 \\
\hline CS01-6.1 & 8.99 & 116.25 & 288.79 & 68.29 & 614.79 & 108.50 & 12144 & 4 & 148 & 174 \\
\hline CS01-7.1 & 22.69 & 252.34 & 503.04 & 118.04 & 1045.31 & 202.36 & 12162 & 22 & 3947 & 1984 \\
\hline CS01-8.1 & 56.92 & 624.14 & 1189.13 & 259.07 & 2302.13 & 405.11 & 8949 & 19 & 1525 & 925 \\
\hline CS01-10.2 & 23.42 & 294.67 & 703.20 & 178.54 & 1499.18 & 291.54 & 9971 & 13 & 1031 & 819 \\
\hline CS01-11.1 & 26.69 & 292.00 & 616.92 & 133.53 & 1136.99 & 199.85 & 10102 & 7 & 406 & 416 \\
\hline CS03-1.1 & 5.09 & 54.33 & 121.78 & 27.12 & 300.82 & 55.28 & 9047 & 5 & 282 & 375 \\
\hline CS03-1.2 & 6.85 & 81.35 & 142.24 & 31.45 & 309.02 & 53.77 & 11093 & 1 & 83 & 126 \\
\hline CS03-2.1 & 24.67 & 273.26 & 541.08 & 128.18 & 1130.70 & 208.53 & 13132 & 23 & 1673 & 1496 \\
\hline CSO3-2.2 & 5.56 & 89.98 & 233.01 & 70.29 & 759.11 & 162.79 & 12265 & 20 & 944 & 1224 \\
\hline CS03-3.1 & 18.62 & 197.71 & 402.59 & 94.66 & 890.99 & 183.18 & 8996 & 7 & 982 & 612 \\
\hline CS03-4.1 & 3.77 & 42.44 & 88.24 & 25.31 & 247.98 & 62.36 & 14108 & 7 & 383 & 591 \\
\hline $\mathrm{CS} 03-4.2$ & 31.22 & 320.33 & 641.28 & 137.38 & 1308.00 & 235.85 & 9809 & 25 & 2579 & 1579 \\
\hline
\end{tabular}




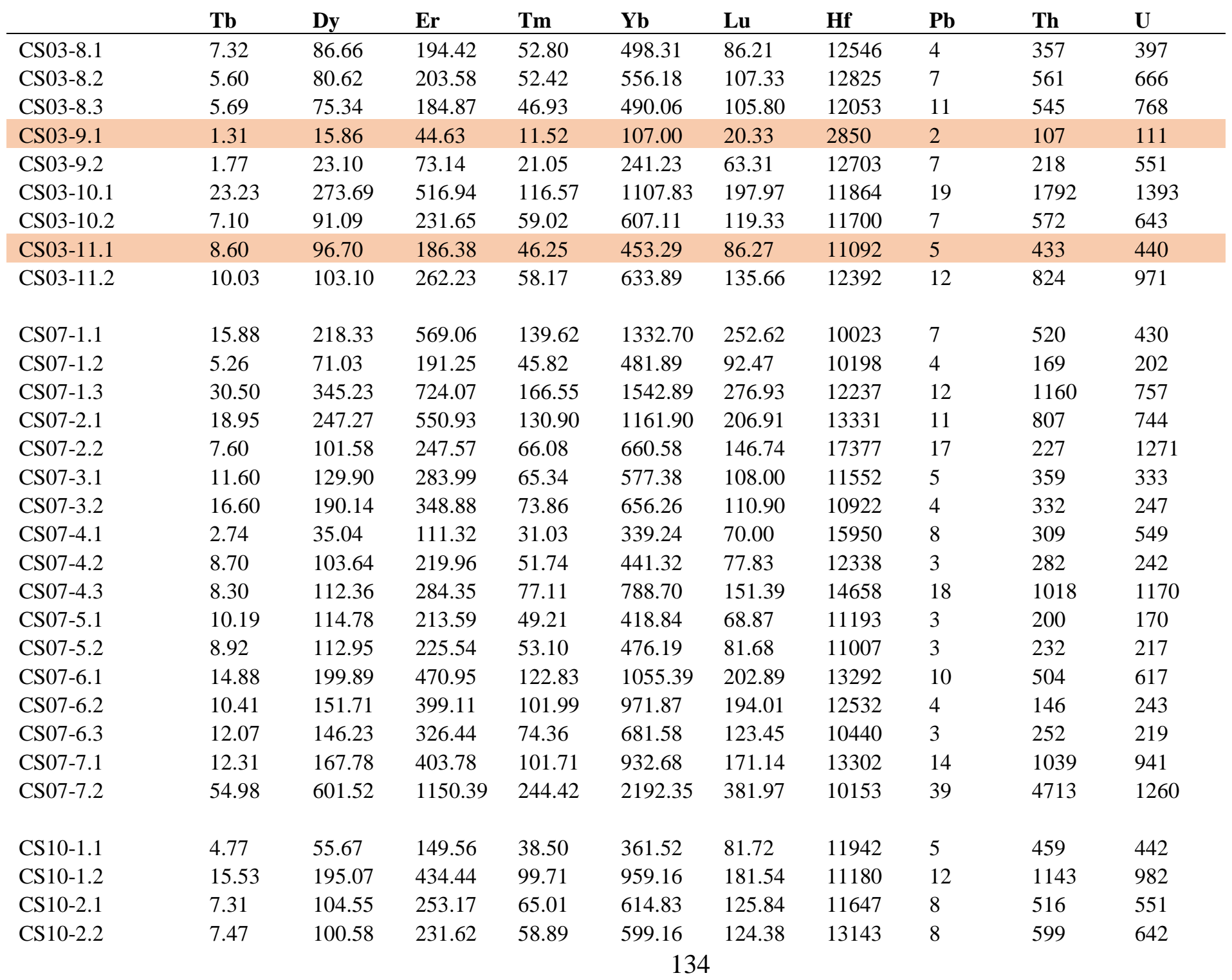




\begin{tabular}{|c|c|c|c|c|c|c|c|c|c|c|}
\hline & $\mathbf{T b}$ & Dy & Er & $\mathbf{T m}$ & $\mathbf{Y b}$ & Lu & Hf & $\mathbf{P b}$ & Th & $\mathbf{U}$ \\
\hline CS10-3.1 & 9.52 & 119.80 & 277.45 & 66.55 & 685.49 & 131.27 & 14032 & 18 & 1941 & 1571 \\
\hline CS10-3.2 & 4.37 & 54.56 & 153.98 & 38.60 & 436.77 & 94.60 & 12460 & 8 & 488 & 535 \\
\hline CS10-3.3 & 11.90 & 151.14 & 293.31 & 68.29 & 667.03 & 130.76 & 11278 & 9 & 1106 & 733 \\
\hline CS10-4.1 & 86.05 & 971.73 & 1800.24 & 382.51 & 3177.86 & 531.39 & 10302 & 38 & 7138 & 3002 \\
\hline CS10-4.2 & 1.75 & 20.24 & 65.75 & 24.50 & 284.08 & 80.77 & 13259 & 9 & 503 & 702 \\
\hline CS10-5.1 & 6.58 & 79.49 & 189.34 & 48.29 & 500.22 & 101.58 & 13008 & 7 & 649 & 645 \\
\hline CS10-5.2 & 7.58 & 93.70 & 198.29 & 48.92 & 465.30 & 97.40 & 11976 & 12 & 1281 & 868 \\
\hline CS10-7.1 & 9.97 & 125.61 & 245.56 & 58.18 & 582.78 & 121.13 & 13043 & 13 & 912 & 923 \\
\hline CS10-7.2 & 7.68 & 91.88 & 245.98 & 62.35 & 645.96 & 131.95 & 12864 & 8 & 693 & 672 \\
\hline CS10-8.1 & 56.35 & 590.00 & 1025.73 & 223.97 & 1897.47 & 311.30 & 9717 & 23 & 4994 & 1748 \\
\hline CS10-8.2 & 4.34 & 62.84 & 124.27 & 26.24 & 255.46 & 46.15 & 12801 & 5 & 644 & 468 \\
\hline CS10-10.1 & 11.65 & 139.33 & 291.13 & 66.32 & 651.33 & 121.78 & 10404 & 9 & 1074 & 762 \\
\hline CS10-10.2 & 7.02 & 95.02 & 197.65 & 47.10 & 433.33 & 89.67 & 12836 & 9 & 961 & 702 \\
\hline CS13-1.1 & 10.18 & 137.00 & 396.71 & 96.36 & 928.67 & 174.00 & 11563 & 8 & 471 & 606 \\
\hline CS13-1.2 & 6.23 & 77.52 & 184.05 & 45.16 & 494.50 & 96.30 & 11912 & 10 & 515 & 607 \\
\hline CS13-2.1 & 33.51 & 341.15 & 649.36 & 151.30 & 1275.89 & 219.84 & 10051 & 8 & 908 & 559 \\
\hline CS13-2.2 & 16.69 & 207.66 & 486.80 & 122.94 & 1176.77 & 214.36 & 10316 & 8 & 590 & 560 \\
\hline CS13-3.1 & 9.31 & 121.03 & 303.69 & 83.39 & 810.67 & 165.27 & 11122 & 21 & 931 & 1544 \\
\hline CS13-4.1 & 5.38 & 66.35 & 118.21 & 23.74 & 219.22 & 36.72 & 9393 & 1 & 55 & 57 \\
\hline CS13-4.2 & 17.69 & 196.76 & 370.62 & 75.48 & 639.83 & 104.35 & 10240 & 5 & 344 & 318 \\
\hline CS13-5.1 & 13.18 & 172.18 & 367.96 & 85.96 & 799.96 & 147.68 & 12857 & 21 & 954 & 1242 \\
\hline CS13-5.2 & 33.14 & 352.14 & 627.03 & 137.25 & 1163.58 & 200.64 & 12295 & 17 & 1176 & 1373 \\
\hline CS13-5.3 & 10.28 & 105.83 & 234.30 & 58.36 & 509.38 & 103.35 & 12895 & 8 & 569 & 814 \\
\hline CS13-6.1 & 9.24 & 109.68 & 269.98 & 63.70 & 638.01 & 126.98 & 13333 & 13 & 633 & 885 \\
\hline CS13-6.2 & 10.82 & 130.20 & 327.06 & 81.81 & 699.06 & 133.32 & 12616 & 7 & 385 & 575 \\
\hline CS13-7.1 & 10.80 & 136.41 & 299.34 & 68.74 & 703.07 & 126.05 & 11822 & 10 & 696 & 628 \\
\hline CS13-7.2 & 6.64 & 84.39 & 190.06 & 48.27 & 463.58 & 93.48 & 14646 & 26 & 506 & 1611 \\
\hline CS13-9.1 & 11.36 & 131.25 & 267.99 & 56.98 & 567.72 & 107.98 & 11742 & 12 & 802 & 855 \\
\hline CS13-9.2 & 6.83 & 85.66 & 181.20 & 50.49 & 474.76 & 103.55 & 14413 & 13 & 555 & 1064 \\
\hline CS19-1.1 & 7.70 & 92.00 & 195.97 & 47.21 & 427.52 & 83.96 & 12478 & 4 & 433 & 308 \\
\hline
\end{tabular}




\begin{tabular}{|c|c|c|c|c|c|c|c|c|c|c|}
\hline & $\mathbf{T b}$ & Dy & $\mathbf{E r}$ & $\mathbf{T m}$ & $\mathbf{Y b}$ & Lu & Hf & $\mathbf{P b}$ & Th & $\mathbf{U}$ \\
\hline CS19-2.1 & 26.78 & 277.79 & 441.19 & 91.78 & 826.22 & 139.48 & 9562 & 16 & 5295 & 1093 \\
\hline CS19-2.2 & 32.39 & 313.68 & 432.23 & 92.16 & 732.25 & 123.34 & 11821 & 17 & 6315 & 1136 \\
\hline CS19-3.1 & 2.79 & 37.48 & 86.44 & 24.23 & 243.12 & 47.94 & 11667 & 1 & 69 & 120 \\
\hline CS19-3.2 & 11.04 & 137.36 & 361.53 & 92.58 & 891.40 & 170.48 & 13476 & 8 & 595 & 689 \\
\hline CS19-4.1 & 3.89 & 43.96 & 105.36 & 28.51 & 282.90 & 59.71 & 13428 & 6 & 234 & 417 \\
\hline CS19-4.2 & 85.71 & 879.85 & 1456.37 & 318.23 & 2663.68 & 466.21 & 8507 & 26 & 8513 & 1860 \\
\hline CS19-5.1 & 8.60 & 102.47 & 248.31 & 67.18 & 605.54 & 124.89 & 8162 & 5 & 840 & 523 \\
\hline CS19-5.2 & 60.05 & 495.49 & 563.49 & 117.42 & 911.74 & 164.02 & 9455 & 12 & 7872 & 1091 \\
\hline CS19-6.1 & 34.14 & 340.78 & 559.30 & 114.60 & 882.94 & 144.23 & 10160 & 9 & 1618 & 555 \\
\hline CS19-6.2 & 59.26 & 605.11 & 892.59 & 182.37 & 1549.47 & 259.13 & 9565 & 19 & 4575 & 1378 \\
\hline CS19-7.1 & 7.18 & 68.98 & 147.13 & 34.86 & 335.83 & 71.96 & 12141 & 10 & 766 & 802 \\
\hline CS19-7.2 & 13.63 & 122.94 & 187.49 & 45.62 & 375.98 & 73.03 & 8324 & 10 & 3057 & 690 \\
\hline CS25-1.1 & 19.66 & 227.08 & 457.87 & 108.56 & 1045.90 & 195.64 & 11810 & 14 & 1333 & 1111 \\
\hline CS25-1.2 & 8.26 & 100.09 & 255.53 & 64.16 & 606.10 & 120.27 & 14133 & 15 & 863 & 960 \\
\hline CS25-2.1 & 15.89 & 196.61 & 477.27 & 126.27 & 1214.79 & 233.15 & 13172 & 32 & 1531 & 2101 \\
\hline CS25-2.2 & 13.71 & 145.13 & 314.18 & 70.82 & 668.78 & 117.18 & 12057 & 6 & 515 & 390 \\
\hline CS25-3.1 & 15.20 & 172.00 & 355.00 & 75.95 & 679.27 & 114.82 & 11233 & 6 & 429 & 469 \\
\hline CS25-3.2 & 3.03 & 34.70 & 84.72 & 24.06 & 216.04 & 40.28 & 13208 & 3 & 149 & 220 \\
\hline CS25-4.1 & 8.92 & 128.72 & 303.39 & 74.17 & 751.38 & 145.77 & 12799 & 13 & 770 & 930 \\
\hline CS25-4.2 & 8.79 & 109.15 & 241.89 & 61.05 & 564.70 & 110.39 & 11671 & 6 & 390 & 527 \\
\hline CS25-4.3 & 9.04 & 120.40 & 321.86 & 75.93 & 797.67 & 152.84 & 15286 & 11 & 759 & 941 \\
\hline CS25-6.1 & 5.87 & 83.62 & 200.85 & 49.23 & 518.67 & 97.86 & 13399 & 8 & 391 & 659 \\
\hline CS25-6.2 & 9.42 & 95.40 & 203.04 & 57.89 & 551.97 & 103.93 & 15122 & 8 & 547 & 633 \\
\hline CS25-7.1 & 19.25 & 215.42 & 416.24 & 97.43 & 877.42 & 151.33 & 11789 & 8 & 847 & 584 \\
\hline CS25-7.2 & 2.63 & 34.41 & 105.05 & 33.79 & 411.05 & 119.17 & 20842 & 22 & 816 & 1912 \\
\hline CS25-8.1 & 7.21 & 83.08 & 201.11 & 52.16 & 519.34 & 102.83 & 13317 & 7 & 466 & 516 \\
\hline CS25-8.2 & 10.65 & 134.43 & 297.50 & 76.53 & 741.36 & 140.29 & 13020 & 10 & 650 & 770 \\
\hline CS25-8.3 & 6.81 & 96.42 & 231.76 & 61.27 & 603.81 & 116.07 & 12740 & 9 & 628 & 691 \\
\hline 11SN34-1.1 & 15.64 & 176.15 & 384.02 & 85.87 & 850.01 & 151.23 & 10214 & 5 & 402 & 281 \\
\hline 11SN34-1.2 & 15.52 & 191.44 & 493.40 & 122.19 & 1214.53 & 232.20 & 11118 & 9 & 738 & 739 \\
\hline
\end{tabular}




\begin{tabular}{|c|c|c|c|c|c|c|c|c|c|c|}
\hline & $\mathbf{T b}$ & Dy & Er & $\mathbf{T m}$ & $\mathbf{Y b}$ & Lu & Hf & $\mathbf{P b}$ & Th & $\mathbf{U}$ \\
\hline 11SN34-2.1 & 4.72 & 70.24 & 182.93 & 46.14 & 466.17 & 91.09 & 10714 & 2 & 279 & 238 \\
\hline $11 \mathrm{SN} 34-2.2$ & 11.41 & 166.30 & 423.16 & 104.75 & 1001.67 & 188.18 & 12447 & 7 & 537 & 588 \\
\hline 11SN34-3.1 & 65.90 & 831.90 & 2000.03 & 484.63 & 4494.80 & 815.04 & 18456 & 101 & 8739 & 7239 \\
\hline $11 \mathrm{SN} 34-3.2$ & 2.02 & 31.85 & 126.90 & 43.94 & 554.15 & 133.68 & 15743 & 14 & 189 & 1201 \\
\hline 11SN34-4.1 & 51.84 & 655.56 & 1267.71 & 271.65 & 2236.09 & 378.16 & 13259 & 15 & 1499 & 970 \\
\hline $11 \mathrm{SN} 34-4.2$ & 13.56 & 182.80 & 378.67 & 87.70 & 761.04 & 132.88 & 11241 & 4 & 263 & 238 \\
\hline 11SN34-5.1 & 6.49 & 81.78 & 220.00 & 56.26 & 562.48 & 108.56 & 11702 & 4 & 225 & 232 \\
\hline 11SN34-5.2 & 18.54 & 239.94 & 633.16 & 147.68 & 1355.70 & 254.31 & 11502 & 15 & 934 & 913 \\
\hline 11SN34-6.1 & 1.39 & 19.09 & 74.47 & 19.18 & 210.01 & 45.48 & 7509 & 4 & 98 & 219 \\
\hline 11SN34-6.2 & 8.50 & 107.96 & 272.25 & 71.51 & 712.75 & 134.48 & 11915 & 5 & 307 & 364 \\
\hline $11 \mathrm{SN} 34-6.3$ & 42.34 & 562.64 & 1508.79 & 368.90 & 3601.78 & 631.58 & 20335 & 75 & 3940 & 5476 \\
\hline 11SN34-7.1 & 14.28 & 188.84 & 527.83 & 136.68 & 1307.34 & 248.52 & 12785 & 17 & 802 & 1133 \\
\hline 11SN34-7.2 & 9.48 & 120.64 & 302.39 & 77.69 & 757.04 & 143.43 & 11041 & 4 & 266 & 279 \\
\hline 11SN34-8.1 & 9.31 & 117.74 & 311.67 & 74.14 & 724.96 & 139.91 & 13990 & 6 & 410 & 517 \\
\hline $11 \mathrm{SN} 34-8.2$ & 34.75 & 425.33 & 918.18 & 211.66 & 1993.12 & 356.94 & 9639 & 19 & 2120 & 1298 \\
\hline 11SN35-1.1 & 15.81 & 181.48 & 459.32 & 117.68 & 1226.69 & 242.37 & 14979 & 34 & 1468 & 2292 \\
\hline 11SN35-1.2 & 8.83 & 107.32 & 262.47 & 69.34 & 701.06 & 139.54 & 11918 & 13 & 871 & 963 \\
\hline 11SN35-2.1 & 2.95 & 40.95 & 96.63 & 23.32 & 225.28 & 42.95 & 12626 & 5 & 182 & 282 \\
\hline $11 \mathrm{SN} 35-2.2$ & 39.68 & 428.87 & 771.32 & 169.37 & 1406.28 & 245.54 & 10295 & 13 & 1225 & 956 \\
\hline 11SN35-3.1 & 8.55 & 99.04 & 243.55 & 64.41 & 624.14 & 115.48 & 13230 & 15 & 1074 & 1214 \\
\hline $11 \mathrm{SN} 35-3.2$ & 15.88 & 181.55 & 355.86 & 87.37 & 737.42 & 133.67 & 11806 & 9 & 756 & 688 \\
\hline 11SN35-4.1 & 8.81 & 102.19 & 241.43 & 60.04 & 558.89 & 106.61 & 14080 & 14 & 813 & 1021 \\
\hline $11 \mathrm{SN} 35-4.2$ & 18.67 & 211.13 & 434.63 & 100.63 & 790.79 & 139.02 & 10395 & 5 & 390 & 341 \\
\hline 11SN35-5.1 & 10.05 & 123.10 & 335.26 & 87.39 & 899.72 & 176.44 & 9964 & 10 & 622 & 677 \\
\hline $11 \mathrm{SN} 35-5.2$ & 20.07 & 235.99 & 522.93 & 125.06 & 1186.92 & 212.34 & 12187 & 26 & 1382 & 1884 \\
\hline 11SN35-6.1 & 9.23 & 116.44 & 269.08 & 65.81 & 650.63 & 119.46 & 13082 & 13 & 1001 & 1016 \\
\hline $11 \mathrm{SN} 35-6.2$ & 6.81 & 80.83 & 181.19 & 44.94 & 420.14 & 80.81 & 11420 & 5 & 316 & 412 \\
\hline $11 \mathrm{SN} 35-7.1$ & 8.92 & 111.20 & 235.95 & 61.93 & 559.81 & 114.15 & 11956 & 14 & 1136 & 970 \\
\hline $11 \mathrm{SN} 35-7.2$ & 12.92 & 141.74 & 334.09 & 82.52 & 785.45 & 145.92 & 13199 & 20 & 1489 & 1353 \\
\hline 11SN35-8.1 & 8.67 & 108.89 & 244.59 & 62.60 & 620.39 & 118.16 & 13778 & 9 & 746 & 823 \\
\hline $11 \mathrm{SN} 35-8.2$ & 8.31 & 95.62 & 209.26 & 54.04 & 521.04 & 95.39 & 12312 & 9 & 565 & 695 \\
\hline
\end{tabular}




\begin{tabular}{|c|c|c|c|c|c|c|c|c|c|c|}
\hline & $\mathbf{T b}$ & Dy & $\mathbf{E r}$ & $\mathbf{T m}$ & $\mathbf{Y b}$ & $\mathbf{L u}$ & Hf & $\mathbf{P b}$ & Th & $\mathbf{U}$ \\
\hline 11SN35-8.3 & 9.06 & 121.44 & 278.30 & 70.59 & 677.00 & 130.82 & 11738 & 9 & 699 & 672 \\
\hline 11SN36-1.1 & 6.73 & 77.77 & 201.51 & 50.84 & 563.79 & 121.37 & 11502 & 21 & 1363 & 1350 \\
\hline 11SN36-1.2 & 12.80 & 152.99 & 334.61 & 87.00 & 937.54 & 185.94 & 14513 & 93 & 9118 & 5829 \\
\hline $11 \mathrm{SN} 36-2.1$ & 23.05 & 287.22 & 594.31 & 134.45 & 1211.13 & 218.85 & 16320 & 19 & 758 & 1302 \\
\hline 11SN36-2.2 & 11.15 & 125.09 & 264.81 & 68.01 & 638.27 & 121.04 & 12252 & 15 & 1065 & 1071 \\
\hline 11SN36-3.1 & 4.71 & 60.37 & 152.28 & 40.04 & 444.86 & 94.56 & 12862 & 12 & 596 & 837 \\
\hline 11SN36-3.2 & 14.21 & 170.00 & 398.02 & 98.29 & 1029.43 & 209.54 & 14252 & 74 & 5102 & 4440 \\
\hline 11SN36-4.1 & 7.53 & 91.40 & 193.30 & 45.05 & 448.72 & 87.03 & 10821 & 1 & 134 & 146 \\
\hline 11SN36-4.2 & 19.56 & 243.05 & 511.30 & 117.13 & 1056.90 & 204.60 & 11215 & 8 & 771 & 596 \\
\hline 11SN36-5.1 & 5.80 & 71.50 & 198.93 & 52.26 & 518.90 & 99.63 & 13015 & 7 & 323 & 638 \\
\hline 11SN36-5.2 & 14.11 & 190.54 & 512.71 & 141.76 & 1462.80 & 308.36 & 14770 & 36 & 1189 & 2155 \\
\hline 11SN36-6.1 & 19.75 & 235.04 & 551.11 & 143.91 & 1488.66 & 308.07 & 13279 & 40 & 3174 & 2359 \\
\hline 11 SN36-6.2 & 7.42 & 64.91 & 112.71 & 26.74 & 267.99 & 50.87 & 10732 & 2 & 601 & 272 \\
\hline 11SN36-7.1 & 11.88 & 152.49 & 324.06 & 80.77 & 792.94 & 150.47 & 12325 & 13 & 1436 & 943 \\
\hline 11 SN36-7.2 & 46.18 & 377.19 & 613.88 & 150.02 & 1477.51 & 282.66 & 14996 & 90 & 9140 & 6192 \\
\hline 11SN36-8.1 & 9.21 & 109.45 & 204.14 & 49.86 & 490.84 & 93.40 & 11636 & 8 & 830 & 554 \\
\hline $11 \mathrm{SN} 36-8.2$ & 5.28 & 65.13 & 174.89 & 44.87 & 474.66 & 105.42 & 12208 & 13 & 933 & 1032 \\
\hline 11SN37-1.1 & 8.74 & 108.24 & 219.81 & 50.96 & 526.71 & 110.11 & 12273 & 41 & 4839 & 2946 \\
\hline 11SN37-1.2 & 8.32 & 95.07 & 229.32 & 58.77 & 625.19 & 127.60 & 12740 & 26 & 2434 & 1917 \\
\hline 11SN37-2.1 & 11.77 & 176.16 & 568.05 & 166.27 & 1902.46 & 418.75 & 15382 & 85 & 3250 & 5194 \\
\hline 11SN37-2.2 & 51.74 & 624.31 & 1155.19 & 251.96 & 2189.26 & 376.41 & 9391 & 68 & 12383 & 4870 \\
\hline 11SN37-3.1 & 5.91 & 79.59 & 204.29 & 55.18 & 635.48 & 147.97 & 14021 & 43 & 1391 & 2248 \\
\hline $11 \mathrm{SN} 37-3.2$ & 4.86 & 59.45 & 146.24 & 39.12 & 424.25 & 97.40 & 11523 & 13 & 631 & 819 \\
\hline 11 SN37-4.1 & 13.18 & 144.16 & 316.20 & 77.64 & 746.23 & 149.88 & 12611 & 11 & 1101 & 1013 \\
\hline 11 SN37-4.2 & 5.07 & 46.97 & 107.52 & 26.09 & 268.18 & 56.35 & 11572 & 7 & 2386 & 804 \\
\hline 11SN37-5.1 & 4.35 & 55.32 & 119.89 & 30.28 & 293.57 & 58.42 & 10781 & 8 & 657 & 565 \\
\hline 11SN37-5.2 & 32.20 & 366.77 & 663.82 & 153.91 & 1386.11 & 243.51 & 10443 & 25 & 2843 & 1527 \\
\hline 11SN37-6.1 & 2.78 & 37.64 & 92.43 & 27.06 & 272.22 & 61.86 & 12019 & 8 & 471 & 563 \\
\hline 11 SN37-6.2 & 2.24 & 32.05 & 95.65 & 26.18 & 302.12 & 73.27 & 13877 & 22 & 772 & 1158 \\
\hline
\end{tabular}




\begin{tabular}{|c|c|c|c|c|c|c|c|c|c|c|}
\hline & $\mathbf{T b}$ & Dy & $\mathbf{E r}$ & $\mathbf{T m}$ & $\mathbf{Y b}$ & Lu & Hf & $\mathbf{P b}$ & Th & $\mathbf{U}$ \\
\hline 11 SN37-7.1 & 7.31 & 93.54 & 229.57 & 59.83 & 633.63 & 130.81 & 10694 & 22 & 1393 & 1333 \\
\hline 11SN37-8.1 & 18.45 & 202.83 & 405.70 & 96.70 & 927.56 & 170.94 & 10820 & 21 & 2007 & 1300 \\
\hline 11SN38-1.1 & 28.91 & 355.76 & 664.75 & 154.98 & 1433.22 & 268.62 & 10866 & 43 & 2625 & 2367 \\
\hline 11SN38-2.1 & 6.44 & 78.19 & 202.78 & 50.32 & 544.43 & 109.80 & 10836 & 12 & 637 & 827 \\
\hline $11 \mathrm{SN} 38-2.2$ & 7.97 & 107.12 & 274.51 & 70.41 & 688.84 & 136.12 & 10981 & 16 & 807 & 905 \\
\hline 11SN38-3.1 & 2.43 & 30.34 & 80.23 & 23.51 & 220.90 & 46.98 & 11734 & 5 & 221 & 336 \\
\hline $11 \mathrm{SN} 38-3.2$ & 9.54 & 114.55 & 302.71 & 75.84 & 777.66 & 149.34 & 11294 & 15 & 859 & 951 \\
\hline 11SN38-4.1 & 4.22 & 45.15 & 110.02 & 25.43 & 298.49 & 61.97 & 12171 & 14 & 637 & 893 \\
\hline 11SN38-6.1 & 48.59 & 551.24 & 1025.28 & 225.91 & 2028.77 & 354.93 & 10667 & 49 & 5481 & 2991 \\
\hline 11SN38-6.2 & 7.50 & 84.62 & 204.38 & 49.43 & 540.57 & 103.84 & 11598 & 16 & 752 & 782 \\
\hline 11SN38-7.1 & 3.23 & 39.21 & 89.22 & 23.22 & 246.04 & 56.29 & 11749 & 9 & 494 & 895 \\
\hline $11 \mathrm{SN} 38-7.2$ & 3.64 & 41.31 & 101.34 & 25.11 & 271.81 & 55.75 & 9688 & 2 & 113 & 128 \\
\hline 11SN38-8.1 & 6.34 & 78.56 & 180.30 & 42.64 & 443.10 & 80.52 & 10928 & 11 & 687 & 646 \\
\hline $11 \mathrm{SN} 38-8.2$ & 17.94 & 233.37 & 544.59 & 124.52 & 1112.95 & 204.43 & 10762 & 10 & 549 & 597 \\
\hline $11 \mathrm{SN} 38-8.3$ & 3.10 & 46.49 & 117.76 & 30.56 & 319.06 & 63.72 & 12653 & 7 & 344 & 450 \\
\hline 11SN40-1.1 & 15.18 & 172.06 & 353.00 & 87.84 & 769.89 & 140.93 & 12670 & 12 & 845 & 772 \\
\hline 11SN40-1.2 & 9.75 & 123.94 & 334.14 & 88.35 & 943.42 & 187.16 & 14313 & 29 & 798 & 1887 \\
\hline
\end{tabular}




\begin{tabular}{|c|c|c|c|c|c|c|c|c|c|c|}
\hline & $\mathbf{T b}$ & Dy & Er & $\mathbf{T m}$ & $\mathbf{Y b}$ & $\mathbf{L u}$ & Hf & $\mathbf{P b}$ & Th & $\mathbf{U}$ \\
\hline 11SN40-5.1 & 2.78 & 33.43 & 97.54 & 29.79 & 262.29 & 53.16 & 11854 & 3 & 193 & 226 \\
\hline $11 \mathrm{SN} 40-5.2$ & 16.86 & 202.69 & 424.61 & 103.60 & 1027.54 & 197.72 & 14078 & 43 & 3044 & 2906 \\
\hline 11SN40-6.1 & 19.23 & 202.68 & 413.32 & 95.47 & 842.41 & 161.42 & 8509 & 2 & 195 & 121 \\
\hline 11 SN40-6.2 & 15.47 & 207.18 & 553.03 & 144.81 & 1434.68 & 281.27 & 14349 & 36 & 1698 & 2872 \\
\hline 11 SN40-7.1 & 17.15 & 235.37 & 481.86 & 111.15 & 1011.05 & 176.76 & 11820 & 9 & 800 & 700 \\
\hline 11SN40-7.2 & 7.52 & 102.33 & 248.91 & 63.79 & 610.33 & 122.32 & 12330 & 11 & 805 & 889 \\
\hline 11SN40-9.1 & 28.02 & 323.38 & 640.86 & 137.44 & 1205.66 & 202.23 & 12678 & 15 & 1286 & 838 \\
\hline 11SN40-9.2 & 4.99 & 60.03 & 199.15 & 57.95 & 649.82 & 156.59 & 16858 & 18 & 735 & 1815 \\
\hline 11SN40-10.1 & 10.13 & 135.41 & 524.73 & 153.50 & 1770.16 & 373.36 & 19117 & 62 & 1159 & 4354 \\
\hline $11 \mathrm{SN} 40-10.2$ & 26.79 & 285.68 & 481.77 & 105.18 & 949.54 & 158.44 & 10742 & 7 & 925 & 651 \\
\hline 11SN41-1.1 & 10.82 & 121.63 & 336.08 & 81.72 & 772.76 & 149.02 & 11472 & 14 & 1227 & 1127 \\
\hline 11SN41-1.2 & 7.30 & 90.59 & 230.83 & 62.81 & 609.72 & 117.91 & 12686 & 10 & 493 & 625 \\
\hline $11 \mathrm{SN} 41-2.1$ & 26.50 & 284.71 & 536.29 & 121.51 & 997.29 & 176.15 & 11603 & 8 & 1022 & 644 \\
\hline $11 \mathrm{SN} 41-2.2$ & 6.85 & 90.24 & 186.07 & 49.97 & 436.56 & 80.27 & 11874 & 5 & 386 & 422 \\
\hline 11SN41-3.1 & 47.88 & 572.06 & 1591.35 & 436.61 & 4648.67 & 951.17 & 16460 & 155 & 3960 & 9223 \\
\hline $11 \mathrm{SN} 41-3.2$ & 6.87 & 82.99 & 211.65 & 52.02 & 501.05 & 98.89 & 13765 & 7 & 1286 & 597 \\
\hline 11SN41-4.2 & 5.62 & 72.30 & 159.77 & 39.12 & 380.21 & 78.21 & 13037 & 4 & 322 & 373 \\
\hline 11 SN41-5.1 & 4.60 & 52.39 & 132.43 & 34.19 & 358.25 & 75.46 & 10372 & 6 & 316 & 402 \\
\hline $11 \mathrm{SN} 41-5.2$ & 12.04 & 145.34 & 315.22 & 71.16 & 586.62 & 113.72 & 11462 & 5 & 396 & 423 \\
\hline 11 SN41-7.1 & 7.47 & 102.35 & 197.41 & 47.90 & 491.48 & 90.87 & 12745 & 8 & 587 & 606 \\
\hline $11 \mathrm{SN} 41-7.2$ & 46.62 & 491.18 & 934.81 & 199.90 & 1735.45 & 298.49 & 10983 & 17 & 2167 & 1176 \\
\hline 11 SN41-8.1 & 6.11 & 72.34 & 189.35 & 49.41 & 429.98 & 85.76 & 14215 & 7 & 1903 & 722 \\
\hline $11 \mathrm{SN} 41-8.2$ & 24.61 & 250.95 & 458.95 & 98.63 & 929.40 & 155.48 & 9574 & 5 & 520 & 351 \\
\hline 11SN41-9.1 & 4.61 & 67.33 & 156.11 & 36.96 & 332.14 & 60.49 & 12549 & 3 & 189 & 227 \\
\hline $11 \mathrm{SN} 41-9.2$ & 7.58 & 89.12 & 212.46 & 57.30 & 535.53 & 106.12 & 12618 & 8 & 477 & 558 \\
\hline $11 \mathrm{SN} 41-10.1$ & 9.19 & 108.54 & 290.60 & 71.98 & 646.99 & 130.11 & 11328 & 8 & 480 & 591 \\
\hline $11 \mathrm{SN} 41-10.2$ & 9.58 & 132.25 & 316.23 & 75.45 & 707.72 & 128.27 & 14187 & 7 & 646 & 733 \\
\hline 11SN41-11.1 & 8.82 & 108.92 & 273.07 & 64.58 & 652.62 & 121.07 & 14574 & 7 & 565 & 698 \\
\hline $11 \mathrm{SN} 41-11.2$ & 4.95 & 63.60 & 159.44 & 41.32 & 433.66 & 88.42 & 12994 & 6 & 397 & 492 \\
\hline $11 \mathrm{SN} 41-11.3$ & 8.36 & 93.62 & 219.74 & 57.41 & 507.38 & 99.00 & 12579 & 7 & 476 & 553 \\
\hline
\end{tabular}


APPENDIX F: O Isotope Data

\begin{tabular}{|c|c|c|c|c|c|c|c|c|c|}
\hline Spot Number & $\begin{array}{l}\delta^{18} O \% \\
\text { VSMOW } \\
\end{array}$ & $\begin{array}{l}\text { 2SD } \\
\text { (ext.) }\end{array}$ & $\begin{array}{l}\text { Mass Bias } \\
(\%)\end{array}$ & $\begin{array}{l}\delta^{18} \mathrm{O} \% \\
\text { measured }\end{array}$ & $\begin{array}{l}\text { 2SE } \\
\text { (int.) }\end{array}$ & ${ }^{16} \mathrm{O}$ (Gcps) & IP (nA) & $\begin{array}{l}\text { Yield } \\
(\text { Gcps/nA })\end{array}$ & ${ }^{16} \mathrm{OH} /{ }^{16} \mathrm{O}$ \\
\hline MC44 $91500 \mathrm{~g} 2$ & & & & 10.283 & 0.23 & 2.6367 & 1.8611 & 1.4167 & $1.2991 \mathrm{E}-03$ \\
\hline MC44 91500 g3 & & & & 10.177 & 0.28 & 2.6417 & 1.8637 & 1.4175 & $1.3077 \mathrm{E}-03$ \\
\hline MC44 91500 g4 & & & & 10.121 & 0.21 & 2.6438 & 1.8639 & 1.4184 & $1.3042 \mathrm{E}-03$ \\
\hline MC44 91500 g5 & & & & 10.343 & 0.26 & 2.6335 & 1.8615 & 1.4147 & $1.3152 \mathrm{E}-03$ \\
\hline average and $2 \mathrm{SD}$ & 10.07 & & 0.15939 & 10.231 & 0.20 & & & & \\
\hline MC44 11SN34_1.1 & 5.83 & 0.16 & & 5.965 & 0.22 & 2.6042 & 1.8528 & 1.4055 & $1.3635 \mathrm{E}-03$ \\
\hline MC44 11SN34_1.2 & 5.83 & 0.16 & & 5.968 & 0.19 & 2.5887 & 1.8437 & 1.4041 & $1.4695 \mathrm{E}-03$ \\
\hline MC44 11SN34_2.1 & 5.73 & 0.16 & & 5.865 & 0.17 & 2.5697 & 1.8307 & 1.4037 & $1.3896 \mathrm{E}-03$ \\
\hline MC44 11SN34_2.2 & 5.79 & 0.16 & & 5.932 & 0.22 & 2.5434 & 1.8201 & 1.3974 & $1.4748 \mathrm{E}-03$ \\
\hline MC44 11SN34_3.1 & 5.70 & 0.16 & & 5.836 & 0.22 & 2.5343 & 1.8082 & 1.4015 & $1.4918 \mathrm{E}-03$ \\
\hline MC44 11SN34_3.2 & 5.46 & 0.16 & & 5.596 & 0.17 & 2.5079 & 1.7987 & 1.3943 & $1.5035 \mathrm{E}-03$ \\
\hline MC44 11SN34_4.1 & 5.79 & 0.16 & & 5.924 & 0.18 & 2.4723 & 1.7817 & 1.3876 & $1.4876 \mathrm{E}-03$ \\
\hline MC44 11SN34_4.2 & 6.00 & 0.16 & & 6.133 & 0.18 & 2.4602 & 1.7680 & 1.3915 & $1.5807 \mathrm{E}-03$ \\
\hline MC44 11SN34_5.1 & 5.54 & 0.16 & & 5.674 & 0.21 & 2.6238 & 1.8609 & 1.4100 & $1.4670 \mathrm{E}-03$ \\
\hline MC44 11SN34_5.2 & 5.68 & 0.16 & & 5.822 & 0.24 & 2.6348 & 1.8687 & 1.4100 & $1.4633 \mathrm{E}-03$ \\
\hline MC44 91500 g2.1 & & & & 10.235 & 0.26 & 2.6319 & 1.8675 & 1.4094 & $1.4987 \mathrm{E}-03$ \\
\hline MC44 91500 g3.1 & & & & 10.124 & 0.28 & 2.6358 & 1.8661 & 1.4125 & $1.5071 \mathrm{E}-03$ \\
\hline MC44 $91500 \mathrm{~g} 4.1$ & & & & 10.153 & 0.17 & 2.6285 & 1.8607 & 1.4127 & $1.4985 \mathrm{E}-03$ \\
\hline MC44 91500 g5.1 & & & & 10.228 & 0.19 & 2.6137 & 1.8579 & 1.4068 & $1.5186 \mathrm{E}-03$ \\
\hline average and $2 \mathrm{SD}$ & & & & 10.185 & 0.11 & & & & \\
\hline bracket average and 2SD & 10.07 & & 0.13662 & 10.208 & 0.16 & & & & \\
\hline MC44 11SN36_8.1 & 6.15 & 0.18 & & 6.189 & 0.24 & 2.5957 & 1.8454 & 1.4066 & $1.6188 \mathrm{E}-03$ \\
\hline MC44 11SN36_8.2 & 6.25 & 0.18 & & 6.292 & 0.24 & 2.5846 & 1.8393 & 1.4053 & $1.5796 \mathrm{E}-03$ \\
\hline MC44 11SN36_6.1 & 6.59 & 0.18 & & 6.625 & 0.22 & 2.5548 & 1.8273 & 1.3981 & $1.5972 \mathrm{E}-03$ \\
\hline MC44 11SN36_6.2 & 6.22 & 0.18 & & 6.264 & 0.25 & 2.5518 & 1.8191 & 1.4028 & $1.6143 \mathrm{E}-03$ \\
\hline MC44 11SN36_4.1 & 6.96 & 0.18 & & 6.998 & 0.19 & 2.5370 & 1.8106 & 1.4012 & $1.6638 \mathrm{E}-03$ \\
\hline
\end{tabular}




\begin{tabular}{|c|c|c|c|c|c|c|c|c|c|}
\hline Spot Number & $\begin{array}{l}\delta^{18} O \quad \% \\
\text { VSMOW } \\
\end{array}$ & $\begin{array}{l}\text { 2SD } \\
\text { (ext.) }\end{array}$ & $\begin{array}{l}\text { Mass Bias } \\
\text { (\%o) }\end{array}$ & $\begin{array}{l}\delta^{18} \mathrm{O} \% \\
\text { measured }\end{array}$ & $\begin{array}{l}\text { 2SE } \\
\text { (int.) }\end{array}$ & ${ }^{16} \mathrm{O}$ (Gcps) & IP (nA) & $\begin{array}{l}\text { Yield } \\
\text { (Gcps/nA) }\end{array}$ & ${ }^{16} \mathrm{OH} /{ }^{16} \mathrm{O}$ \\
\hline MC44 11SN36_4.2 & 6.83 & 0.18 & & 6.872 & 0.22 & 2.5150 & 1.8010 & 1.3965 & $1.6451 \mathrm{E}-03$ \\
\hline MC44 11SN36_3.1 & 6.31 & 0.18 & & 6.347 & 0.24 & 2.5031 & 1.7898 & 1.3985 & $1.6183 \mathrm{E}-03$ \\
\hline MC44 11SN36_3.2 & 6.18 & 0.18 & & 6.220 & 0.25 & 2.4879 & 1.7816 & 1.3964 & $1.7404 \mathrm{E}-03$ \\
\hline MC44 11SN36_2.1 & 5.87 & 0.18 & & 5.905 & 0.22 & 2.4609 & 1.7687 & 1.3913 & $1.7346 \mathrm{E}-03$ \\
\hline MC44 11SN36_2.2 & 5.77 & 0.18 & & 5.810 & 0.27 & 2.6153 & 1.8640 & 1.4031 & $1.6125 \mathrm{E}-03$ \\
\hline MC44 91500 g2.2 & & & & 10.073 & 0.26 & 2.6403 & 1.8737 & 1.4091 & $1.5670 \mathrm{E}-03$ \\
\hline MC44 $91500 \mathrm{~g} 3.2$ & & & & 10.001 & 0.19 & 2.6490 & 1.8751 & 1.4127 & $1.5662 \mathrm{E}-03$ \\
\hline MC44 $91500 \mathrm{~g} 4.2$ & & & & 10.046 & 0.22 & 2.6390 & 1.8739 & 1.4083 & $1.5872 \mathrm{E}-03$ \\
\hline MC44 91500 g5.2 & & & & 10.017 & 0.20 & 2.6430 & 1.8723 & 1.4116 & $1.5547 \mathrm{E}-03$ \\
\hline average and $2 \mathrm{SD}$ & & & & 10.034 & 0.06 & & & & \\
\hline bracket average and $2 \mathrm{SD}$ & 10.07 & & 0.03923 & 10.110 & 0.18 & & & & \\
\hline MC44 CS07_7.1 & 5.90 & 0.40 & & 6.042 & 0.22 & 2.6247 & 1.8667 & 1.4061 & $1.6358 \mathrm{E}-03$ \\
\hline MC44 CS07_7.2 & 5.87 & 0.40 & & 6.014 & 0.17 & 2.6269 & 1.8642 & 1.4091 & $1.7278 \mathrm{E}-03$ \\
\hline MC44 CS07_6.1 & 5.64 & 0.40 & & 5.787 & 0.18 & 2.6217 & 1.8600 & 1.4095 & $1.6639 \mathrm{E}-03$ \\
\hline MC44 CS07_6.2 & 6.74 & 0.40 & & 6.882 & 0.20 & 2.6087 & 1.8562 & 1.4054 & $1.6665 \mathrm{E}-03$ \\
\hline MC44 CS07_6.3 & 6.38 & 0.40 & & 6.526 & 0.22 & 2.6023 & 1.8516 & 1.4054 & $1.7753 \mathrm{E}-03$ \\
\hline MC44 CS07_5.1 & 7.03 & 0.40 & & 7.169 & 0.26 & 2.5874 & 1.8440 & 1.4032 & $1.6808 \mathrm{E}-03$ \\
\hline MC44 CS07_5.2 & 7.32 & 0.40 & & 7.460 & 0.24 & 2.5742 & 1.8370 & 1.4013 & $1.6691 \mathrm{E}-03$ \\
\hline MC44 CS07_2.1 & 5.80 & 0.40 & & 5.946 & 0.18 & 2.5490 & 1.8258 & 1.3961 & $1.7236 \mathrm{E}-03$ \\
\hline MC44 CS07_2.2 & 6.18 & 0.40 & & 6.327 & 0.18 & 2.5483 & 1.8176 & 1.4020 & $1.7413 \mathrm{E}-03$ \\
\hline MC44 11SN37_3.1 & 6.38 & 0.40 & & 6.520 & 0.22 & 2.5209 & 1.8034 & 1.3979 & $1.7437 \mathrm{E}-03$ \\
\hline MC44 11SN37_3.2 & 6.05 & 0.40 & & 6.191 & 0.19 & 2.5226 & 1.7939 & 1.4062 & $1.9359 \mathrm{E}-03$ \\
\hline MC44 11SN37_4.1 & 6.56 & 0.40 & & 6.705 & 0.16 & 2.4920 & 1.7829 & 1.3977 & $1.7356 \mathrm{E}-03$ \\
\hline MC44 11SN37_4.2 & 6.40 & 0.40 & & 6.544 & 0.21 & 2.4662 & 1.7727 & 1.3912 & $1.7448 \mathrm{E}-03$ \\
\hline MC44 91500 g2.3 & & & & 10.516 & 0.29 & 2.6144 & 1.8701 & 1.3980 & $1.6781 \mathrm{E}-03$ \\
\hline MC44 91500 g3.3 & & & & 10.240 & 0.29 & 2.6488 & 1.8785 & 1.4101 & $1.6353 \mathrm{E}-03$ \\
\hline MC44 91500 g4.3 & & & & 10.240 & 0.22 & 2.6583 & 1.8801 & 1.4139 & $1.6130 \mathrm{E}-03$ \\
\hline
\end{tabular}




\begin{tabular}{|c|c|c|c|c|c|c|c|c|c|}
\hline Spot Number & $\begin{array}{l}\delta^{18} \mathrm{O} \% \text { } \\
\text { VSMOW } \\
\end{array}$ & $\begin{array}{l}\text { 2SD } \\
\text { (ext.) }\end{array}$ & $\begin{array}{l}\text { Mass Bias } \\
(\%)\end{array}$ & $\begin{array}{l}\delta^{18} \mathrm{O} \% \\
\text { measured } \\
\end{array}$ & $\begin{array}{l}\text { 2SE } \\
\text { (int.) }\end{array}$ & ${ }^{16} \mathrm{O}$ (Gcps) & IP $(\mathbf{n A})$ & $\begin{array}{l}\text { Yield } \\
(\text { Gcps/nA) }\end{array}$ & ${ }^{16} \mathrm{OH} /{ }^{16} \mathrm{O}$ \\
\hline MC44 91500 g4.4 & & & & 10.518 & 0.24 & 2.6547 & 1.8778 & 1.4137 & $1.6098 \mathrm{E}-03$ \\
\hline MC44 91500 g5.3 & & & & 10.274 & 0.23 & 2.6564 & 1.8767 & 1.4155 & $1.5963 \mathrm{E}-03$ \\
\hline average and $2 \mathrm{SD}$ & & & & 10.358 & 0.29 & & & & \\
\hline bracket average and 2SD & 10.07 & & 0.14245 & 10.214 & 0.40 & & & & \\
\hline MC44 11SN37_5.1 & 6.34 & 0.26 & & 6.584 & 0.21 & 2.6241 & 1.8711 & 1.4024 & $1.7057 \mathrm{E}-03$ \\
\hline MC44 11SN37_5.2 & 6.14 & 0.26 & & 6.387 & 0.22 & 2.6281 & 1.8669 & 1.4078 & 1.6969E-03 \\
\hline MC44 11SN37_6.1 & 5.96 & 0.26 & & 6.210 & 0.21 & 2.6390 & 1.8638 & 1.4159 & $1.6506 \mathrm{E}-03$ \\
\hline MC44 11SN37_6.2 & 5.34 & 0.26 & & 5.590 & 0.23 & 2.6528 & 1.8604 & 1.4259 & 1.8973E-03 \\
\hline MC44 11SN38_8.1 & 6.40 & 0.26 & & 6.644 & 0.16 & 2.6071 & 1.8506 & 1.4088 & $1.6303 \mathrm{E}-03$ \\
\hline MC44 11SN38_8.2 & 5.97 & 0.26 & & 6.217 & 0.25 & 2.5868 & 1.8435 & 1.4032 & 1.6239E-03 \\
\hline MC44 11SN38_7.1 & 6.62 & 0.26 & & 6.867 & 0.28 & 2.5712 & 1.8350 & 1.4012 & $1.6451 \mathrm{E}-03$ \\
\hline MC44 11SN38_7.2 & 6.24 & 0.26 & & 6.484 & 0.24 & 2.5762 & 1.8271 & 1.4100 & $1.7158 \mathrm{E}-03$ \\
\hline MC44 11SN38_2.1 & 6.35 & 0.26 & & 6.595 & 0.19 & 2.5682 & 1.8156 & 1.4145 & $1.7791 \mathrm{E}-03$ \\
\hline MC44 11SN38_2.2 & 6.30 & 0.26 & & 6.544 & 0.19 & 2.5307 & 1.8104 & 1.3979 & 1.6677E-03 \\
\hline MC44 11SN38_1.1 & 6.48 & 0.26 & & 6.728 & 0.26 & 2.5051 & 1.8012 & 1.3908 & $1.7217 \mathrm{E}-03$ \\
\hline MC44 11SN38_1.2 & 6.31 & 0.26 & & 6.559 & 0.24 & 2.4839 & 1.7936 & 1.3848 & 1.6640E-03 \\
\hline MC44 91500 g2.4 & & & & 10.369 & 0.20 & 2.4737 & 1.7801 & 1.3897 & $1.6984 \mathrm{E}-03$ \\
\hline MC44 91500 g3.4 & & & & 10.233 & 0.19 & 2.4521 & 1.7679 & 1.3870 & $1.6860 \mathrm{E}-03$ \\
\hline MC44 91500 g4.5 & & & & 10.318 & 0.21 & 2.6104 & 1.8683 & 1.3972 & $1.6271 \mathrm{E}-03$ \\
\hline MC44 91500 g5.4 & & & & 10.143 & 0.23 & 2.6536 & 1.8812 & 1.4106 & 1.5994E-03 \\
\hline average and $2 \mathrm{SD}$ & & & & 10.266 & 0.20 & & & & \\
\hline bracket average and 2SD & 10.07 & & 0.24432 & 10.317 & 0.26 & & & & \\
\hline MC45 91500 g2.1 & & & & 10.278 & 0.22 & 2.6499 & 1.8814 & 1.4085 & 1.4593E-03 \\
\hline MC45 91500 g3.1 & & & & 10.299 & 0.24 & 2.6600 & 1.8802 & 1.4147 & $1.4635 \mathrm{E}-03$ \\
\hline MC45 $91500 \mathrm{~g} 4.1$ & & & & 10.148 & 0.20 & 2.6604 & 1.8768 & 1.4175 & $1.4688 \mathrm{E}-03$ \\
\hline MC45 91500 g5.1 & & & & 10.152 & 0.19 & 2.6551 & 1.8750 & 1.4161 & $1.4865 \mathrm{E}-03$ \\
\hline average and $2 \mathrm{SD}$ & 10.07 & & 0.14776 & 10.219 & 0.16 & & & & \\
\hline
\end{tabular}




\begin{tabular}{|c|c|c|c|c|c|c|c|c|c|}
\hline Spot Number & $\begin{array}{l}\delta^{18} \mathrm{O} \% \\
\text { VSMOW } \\
\end{array}$ & $\begin{array}{l}\text { 2SD } \\
(\text { ext. })\end{array}$ & $\begin{array}{l}\text { Mass Bias } \\
(\%)\end{array}$ & $\begin{array}{l}\delta^{18} \mathrm{O} \% \\
\text { measured }\end{array}$ & $\begin{array}{l}\text { 2SE } \\
\text { (int.) }\end{array}$ & ${ }^{16} \mathrm{O}$ (Gcps) & IP (nA) & $\begin{array}{l}\text { Yield } \\
(\text { Gcps/nA })\end{array}$ & ${ }^{16} \mathrm{OH} /{ }^{16} \mathrm{O}$ \\
\hline MC45 11SN40_9.1 & 6.20 & 0.21 & & 6.399 & 0.14 & 2.6215 & 1.8687 & 1.4029 & $1.4889 \mathrm{E}-03$ \\
\hline MC45 11SN40_9.2 & 7.10 & 0.21 & & 7.300 & 0.20 & 2.6196 & 1.8654 & 1.4043 & $1.5144 \mathrm{E}-03$ \\
\hline MC45 11SN40_6.2 & 7.31 & 0.21 & & 7.513 & 0.23 & 2.6224 & 1.8587 & 1.4108 & $1.6042 \mathrm{E}-03$ \\
\hline MC45 11SN40_6.1 & 6.21 & 0.21 & & 6.416 & 0.25 & 2.6375 & 1.8536 & 1.4229 & $1.8100 \mathrm{E}-03$ \\
\hline MC45 11SN40_3.1 & 6.57 & 0.21 & & 6.773 & 0.19 & 2.6213 & 1.8464 & 1.4197 & $1.6849 \mathrm{E}-03$ \\
\hline MC45 11SN40_3.2 & 7.36 & 0.21 & & 7.563 & 0.23 & 2.5939 & 1.8389 & 1.4106 & $1.5259 \mathrm{E}-03$ \\
\hline MC45 11SN40_1.1 & 7.85 & 0.21 & & 8.049 & 0.21 & 2.5751 & 1.8308 & 1.4066 & $1.5111 \mathrm{E}-03$ \\
\hline MC45 11SN40_1.2 & 6.68 & 0.21 & & 6.881 & 0.22 & 2.5646 & 1.8243 & 1.4058 & $1.5673 \mathrm{E}-03$ \\
\hline MC45 11SN40_4.1 & 6.70 & 0.21 & & 6.900 & 0.28 & 2.5382 & 1.8122 & 1.4007 & $1.7070 \mathrm{E}-03$ \\
\hline MC45 11SN40_4.2 & 6.61 & 0.21 & & 6.814 & 0.19 & 2.5206 & 1.8027 & 1.3982 & $1.6038 \mathrm{E}-03$ \\
\hline MC45 11SN41_3.1 & 6.69 & 0.21 & & 6.895 & 0.27 & 2.5082 & 1.7898 & 1.4014 & $1.5959 \mathrm{E}-03$ \\
\hline MC45 11SN41_3.2 & 6.08 & 0.21 & & 6.283 & 0.26 & 2.5258 & 1.7785 & 1.4202 & $1.9173 \mathrm{E}-03$ \\
\hline MC45 91500 g2.2 & & & & 10.429 & 0.25 & 2.6214 & 1.8747 & 1.3983 & $1.5861 \mathrm{E}-03$ \\
\hline MC45 91500 g3.2 & & & & 10.243 & 0.20 & 2.6670 & 1.8834 & 1.4161 & $1.5532 \mathrm{E}-03$ \\
\hline MC45 91500 g4.2 & & & & 10.416 & 0.28 & 2.6668 & 1.8845 & 1.4151 & $1.5354 \mathrm{E}-03$ \\
\hline MC45 91500 g5.2 & & & & 10.229 & 0.26 & 2.6606 & 1.8840 & 1.4122 & $1.5401 \mathrm{E}-03$ \\
\hline average and $2 \mathrm{SD}$ & & & & 10.329 & 0.22 & & & & \\
\hline bracket average and 2SD & 10.07 & & 0.20221 & 10.274 & 0.21 & & & & \\
\hline MC45 11SN41_5.2 & 7.14 & 0.25 & & 7.462 & 0.20 & 2.6697 & 1.8824 & 1.4183 & $1.5950 \mathrm{E}-03$ \\
\hline MC45 11SN41_5.1 & 6.66 & 0.25 & & 6.984 & 0.28 & 2.6598 & 1.8800 & 1.4148 & $1.5583 \mathrm{E}-03$ \\
\hline MC45 11SN41_10.1 & 6.81 & 0.25 & & 7.134 & 0.26 & 2.6384 & 1.8751 & 1.4070 & $1.6416 \mathrm{E}-03$ \\
\hline MC45 11SN41_10.2 & 6.42 & 0.25 & & 6.742 & 0.22 & 2.6457 & 1.8724 & 1.4130 & $1.5445 \mathrm{E}-03$ \\
\hline MC45 11SN41_11.1 & 6.51 & 0.25 & & 6.836 & 0.18 & 2.6250 & 1.8666 & 1.4063 & $1.5813 \mathrm{E}-03$ \\
\hline MC45 11SN41_11.2 & 6.31 & 0.25 & & 6.630 & 0.22 & 2.6194 & 1.8638 & 1.4054 & $1.5466 \mathrm{E}-03$ \\
\hline MC45 CS03_6.1 & 6.29 & 0.25 & & 6.613 & 0.21 & 2.6099 & 1.8644 & 1.3998 & $1.6316 \mathrm{E}-03$ \\
\hline MC45 CS03_6.2 & 6.10 & 0.25 & & 6.425 & 0.24 & 2.6243 & 1.8615 & 1.4098 & $1.2939 \mathrm{E}-03$ \\
\hline
\end{tabular}




\begin{tabular}{|c|c|c|c|c|c|c|c|c|c|}
\hline Spot Number & $\begin{array}{l}\delta^{18} O \% \text { \% } \\
\text { VSMOW }\end{array}$ & $\begin{array}{l}\text { 2SD } \\
\text { (ext.) }\end{array}$ & $\begin{array}{l}\text { Mass Bias } \\
(\%)\end{array}$ & $\begin{array}{l}\delta^{18} O \% \text { \% } \\
\text { measured }\end{array}$ & $\begin{array}{l}\text { 2SE } \\
\text { (int.) }\end{array}$ & ${ }^{16} \mathrm{O}(\mathrm{Gcps})$ & IP (nA) & $\begin{array}{l}\text { Yield } \\
\text { (Gcps/nA) }\end{array}$ & ${ }^{16} \mathrm{OH} /{ }^{16} \mathrm{O}$ \\
\hline MC45 CS03_9.1 & 6.52 & 0.25 & & 6.846 & 0.23 & 2.6249 & 1.8523 & 1.4171 & $1.4534 \mathrm{E}-03$ \\
\hline MC45 CS03_5.1 & 6.57 & 0.25 & & 6.890 & 0.20 & 2.5970 & 1.8441 & 1.4083 & $3.0884 \mathrm{E}-03$ \\
\hline MC45 CS03_5.2 & 6.33 & 0.25 & & 6.654 & 0.28 & 2.5891 & 1.8388 & 1.4080 & $1.3258 \mathrm{E}-03$ \\
\hline MC45 CS03_3.1 & 6.68 & 0.25 & & 7.001 & 0.23 & 2.5658 & 1.8292 & 1.4027 & $1.3220 \mathrm{E}-03$ \\
\hline MC45 91500 g2.3 & & & & 10.495 & 0.23 & 2.5394 & 1.8169 & 1.3976 & $1.3072 \mathrm{E}-03$ \\
\hline MC45 $91500 \mathrm{~g} 3.3$ & & & & 10.489 & 0.19 & 2.5344 & 1.8063 & 1.4030 & $1.2974 \mathrm{E}-03$ \\
\hline MC45 $91500 \mathrm{~g} 4.3$ & & & & 10.284 & 0.29 & 2.5411 & 1.8347 & 1.3850 & $1.3367 \mathrm{E}-03$ \\
\hline MC45 91500 g5.3 & & & & 10.624 & 0.25 & 2.4931 & 1.7900 & 1.3928 & $1.3464 \mathrm{E}-03$ \\
\hline MC45 91500 g5.4 & & & & 10.408 & 0.23 & 2.4816 & 1.7765 & 1.3969 & $1.3780 \mathrm{E}-03$ \\
\hline average and 2SD & & & & 10.460 & 0.25 & & & & \\
\hline bracket average and $2 \mathrm{SD}$ & 10.07 & & 0.32139 & 10.395 & 0.25 & & & & \\
\hline MC45 CS03_2.1 & 6.70 & 0.37 & & 6.943 & 0.22 & 2.4705 & 1.7598 & 1.4039 & $1.5964 \mathrm{E}-03$ \\
\hline MC45 CS03_2.2 & 7.33 & 0.37 & & 7.574 & 0.18 & 2.4417 & 1.7471 & 1.3976 & $1.4575 \mathrm{E}-03$ \\
\hline MC45 CS01_8.1 & 5.89 & 0.37 & & 6.131 & 0.32 & 2.7133 & 1.8646 & 1.4551 & $1.4601 \mathrm{E}-03$ \\
\hline MC45 CS01_8.2 & 6.98 & 0.37 & & 7.228 & 0.33 & 2.6589 & 1.8757 & 1.4175 & $1.4558 \mathrm{E}-03$ \\
\hline MC45 CS01_5.1 & 5.51 & 0.37 & & 5.753 & 0.24 & 2.6687 & 1.8778 & 1.4212 & $1.4056 \mathrm{E}-03$ \\
\hline MC45 CS01_5.2 & 5.92 & 0.37 & & 6.165 & 0.23 & 2.6671 & 1.8783 & 1.4200 & $1.3971 \mathrm{E}-03$ \\
\hline MC45 CS01_3.2 & 5.69 & 0.37 & & 5.932 & 0.21 & 2.6683 & 1.8758 & 1.4225 & $1.4686 \mathrm{E}-03$ \\
\hline MC45 CS01_3.1 & 5.85 & 0.37 & & 6.089 & 0.36 & 2.6528 & 1.8750 & 1.4148 & $1.4202 \mathrm{E}-03$ \\
\hline MC45 CS01_1.2 & 7.78 & 0.37 & & 8.024 & 0.23 & 2.6532 & 1.8692 & 1.4195 & $1.5338 \mathrm{E}-03$ \\
\hline MC45 CS01_1.1 & 7.72 & 0.37 & & 7.965 & 0.21 & 2.6439 & 1.8666 & 1.4164 & $1.4651 \mathrm{E}-03$ \\
\hline MC45 CS10_1.1 & 6.26 & 0.37 & & 6.501 & 0.23 & 2.6180 & 1.8594 & 1.4080 & $4.0528 \mathrm{E}-03$ \\
\hline MC45 CS10_1.2 & 6.74 & 0.37 & & 6.983 & 0.25 & 2.6135 & 1.8549 & 1.4090 & $1.4645 \mathrm{E}-03$ \\
\hline MC45 91500 g2.4 & & & & 10.121 & 0.22 & 2.5975 & 1.8477 & 1.4058 & $1.4525 \mathrm{E}-03$ \\
\hline MC45 91500 g3.4 & & & & 10.132 & 0.17 & 2.5869 & 1.8404 & 1.4056 & $1.4627 \mathrm{E}-03$ \\
\hline MC45 $91500 \mathrm{~g} 4.4$ & & & & 10.160 & 0.26 & 2.5594 & 1.8315 & 1.3975 & $1.4843 \mathrm{E}-03$ \\
\hline
\end{tabular}




\begin{tabular}{|c|c|c|c|c|c|c|c|c|c|}
\hline Spot Number & $\begin{array}{l}\delta^{18} O \% \text { \% } \\
\text { VSMOW } \\
\end{array}$ & $\begin{array}{l}\text { 2SD } \\
(\text { ext. })\end{array}$ & $\begin{array}{l}\text { Mass Bias } \\
(\% \mathrm{o})\end{array}$ & $\begin{array}{l}\delta^{18} O \% \text { o } \\
\text { measured }\end{array}$ & $\begin{array}{l}\text { 2SE } \\
\text { (int.) }\end{array}$ & ${ }^{16} \mathrm{O}$ (Gcps) & IP $(\mathbf{n A})$ & $\begin{array}{l}\text { Yield } \\
(\text { Gcps/nA) }\end{array}$ & ${ }^{16} \mathrm{OH} /{ }^{16} \mathrm{O}$ \\
\hline MC45 91500 g5.5 & & & & 10.150 & 0.20 & 2.5525 & 1.8226 & 1.4005 & $1.5005 \mathrm{E}-03$ \\
\hline average and 2SD & & & & 10.141 & 0.04 & & & & \\
\hline bracket average and $2 \mathrm{SD}$ & 10.07 & & 0.24179 & 10.314 & 0.37 & & & & \\
\hline MC45 CS10_3.3 & 6.57 & 0.44 & & 6.833 & 0.23 & 2.5192 & 1.8051 & 1.3956 & $1.5427 \mathrm{E}-03$ \\
\hline MC45 CS10_3.2 & 6.57 & 0.44 & & 6.826 & 0.23 & 2.5064 & 1.7941 & 1.3971 & $1.5681 \mathrm{E}-03$ \\
\hline MC45 CS10_3.1 & 6.42 & 0.44 & & 6.681 & 0.23 & 2.4847 & 1.7816 & 1.3946 & $1.5624 \mathrm{E}-03$ \\
\hline MC45 CS10_6.2 & 6.88 & 0.44 & & 7.135 & 0.20 & 2.4552 & 1.7661 & 1.3902 & $1.5701 \mathrm{E}-03$ \\
\hline MC45 CS10_6.1 & 6.55 & 0.44 & & 6.804 & 0.26 & 2.4428 & 1.7564 & 1.3908 & $1.6206 \mathrm{E}-03$ \\
\hline MC45 CS10_10.1 & 6.70 & 0.44 & & 6.957 & 0.26 & 2.6508 & 1.8733 & 1.4150 & $1.5090 \mathrm{E}-03$ \\
\hline MC45 CS10_10.2 & 6.64 & 0.44 & & 6.897 & 0.25 & 2.6640 & 1.8822 & 1.4154 & $1.5455 \mathrm{E}-03$ \\
\hline MC45 CS13_7.1 & 6.92 & 0.44 & & 7.181 & 0.23 & 2.6641 & 1.8815 & 1.4159 & $1.5133 \mathrm{E}-03$ \\
\hline MC45 CS13_7.2 & 7.47 & 0.44 & & 7.732 & 0.20 & 2.6596 & 1.8811 & 1.4138 & $1.5061 \mathrm{E}-03$ \\
\hline MC45 CS13_6.1 & 7.64 & 0.44 & & 7.902 & 0.28 & 2.6588 & 1.8780 & 1.4158 & $1.5612 \mathrm{E}-03$ \\
\hline MC45 CS13_6.2 & 7.08 & 0.44 & & 7.344 & 0.21 & 2.6571 & 1.8762 & 1.4162 & $1.4911 \mathrm{E}-03$ \\
\hline MC45 CS13_5.1 & 7.65 & 0.44 & & 7.912 & 0.27 & 2.6463 & 1.8704 & 1.4148 & $1.5892 \mathrm{E}-03$ \\
\hline MC45 91500 g2.5 & & & & 10.307 & 0.22 & 2.6442 & 1.8644 & 1.4183 & $1.5081 \mathrm{E}-03$ \\
\hline MC45 91500 g3.5 & & & & 10.564 & 0.23 & 2.6160 & 1.8568 & 1.4089 & $1.5210 \mathrm{E}-03$ \\
\hline MC45 91500 g4.5 & & & & 10.506 & 0.28 & 2.6104 & 1.8483 & 1.4124 & $1.5123 \mathrm{E}-03$ \\
\hline MC45 91500 g5.6 & & & & 10.663 & 0.25 & 2.5900 & 1.8405 & 1.4072 & $1.5300 \mathrm{E}-03$ \\
\hline MC45 91500 g6.1 & & & & 10.555 & 0.22 & 2.5750 & 1.8326 & 1.4051 & $1.5441 \mathrm{E}-03$ \\
\hline average and 2SD & & & & 10.519 & 0.26 & & & & \\
\hline bracket average and $2 \mathrm{SD}$ & 10.07 & & 0.25728 & 10.330 & 0.44 & & & & \\
\hline MC45 CS13_5.2 & 7.34 & 0.50 & & 7.583 & 0.27 & 2.5591 & 1.8232 & 1.4036 & $1.5874 \mathrm{E}-03$ \\
\hline MC45 CS13_1.1 & 7.45 & 0.50 & & 7.696 & 0.28 & 2.5258 & 1.8078 & 1.3971 & $1.6558 \mathrm{E}-03$ \\
\hline MC45 CS13_1.2 & 7.11 & 0.50 & & 7.351 & 0.22 & 2.5177 & 1.7987 & 1.3997 & $1.5460 \mathrm{E}-03$ \\
\hline MC45 CS19_3.1 & 6.60 & 0.50 & & 6.842 & 0.24 & 2.4965 & 1.7842 & 1.3992 & $1.5784 \mathrm{E}-03$ \\
\hline
\end{tabular}




\begin{tabular}{|c|c|c|c|c|c|c|c|c|c|}
\hline Spot Number & $\begin{array}{l}\delta^{18} \mathrm{O} \% \\
\text { VSMOW } \\
\end{array}$ & $\begin{array}{l}\text { 2SD } \\
\text { (ext.) }\end{array}$ & $\begin{array}{l}\text { Mass Bias } \\
(\%)\end{array}$ & $\begin{array}{l}\delta^{18} \mathrm{O} \% \\
\text { measured }\end{array}$ & $\begin{array}{l}\text { 2SE } \\
\text { (int.) }\end{array}$ & ${ }^{16} \mathrm{O}$ (Gcps) & IP $(\mathbf{n A})$ & $\begin{array}{l}\text { Yield } \\
(\text { Gcps/nA })\end{array}$ & ${ }^{16} \mathrm{OH} /{ }^{16} \mathrm{O}$ \\
\hline MC45 CS19_3.2 & 5.91 & 0.50 & & 6.154 & 0.22 & 2.4802 & 1.7721 & 1.3996 & $1.5793 \mathrm{E}-03$ \\
\hline MC45 CS19_6.2 & 6.03 & 0.50 & & 6.268 & 0.20 & 2.6362 & 1.8825 & 1.4004 & $1.5566 \mathrm{E}-03$ \\
\hline MC45 CS19_6.1 & 5.39 & 0.50 & & 5.633 & 0.23 & 2.6822 & 1.8901 & 1.4190 & $1.6311 \mathrm{E}-03$ \\
\hline MC45 CS19_7.1 & 5.80 & 0.50 & & 6.044 & 0.25 & 2.6795 & 1.8913 & 1.4168 & $1.5386 \mathrm{E}-03$ \\
\hline MC45 CS19_7.2 & 5.32 & 0.50 & & 5.563 & 0.21 & 2.6788 & 1.8920 & 1.4158 & $1.6624 \mathrm{E}-03$ \\
\hline MC45 CS19_2.1 & 5.39 & 0.50 & & 5.630 & 0.22 & 2.6668 & 1.8881 & 1.4125 & 1.5849E-03 \\
\hline MC45 $91500 \mathrm{~g} 2.6$ & & & & 9.982 & 0.18 & 2.6778 & 1.8854 & 1.4203 & $1.5027 \mathrm{E}-03$ \\
\hline MC45 91500 g2.7 & & & & 10.051 & 0.19 & 2.6658 & 1.8830 & 1.4158 & $1.5138 \mathrm{E}-03$ \\
\hline MC45 $91500 \mathrm{~g} 3.6$ & & & & 10.216 & 0.22 & 2.6508 & 1.8771 & 1.4121 & $1.5183 \mathrm{E}-03$ \\
\hline MC45 $91500 \mathrm{~g} 3.7$ & & & & 10.263 & 0.18 & 2.6509 & 1.8717 & 1.4163 & $1.5225 \mathrm{E}-03$ \\
\hline MC45 $91500 \mathrm{~g} 4.6$ & & & & 10.015 & 0.28 & 2.6346 & 1.8645 & 1.4130 & $1.5313 \mathrm{E}-03$ \\
\hline average and $2 \mathrm{SD}$ & & & & 10.105 & 0.25 & & & & \\
\hline bracket average and $2 \mathrm{SD}$ & 10.07 & & 0.23979 & 10.312 & 0.50 & & & & \\
\hline MC45 CS10_9.1 & 6.84 & 0.30 & & 6.926 & 0.25 & 2.6114 & 1.8551 & 1.4077 & $1.5456 \mathrm{E}-03$ \\
\hline MC45 CS10_9.2 & 6.25 & 0.30 & & 6.338 & 0.23 & 2.6018 & 1.8500 & 1.4063 & $1.5250 \mathrm{E}-03$ \\
\hline MC45 $91500 \mathrm{~g} 2.8$ & & & & 10.164 & 0.16 & 2.5776 & 1.8416 & 1.3996 & $1.5211 \mathrm{E}-03$ \\
\hline MC45 91500 g5.7 & & & & 10.015 & 0.20 & 2.5686 & 1.8337 & 1.4008 & $1.5425 \mathrm{E}-03$ \\
\hline MC45 $91500 \mathrm{~g} 4.7$ & & & & 10.385 & 0.22 & 2.5542 & 1.8260 & 1.3988 & $1.5564 \mathrm{E}-03$ \\
\hline MC45 91500 g6.2 & & & & 10.338 & 0.23 & 2.5316 & 1.8153 & 1.3946 & $1.5554 \mathrm{E}-03$ \\
\hline average and 2SD & & & & 10.226 & 0.34 & & & & \\
\hline bracket average and $2 \mathrm{SD}$ & 10.07 & & 0.08789 & 10.159 & 0.30 & & & & \\
\hline MC45 91500 g2.9 & & & & 10.279 & 0.20 & 2.5751 & 1.8296 & 1.4075 & $9.6910 \mathrm{E}-04$ \\
\hline MC45 91500 g3.7 & & & & 10.422 & 0.22 & 2.5772 & 1.8298 & 1.4084 & 9.3527E-04 \\
\hline MC45 91500 g4.8 & & & & 10.420 & 0.26 & 2.5677 & 1.8307 & 1.4026 & $1.0059 \mathrm{E}-03$ \\
\hline MC45 91500 g5.8 & & & & 10.407 & 0.21 & 2.5706 & 1.8300 & 1.4046 & $1.0334 \mathrm{E}-03$ \\
\hline average and $2 \mathrm{SD}$ & & & & 10.382 & 0.14 & & & & \\
\hline
\end{tabular}




\begin{tabular}{|c|c|c|c|c|c|c|c|c|c|}
\hline Spot Number & $\begin{array}{l}\delta^{18} \mathrm{O} \% \text { } \\
\text { VSMOW } \\
\end{array}$ & $\begin{array}{l}\text { 2SD } \\
\text { (ext.) }\end{array}$ & $\begin{array}{l}\text { Mass Bias } \\
(\%)\end{array}$ & $\begin{array}{l}\delta^{18} \mathrm{O} \% \text { o } \\
\text { measured } \\
\end{array}$ & $\begin{array}{l}2 S E \\
\text { (int.) } \\
\end{array}$ & ${ }^{16} \mathrm{O}$ (Gcps) & IP (nA) & $\begin{array}{l}\text { Yield } \\
(\text { Gcps/nA) }\end{array}$ & ${ }^{16} \mathrm{OH} /{ }^{16} \mathrm{O}$ \\
\hline MC45 CS25_1.1 & 6.54 & 0.35 & & 6.735 & 0.24 & 2.5645 & 1.8289 & 1.4023 & $1.0941 \mathrm{E}-03$ \\
\hline MC45 CS25_1.2 & 6.41 & 0.35 & & 6.610 & 0.21 & 2.5661 & 1.8289 & 1.4031 & $1.0710 \mathrm{E}-03$ \\
\hline MC45 CS25_2.1 & 6.58 & 0.35 & & 6.776 & 0.24 & 2.5595 & 1.8263 & 1.4015 & 1.2039E-03 \\
\hline MC45 CS25_2.2 & 6.88 & 0.35 & & 7.081 & 0.21 & 2.5514 & 1.8235 & 1.3992 & $1.1013 \mathrm{E}-03$ \\
\hline MC45 CS25_3.1 & 5.31 & 0.35 & & 5.504 & 0.17 & 2.5435 & 1.8171 & 1.3998 & $1.2568 \mathrm{E}-03$ \\
\hline MC45 CS25_3.2 & 6.78 & 0.35 & & 6.980 & 0.19 & 2.5271 & 1.8110 & 1.3954 & 1.1419E-03 \\
\hline MC45 CS25_3.3 & 6.59 & 0.35 & & 6.787 & 0.23 & 2.5042 & 1.8040 & 1.3881 & 1.1972E-03 \\
\hline MC45 CS25_6.1 & 7.26 & 0.35 & & 7.455 & 0.22 & 2.4882 & 1.7926 & 1.3880 & $1.2187 \mathrm{E}-03$ \\
\hline MC45 CS25_6.2 & 7.33 & 0.35 & & 7.524 & 0.24 & 2.4717 & 1.7846 & 1.3850 & $1.1685 \mathrm{E}-03$ \\
\hline MC45 CS25_8.2 & 6.35 & 0.35 & & 6.551 & 0.24 & 2.4589 & 1.7722 & 1.3875 & $1.4351 \mathrm{E}-03$ \\
\hline MC45 CS25_8.1 & 6.78 & 0.35 & & 6.975 & 0.21 & 2.4430 & 1.7641 & 1.3848 & 1.2033E-03 \\
\hline MC45 91500 g2.10 & & & & 10.419 & 0.19 & 2.5521 & 1.8300 & 1.3946 & 1.1757E-03 \\
\hline MC45 91500 g3.8 & & & & 10.280 & 0.28 & 2.5759 & 1.8338 & 1.4047 & $1.1631 \mathrm{E}-03$ \\
\hline MC45 91500 g4.9 & & & & 10.033 & 0.19 & 2.5759 & 1.8345 & 1.4041 & $1.1639 \mathrm{E}-03$ \\
\hline MC45 91500 g4.10 & & & & 9.961 & 0.24 & 2.5645 & 1.8351 & 1.3975 & 1.1984E-03 \\
\hline MC45 91500 g5.9 & & & & 10.201 & 0.22 & 2.5853 & 1.8325 & 1.4108 & $1.1468 \mathrm{E}-03$ \\
\hline average and $2 \mathrm{SD}$ & & & & 10.179 & 0.37 & & & & \\
\hline bracket average and 2SD & 10.07 & & 0.19713 & 10.269 & 0.35 & & & & \\
\hline
\end{tabular}


APPENDIX G: Hf Isotope Data

\begin{tabular}{|c|c|c|c|c|c|c|c|c|c|c|c|c|}
\hline & ${ }^{176} \mathbf{L u} /{ }^{177} \mathbf{H f}$ & $2 \mathrm{SE}$ & ${ }^{176} \mathbf{Y b} /{ }^{177} \mathbf{H f}$ & $2 \mathrm{SE}$ & ${ }^{176} \mathbf{H f} /{ }^{177} \mathbf{H f}$ & $2 \mathrm{SE}$ & ${ }^{178} \mathbf{H f} /{ }^{177} \mathbf{H f}$ & $2 \mathrm{SE}$ & ${ }^{180} \mathbf{H f} /{ }^{177} \mathbf{H f}$ & $2 \mathrm{SE}$ & eHf & \pm 2 S.D. \\
\hline 11SN34_1 & 0.00209054 & 0.00014 & 0.06619485 & 0.0040 & 0.282791 & 0.000039 & 1.466567 & 0.00046 & 1.8864807 & 0.00014 & 2.2 & 1.4 \\
\hline 11SN34_2 & 0.00235868 & 0.00013 & 0.07090462 & 0.0059 & 0.282749 & 0.000049 & 1.466506 & 0.00043 & 1.8865361 & 0.00017 & 0.7 & 1.7 \\
\hline 11SN34_3 & 0.00104525 & 0.00008 & 0.03484118 & 0.0031 & 0.282737 & 0.000031 & 1.466679 & 0.00046 & 1.8866489 & 0.00011 & 0.3 & 1.1 \\
\hline 11SN34_4 & 0.00094388 & 0.00002 & 0.02877181 & 0.0003 & 0.282765 & 0.000037 & 1.466664 & 0.00043 & 1.8863605 & 0.00015 & 1.3 & 1.3 \\
\hline 11SN34_5 & 0.00129433 & 0.00007 & 0.04232991 & 0.0027 & 0.282761 & 0.000035 & 1.466680 & 0.00040 & 1.8867724 & 0.00012 & 1.2 & 1.2 \\
\hline 11SN34_6 & 0.00091806 & 0.00008 & 0.03028810 & 0.0028 & 0.282743 & 0.000042 & 1.466802 & 0.00053 & 1.8865915 & 0.00014 & 0.6 & 1.5 \\
\hline 11SN34_7 & 0.00119012 & 0.00010 & 0.03360653 & 0.0015 & 0.282694 & 0.000030 & 1.467449 & 0.00059 & 1.8866625 & 0.00012 & -1.2 & 1.1 \\
\hline 11SN34_8 & 0.00145805 & 0.00007 & 0.04738186 & 0.0029 & 0.282762 & 0.000037 & 1.466869 & 0.00045 & 1.8866256 & 0.00012 & 1.2 & 1.3 \\
\hline 11SN34_9 & 0.00176210 & 0.00016 & 0.05770327 & 0.0062 & 0.282785 & 0.000044 & 1.466872 & 0.00058 & 1.8866296 & 0.00014 & 2.0 & 1.6 \\
\hline 11SN36_1 & 0.00101038 & 0.00006 & 0.03501574 & 0.0025 & 0.282613 & 0.000032 & 1.466955 & 0.00042 & 1.8866259 & 0.00008 & -4.0 & 1.1 \\
\hline 11SN36_2 & Signal too low & & & & & & & & & & & \\
\hline 11SN36_3 & 0.00155962 & 0.00026 & 0.05112317 & 0.0103 & 0.282660 & 0.000039 & 1.467177 & 0.00067 & 1.8866234 & 0.00009 & -2.4 & 1.4 \\
\hline 11SN36_4 & 0.00105356 & 0.00006 & 0.03104408 & 0.0010 & 0.282686 & 0.000031 & 1.466927 & 0.00042 & 1.8866667 & 0.00008 & -1.4 & 1.1 \\
\hline 11SN36_5 & 0.00077660 & 0.00007 & 0.02449917 & 0.0020 & 0.282617 & 0.000029 & 1.466964 & 0.00045 & 1.8866056 & 0.00009 & -3.9 & 1.0 \\
\hline 11SN36_6 & 0.00056485 & 0.00005 & 0.01836948 & 0.0020 & 0.282536 & 0.000031 & 1.466986 & 0.00039 & 1.8866101 & 0.00008 & -6.7 & 1.1 \\
\hline 11SN36_7 & 0.00085110 & 0.00011 & 0.02714719 & 0.0036 & 0.282683 & 0.000024 & 1.466632 & 0.00046 & 1.8867378 & 0.00011 & -1.6 & 0.9 \\
\hline 11SN36_8 & 0.00063642 & 0.00005 & 0.01980438 & 0.0019 & 0.282637 & 0.000023 & 1.466914 & 0.00031 & 1.8866267 & 0.00008 & -3.2 & 0.8 \\
\hline 11SN36_9 & 0.00051902 & 0.00002 & 0.01530229 & 0.0006 & 0.282662 & 0.000026 & 1.466800 & 0.00039 & 1.8866367 & 0.00010 & -2.3 & 0.9 \\
\hline 11SN36_10 & 0.00048207 & 0.00002 & 0.01358899 & 0.0008 & 0.282682 & 0.000022 & 1.466965 & 0.00041 & 1.8867172 & 0.00007 & -1.5 & 0.8 \\
\hline 11SN37_1 & 0.00057706 & 0.00002 & 0.01634530 & 0.0008 & 0.282639 & 0.000029 & 1.466721 & 0.00040 & 1.8866689 & 0.00010 & -3.1 & 1.0 \\
\hline 11SN37_2 & 0.00071518 & 0.00002 & 0.02065061 & 0.0007 & 0.282654 & 0.000031 & 1.466884 & 0.00049 & 1.8866878 & 0.00010 & -2.6 & 1.1 \\
\hline 11SN37_3 & 0.00073965 & 0.00004 & 0.02014443 & 0.0005 & 0.282694 & 0.000032 & 1.466527 & 0.00042 & 1.8866530 & 0.00009 & -1.1 & 1.1 \\
\hline 11SN37_4 & 0.00094012 & 0.00003 & 0.02874178 & 0.0005 & 0.282675 & 0.000036 & 1.466856 & 0.00045 & 1.8867326 & 0.00009 & -1.8 & 1.3 \\
\hline 11SN37_5 & 0.00087085 & 0.00004 & 0.02685200 & 0.0019 & 0.282671 & 0.000028 & 1.466317 & 0.00051 & 1.8866551 & 0.00011 & -2.0 & 1.0 \\
\hline 11SN37_6 & 0.00046376 & 0.00004 & 0.01235644 & 0.0008 & 0.282639 & 0.000023 & 1.466769 & 0.00044 & 1.8866983 & 0.00007 & -3.1 & 0.8 \\
\hline 11SN37_7 & 0.00061654 & 0.00004 & 0.01738659 & 0.0011 & 0.282672 & 0.000025 & 1.466643 & 0.00039 & 1.8866706 & 0.00009 & -1.9 & 0.9 \\
\hline 11SN38_1 & 0.00098689 & 0.00004 & 0.03129659 & 0.0020 & 0.282596 & 0.000027 & 1.466732 & 0.00055 & 1.8866082 & 0.00011 & -4.6 & 1.0 \\
\hline 11SN38_2 & 0.00100295 & 0.00008 & 0.03206429 & 0.0030 & 0.282482 & 0.000032 & 1.466915 & 0.00039 & 1.8866244 & 0.00011 & -8.7 & 1.1 \\
\hline
\end{tabular}




\begin{tabular}{|c|c|c|c|c|c|c|c|c|c|c|c|c|}
\hline & ${ }^{176} \mathbf{L u} /{ }^{177} \mathbf{H f}$ & $2 \mathrm{SE}$ & ${ }^{176} \mathbf{Y b} /{ }^{177} \mathbf{H f}$ & $2 \mathrm{SE}$ & ${ }^{176} \mathrm{Hf} /{ }^{177} \mathrm{Hf}$ & $2 \mathrm{SE}$ & ${ }^{178} \mathbf{H f} /{ }^{177} \mathbf{H f}$ & $2 \mathrm{SE}$ & ${ }^{180} \mathrm{Hf} /{ }^{177} \mathrm{Hf}$ & $2 \mathrm{SE}$ & EHf & \pm 2 S.D. \\
\hline 11SN38_3 & 0.00058350 & 0.00001 & 0.01816974 & 0.0008 & 0.282685 & 0.000032 & 1.466677 & 0.00043 & 1.8866449 & 0.00011 & -1.5 & 1.1 \\
\hline 11SN38_4 & 0.00061984 & 0.00008 & 0.01780851 & 0.0023 & 0.282672 & 0.000036 & 1.466979 & 0.00064 & 1.8867211 & 0.00010 & -1.9 & 1.3 \\
\hline 11SN38_5 & 0.00106513 & 0.00012 & 0.03610033 & 0.0053 & 0.282617 & 0.000041 & 1.467025 & 0.00048 & 1.8866649 & 0.00012 & -3.9 & 1.5 \\
\hline 11SN38_6 & 0.00130712 & 0.00008 & 0.04404528 & 0.0027 & 0.282684 & 0.000034 & 1.466727 & 0.00063 & 1.8866785 & 0.00008 & -1.5 & 1.2 \\
\hline 11SN38_7 & 0.00050607 & 0.00000 & 0.01533556 & 0.0004 & 0.282636 & 0.000032 & 1.466888 & 0.00050 & 1.8867310 & 0.00011 & -3.2 & 1.1 \\
\hline 11SN38_8 & 0.00131495 & 0.00018 & 0.04072089 & 0.0064 & 0.282670 & 0.000039 & 1.466794 & 0.00051 & 1.8866483 & 0.00010 & -2.1 & 1.4 \\
\hline 11SN40_1 & 0.00072438 & 0.00005 & 0.02900454 & 0.0016 & 0.282632 & 0.000025 & 1.466990 & 0.00057 & 1.8866720 & 0.00012 & -3.4 & 0.9 \\
\hline 11SN40_2 & 0.00084780 & 0.00002 & 0.03540700 & 0.0011 & 0.282589 & 0.000035 & 1.467145 & 0.00044 & 1.8866539 & 0.00015 & -4.9 & 1.2 \\
\hline 11SN40_3 & 0.00128059 & 0.00015 & 0.05670152 & 0.0082 & 0.282636 & 0.000038 & 1.466429 & 0.00090 & 1.8865505 & 0.00019 & -3.2 & 1.3 \\
\hline 11SN40_4 & 0.00114325 & 0.00004 & 0.04797225 & 0.0025 & 0.282569 & 0.000034 & 1.466807 & 0.00095 & 1.8866193 & 0.00019 & -5.6 & 1.2 \\
\hline 11SN40_5 & 0.00123476 & 0.00009 & 0.05332453 & 0.0033 & 0.282650 & 0.000044 & 1.466989 & 0.00062 & 1.8866028 & 0.00017 & -2.7 & 1.6 \\
\hline 11SN40_6 & 0.00072540 & 0.00002 & 0.02883700 & 0.0007 & 0.282514 & 0.000033 & 1.466803 & 0.00070 & 1.8865435 & 0.00018 & -7.5 & 1.2 \\
\hline 11SN40_7* & 0.00349019 & 0.00013 & 0.14810154 & 0.0083 & 0.282585 & 0.000038 & 1.466905 & 0.00064 & 1.8868284 & 0.00015 & -5.2 & 1.3 \\
\hline 11SN40_8 & 0.00061332 & 0.00001 & 0.02573489 & 0.0010 & 0.282490 & 0.000030 & 1.466833 & 0.00075 & 1.8866247 & 0.00017 & -8.4 & 1.1 \\
\hline 11SN40_9 & 0.00057164 & 0.00004 & 0.02413598 & 0.0008 & 0.282522 & 0.000026 & 1.466946 & 0.00062 & 1.8866772 & 0.00014 & -7.2 & 0.9 \\
\hline 11SN40_10 & 0.00071716 & 0.00004 & 0.02767787 & 0.0011 & 0.282533 & 0.000031 & 1.466789 & 0.00043 & 1.8866557 & 0.00009 & -6.8 & 1.1 \\
\hline 11SN41_1 & 0.00068167 & 0.00008 & 0.03463110 & 0.0040 & 0.282521 & 0.000032 & 1.466652 & 0.00059 & 1.8866106 & 0.00014 & -7.3 & 1.1 \\
\hline 11SN41_2 & 0.00061023 & 0.00003 & 0.02836695 & 0.0020 & 0.282609 & 0.000029 & 1.466933 & 0.00043 & 1.8867267 & 0.00013 & -4.2 & 1.0 \\
\hline 11SN41_3 & 0.00115724 & 0.00014 & 0.06446100 & 0.0070 & 0.282670 & 0.000053 & 1.466911 & 0.00062 & 1.8866830 & 0.00019 & -2.0 & 1.9 \\
\hline 11SN41_4 & 0.00081866 & 0.00004 & 0.04503055 & 0.0018 & 0.282501 & 0.000034 & 1.466902 & 0.00055 & 1.8866311 & 0.00017 & -8.0 & 1.2 \\
\hline 11SN41_5 & 0.00086514 & 0.00005 & 0.04317502 & 0.0019 & 0.282601 & 0.000021 & 1.466929 & 0.00043 & 1.8867183 & 0.00013 & -4.5 & 0.7 \\
\hline 11SN41_6 & 0.00054994 & 0.00001 & 0.02804554 & 0.0004 & 0.282600 & 0.000027 & 1.466962 & 0.00050 & 1.8867914 & 0.00012 & -4.5 & 1.0 \\
\hline 11SN41_7 & 0.00137556 & 0.00003 & 0.06913091 & 0.0025 & 0.282595 & 0.000028 & 1.467120 & 0.00041 & 1.8868143 & 0.00011 & -4.7 & 1.0 \\
\hline 11SN41_8 & 0.00137138 & 0.00003 & 0.06885116 & 0.0025 & 0.282601 & 0.000030 & 1.467100 & 0.00040 & 1.8868010 & 0.00011 & -4.5 & 1.1 \\
\hline CSO1_1* & 0.00214023 & 0.00019 & 0.11841764 & 0.0106 & 0.282747 & 0.000027 & 1.466895 & 0.00065 & 1.8866070 & 0.00015 & 0.6 & 0.9 \\
\hline CSO1_2* & 0.00213178 & 0.00008 & 0.11560884 & 0.0037 & 0.282755 & 0.000044 & 1.466999 & 0.00070 & 1.8866991 & 0.00019 & 0.9 & 1.6 \\
\hline CSO1_3 & 0.00174095 & 0.00007 & 0.08203896 & 0.0058 & 0.282777 & 0.000044 & 1.466501 & 0.00066 & 1.8866836 & 0.00017 & 1.7 & 1.6 \\
\hline CS01_4 & 0.00146322 & 0.00006 & 0.07633048 & 0.0051 & 0.282781 & 0.000026 & 1.466665 & 0.00058 & 1.8867039 & 0.00013 & 1.9 & 0.9 \\
\hline CS01_5* & 0.00282409 & 0.00048 & 0.12529583 & 0.0139 & 0.282541 & 0.000086 & 1.465739 & 0.00098 & 1.8865286 & 0.00022 & -6.7 & 3.0 \\
\hline CS01_6 & 0.00142326 & 0.00009 & 0.07250614 & 0.0034 & 0.282654 & 0.000032 & 1.466851 & 0.00055 & 1.8865927 & 0.00014 & -2.6 & 1.1 \\
\hline CS01_7* & 0.00203452 & 0.00005 & 0.11541118 & 0.0038 & 0.282722 & 0.000037 & 1.467623 & 0.00231 & 1.8870029 & 0.00038 & -0.2 & 1.3 \\
\hline
\end{tabular}




\begin{tabular}{|c|c|c|c|c|c|c|c|c|c|c|c|c|}
\hline & ${ }^{176} \mathbf{L u} /{ }^{177} \mathbf{H f}$ & $2 \mathrm{SE}$ & ${ }^{176} \mathbf{Y b} /{ }^{177} \mathbf{H f}$ & $2 \mathrm{SE}$ & ${ }^{176} \mathrm{Hf} /{ }^{177} \mathbf{H f}$ & $2 \mathrm{SE}$ & ${ }^{178} \mathbf{H f} /{ }^{177} \mathbf{H f}$ & $2 \mathrm{SE}$ & ${ }^{180} \mathrm{Hf} /{ }^{177} \mathrm{Hf}$ & $2 \mathrm{SE}$ & EHf & \pm 2 S.D. \\
\hline CS03_1 & 0.00096897 & 0.00010 & 0.05464807 & 0.0086 & 0.282619 & 0.000059 & 1.467198 & 0.00118 & 1.8868504 & 0.00030 & -3.8 & 2.1 \\
\hline CS03_2 & 0.00097640 & 0.00003 & 0.05072849 & 0.0011 & 0.282562 & 0.000044 & 1.467116 & 0.00076 & 1.8869583 & 0.00021 & -5.8 & 1.6 \\
\hline $\mathrm{CS} 03 \_3$ & 0.00059109 & 0.00001 & 0.02965206 & 0.0009 & 0.282686 & 0.000032 & 1.466822 & 0.00041 & 1.8867834 & 0.00012 & -1.4 & 1.1 \\
\hline $\mathrm{CS} 03$ _4 & 0.00093239 & 0.00005 & 0.05138531 & 0.0025 & 0.282667 & 0.000044 & 1.466974 & 0.00055 & 1.8867619 & 0.00014 & -2.1 & 1.5 \\
\hline CSO3_5 & 0.00076667 & 0.00004 & 0.04025235 & 0.0035 & 0.282609 & 0.000039 & 1.466990 & 0.00085 & 1.8867066 & 0.00019 & -4.2 & 1.4 \\
\hline CS03_6 & 0.00059251 & 0.00005 & 0.03051345 & 0.0033 & 0.282760 & 0.000039 & 1.466456 & 0.00099 & 1.8867198 & 0.00022 & 1.2 & 1.4 \\
\hline $\mathrm{CS} 03 \_7$ & 0.00096855 & 0.00011 & 0.05276175 & 0.0058 & 0.282581 & 0.000036 & 1.466741 & 0.00048 & 1.8867340 & 0.00016 & -5.2 & 1.3 \\
\hline CSO3_8 & 0.00075148 & 0.00002 & 0.03614928 & 0.0023 & 0.282564 & 0.000028 & 1.466965 & 0.00064 & 1.8867347 & 0.00014 & -5.8 & 1.0 \\
\hline CS03_9 & 0.00101116 & 0.00014 & 0.05561938 & 0.0103 & 0.282705 & 0.000041 & 1.466288 & 0.00075 & 1.8863941 & 0.00021 & -0.8 & 1.5 \\
\hline CS07_1 & 0.00178977 & 0.00006 & 0.06306065 & 0.0027 & 0.282536 & 0.000035 & 1.467074 & 0.00049 & 1.8865393 & 0.00013 & -6.8 & 1.2 \\
\hline CSO7_2 & 0.00097985 & 0.00001 & 0.03213915 & 0.0011 & 0.282710 & 0.000030 & 1.466949 & 0.00045 & 1.8865901 & 0.00009 & -0.6 & 1.0 \\
\hline CSO7_3 & 0.00096926 & 0.00003 & 0.03243939 & 0.0004 & 0.282682 & 0.000039 & 1.466817 & 0.00050 & 1.8865897 & 0.00014 & -1.6 & 1.4 \\
\hline CS07_4 & 0.00077705 & 0.00001 & 0.02636454 & 0.0008 & 0.282700 & 0.000027 & 1.466890 & 0.00036 & 1.8866309 & 0.00010 & -1.0 & 0.9 \\
\hline CS07_5 & 0.00051719 & 0.00002 & 0.01850386 & 0.0011 & 0.282572 & 0.000027 & 1.466893 & 0.00048 & 1.8864709 & 0.00010 & -5.5 & 1.0 \\
\hline CS07_6 & 0.00034658 & 0.00001 & 0.01161454 & 0.0005 & 0.282581 & 0.000025 & 1.466739 & 0.00050 & 1.8864760 & 0.00013 & -5.1 & 0.9 \\
\hline CS07_7 & 0.00121954 & 0.00023 & 0.04205869 & 0.0080 & 0.282752 & 0.000031 & 1.466653 & 0.00056 & 1.8865430 & 0.00013 & 0.9 & 1.1 \\
\hline CS07_8 & 0.00098132 & 0.00001 & 0.03454277 & 0.0011 & 0.282724 & 0.000028 & 1.466907 & 0.00044 & 1.8865896 & 0.00010 & -0.1 & 1.0 \\
\hline CS10_1 & 0.00079118 & 0.00003 & 0.03689723 & 0.0020 & 0.282699 & 0.000049 & 1.466745 & 0.00074 & 1.8865795 & 0.00013 & -1.0 & 1.7 \\
\hline CS10_2 & 0.00042503 & 0.00001 & 0.02012635 & 0.0004 & 0.282688 & 0.000037 & 1.466752 & 0.00071 & 1.8867584 & 0.00017 & -1.3 & 1.3 \\
\hline CS10_3 & 0.00072884 & 0.00004 & 0.03263044 & 0.0020 & 0.282686 & 0.000034 & 1.466927 & 0.00051 & 1.8866208 & 0.00014 & -1.4 & 1.2 \\
\hline $\mathrm{CS} 10 \_4$ & 0.00070070 & 0.00005 & 0.03076914 & 0.0014 & 0.282614 & 0.000039 & 1.467226 & 0.00064 & 1.8868566 & 0.00014 & -4.0 & 1.4 \\
\hline CS10_5 & 0.00049570 & 0.00004 & 0.02559826 & 0.0017 & 0.282617 & 0.000044 & 1.466599 & 0.00074 & 1.8866180 & 0.00012 & -3.8 & 1.6 \\
\hline CS10_6 & 0.00072806 & 0.00002 & 0.03702864 & 0.0017 & 0.282670 & 0.000048 & 1.466918 & 0.00065 & 1.8867846 & 0.00012 & -2.0 & 1.7 \\
\hline CS10_7 & 0.00050587 & 0.00002 & 0.02421964 & 0.0009 & 0.282686 & 0.000038 & 1.466871 & 0.00058 & 1.8866480 & 0.00015 & -1.4 & 1.4 \\
\hline CS10_8 & 0.00062824 & 0.00002 & 0.02767219 & 0.0014 & 0.282655 & 0.000040 & 1.467240 & 0.00053 & 1.8867411 & 0.00012 & -2.5 & 1.4 \\
\hline CS10_9 & 0.00085777 & 0.00009 & 0.03632042 & 0.0023 & 0.282651 & 0.000046 & 1.466134 & 0.00068 & 1.8865322 & 0.00019 & -2.7 & 1.6 \\
\hline CS10_10 & 0.00078440 & 0.00005 & 0.03453287 & 0.0018 & 0.282603 & 0.000043 & 1.466605 & 0.00057 & 1.8867483 & 0.00015 & -4.4 & 1.5 \\
\hline CS13_1 & 0.00076284 & 0.00005 & 0.03580041 & 0.0016 & 0.282643 & 0.000031 & 1.466985 & 0.00060 & 1.8867321 & 0.00013 & -3.0 & 1.1 \\
\hline CS13_2 & 0.00105495 & 0.00018 & 0.05646955 & 0.0095 & 0.282580 & 0.000044 & 1.467084 & 0.00049 & 1.8867955 & 0.00014 & -5.2 & 1.6 \\
\hline CS13_3 & 0.00079296 & 0.00002 & 0.03990526 & 0.0008 & 0.282518 & 0.000027 & 1.467095 & 0.00039 & 1.8867930 & 0.00012 & -7.4 & 1.0 \\
\hline $\mathrm{CS} 13 \_4$ & 0.00080337 & 0.00006 & 0.04109339 & 0.0048 & 0.282564 & 0.000037 & 1.466403 & 0.00055 & 1.8864855 & 0.00014 & -5.8 & 1.3 \\
\hline
\end{tabular}




\begin{tabular}{|c|c|c|c|c|c|c|c|c|c|c|c|c|}
\hline & ${ }^{176} \mathbf{L u} /{ }^{177} \mathbf{H f}$ & $2 \mathrm{SE}$ & ${ }^{176} \mathbf{Y b} /{ }^{177} \mathbf{H f}$ & $2 \mathrm{SE}$ & ${ }^{176} \mathbf{H f} /{ }^{177} \mathbf{H f}$ & $2 \mathrm{SE}$ & ${ }^{178} \mathbf{H f} /{ }^{177} \mathbf{H f}$ & $2 \mathrm{SE}$ & ${ }^{180} \mathrm{Hf} /{ }^{177} \mathrm{Hf}$ & $2 \mathrm{SE}$ & $\varepsilon \mathbf{H f}$ & \pm 2 S.D. \\
\hline CS13_5 & 0.00063200 & 0.00005 & 0.03213649 & 0.0017 & 0.282497 & 0.000039 & 1.466823 & 0.00047 & 1.8865685 & 0.00014 & -8.1 & 1.4 \\
\hline CS13_6 & 0.00108422 & 0.00015 & 0.06143983 & 0.0096 & 0.282851 & 0.000046 & 1.467115 & 0.00065 & 1.8866441 & 0.00015 & 4.4 & 1.6 \\
\hline CS13_7 & 0.00174686 & 0.00011 & 0.09496655 & 0.0059 & 0.282813 & 0.000050 & 1.467086 & 0.00048 & 1.8867504 & 0.00013 & 3.0 & 1.8 \\
\hline CS13_8 & 0.00090273 & 0.00007 & 0.05012273 & 0.0065 & 0.282665 & 0.000032 & 1.467007 & 0.00048 & 1.8866587 & 0.00014 & -2.2 & 1.1 \\
\hline CS13_9 & 0.00078210 & 0.00001 & 0.04055734 & 0.0008 & 0.282711 & 0.000032 & 1.466995 & 0.00044 & 1.8866923 & 0.00013 & -0.6 & 1.1 \\
\hline CS19_1* & 0.00350874 & 0.00031 & 0.16758988 & 0.0175 & 0.282819 & 0.000044 & 1.467096 & 0.00041 & 1.8869147 & 0.00018 & 3.1 & 1.6 \\
\hline CS19_2 & 0.00176716 & 0.00035 & 0.08040453 & 0.0151 & 0.282829 & 0.000051 & 1.467068 & 0.00042 & 1.8868904 & 0.00015 & 3.6 & 1.8 \\
\hline CS19_3 & Signal & low & & & & & & & & & & \\
\hline CS19_4 & 0.00089056 & 0.00007 & 0.04592467 & 0.0056 & 0.282788 & 0.000061 & 1.466410 & 0.00078 & 1.8864496 & 0.00019 & 2.2 & 2.1 \\
\hline CS19_5 & 0.00083918 & 0.00008 & 0.03845303 & 0.0039 & 0.282829 & 0.000069 & 1.466090 & 0.00086 & 1.8867424 & 0.00014 & 3.6 & 2.5 \\
\hline CS19_6* & 0.00262568 & 0.00036 & 0.12685881 & 0.0099 & 0.282930 & 0.000074 & 1.465873 & 0.00077 & 1.8865257 & 0.00020 & 7.1 & 2.6 \\
\hline CS19_7 & 0.00155409 & 0.00019 & 0.06781250 & 0.0076 & 0.282865 & 0.000053 & 1.465885 & 0.00072 & 1.8865482 & 0.00021 & 4.9 & 1.9 \\
\hline CS19_8 & 0.00078413 & 0.00008 & 0.03679749 & 0.0047 & 0.282967 & 0.000073 & 1.465533 & 0.00132 & 1.8863884 & 0.00027 & 8.5 & 2.6 \\
\hline CS19_9 & 0.00120137 & 0.00014 & 0.05572465 & 0.0062 & 0.282827 & 0.000067 & 1.465590 & 0.00096 & 1.8862665 & 0.00027 & 3.5 & 2.4 \\
\hline CS19_10 & 0.00589984 & 0.00070 & 0.30442071 & 0.0377 & 0.282895 & 0.000075 & 1.466978 & 0.00046 & 1.8866825 & 0.00017 & 5.6 & 2.7 \\
\hline CS25_1 & 0.00078535 & 0.00002 & 0.04041696 & 0.0011 & 0.282795 & 0.000029 & 1.466847 & 0.00080 & 1.8866205 & 0.00020 & 2.4 & 1.0 \\
\hline $\mathrm{CS} 25 \_2$ & 0.00123916 & 0.00007 & 0.06765347 & 0.0054 & 0.282682 & 0.000041 & 1.466891 & 0.00044 & 1.8867313 & 0.00014 & -1.6 & 1.4 \\
\hline CS25_3 & 0.00093830 & 0.00005 & 0.05123919 & 0.0041 & 0.282544 & 0.000029 & 1.467081 & 0.00043 & 1.8867462 & 0.00011 & -6.5 & 1.0 \\
\hline CS25_4 & 0.00083706 & 0.00004 & 0.04481190 & 0.0028 & 0.282673 & 0.000030 & 1.466665 & 0.00041 & 1.8867013 & 0.00014 & -1.9 & 1.1 \\
\hline CS25_5 & 0.00070641 & 0.00003 & 0.03103071 & 0.0008 & 0.282667 & 0.000036 & 1.466694 & 0.00055 & 1.8864709 & 0.00018 & -2.1 & 1.3 \\
\hline CS25_6 & 0.00105738 & 0.00008 & 0.05909455 & 0.0049 & 0.282733 & 0.000039 & 1.466862 & 0.00053 & 1.8866863 & 0.00013 & 0.2 & 1.4 \\
\hline CS25_7 & 0.00105277 & 0.00012 & 0.05592242 & 0.0059 & 0.282680 & 0.000039 & 1.466982 & 0.00052 & 1.8867014 & 0.00017 & -1.7 & 1.4 \\
\hline $\mathrm{CS} 25 \_8$ & 0.00105581 & 0.00004 & 0.05480857 & 0.0014 & 0.282596 & 0.000032 & 1.466752 & 0.00044 & 1.8866141 & 0.00013 & -4.6 & 1.1 \\
\hline CS25_9 & 0.00061966 & 0.00001 & 0.03046001 & 0.0009 & 0.282708 & 0.000026 & 1.466820 & 0.00052 & 1.8867270 & 0.00013 & -0.7 & 0.9 \\
\hline
\end{tabular}

${ }^{*}{ }^{176} \mathrm{Yb} /{ }^{177} \mathrm{Hf}>0.1$, analysis not included in results 
APPENDIX H: Mixing Model Parameters

\begin{tabular}{|c|c|c|c|c|c|c|c|c|c|c|}
\hline & \multicolumn{2}{|c|}{ DM*-Ptz ${ }^{+} \mathbf{I}$} & \multicolumn{2}{|c|}{ DM*-Ptz ${ }^{+}$II } & \multicolumn{2}{|c|}{ DM*-Pln** } & \multicolumn{2}{|c|}{$\mathbf{E M}^{\#}-\mathbf{P t z}^{+}$} & \multicolumn{2}{|c|}{ EM ${ }^{\#}-\mathbf{P l n} * *$} \\
\hline $\begin{array}{l}\text { Mantle Melt } \\
\text { Fraction }\end{array}$ & $\varepsilon \mathrm{Hf}$ & $\delta^{18} \mathrm{O}$ & $\varepsilon \mathrm{Hf}$ & $\delta^{18} \mathrm{O}$ & $\varepsilon \mathrm{Hf}$ & $\delta^{18} \mathrm{O}$ & $\varepsilon \mathrm{Hf}$ & $\delta^{18} \mathrm{O}$ & $\varepsilon \mathrm{Hf}$ & $\delta^{18} \mathrm{O}$ \\
\hline 0 & -22.0 & 11.5 & -30.0 & 11.5 & 10.0 & 11.5 & 10.0 & 11.5 & -30.0 & 8.5 \\
\hline 0.2 & -16.9 & 10.3 & -26.7 & 10.3 & 10.6 & 10.3 & 8.9 & 10.3 & -23.7 & 7.9 \\
\hline 0.4 & -10.9 & 9.0 & -22.5 & 9.0 & 11.2 & 9.0 & 7.5 & 9.0 & -16.5 & 7.2 \\
\hline 0.6 & -4.0 & 7.8 & -17.1 & 7.8 & 12.0 & 7.8 & 5.7 & 7.8 & -8.0 & 6.6 \\
\hline 0.8 & 4.2 & 6.5 & -10.0 & 6.5 & 12.9 & 6.5 & 3.3 & 6.5 & 2.0 & 5.9 \\
\hline 1 & 14.0 & 5.3 & 0.0 & 5.3 & 14.0 & 5.3 & 0.0 & 5.3 & 14.0 & 5.3 \\
\hline
\end{tabular}

* Depleted Mantle was calculated with the following parameters: $\delta^{18} \mathrm{O}=5.3 \%$ (Valley et al., 2003), $\varepsilon \mathrm{Hf}=+14$ (Lackey et al., 2012; Nelson et al., 2013), Hf = 4 ppm (Beard \& Johnson, 1997)

\# Enriched Mantle was calculated with the following parameters: $\delta^{18} \mathrm{O}=5.3 \%$ (Valley et al., 2003), $\varepsilon \mathrm{Hf}=0.0$ (Beard \& Johnson, 1997), Hf = 3 ppm (Beard \& Johnson, 1997; Omerod et al., 1991).

${ }^{+}$Proterozoic Crust was calculated using the following parameters: $\delta^{18} \mathrm{O}=8.5$ to $11.5 \%$ o (Lackey et al., 2012 ), $\varepsilon \mathrm{Hf}=-22$ to -30 (Goodge \& Vervoort, 2006; Lackey et al., 2012), Hf = 6 ppm (Taylor \& McLennan, 1995).

** Panthalassan crust was calculated using the following parameters: $\delta^{18} \mathrm{O}=10$ to $12 \%$ (Lackey et al., 2012 ), $\varepsilon \mathrm{Hf}=+9$ to +12 (Lackey et al., 2012), Hf = 6 ppm (Taylor \& McLennan, 1995). 